
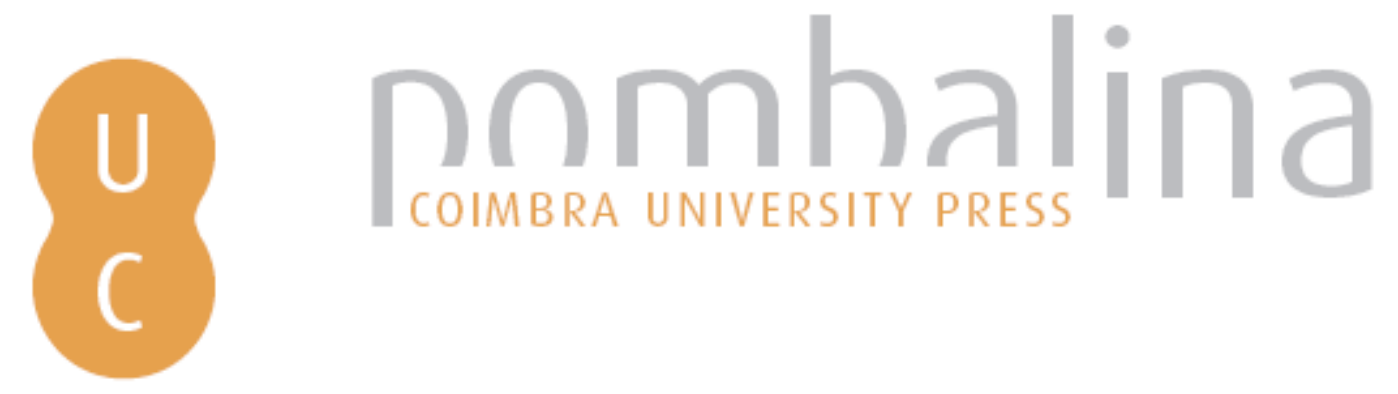

\title{
A retórica e a construção da cidade na Idade Média e no Renascimento: homo eloquens homo politicus
}

\begin{tabular}{|c|c|}
\hline Autor(es): & $\begin{array}{l}\text { Soares, Nair Castro, coord.; Urbano, Carlota Miranda, coord.; Miranda, } \\
\text { Margarida, coord. }\end{array}$ \\
\hline Publicado por: & $\begin{array}{l}\text { Centro de Estudos Clássicos e Humanísticos; Imprensa da Universidade } \\
\text { de Coimbra }\end{array}$ \\
\hline $\begin{array}{l}\text { URL } \\
\text { persistente: }\end{array}$ & URI:http://hdl.handle.net/10316.2/2399 \\
\hline DOI: & DOI:http://dx.doi.org/10.14195/978-989-8281-98-2 \\
\hline Accessed : & 26-Apr-2023 12:56:28 \\
\hline
\end{tabular}

A navegação consulta e descarregamento dos títulos inseridos nas Bibliotecas Digitais UC Digitalis, UC Pombalina e UC Impactum, pressupõem a aceitação plena e sem reservas dos Termos e Condições de Uso destas Bibliotecas Digitais, disponíveis em https://digitalis.uc.pt/pt-pt/termos.

Conforme exposto nos referidos Termos e Condições de Uso, o descarregamento de títulos de acesso restrito requer uma licença válida de autorização devendo o utilizador aceder ao(s) documento(s) a partir de um endereço de IP da instituição detentora da supramencionada licença.

Ao utilizador é apenas permitido o descarregamento para uso pessoal, pelo que o emprego do(s) título(s) descarregado(s) para outro fim, designadamente comercial, carece de autorização do respetivo autor ou editor da obra.

Na medida em que todas as obras da UC Digitalis se encontram protegidas pelo Código do Direito de Autor e Direitos Conexos e demais legislação aplicável, toda a cópia, parcial ou total, deste documento, nos casos em que é legalmente admitida, deverá conter ou fazer-se acompanhar por este aviso.

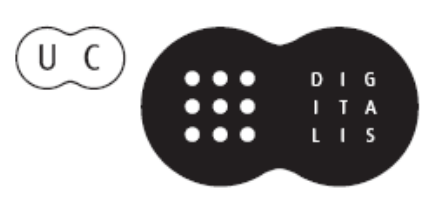


Colecção Autores Gregos e Latinos SérIe Ensaios

\section{Nair Castro Soares Margarida Miranda Carlota Miranda Urbano}

(Coord.)

HOMO ELOQVENS HOMO POLITICVS

\section{A Retórica e a CONSTRUÇÃo dA CIDAdE NA IdAdE MÉdia E NO RENASCIMENTO}




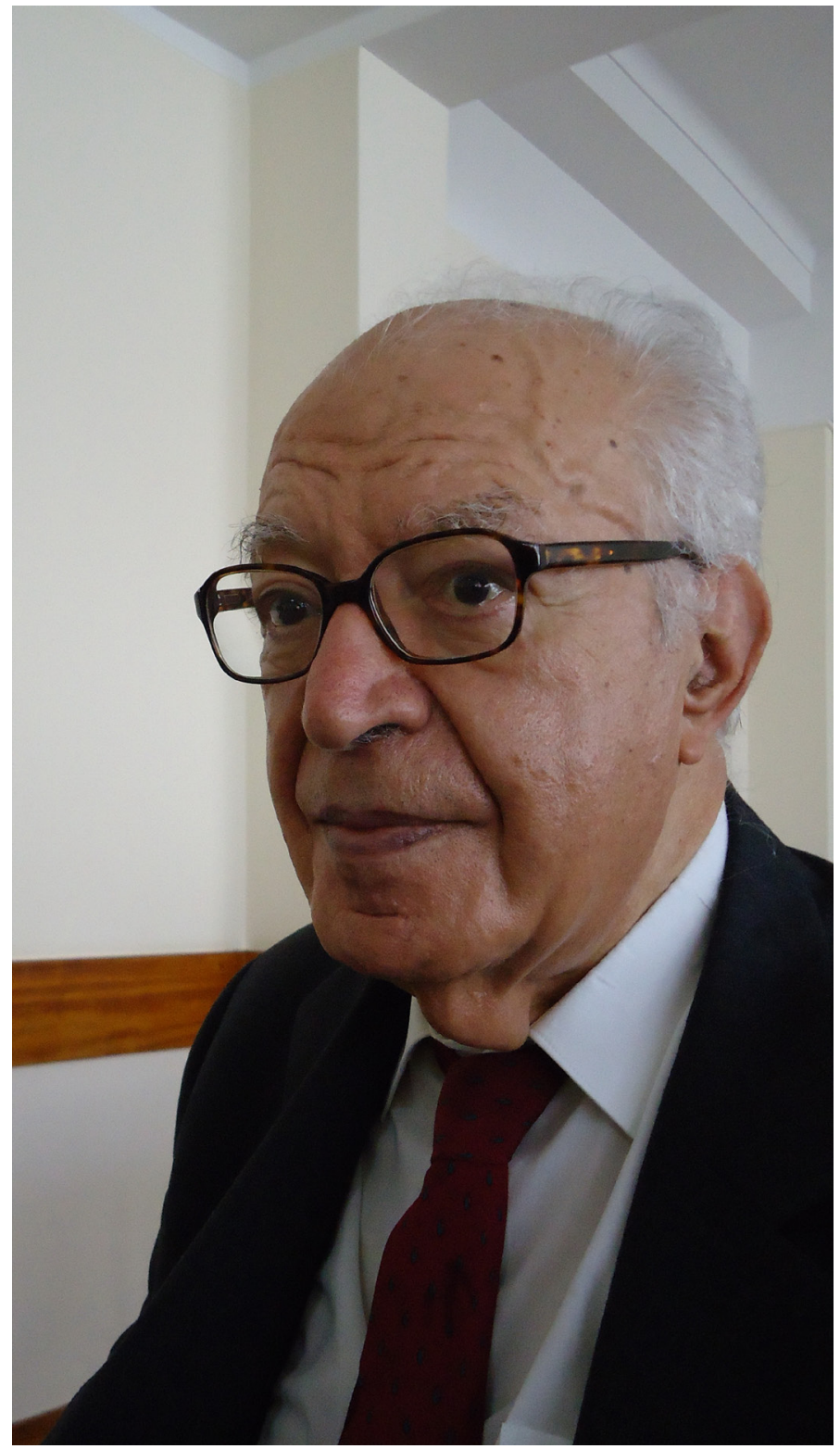




\author{
Nair Castro Soares \\ Universidade de Coimbra \\ Margarida Miranda \\ Universidade de Coimbra \\ Carlota Miranda Urbano \\ Universidade de Coimbra
}

(Coord.)

\title{
Homo eloquens homo politicus
}

\section{A retórica e a construção da cidade na Idade Média e no Renascimento}


Todos os volumes desta série são sujeitos a arbitragem científica independente.

Coordenação: Nair Castro Soares, Margarida Miranda, Carlota Miranda Urbano

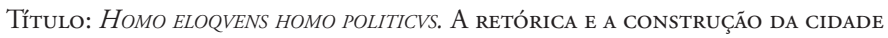
na Idade Média e no Renascimento

Editor: Centro de Estudos Clássicos e Humanísticos IMPRENSA DA UNIVERSIDADE DE COIMBRA

EDIÇÃo: 1a/2011

Coordenador Científico do Plano de Edição: Maria do Céu Fialho

Conselho editorial: José Ribeiro Ferreira, Maria de Fátima Silva,

Francisco de Oliveira, Nair Castro Soares

Director técnico da colecçấo: Delfim F. Leẫo

Concepção gráfica e paginação: Rodolfo Lopes, Nelson Henrique

ObRA REALIZADA No ÂMBITO DAS ACTIVIDADES DA UI\&D

Centro de Estudos Clássicos e Humanísticos

Universidade de Coimbra

FACULDADE DE LeTRAS

TEL.: 239859981 | FAX: 239836733

3000-530 CoImbra

ISBN: 978-989-8281-97-5

ISBN DigitAL: 978-989-8281-98-2

Depósito Legal: 334521/11

DOI: http://dx.doi.org/10.14195/978-989-8281-98-2

Obra Publicada com o Apoio de:

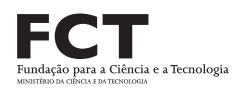

$\mathrm{POCI} / 2010$

(C) Imprensa da Universidade de Coimbra

(C) Classica Digitalia Vniversitatis Conimbrigensis (http://classicadigitalia.uc.pt)

(C) Centro de Estudos Clássicos e Humanísticos da Universidade de Coimbra

Reservados todos os direitos. Nos termos legais fica expressamente proibida a reprodução total ou parcial por qualquer meio, em papel ou em edição electrónica, sem autorização expressa dos titulares dos direitos. É desde já excepcionada a utilização em circuitos académicos fechados para apoio a leccionação ou extensão cultural por via de e-learning. 


\section{ÍNDICE}

PórTICO

RENASCIMENTOS DA ARTE RETÓRICA E GLOBALIZAÇÃO

Belmiro Fernandes Pereira (Universidade do Porto)

Discursos DisTinTOS PARA CONCEPÇÓES DIFERENTES DA FÉ CRISTÁ

António Manuel Ribeiro Rebelo (Universidade de Coimbra)

Proyección política y pedagógica del Prólogo a la Rethórica de Cicerón dedicado por Alfonso de Cartagena al Infante D. DUARTE

Tomás González Rolán (Universidad Complutense de Madrid)

Anexo I - MANUSCRITO DE EL ESCORIAL, SIGNATURA: T. II. 12

Retórica e RES PUbLICA no Renascimento. Da eloquênCia NASCEU A CIDADE

Maria Margarida Lopes de Miranda (Universidade de Coimbra)

A HISTÓRIA OPVS ORATORIVM E "ESPERTADOR DO ENTENDIMENTO"

Nair Castro Soares (Universidade de Coimbra)

Na Correspondência de Erasmo:

O HUMANISTA, AS LETRAS E A CIDADE

Jorge Alves Osório (Universidade do Porto)

André de Resende e a RELATINIZAÇÃo ortográfica da língua PORTUGUESA

Sebastiáo Tavares de Pinho (Universidade de Coimbra)

Anexo II - (PRIMEIRA PÁgINA DA FALA DE ANDRÉ DE RESENDE À PRINCESA D. JOANA)

André de Resende e Jerónimo de Azambuja:

Da INTERPRETAÇÃo dos TEXTOS MOSAICOS

Virgínia Soares Pereira (Universidade do Minho)

Anexo III - (CARTA DE ANDRÉ DE RESENDE AO CARDEAL D.

HENRIQUE) 
Poesia, hagiografia e Política antes da Restauração de 1640247 Carlota Maria Lopes de Miranda Urbano (Universidade de Coimbra)

Do HUMANISTA COMO FASCÍNIO AO FASCÍNIO DO HUMANISTA 273 Carlos Ascenso André (Universidade de Coimbra) 
A Américo da Costa Ramalho Magistro dilectissimo 


\section{CARPENT TVA POMA NEPOTES}

Em 1945 sai a lume o Catálogo dos Manuscritos da Biblioteca Geral da Universidade de Coimbra, relativos à Antiguidade Clássica.

Segundo declara o Prof. Costa Ramalho, foi a leitura directa dos manuscritos, por ele sumariados nesta obra, que despertou o seu interesse pelo Latim Renascentista. Era então aluno da Faculdade de Letras da Universidade de Coimbra.

Já antes, contudo, numa aula da disciplina de História dos Descobrimentos, regida pelo grande historiador Damiáo Peres, teve a feliz oportunidade de lhe ser dado observar o documento latino em que se apoiava a fixação do momento da morte de Diogo Cão. A correcta tradução do discípulo, que punha em causa este marco histórico, foi aceite pelo eminente professor, que numa lição admirável de sabedoria e exemplo, facultou ao então aluno do $2^{\circ}$ ano de Filologia Clássica, Américo da Costa Ramalho, a possibilidade de publicar o resultado da sua arguta observação, no número 2 da Revista Portuguesa de História (Coimbra, 1943). Foi este o seu primeiro trabalho de Latim Renascentista.

A atenção criteriosa ao facto histórico, veiculado pelos textos latinos, a par da correcçáo de erros decorrentes de traduçóes que distorcem o sentido desses 
mesmos textos - que tantas vezes se repetem em estudos de conceituados autores - , tornou-se dominante em todo o percurso da investigação do Prof. Costa Ramalho.

O seu conhecimento do Latim e do Latim Renascentista, na sua especificidade, revelado na profícua investigação individual, foi cedo posto ao serviço dos discípulos que desde 1952 orientou em teses de licenciatura, mestrado e doutoramento. Numerosos são os trabalhos que saíram dos seus seminários - a já designada "Escola de Latim de Coimbra" - que mereceram ser publicados nas últimas décadas.

No $8^{\circ}$ Congresso Brasileiro de Língua e Literatura (Rio de Janeiro, Julho de 1976) Américo da Costa Ramalho explicava assim os seus interesses científicos e pedagógicos:

"Naturalmente, depois do Latim Medieval e do Latim Cristão, era de esperar que chegasse a vez do Latim Renascentista para objecto de estudo [...] Resolvemos em Coimbra concentrar a nossa atençáo sobre a Literatura e Cultura Portuguesas, expressas em latim. O primeiro requisito indispensável é um bom domínio do latim clássico e uma boa cultura greco-latina. O conhecimento do grego, naturalmente, ajuda.

Quando as nossas dissertaçóes de licenciatura dactilografadas começaram a aparecer nas bibliotecas Central da Faculdade e do Instituto de Estudos Clássicos, verificamos que quem mais as procurava eram estudiosos de Cultura Portuguesa, desprovidos hoje de um conveniente conhecimento do latim.

Quanto a nós, porém, aquilo que mais satisfação nos dá é ver o entusiasmo que os estudantes póem em ler e 
interpretar textos que são realmente desconhecidos e para os quais não há a muleta das traduçôes em línguas modernas, como para os clássicos greco-latinos. E o sentirem que o seu trabalho é útil e traz sempre alguma novidade ao estudo da Cultura Portuguesa, além do progresso que lhes proporciona no conhecimento do latim literário.”

A estes trabalhos se devem em grande parte o conhecimento deste período da cultura europeia e o envolvimento cultural português nas grandes correntes de pensamento e nos ideais estéticos que marcaram e definiram as coordenadas do movimento Humanista.

Absorvido pela aventura ultramarina, o Portugal de quinhentos franqueia as portas ao Humanismo vindo de Itália, não mais tarde que a Espanha ou a França. E não raro, os nossos humanistas ombrearam com os grandes vultos das letras europeias, como é o caso de André de Resende, Damião de Góis e D. Jerónimo Osório. Ou se impuseram além fronteiras, quer no exílio, judeus errantes, como Diogo Pires, ou ao serviço da cúria romana como Aquiles Estaço e D. Miguel da Silva, o dedicatário de Il Cortegiano de Baldassare Castglione, que vem a lume em 1528.

Honor alit artes, afirma Cícero nas Tusculanas. Assim o considera também o homo faber do nosso Renascimento que transforma a antinomia arma/toga em binómio harmonioso de pensamento e acção, em ideal de plena realização humana. Soldados e homens de letras, de que Camóes é paradigma admirável, impóem ao humanismo português um cunho verdadeiramente lusíada. 
As obras que o Prof. Costa Ramalho dedicou a este século de ouro da nossa história, em que o saber e as letras são muitas vezes postos ao serviço da grandeza pátria, são disso prova. Refiram-se os livros Estudos sobre a Época do Renascimento, Estudos sobre o século XVI, Estudos Camonianos, Camóes, o seu tempo e o nosso, Latim Renascentista, os quatro volumes Para a História do Humanismo em Portugal e as Epistolas de Cataldo, em dois tomos. Sem esquecer ainda a tradução comentada do Dialogus do Jesuíta Duarte de Sande sobre a Embaixada de quatro príncipes japoneses à Europa, em 1585, documento muito curioso da vida académica, social e política do século XVI. Esta obra mereceu o prémio de História Calouste Gulbenkian, "Presença de Portugal no mundo".

O conhecimento profundo que tem da época do Renascimento, dos seus horizontes culturais, das fontes clássicas predilectas dos diferentes autores, veiculadas através do ensino, do magistério docente e das múltiplas ediçóes que os prelos europeus divulgam, permite ao Prof. Costa Ramalho apontar intertextualidades, reminiscências, alusões literárias, loci communes.

E surgem assim semeadas ao longo dos seus diversos estudos, referências que denunciam a recepção dos clássicos e a forma original como são assimilados e transfigurados numa nova entidade discursiva, de acordo com os padróes estéticos e as correntes de sensibilidade da época. É que nem só os escritores quinhentistas em latim ocuparam os interesses do Mestre, mas também a produção literária em vernáculo, desde Gil Vicente e 
Camôes aos recentiores como Garrett, Camilo, Fernando Pessoa, manifestando-se na diversidade temática e na perenidade dos motivos clássicos um verdadeiro elo de ligaçáo e de unidade entre todos os estudos.

Saudemos, pois, o Mestre e a sua obra, que se impóe pelo rigor da análise, pela oportunidade dos seus themata, pelo seu valor para a história da cultura e da literatura em Portugal, de que ainda os vindouros hãode colher os frutos, na expressão virgiliana: Carpent tua poma nepotes.

\author{
Nair Castro Soares \\ Margarida Miranda \\ Carlota Miranda Urbano
}




\section{Pórtico}

\section{Homo eloquens homo politicus}

\section{A retórica e a construçáo da cidade na Idade Média e no Renascimento}

O desenvolvimento das cidades nos séculos XII e XIII traz consigo o aparecimento dos intelectuais. À renovação das cidades veio acrescentar-se portanto uma outra renovação - a renovação cultural, cujos protagonistas são professores, sábios, escritores, homens cuja profissão é essencialmente ler, escrever ou ensinar. Esses intelectuais, só é possível encontrá-los, diz Jacques Le Goff, com as cidades!

Com o advento do Humanismo, porém, uma nova cultura é inaugurada, em que o homo sapiens se torna indissociável do homo eloquens e do homo politicus. Ideologia subjacente a todos os tratados humanísticos de pedagogia é o reconhecimento de sólidos laços entre eloquência e vida política, assim como a importância do novo curriculum emergente (os studia humanitatis) para o desenvolvimento da cultura, para a formaçáo do carácter e a preparação para a vida cívica.

Efectivamente, à Cidade e à constituição dos laços sociais estão directamente associados os studia humanitatis, que resultam de uma cultura da 
sociabilidade, assente sobre as artes intelectuais ou ingenuae (também chamadas humaniores), próprias do homem livre. De entre os studia humanitatis ganham especial relevo os estudos de Retórica, não a Retórica reduzida ao puro exercício técnico e formal, mas uma Retórica que, sendo tão inseparável da dialéctica quanto da realidade, é entendida como instrumento prático e útil, nos domínios político, jurídico, religioso, moral e pedagógico. A Retórica fez então do indivíduo não apenas o homo sapiens mas também o homo eloquens, apto para a intervenção na vida cívica à qual estava destinado, ou seja, apto para vir a ser homo politicus.

O conjunto dos estudos que apresentamos neste volume reflecte esses nexos entre homo sapiens, homo eloquens e homo politicus e as suas múltiplas expressóes, em Portugal e na Europa.

Nair Castro Soares

Margarida Miranda Carlota Miranda Urbano 


\section{Renascimentos da Arte Retórica e Globalização}

Belmiro Fernandes Pereira 
Se a retórica, com a revolução romântica, entrou em descrédito, rejeitada em nome de uma pretensa espontaneidade e sinceridade poéticas, se os estudos retóricos foram, depois, perdendo importância, sobretudo nas escolas da Europa continental, tal facto não significou, como muitos pensaram e alguns desejaram, a morte de uma arte transmitida ao longo de mais de vinte e cinco séculos, nem a sua exclusão, pelas forças criadoras do génio, para o limbo das coisas inúteis ${ }^{1}$. Exemplo paradigmático éo caso de Henri-Irénée

${ }^{1} \mathrm{Na}$ Literatura Portuguesa uma das vozes que se ergueram contra o normativismo estéril da "Arte infeliz, rhetorica chamada" foi Nicolau Tolentino, poeta que a contragosto se viu «mestre de meninos»; da retórica escreve: "Ensino as tuas leis, mas não as creio:/ Ou nunca ergueste fogo em peito alheio, / Ou tu já hoje estás degenerada». Em sentido contrário, porém, se pronunciou Camilo: «o extermínio da Retórica foi uma calamidade para os que pretendem comover. A gente, dantes, conhecia umas figuras de eloquência que puxavam aritmeticamente um certo número de lágrimas das coisas, lacrimae rerum, aos olhos das pessoas. Se a glândula do líquido sentimento não se abria ao toque da metáfora, era seguro fender-se golpeada pela penetrante hipérbole. Hoje em dia já se não chora senão com uma oftalmia” (Camilo 1903, 2a ed.: 54-55). Em boa verdade, a generalização das proclamaçóes anti-retóricas é anterior ao romantismo pois é possível documentá-la desde finais do séc. XVI. Como observou Fumaroli, os clássicos franceses, de Montaigne a La Fontaine, parecem unânimes no desprezo por la rhétorique (vejam-se os ensaios de Montaigne «Sur la vanité des paroles», "Contre Cicéron», ou a fábula de La Fontaine «Le charlatan»). No entanto, hoje, estuda-se com afinco a retórica destes autores, pois La Fontaine, por exemplo, não só 
Marrou que teve de fazer a sua palinódia na Retractatio que acrescentou à reedição de Saint Agustin et la fin de la culture antique (1937):

"Je ne puis relire sans rougir le chapitre que j'ai consacré à la rhétorique chez Saint Agustin et notamment à la dispositio. 'Saint Agustin compose mal' (p. 61): jugement d'un jeune barbare ignorant et présomptueux. Depuis que la rhétorique antique a cessé d'être enseignée dans nos écoles, les intellectuels français ne connaissent plus cette technique fondamentale et notre communion avec les classiques en est bien diminuée, sinon compromise ».

Ao contrário do que se poderia supor, foi a retórica, em tempos de fascínio pela utilidade imediata dos saberes e técnicas, de entre as artes da palavra, aquela que veio a revelar-se o instrumento mais necessário e eficaz nas sociedades que, ao longo do séc. XX, sofreram e beneficiaram dos efeitos da aceleraçáo histórica. Com efeito, se a comunicação, no passado, era naturalmente limitada pelo espaço - do tribunal, da assembleia, da igreja, da praça pública -, por não haver maneira de propagar mais além a voz humana, no nosso tempo, instrumentos e técnicas cada vez mais aperfeiçoadas permitiram dar à palavra força incoercível e eficácia inaudita.

É verdade que há muito o homem vencera as barreiras do tempo, por meio da escrita, e lograra a propagação do discurso através do livro impresso: a retórica constitui-se como arte na Grécia do séc. V

tomava fábulas da Retórica aristotélica (2. 20), como recomendava o estudo diuturno de Quintiliano (Fumaroli 1986 : 33-51). 
a. C., quando se expande o conhecimento e uso da escrita; a retórica renasce na Itália do Quattrocento, quando beneficia das possibilidades oferecidas pelo invento de Guttenberg; com a imprensa, a retórica pôde transformar-se em retórica literária. Mas esse era um tempo diferido, que alterava as condiçóes da situação comunicacional, e quando, em diferentes momentos e por razóes várias, a retórica é reduzida a técnica de análise e composição, perde a sua dinâmica; padecendo de letteraturazione, deleita, talvez ensine, deixa porém de impelir à acção: a distância entre orador e ouvinte dificulta o ofício de persuadir. Esse foi o tempo da retórica senza microfono.

O século passado viu nascer a comunicação de massas, a difusão do discurso, escrito e oral, à escala planetária, mercê de poderosos meios de amplificação da voz humana; o meio frio da galáxia de Guttenberg, rapidamente substituído pelos canais quentes da era de McLuhan; mas viu também como tamanho poder perverte a verdadeira comunicação; na pólis deste nosso tempo, saturado de discurso e informação, de novo manda a palavra por limitada que seja a isegoria (Calboli 1983: 23-56 e Verdelho 1986: 139-156).

$\mathrm{Na}$ Europa a recuperação da retórica processou-se sobretudo a dois níveis, no plano filosófico e no campo dos estudos linguísticos e literários. A filosofia há muito tempo que excomungara a retórica; Descartes e Kant prolongaram a seu modo a atitude anti-retórica que desde Platão marcava o pensamento filosófico. A reabilitação da retórica neste domínio inicia-se em 1952 , 
quando Chaim Perelman e Olbrechts-Tyteca publicam uma colectânea de artigos sob o título Rhétorique et Philosophie; aí proclamam o seu propósito de estudar «les moyens d'argumentation, autres que ceux relevant de la logique formelle, qui permettent d'obtenir ou d'accroître l'adhésion d'autrui aux thèses qu'on propose à son assentiment» (Lempereur 1990: 117)². Em 1958 sistematizam essa teoria no Traité de l'argumentation que apresentam como nouvelle rhétorique. Para resolver o velho dissídio entre retórica e filosofia, Perelman regressa à tradição clássica elegendo como texto fundacional a Retórica de Aristóteles ${ }^{3}$.

As proposiçôes filosóficas não se impóem pela sua evidência, dependem da argumentação, já que, como distinguiam os antigos, persuadir é mais que convencer: se a convicção provém da razão, a persuasão emprega meios irracionais que geram a força que conduz à acção; importa, pois, investigar os recursos que permitem ganhar a adesão do leitor ou ouvinte, definido não como um ser lógico mas como um ser sugestionável. Perelman não pretende apenas reabilitar a retórica enquanto disciplina e teoria da argumentação, ambiciona mais, quer estabelecê-la como regina scientiarum (Cohen 1994: 69-82). Partindo do tratado aristotélico propóe uma nova retórica que exclui dos seus interesses implicaçóes

${ }^{2}$ A introdução ao opus magnum de Perelman e Olbrechts-Tyteca, «Nouvelle Rhétorique: Logique et Rhétorique», constitui o cap. 5 do volume em que Lempereur colige trabalhos das figuras mais marcantes de três geraçóes da Escola de Bruxelas: Eugène Dupréel (1879-1967), Chaïm Perelman (1912-1984) e Michel Meyer.

${ }^{3}$ Sobre esta questão vd. Ijsseling, S. 1976. 
psicológicas e estéticas; alarga a noção de auditório, identificado com o ouvinte universal, redefine o género epidíctico centrando-o no juízo de valor, sobreleva as noçóes, reelaboradas a partir da teoria clássica, de auditório, ouvinte, acordo e consenso. Perelman assinala os condicionamentos pragmáticos da demonstração que tem de ser sempre comunicada e aceite. A nova retórica apresenta-se, por conseguinte, como uma metodologia que legitima decisóes e comportamentos e que tem nas ciências humanas, na religião e na filosofia, na moral e no direito, o seu campo de aplicação (Manassero 1994: 288-293).

Perelman interessava-se pela lógica jurídica e especializara-se nas teorias de Frege; Tyteca tinha formação na área da sociologia, psicologia social e economia política. Não eram, portanto, classicistas, nem sequer filósofos profissionais, mas, por diferentes vias, convergiram numa conclusão: a lógica formal não se revelava particularmente eficaz na análise das componentes emotivas e irracionais do discurso político; assim, procurando esclarecer o uso racional de elementos estranhos à lógica formal, chegaram à retórica clássica e, naturalmente, à Rhetorica e aos Topica de Aristóteles. Perelman sempre preferiu definir a retórica como a arte de bem falar de modo persuasivo, estudo dos métodos que permitem agir sobre o auditório para obter a sua adesão e alcançar o consenso, definição que está na raiz do conflito entre filósofos e retores, entre um ideal contemplativo e um método educativo destinado 
a formar cidadãos comprometidos com a pólis ${ }^{4}$. Como o conhecimento da verdade absoluta está fora do tempo e não produz necessariamente a acção justa, importa voltar às partes do Organon que tratam do elogio e da reprovação, do justo e do injusto, do oportuno e do inoportuno, em suma, dos procedimentos indispensáveis para enfrentar os problemas práticos que relevam para o mundo dos valores. Perelman rejeita, por conseguinte, o racionalismo matemático de Seiscentos mas, igualmente, o irracionalismo romântico, afirmando a função essencial da linguagem como instrumento de comunicação filosófica. Considerando o íntimo nexo que une res e uerba, consciente do facto de que qualquer acto linguístico obriga a tomar partido, a escolher um certo ponto de vista, a nouvelle rhétorique adquire uma consciência clara e positiva do valor específico das técnicas retóricas, mormente no campo do discurso ético, jurídico e político que implica sempre uma decisão em matéria axiológica (Vasoli 1975:15-36).

Mais interessante ainda se nos antolha, até por constituir um aspecto relativamente descurado da sua obra, a recuperação da arte oratória feita mais recentemente por um profundo conhecedor da retórica

${ }^{4}$ A noção de método, popularizada por Ramée e pelo ramismo, era corrente entre os humanistas do Renascimento. A retórica mostra a sua utilidade como uia, como método de disciplina intelectual; Marc-Antoine Muret, Tomé Correia ou os mestres jesuítas não se cansam de frisar as vantagens desta arte enquanto método racional, uia ac ratio, que permite encontrar os meios mais adequados para persuadir a multidão (no dizer do humanista português que ensinou retórica em Roma e Bolonha, methodus cuiuslibet rei docendae). 
grega, Hans-Georg Gadamer, filósofo e classicista que em textos publicados em 1967 e 1976 mostrou até que ponto a arte da persuasão subjaz à sua arte de compreender e de tornar compreensível (Gadamer 1994, 2a ed.) $)^{5}$ É preciso insistir hoje, adverte Gadamer, que a racionalidade da argumentação retórica - que, recorrendo aos afectos, reivindica fundamentalmente os argumentos e trabalha com probabilidades - é e continuará a ser um factor condicionante da sociedade muito mais poderoso que a certeza da ciência (Gadamer 1994, 2a ed.: 394).

No campo dos estudos linguísticos e literários, o eclipse da retórica foi mais aparente que real. As doutrinas prescritas nas cinco partes canónicas da arte perviveram, em diferentes graus, desde logo na história literária, embora esta se tenha constituído no clima positivista do fim do séc. XIX, «avec un fort indice polémique à l'égard de la rhétorique, considerée comme l'empire des grands choses vagues dont les études savantes devaient se délivrer» (Fumaroli 1987-88: 417-434) . Se a revolução romântica, com Victor Hugo e Taine,

${ }^{5} \mathrm{O}$ próprio autor confessa essa dívida na sua autobiografia filosófica: «Comencé así un nuevo estudio planificado de la filosofía clásica (bajo la guía de Paul Friedländer), con atención preferente además de a los filósofos griegos, sobre todo a Píndaro, iluminado por el ya entonces accesible Hölderlin... y a la retórica, cuya función complementaria de la filosofía presentí entonces y que me ha acompañado hasta la elaboración de mi hermenéutica filosófica» (Gadamer 1994, 2a ed.: 382).

${ }^{6}$ Gustave Lanson (1902) proclama a recusa da retórica e a sua substituição pelo estudo histórico das obras literárias: história literária e nacionalismo de mãos dadas, segundo o modelo da Geistesgeschichte alemã. 
recusa a estética clássica, em nome do entusiasmo e da inspiração, rejeitando a aliança entre retórica e filosofia, em favor de um rigoroso e presumido cientismo, manifesta simultaneamente uma paixão paradoxal pela poesia nocturna e pela ciência iluminadora que afastaria as trevas do obscurantismo. Ora, por estranho que pareça, essa poética do génio retoma em $\mathrm{V}$. Hugo ideias essenciais do De oratore ciceroniano e, contra todas as expectativas, é na natureza retórica do historicismo de Taine que Lanson encontrará a tábua de salvação da pedagogia literária, quando se interromper o ensino oficial da retórica (Fumaroli 1979: 363-373) ${ }^{7}$. Por isso, a partir do romantismo, os tratados de retórica clássica são substituídos por retóricas literárias que, para frisar a sua novidade, passam a denominar-se estética, poética, crítica.

A recuperação da retórica como disciplina literária virá prolongar uma tendência muito antiga: reduzida à elocutio, a retórica será revalorizada enquanto estilística ou ciência da expressividade. Esta 'redução tropológica', proveniente do ramismo quinhentista e ilustrada no séc. XVIII nos tratados de Dumarsais e Fontanier, perdura no séc. $\mathrm{XX}$ no formalismo russo e nas teorias

${ }^{7}$ A estética romântica radica nas noçóes de ingenium e iudicium da retórica antiga; race, milieu, moment, conceitos essenciais na teoria de Taine, traduzem as ideias de natura, opinio/mores e tempora. Por isso, escreve Marc Fumaroli (1979 : 363-373), «l'histoire littéraire, telle que la conçoit Lanson, n'est pas seulement une science, au sens germanique: c'est aussi et surtout un substitut de l'ancienne rhétorique, une psychagogie de la sensibilité littéraire, fondée sur l'admiration et la connaissance intime des chefs-d'oeuvre». Vd. também G. Genette (1969). 
do grupo $\mu$ de Liège. A linguística e a teoria literária apropriam-se da tradição, restringindo a retórica à elocutio, ao estudo das figuras, circunscrito por vezes à metáfora e à metonímia. Por essa razão reclama Gerard Genette o rejuvenescimento da retórica, sugerindo, como ponto de partida, o ensaio de Roland Barthes, a famosa Aide Mémoire em que o autor considera o conhecimento da retórica clássica alicerce indispensável da moderna semiótica. Com efeito, Barthes, nesse texto - modesto e datado, mas, sem dúvida, importante pelo efeito que produziu no espaço francófono e francófilo -, tinha proclamado: «le monde est incroyablement plein d'ancienne Rhétorique». Mas, enredado na ganga da época, Barthes não augura qualquer futuro à retórica; admitindo apenas a necessidade de elaborar a história do seu passado glorioso, conclui com uma frase que os últimos trinta anos se encarregaram de desmentir: "( ) ni une technique, ni une esthétique, ni une morale de la Rhétorique ne sont plus possibles, mais une histoire? Oui, une histoire de la Rhétorique (comme recherche, comme livre, comme enseignement) est aujourd'hui nécessaire, élargie par une nouvelle manière de penser (linguistique, sémiologie, science historique, psychanalyse, marxisme)»(Barthes 1970: 172-229) .

${ }^{8}$ Lamenta o autor a inexistência de uma história ou manual de retórica, por modesto que seja. Por sentir a falta de um compêndio de retórica antiga, redigiu essa aide-mémoire como propedêutica pessoal. A descrição do sistema retórico que oferece é útil, mas simplista e padece das limitaçóes que decorrem do desconhecimento da extensa bibliografia que já então existia para a história da retórica; por outro lado, se o esforço é bem intencionado, não deixa de incorrer em preconceitos, nem evita uma certa arrogância: 
A verdade, porém, é que o ostracismo a que a retórica foi votada não foi geral; em alguns países continuou a ser ensinada de forma sistemática e noutros renasceu com enorme fulgor. Assim sucedeu na América do Norte com a criação de Departments of Speech em muitas universidades e a proliferação de manuais e cursos de rhetoric and composition, destinados a responder às necessidades de um novo estilo de vida, guias que ensinam de repente a bem falar, dirigir reunióes, manter conversas mundanas e a escrever cartas formais ou de amor. $\mathrm{O}$ desenvolvimento dos meios de comunicação, a mobilidade de uma sociedade que valoriza o mérito pessoal, o peso cada vez maior da publicidade e do consumo vieram demonstrar as vantagens práticas da preparação retórica.

A redescoberta da retórica no pós-guerra tornou evidentes os vínculos que a unem à crítica literária, à política e ao direito, revelou o seu interesse para a filosofia e a teologia e até o contributo que pode oferecer às ciências naturais e às tecnologias, tanto na discussão das formas mais adequadas de comunicar com a opiniáo pública, como na reflexão nunca concluída sobre a responsabilidade social da ciência (Classen 1988). Por outro lado, o crescente interesse pela história da retórica permitiu avaliar melhor em que medida esta arte marcou a Cultura do Ocidente, não só na literatura, mas também nas artes plásticas, na pintura e na música.

a morte da retórica é dado assente, a retórica, pseudo-ciência, perde na comparação com as novas ciências da linguagem. 
Assim, na esteira de R. Volkmann (Die Rhetorik der Griechen und Römer in systematischer Übersicht, 1885) e E. Norden (Die Antike Kunstprosa, 1898) aparecem as histórias da retórica grega e latina de D. L. Clark, G. Kennedy, J. Martin e A. Leeman. Dando sequência ao labor de Charles S. Baldwin (Medieval Rhetoric and Poetic to 1400 Interperted from Representative Works, 1928) e E. R. Curtius (Europaische Literatur und lateinisches Mittelalter, 1948), a retórica medieval é estudada, entre outros, por H. Caplan, J. J. Murphy e J. Longère. Finalmente, a história da retórica renascentista sofre grande impulso com as obras e ediçôes de E. Garin, C. Vasoli, B. Weinberg e P.-O. Kristeller.

A partir de 1970, o crescente interesse pela retórica, e em particular pela retórica do período do Renascimento, beneficia também do geral desenvolvimento dos estudos sobre o Humanismo e da afirmação do Latim Renascentista como nova disciplina: é criada a International Association for Neo-Latin Studies, com os seus congressos bienais, relança-se a Humanistica Lovaniensia, é fundada a Société Française des Seizièmistes.

Assim, na década de 70 assiste-se na Europa a um verdadeiro 'renascimento da retórica'. Mas o interesse desloca-se do período do barroco para as retóricas dos sécs. XV e XVI. Religando retórica e política, surgem teses extremistas como as que identificam Renascimento e retórica (Burger) ou proclamam a 'ubiquidade da retórica' (Dockhorn, vd. Schanze 
1983: 105-125). Estudiosos como H. Gray, J. Seigel e N. Struever sustentam que a retórica constitui a chave de compreensão do humanismo e da cultura do Renascimento em geral. Posições mais razoáveis adopta P. O. Kristeller, embora se sinta na necessidade de clarificar a sua perspectiva:

«I do believe that Renaissance rhetoric is much more important, in need of much more study and attention, than most scholars of the past few generations were willing to admit. However, I never meant to say and I still do not believe that Renaissance humanism, let alone Renaissance thought and learning in general, is reducible to rhetoric alone» (Kristeller 1983: 1-19).

De facto, nos últimos trinta anos, propagase uma verdadeira pandemia retórica. É estudada a retórica de todas as épocas e lugares, é relacionada com as mais variadas disciplinas, é invocada a propósito de tudo e de nada: de palavra depreciada torna-se santo e senha de oportuno aggiornamento (Kennedy 1998). Multiplicam-se os colóquios e congressos, pululam os centros de investigação, reproduzem-se as sociedades científicas. Como exemplo, registem-se a International Society for the History of Rhetoric e The International Medieval Sermon Studies Society (que se desdobram em associaçóes nacionais), o European Center for the Study of Argumentation, dirigido por Michel Meyer, para não falar dos Departamentos de Retórica e Comunicação existentes em inúmeras universidades americanas. Para lá do efémero ficam as publicaçóes periódicas e 
colecçóes, como a Library of Rhetorics (Kluwer Academic Publishers), a Ars Rhetorica (Hitzeroth, Marburgo) ou, entre nós, a Argumentos (Ediçóes Asa). Além das revistas de estudos filológicos, linguísticos e literários que acolhem frequentemente trabalhos nesta área, são já legião os periódicos da especialidade, como o Quartely Journal of Speech, Speech Monographs (depois de 1968 Speech Abstracts e a publicação anual A Bibliography of Rhetoric and Public Adress), Argumentation, Rhetorica, Medieval Sermon Studies, Rhetorik, Rhetorical Society Quartely, Philosophy and Rhetoric, Logo, para não falar das publicaçóes digitais em edição on-line.

No longo processo, que se poderia designar de 'renascimento' da arte oratória, avulta, pois, como elemento decisivo, o interesse pela história da retórica e, em particular, a atenção que têm suscitado tratados, manuais e compêndios dos sécs. XV e XVI ${ }^{9}$. Ora, como se verá em trabalhos reunidos no presente volume, no período do Renascimento também em Portugal esta arte se tornou não só disciplina essencial à formação do humanista, como ainda doctrina que acabará por impregnar os demais saberes.

9 Testemunham o resultado de tal labor alguns Companions editados pela Cambridge UP, pela Brill ou pela Blackwell, e, na literatura mais especializada, obras como a Histoire de la rhétorique dans l'Europe moderne 1450-1950, ed. por M. Fumaroli (Paris, Presses Universitaires de France, 1999), a segunda edição do utilíssimo rol coligido por Lawrence Green e James Murphy, Renaissance Rhetoric. Short-Title Catalogue 1460-1700 (Adershot, Ashgate, 2006), ou a ainda mais recente $A$ History of Renaissance Rhetoric (1380-1620) de Peter Mack (Oxford, OUP, 2011). 
A retórica medieval revelara já múltiplas possibilidades de aplicação; a evidência da sua utilidade assegura a transmissão de alguns monumentos da herança greco-latina, mas concorre também para o aparecimento de novas disciplinas. No Portugal medievo, os preceitos, embora disponíveis em textos de Santo Agostinho e S. Gregório Magno, difundemse sobretudo através da enciclopédia de Santo Isidoro. Entrando o séc. XV, a pouco e pouco começam a emergir os clássicos, mais Cícero que Aristóteles, mais o Estagirita que Quintiliano; vencidos os estreitos limites da vulgata tardia, transmitida pelo livro II das Etymologiae, deixa a arte retórica de estar circunscrita à esfera eclesiástica. $\mathrm{O}$ interesse por Cícero e pela arte do discurso, favorecido pelas traduçóes patrocinadas pelos príncipes de Avis, eleva o saber retórico a fonte de distinçáo social. Mas, lembrava Cícero, no tratado que se tornou guia espiritual de humanistas, «tal como um campo, por fértil que seja, não pode dar fruto se não for cultivado, assim o espírito se não for ensinado» (Tuscul. 2. 13). Ora, lançando mão da metáfora agrícola presente no termo latino, poder-se-ia dizer que ao longo de Quatrocentos se foi preparando o terreno para receber o determinativo ciceroniano, a cultura animi, mudança que reclama acção humana, instrumentos adequados e vontade perseverante.

Com efeito, a vinda de mestres italianos, o envio de estudantes para Itália, a protecção da actividade editorial, a criação na corte de um ambiente favorável ao humanismo são méritos do reinado de D. João II. 
A obra de Cataldo comprova, como tem mostrado Américo da Costa Ramalho, esse primeiro esforço de integração da cultura nacional na respublica litteraria; é, pois, no último quartel do séc. XV que se alarga o nosso horizonte cultural, mercê da vulgarização do livro e da escrita, do intercâmbio com a pátria do humanismo, da renovação da pedagogia. Não tardam os frutos deste primeiro humanismo cortesão ou palaciano. No dobrar do século, surgem inequívocos sinais de mudança na prática escolar; os textos pedagógicos reflectem bem o conflito entre os apologistas dos novos métodos e os gramáticos de velha escola. Embora não isento de polémica, o processo não pára; atestam-no a gramaticografia, a lexicografia, a difusão da tratadística retórica e, restabelecida a comunicação entre a ars recte loquendi e a ars bene dicendi, rapidamente o ensino gramatical se orienta para a busca da eloquentia, faculdade indispensável ao discurso político e religioso. As oraçóes universitárias das primeiras décadas de Quinhentos documentam essa reconstrução da unidade dos saberes sob a égide da gramática, origo et fundamentum omnium liberalium artium, desenvolvimento que só a difusão de novos manuais tornou possível, ao transformar um saber meramente linguístico em disciplina de estudos literários. A influência de Lorenzo Valla e a circulação da Institutio Oratoria de Quintiliano contribuíram por certo para dar ao critério da elegância tal primazia na elaboração gramatical; por isso o usus, a imitação dos autores, se constitui agora indicador seguro do grau de aceitação da mensagem humanista. Ora, se à colonização 
retórica da instrução gramatical não é alheia a vontade de imitar os antigos, não será decerto ilegítimo presumir uma correlação entre o avanço dos estudos retóricos e o progresso do humanismo. Que as coisas assim se passaram comprovam-no tanto a eloquência sacra como a oratória profana; embora em graus diferentes, uma e outra tendem a preferir o discurso epidíctico, depreciando o docere em favor do mouere. Assim, apesar da dificuldade em fixar-se nos curricula escolares, após cinquenta anos de propagação do humanismo, para todos é claro o valor formativo e informativo da arte retórica.

Finalmente, com as reformas empreendidas por D. João III e a instituição de novos pólos de difusão do humanismo, náo só conquista a retórica merecida autonomia nos planos curriculares, como acaba também por estender a sua influência ao campo da dialéctica. $\mathrm{O}$ recenseamento dos materiais didáctico-pedagógicos disponíveis revela um aumento considerável dos meios de difusão da teoria oratória; no segundo quartel de Quinhentos, a circulação da retórica humanista foi sem dúvida extensa e profunda. Verificou-se, no entanto, por essas décadas de 1530-1540, uma mudança iniludível e de enormes consequências: sobretudo em razão da política cultural de D. João III - que não pode deixar de se associar a interesses comerciais e de estratégia diplomática - o humanismo norte-europeu torna-se o interlocutor principal do humanismo português. A vinda de mestres da área renano-flamenga, a formação parisina-lovaniense dos bolseiros régios, o acolhimento 
da obra de Erasmo são factores que não podem ser ignorados para se compreender a reorientação que sofrem então os estudos retóricos. A larga repercussão das obras de Trebizonda, Agrícola, Erasmo e Melanchthon, o acolhimento das suas doutrinas nos manuais de João Vaseu e Joachim Ringelberg modificam equilíbrios na economia do sistema retórico, alteram a relação entre as artes do discurso, interferem no modo de entender os retores clássicos. De facto, no que tange à recepçáo da retórica antiga, o humanismo em Portugal não deixa de acompanhar o que sucedia na Europa. Que a Retórica aristotélica não era ignorada mostram-no os comentários de António Pinheiro, algumas oraçóes académicas, ou o ensino de André de Resende; o mesmo se poderá dizer em relação à Institutio Oratoria de Quintiliano, considerando aqueles textos ou o compêndio de Nebrija. A influência destas obras, no entanto, não pode de forma alguma comparar-se à fortuna que conheceu a retórica ciceroniana, seja pelo conhecimento directo da tratadística do autor latino, seja pelo uso escolar das suas orationes e, tâo ou mais importante, pela tradução em vulgar de alguns dos seus diálogos mais apreciados. É verdade que o influxo do Estagirita nas escolas portuguesas ganhou novo fôlego com a abertura do Colégio das Artes, mas esse aristotelismo humanista nada acrescenta à concepção ecléctica que já distinguia a retórica do Norte. Decisivo, isso sim, continuava a ser o debate em torno da Tulliana imitatio; o que muda com a entrega do Colégio das Artes à Companhia de Jesus não será tanto a atenção a Aristóteles, mas a atitude perante 
o ciceronianismo. Não foram apenas razóes de ordem religiosa que levaram, por meados de Quinhentos, o humanismo português a virar-se de novo para Itália, acompanhando, aliás, um movimento mais geral que ultrapassa fronteiras confessionais. A partir dessa altura, limitado o contacto com as escolas da área norte-europeia, o humanismo devoto e a influência da Companhia de Jesus estabelecem entre nós o ciceronianismo moderado. Regressa uma concepção retórica centrada na aquisição da eloquentia que privilegia a sua utilidade e eficácia; como para os primeiros humanistas, a arte oratória passa a ser entendida antes de mais enquanto uis e facultas que uma contínua exercitatio pode aperfeiçoar. Como não podia ser ignorada a lição erasmiana, nem a redescoberta das doutrinas de Dionísio de Halicarnasso, Demétrio de Faléron ou do Pseudo-Longino, é, agora, sobretudo no ensino dos mestres jesuítas, um outro Cícero que é proposto à imitação, o Cícero imitador de Demóstenes que combina suauitas e uis oratoria, copia e emphasis, tudo regulando pelo critério do apte dicere. Assim se reanima, pois, mais uma vez o debate em torno da Tulliana imitatio; superada a controvérsia da imitação múltipla ou exclusivista, retornam com nova pertinência questóes que já tinham ocupado os primeiros polemistas do ciceronianismo: legitimidade do recurso aos spolia Aegypti, definição do optimus stilus, fixação de um modo de imitar.

Se a história da retórica nos oferece um excelente ponto de observaçáo do horizonte cultural de qualquer época, dada a natureza do movimento humanista, 
mais esclarecedora ainda se mostra no que respeita ao período do Renascimento. A busca da eloquência marca todo o esforço de renovação pedagógica empreendido pelos humanistas. Por isso, a questão da imitatio atravessa todo o século. Por essa razáo talvez se possa afirmar também que em nenhuma outra época foi tão estreita a dependência e contiguidade entre o ensino, a produção literária e a vida intelectual. Nas discussóes retóricas, poder-se-á reconhecer ao longo de todo o período uma linha de fractura entre duas concepçóes: por um lado, o entendimento aristotélico-ciceroniano da arte oratória como facultas que permite encontrar os meios adequados à persuasão; por outro, a perspectiva beletrística, fundada sobretudo em Quintiliano, que, vendo a retórica como uirtus e ars bene dicendi, favorece a reduçáo da arte ao estudo dos recursos elocutivos. Por isso os debates retóricos não se limitaram à esfera pedagógica ou literária: daquela oposição decorriam outras escolhas ricas de consequências, o problema da moralidade ou neutralidade moral da retórica, da compatibilidade entre a fé cristã e a cultura antiga, da autonomia do saber, do vínculo que une ou não a retórica às demais artes e ciências. Cícero, naturalmente, tinha que estar no centro de todas as discussóes e com ele a retórica, essa disciplina que vincula todas as artes, quae ad humanitatem pertinent. A influência italiana que marcou o primeiro meio-século de humanismo em Portugal poderia ter gerado algo mais do que uma certa abertura ao ciceronianismo exclusivista, não fora o forte condicionamento representado pelos discípulos 
de Poliziano. Numa segunda fase, nas décadas de 1530-1540, a preponderância de mestres formados em Paris e Lovaina, bem assim a recepção das doutrinas erasmianas, carregaram os contornos de outro tipo ciceroniano, o Cícero histórico redimido das peias de paradigma universal. É a uma nova versão desse Cícero, modelo de imitador, de fidelidade ao apte dicere, que regressa também o nosso ciceronianismo da segunda metade de Quinhentos; o interesse por Horácio e Aristóteles só contribuirá para lhe avivar os tons, dando-lhe suporte teórico e espessura histórica. Em contraste com as propostas parcelares ou restritivas da geração anterior, assim se apresenta no ensino dos jesuítas, ou na eloquentia de Tomé Correia, uma retórica integral que, fiel à concepção aristotélico-ciceroniana, reforça a ligação da arte oratória às demais disciplinas dos studia humanitatis, valorizando a elocutio e o ornato, mas também a inuentio e a tópica, quer dizer, a argumentatio, de modo a juntar à copia e à concinnitas a uis e a uehementia. Se a própria evolução do nosso humanismo, que se orientou primeiro para Itália, depois para o eixo Paris-Lovaina, e por fim para Roma, impediu a formação de uma corrente ciceronianista radical, não é menos verdade que em Portugal, ao longo de todo o período do Renascimento Cícero foi sempre o mestre mais seguido. 


\section{BibLIOGRAFia}

Branco, Camilo Castelo (1903, 2a ed.), O vinho do Porto: processo de uma bestialidade inglesa - Exposição a Tomás Ribeiro, Porto, Chardron, ${ }^{2} 1903$.

Fumaroli M., (1986), «Rhétorique d'école et rhétorique adulte: remarques sur la réception européenne du traité «Du Sublime» au XVIe et au XVIIe siècle», Révue d'Histoire Litteraire de la France $86: 33-51$.

Calboli, Gualtiero (1983), «L'Oratore senza microfono", Ars Rhetorica Antica e Nuova, Genova, Istituto di Filologia Classica e Medievale, $1983: 23-56$.

Verdelho, Telmo (1986), «Da isegoria: breve reflexão sobre o espaço verbal e o direito à palavra», Revista da Universidade de Aveiro. Letras 3 : 139-156.

Lempereur, A. (1990), L’homme et la rhétorique, Paris, Klincksieck.

Ijsseling, S. (1976), Rhetoric and Philosphy in Conflict: An Historical Survey, The Hague, Nijhoff.

Cohen, D. (1994), "Classical rhetoric and modern theories of discourse», in Worthington, I. (ed.) Persuasion, Greek Rhetoric in Action, London, Routledge: 69-82.

Manassero, M. (1994), «La nueva retórica de Chaim Perelman y la tradición aristotélica» in 
Ruiz Castellanos, A. (ed.), Primer encuentro interdisciplinar sobre retórica, texto y comunicación, t. I-II, Cádiz, Publicaciones de la Universidad de Cádiz: 288-293.

VAsoli, C. (1975), «La Nouvelle rhétorique di Perelman», in. Baehr, Rudolf (ed.), Attualità della rettorica. Atti del convegno italo-tedesco (Bressanone, 1973), Padova, Liviana Editrice:15-36.

Gadamer, H. G. (1994, 2a ed.), Verdad y método II, Salamanca, Ediciones Sígueme.

Fumaroli, M. (1987-88), «Rhétorique et société en Europe (XVIe-XVIIe siècles)». In «La République des Lettres» (I), Annuaire du Collège de France 88 : 417-434.

Lanson, Gustave (1902), L'Université et la societé moderne. A. Colin.

Fumaroli, M. (1979), «Protée et Prométhée: réflexions sur l'histoire de la Rhétorique» in Colloque sur la Rhétorique. Calliope I, Paris, Les Belles Lettres: 363-373.

Genette, G. (1969), «Enseignement et rhétorique au XXe siècle», Figures II, Paris, Seuil, 1969: 23-42.

Classen, C. J. (1988), "Ars Rhetorica: L' essence, possibilities, Gefahren», Rhetorica 6.1: 7-19.

Schanze, H. (1983,) «Problems and Trends in the History of German Rhetoric to 1500», in 
Murphy, J. (ed.), Renaissance Eloquence, Berkeley, University of California Press: 105-125.

Kristeller, P. O. (1983), "Rhetoric in Medieval and Renaissance Culture», in Murphy, J. (ed.), Renaissance Eloquence, Berkeley, University of California Press: 1-19.

Kennedy, G. (1998), Comparative Rhetoric, Oxford, Oxford University Press.

Barthes, R. (1870), «L'ancienne rhétorique. Aidemémoire», Communications 16 : 172-229.

Fumaroli, M. ed. (1999), Histoire de la rhétorique dans l'Europe moderne 1450-1950, Paris, Presses Universitaires de France.

Green, L. - Murphy, J. (2006), Renaissance Rhetoric. Short-Title Catalogue 1460-1700, Adershot, Ashgate.

Mack, P. (2011), A History of Renaissance Rhetoric (1380-1620), Oxford, OUP. 


\title{
DisCURSOS DISTINTOS PARA CONCEPÇÓES DIFERENTES DA FÉ CRISTÁ
}

\author{
António Ribeiro Rebelo
}


Perante a mesma situação, a Fé do cristão medieval pode conduzir a leituras divergentes dos factos, suscitadas por uma vivência multímoda dos princípios evangélicos que tem implicaçóes significativas no seu modo de agir e de pensar. Esta multiplicidade interpretativa, que os textos sagrados e as obras das grandes figuras da História da Igreja permitem, reflecte-se igualmente nos textos literários, designadamente na historiografia e na hagiografia. Os discursos são os elementos mais exemplificativos, porque caracterizam, de forma directa, a maneira de pensar e a forma de agir das personagens.

A este propósito, propomo-nos analisar detidamente os discursos de D. Fernando e D. Henrique proferidos por ocasiáo da conquista de Tânger e registados na biografia latina de D. Fernando - o Martyrium et Gesta Infantis Domini Fernandi... (doravante Martyrium et Gesta...). São discursos literários extensos, que não se encontram atestados nem em Fr. João Álvares, nem em Rui de Pina. No âmbito da obra, constituem o núcleo historiográfico:

o $4^{\circ}$ discurso (de D. Henrique): lin. 330-353;

o $5^{\circ}$ discurso (de D. Fernando): lin. 416-446;

o $6^{\circ}$ discurso (de D. Henrique): lin. 446-452;

o $8^{\circ}$ discurso (de D. Henrique): lin. 476-494;

e o $9^{\circ}$ discurso (de D. Fernando): lin. 496-514. 
Estes discursos incidem essencialmente na discussão da posição confrangedora em que os soldados portugueses se encontram depois dos reveses na tentativa da conquista de Tânger, no Verâo e Outono de 1437. Sobretudo as alocuçóes que precedem a rendição, durante as quais são pesadas as vantagens e desvantagens, bem como os termos do armistício, são elementos retóricos de uma forte densidade dramática que exploram a trágica situação em que os Portugueses se haviam colocado. Mais que quaisquer outros passos, estes discursos permitem moldar, à maneira de Tito Lívio $^{1}$, um retrato dinâmico dos dois protagonistas do Martyrium et Gesta..., D. Henrique e D. Fernando, evidenciando, de forma bem clara, forças de tensão opostas.

Estas peças de notável oratória exprimem ideais aparentemente antagónicos porque enfatizam maneiras diferentes de sentir e viver o cristianismo, fruto de interpretaçóes diversas dos sinais divinos ou dos sinais dos tempos: se uma das atitudes radica na humildade e, por conseguinte, no sentimento de o ser humano se considerar indigno de uma intervenção divina, aliado à responsabilidade cristâ, perante Deus, pela salvação eterna dos homens que a Pátria lhes confiou, a outra

${ }^{1}$ A finalidade estilística do discurso em Tito Lívio prende-se não só com o retrato psicológico das personagens, mas também com a exposição de uma determinada situação na sua globalidade. Além disso, os discursos serviam para imprimir maior vivacidade ao texto, através do equilíbrio estabelecido com as partes essencialmente descritivas e narrativas. Cf. Bayet, Jean (1965), Littérature latine, Paris, p. 244. 
baseia-se no secular espírito de cruzada, numa fé firme e determinada no auxílio divino - uma fé que, como diz o Evangelho, é capaz de fazer mover montanhas -, aliada a uma esperança indefectível na conquista da salvação eterna em caso de morte.

$\mathrm{O}$ facto de não se encontrarem registados nos cronistas da época leva a crer que os discursos do Martyrium et Gesta... são fictícios, à maneira dos historiógrafos clássicos ${ }^{2}$, ainda que possamos afiançar que o biógrafo fernandino recorre a outras fontes que os outros cronistas não registam ${ }^{3}$. A bem dizer, a influência clássica evidenciada pela intertextualidade literária, a um nível macro-estrutural, é confirmada por uma intertextualidade linguística, com particular incidência nas características semânticas, assimiladas pelo idiolecto do autor, e nas sintácticas. Efectivamente, é ao longo deste núcleo central, de natureza essencialmente historiográfica que se concentram as citaçôes de autores clássicos ${ }^{4}$. Este processo foi também muito utilizado por

${ }^{2}$ Vd. Bayet, Jean (1965), Littérature latine, Paris, p. 168: A l'exemple des Grecs, les historiens latins s'étaient mis à composer des discours, même fictifs, en tout cas outrepassant leur documentation réelle, qu'ils prêtaient aux personnages principaux en des circonstances notables, et qui leur permettaient d'exposer de façon vivante soit l'ensemble d'une situation, soit les fondements d'une entreprise.

3 Efectivamente, o biógrafo anónimo não circunscreveu as suas fontes à matéria desenvolvida no Trautado de Fr. Joáo Álvares. Terá usado outro tipo de informaçôes, escritas ou orais, às quais o redactor da Crónica de El-Rei D. Duarte terá recorrido - independentemente de Rui de Pina se ter ou náo servido de materiais de Zurara ou de Fernáo Lopes.

${ }^{4} \mathrm{O}$ facto de o autor aliar narraçôes puramente historiográficas 
Rui de Pina, sobretudo nas crónicas que lhe são mais genuínas: a de D. Afonso V e a de D. João $\mathrm{II}^{5}$.

$\mathrm{Na}$ Antiguidade Latina, era o discurso que caracterizava o melhor estilo de Salústio ${ }^{6}$. Era também o discurso um processo emblemático da historiografia liviana: na totalidade da obra que chegou até nós, contam-se quatro centenas de discursos!

Conjugam-se, pois, nos discursos do Martyrium et Gesta..., os principais traços distintivos dos historiadores latinos da Antiguidade. As próprias características linguísticas parecem ser o reflexo disso ${ }^{7}$. No Martyrium et Gesta... revelam uma arguta análise psicológica à maneira de Tácito. O historiador latino privilegiava o sentido pragmático dos factos. Como esse pragmatismo é exercido pelos agentes ou protagonistas

a uma obra de cariz essencialmente hagiográfico poderia explicar-se mediante o intuito de conferir maior verosimilhança a um texto que se enquadrava indubitavelmente num género que, pelos excessos que, por vezes, eram cometidos, corria o risco de cair no descrédito ou na rotina de tópicos, de milagres, que acabavam por ser considerados lugares-comuns. Todavia, julgamos que as razóes que poderão ter influído na elaboraçáo de um discurso narrativo com um peso historiográfico tão relevante numa obra de cariz predominantemente hagiográfico serão sobretudo de ordem literária.

${ }^{5} \mathrm{Vd}$. e. g. a caracterização das referidas crónicas em Gomes, R. Costa (1993), "Rui de Pina" in Giulia Lanciani e Giuseppe Tavani (org. e coord.), Dicionário da Literatura Medieval Galega e Portuguesa, Lisboa,.

${ }^{6}$ Cf. Bayet, Jean (1965), Littérature latine, Paris, p. 173: "Aussi a-t-il trouvé dans la forme traditionnelle du discours son véritable mode d'expression [...]".

${ }^{7}$ Cf. e.g. Paratore, Ettore (1987) História da Literatura Latina, trad. de Manuel Losa, SJ, Lisboa, pp. 736 sq, a propósito do estilo de Tácito. 
da História, a sua prioridade consiste em perscrutar a alma, os pensamentos e os sentimentos dessas pessoas, expondo ao público as secretas forças impulsoras das suas acçóes. A primazia do discurso é concedida ao retrato da alma, que explica todos os procedimentos do indivíduo. É que o rumo da História é determinado pelas características psicológicas dos seus agentes e, por sua vez, os eventos brotam, com toda a naturalidade, do carácter das personagens históricas. Também o autor do Martyrium et Gesta... soube plasmar nos respectivos discursos as personalidades de D. Henrique e do Infante D. Fernando.

A intrepidez que D. Henrique evidencia nas diversas intervençóes ao longo do Martyrium et Gesta... (designadamente as lin. 331-333, 335, 337-338, 450-452 e 482-485), fundamentada, por sua vez, numa confiança absoluta na Divina Providência, enquadra-se no espírito do ideal de cavalaria, na tradição do miles Christi, que alia o fervor religioso ao ardor guerreiro ${ }^{8}$. Lembremos que, já na guerra de Ceuta, o jovem Infante manifestara estas características. No De Bello Septensi de Mateus de Pisano, D. João I ordena que ninguém desembarque antes de D. Henrique o ter feito9. É o jovem Infante, cioso de feitos gloriosos, a fim de poder ser armado cavaleiro, que deseja ser o primeiro a pisar as areias de Ceuta ${ }^{10}$.

${ }^{8}$ Cf. e.g. Livro dos Conselhos de El-Rei D. Duarte (fol. $131^{\mathrm{v}}$ e $132^{\mathrm{r}}$ ).

${ }^{9} \mathrm{Vd}$. BDVV, ms. $n^{\circ} 1$, fol. 35": "His dictis, imperauit uti omnes ad desiliendum se pararent, nibilominus nemo prius desiliret quam Henricum desilijsse uideret".

${ }^{10}$ Cf. Gomes Eanes de Zurara, Crónica da tomada de Ceuta, 
Não admira, pois, que deste miles Christi, a um tempo animado por um ardente proselitismo religioso e vibrante de um incontível entusiasmo na perspectiva de mais um feito bélico, sobressaia uma confiança absoluta e incondicional na Divina Providência. Assim se explica a citação bíblica dos dois livros dos Macabeus na lin. 333 do Martyrium et Gesta...: "Não é na quantidade de homens, mas na misericórdia divina que devemos esperar do Céu a vitória “ (Non in multitudine, sed in misericordia Dei de caelo speremus uictoriam), uma expressão composta a partir de dois passos bíblicos diferentes: 1Mcc 3.19 ("non in multitudine exercitus est uictoria belli, sed de caelo fortitudo est") e $2 \mathrm{Mcc}$ 15.8 ("adiutoria sibi facta de caelo et nunc sperarent ab Omnipotente adfuturam sibi uictoriam").

A resistência de Matatias e de seus cinco filhos, os Macabeus, entre os quais avultava Judas, passou para a tradição judaico-cristá como uma das principais referências de heroicidade veterotestamentária. $\mathrm{Na}$ literatura latina medieval, a citação explícita de $1 \mathrm{Mcc}$ $3.18-19^{11}$ ocorre, pela primeira vez, no famoso elogio

cap. 24. O mesmo autor, no cap. 71 desta crónica, confirma que as hostes do Navegador foram as primeiras a entrar na cidade.

${ }^{11}$ Contextualizemos este passo: Mas ao verem aquele exército que marchava contra eles, os companheiros disseram a Judas: "Como poderemos nós, tấo poucos, combater contra tão grande multidão, tanto mais que nos sentimos fracos por estarmos hoje ainda em jejum?”. Mas Judas respondeu: "É fácil que muitos venham a cair às mãos de poucos; para o Deus do céu não há diferença entre salvar com muitos ou com poucos, porque o triunfo de uma batalha não depende do número de soldados, mas da força que vem do céu" (Et ait Iudas: "Facile est concludi multos in manibus paucorum; et non est differentia in conspectu caeli liberare in multis 
dos Templários por S. Bernardo, o Liber Ad Milites Templi - De Laude Nouae Militiae, onde o abade de Claraval delineia a missáo e o espírito da nova cavalaria. A partir daí, é retomada na literatura de cruzadas e nas crónicas da reconquista:

Irrompem sobre os adversários, como se os inimigos fossem gado, e, ainda que sejam muito poucos, jamais temem a bárbara crueldade ou a numerosa multidão. Estão igualmente ensinados a não confiar nas suas próprias forças, mas a esperar a vitória do poder do Deus dos Exércitos, e nessa ordem de ideias acreditam ser extremamente fácil, segundo a expressão do Macabeu,

"que muitos venham a cair às mãos de poucos e que para o Deus do céu não há diferença entre salvar com muitos ou com poucos, porque o triunfo de uma batalha não depende do número de soldados, mas da força que vem do céu."

Isto eles têm experimentado também com muita frequência, a ponto de muitas vezes um único ter posto em fuga um milhar de homens e dois terem afugentado dez $m i l^{12}$.

aut in paucis, quoniam non in multitudine exercitus victoria belli, sed de caelo fortitudo est.).

${ }_{12}$ S. Bernardo, Liber Ad Milites Templi - De Laude Nouae Militiae, 4.8 , in J.-P. Migne, PL 182, pp. 921-940 ou Bernhard von Clairvaux (1990), Sämtliche Werke, lateinisch und deutsch (ed. Gerhard B. Winkler), Innsbruck: Irruunt in aduersarios, hostes uelut oues reputant, nequaquam, etsi paucissimi, uel saenam barbariem, uel numerosam multitudinem formidantes. Nouerunt siquidem non de suis praesumere uiribus, sed de uirtute Domini 
Antes de o biógrafo fernandino o adaptar ao seu texto, já o tópico do Livro dos Macabeus fora utilizado por D. João I antes da Batalha de Aljubarrota ${ }^{13}$ e a ele recorrera também D. Duarte, no seu Livro dos Conselhos: "[...] lembrandouos quantos catholicos prinçipes e outros da ley uelha, com muy pouca gente, uençerom grande multidom de jnfieis[...]".

O Mestre da Ordem de Cristo, sucessora da Ordem do Templo, tomava a sério o papel tradicional de miles Christi e a função de cruzada permanente contra os infiéis. Não admira, pois, que D. Henrique procurasse seguir à letra tudo quanto S. Bernardo prescrevia no seu Liber Ad Milites Templi, que passou a ser um verdadeiro decálogo para os cavaleiros templários. Daí que o Navegador estivesse pronto a dar a sua vida por Cristo. Efectivamente, do pormenor da referência à bula de cruzada (lin. 227) infere-se a remissão plenária dos pecados dos combatentes lusitanos, por si só razão suficiente para se advogar um futuro beatífico para todos quantos viessem a sofrer a morte na sequência de um

Sabaoth sperare uictoriam, cui nimirum facile esse confidunt, iuxta sententiam Macchabaei, concludi multos in manus paucorum, et non esse differentiam in conspectu Dei caeli liberare in multis, et in paucis, quia non in multitudine exercitus est uictoria belli, sed de caelo fortitudo est. Quod et frequentissime experti sunt, ita ut plerumque quasi persecutus sit unus mille, et duo fugarint decem millia.

${ }_{13}$ Fernáo Lopes faz alusão ao episódio do Macabeu nos capítulos 30, 41 e 48 da Primeira Parte da Crónica de D. João I (cf. Fernão Lopes (1977), Cronica del Rei Dom Joham I de boa memória $e$ dos Reis de Portugal o decimo, Parte Primeira escrita por Fernão Lopes. Reprodução fac-similada da edição do Arquivo Histórico Português (1915) preparada por Anselmo Braamcamp Freire. Prefácio por Luís F. Lindley Cintra, Lisboa). 
eventual desenlace fatal dos acontecimentos. E, no seu segundo discurso (lin. 446-452), D. Henrique admite mesmo a morte como fuga para a glória:

"É próprio de um espírito inteligente e ilustre aceitar ou preferir morrer uma só vez pela Fé a ter uma vida longa e morrer muitas vezes com o nome difamado. [...] está estabelecido que todo o homem morre uma só vez" (Ingenui et praeclari animi est liberius et melius pro fide semel mori, quam diu uiuere, saepius turpi nomine moriendo. [...] statutum enim est omni homini semel mori).

Muito particularmente nas lin. 447-449, integradas no discurso de D. Henrique, é a honra que está em causa. O Infante de Sagres invoca uma das maiores virtudes dos grandes heróis épicos e um dos grandes ideais da cavalaria: a salvaguarda da honra a todo o custo. O legado clássico encontra-se pejado de verdadeiros paradigmas de heroísmos deste jaez.

A atitude do Mestre da Ordem de Cristo era entendida outrora, à luz da mentalidade medieval e do ideal de cavalaria, como uma das maiores virtudes ${ }^{14}$. Os

14 Efectivamente, no De Bello Septensi, Mateus de Pisano comprova que este sentimento não era inédito. Quando a frota chegou a Ceuta, foi desmembrada por uma violentíssima tempestade. Reunidos os cerca de 250 vasos que constituíam a armada, D. João I sonda as intenções das suas tropas, inquirindo se sempre mantêm a disposição de atacar Ceuta ou se preferem avançar para outras bandas. São várias as opinióes. Os jovens Infantes, ansiosos por merecerem o grau de cavaleiro, preferem, já então, a honra da morte à ignomínia da escusa em se exporem aos perigos (Ideo prestare omnia ferre pericula quam ignominia notari, cui honesta mors est preferenda). Vd. BDVV, ms. $n^{\circ} 1$, fol. $32^{v}$. Cf. 
sentimentos que D. Henrique manifesta no Martyrium et Gesta... já ele os herdara de seu pai, como se pode constatar pela forma como as expressóes de D. Joáo I, vertidas por Fernão Lopes e Zurara, são aplicadas pelos cronistas latinos a D. Henrique. Eram mentalidades típicas de uma época influenciada pelo espírito de cavalaria, alimentada pela leitura das gloriosas proezas de Galaaz, o cavaleiro puro, e da demanda do Graal pelos míticos cavaleiros da Távola Redonda.

Porém, os ideais dos dois tipos de cavaleiro (secular e religioso) constituíam uma amálgama indissolúvel de sentimentos no espírito do Infante de Sagres. Um aspecto pressupunha o outro e esta combinação de sentimentos reflectia-se no modus agendi do Mestre da Ordem de Cristo.

É assim que o Infante D. Henrique explana aos seus homens as desvantagens que o armistício teria para Portugal e as consequências negativas da desonra pessoal com que cada um deles seria coberto para os anos vindouros. Onde os Portugueses desvalorizavam as implicaçôes morais e legais dos termos da rendição, dizendo que não tinham poderes para prometerem a troca de Ceuta (lin. 471), D. Henrique contrapunha que, apesar disso, se devia manter a palavra a todo o custo.

O Navegador colocava, por isso, a morte honrosa acima da vergonha da derrota, como se pode depreender das lin. 480 sqq: "Eu, pela minha parte, preferia dilatar

igualmente Gomes Eanes de Zurara, Crónica da tomada de Ceuta, cap. 61. 
o firm da guerra a cair nas mãos dos infiéis" (Ego ipse liberius optarem belli finem immorari quam in Infidelium manus incidere $)^{15}$. Em primeiro lugar, revela a nobreza do seu carácter e o sentido da honra e do dever. Em segundo lugar, confirma o que os nobres haviam alegado (nas lin. 248-250) para atribuírem o comando da expedição ao Infante de Sagres:

"o qual - nós bem o sabemos - teme mais a infâmia do que a morte e tem em maior conta a honra do que o seu bem-estar ou outras comodidades" (quem nouimus plus turpitudinem horrere quam mortem et plus ad honestatem quam ad salutem uel ad alia commoda expectare).

Já D. Fernando se revela mais realista e responsável nas intervençôes. A decisão de se entregar como refém em troca da libertação de seu amado irmão e dos seus homens, que viam nele um pai espiritual (lin. 26 sq) revela uma preocupação preponderantemente religiosa. O Infante Santo assume a atitude do pelicano e, qual alter Christus, oferece-se pela salvação espiritual daqueles seus filhos que correriam o risco de renegar a fé cristấ sob coacção, torturas e maus-tratos durante o duro cativeiro africano que os esperaria. Não o afligia apenas o perigo de ter que prestar contas a Deus pela

${ }^{15}$ Esta afirmação pode não parecer muito abonatória do carácter de D. Henrique, mas ela é passível de uma dupla interpretação e deve ser entendida na perspectiva do comentário sobre as lin. 449 sqq: "É, com efeito, amarga a fama que nos espera, se formos vencidos por estes câes" (Amara siquidem nobis sistit fama, si ab istis diuincimur canibus). 
perdição daqueles que lhe haviam sido confiados. $\mathrm{O}$ seu procedimento era coerente com a sua preocupação em resgatar os Cristãos cativos dos infiéis (Martyrium et Gesta... lin. 166-169). Jamais ele poderia consentir ser responsável por uma desgraça que ele próprio considerava táo atroz.

Há, portanto, uma diferença de perspectivas entre D. Fernando e D. Henrique. Enquanto D. Fernando se preocupa sobretudo com a salvação das almas, para D. Henrique é antes a honra que é posta em causa, a reputação, a opiniáo pública, o julgamento do povo e da Corte, perante o vexame de uma derrota desonrosa, quando regressar à Pátria de mãos vazias e com a promessa de restituir Ceuta, que seu pai havia conquistado ${ }^{16}$. Sendo ele o chefe da expedição é sobre a sua pessoa que recairia a responsabilidade da derrota. É por isso que entre a morte pela Fé e a desonra ele prefere a primeira, que lhe assegurava a eternidade e só aumentava os méritos do seu renome. É, pois, compreensível que ele tente convencer os outros companheiros a seguirem esta soluçáo. Mas, por outro lado, D. Henrique evoca, nesta ocasião, a efemeridade da vida humana ( lin. 451 sq): "está estabelecido que todo o homem morre uma só vez" (statutum enim est omni homini semel mori). Estas palavras, citadas de $\mathrm{Hbr} 9.27$ ("statutum enim est hominibus semel mori”), com as quais ele procura

16 D. Henrique assume aqui uma atitude consentânea não apenas com o espírito de cavalaria, mas também com o carácter do herói épico que só vê a sua glória eternizada se os seus feitos forem celebrados pelos poetas. 
animar as suas tropas e que são o culminar de todo um discurso em que o Navegador evidencia a sua coragem, abnegação e determinação em lutar até à morte, se necessário for, produzem, todavia, o efeito contrário entre as suas gentes. Como estes náo tinham sobre os ombros a responsabilidade militar, política e histórica de D. Henrique, a possível desonra também não os incomodava, por ficar diluída no anonimato dos seus modestos cargos.

Por sua vez, os capitães portugueses invocam um argumento ao qual o Infante D. Fernando náo ficaria insensível: o da responsabilidade dos graduados perante Deus, se, na sequência de uma má decisão, os seus subalternos viessem a cair nas máos dos inimigos e renegassem a sua fé ${ }^{17}$.

$\mathrm{Na}$ resposta a um dos discursos do comandante-chefe da missão, os soldados lusitanos davam antes ouvidos às razóes de D. Fernando e encontraram argumentos adicionais de natureza soteriológica, para inclinar o Príncipe Constante à solução do armistício (lin. 464-465): "Nosso Senhor, vencedor da morte, não veio, de facto, para salvar as pedras, mas antes para salvar os homens" (Dominus Noster, destructor mortis, non reuera uenit saluare lapides, immo uerius homines).

Como é evidente, o autor fez aqui uma adaptação consciente do propósito de Cristo, transmitido pelo

${ }^{17}$ Ao narrar os factos desta maneira, o autor acaba por ilibar também o Infante D. Henrique da responsabilidade na futura morte do irmáo, porque foi este que assim quis que se fizesse. Ao mesmo tempo, salvaguarda a honra do comandante, uma vez que D. Henrique pretendia lutar até à morte. 
Evangelho de S. Lucas: "non ueni uocare iustos, sed peccatores" (Lc 5.32). No texto de Lucas, a oposição está condicionada aos seres humanos: os justos e os pecadores. No contexto de Tânger, é um argumento de maior peso, porque opóe os seres humanos às pedras (i. e. Ceuta). $\mathrm{Na}$ espiritualidade cristâ, esta questão não chegava a pôr-se. Colocar seres inanimados no mesmo plano ou até acima dos seres animados e racionais, seria subverter por completo o projecto divino da Criação, uma vez que os elementos foram colocados ao serviço do Homem e não ao inverso. O argumento aqui exposto é, pois, inabalável e $\mathrm{D}$. Fernando não deixa de ser sensível a este aspecto.

De um modo geral, os discursos em si são literariamente bem elaborados e estão conformes à retórica e oratória da época. A belicosa intervenção do Infante D. Henrique (lin. 330-353), por exemplo, em que o Navegador, incansável e inconformado, tenta dar novo alento às suas tropas, apelando ao brio e à intrepidez dos soldados de Cristo, para que se entreguem inteiramente e de forma denodada à luta, não cumpre todos os itens da retórica clássica, ainda que seja este o trecho que concentra mais citaçóes de autores clássicos. $\mathrm{Na}$ verdade, a probatio é desenvolvida com recurso a inúmeras auctoritates clássicas (Séneca, por três vezes, e ainda Virgílio, Lucano e Cícero), para reforçar o impacto argumentativo. Todavia, a acumulação de tantos exemplos deste genus artificiale da probatio, deixa transparecer o desespero do Navegador na tentativa de convencer o seu auditório. 
O biógrafo latino recorre à autoridade de Séneca, para reforçar algumas das afirmaçóes do discurso de D. Henrique, emprestando-lhe o vigor expressivo que é característico das máximas e provérbios. Séneca e Cícero são os autores clássicos mais citados ao longo do Martyrium et Gesta... E não admira, pois eram muito populares na corte de Avis. D. Henrique inspirase muito em Séneca e em Virgílio para encorajar e animar os Portugueses, abatidos pela inferioridade numérica. Esgotados os artifícios retóricos, o jovem príncipe recorre a grandes autoridades literárias e lança mão de todos os argumentos, para incentivar as tropas desmoralizadas. Sobretudo o primeiro discurso henriquino é de profundo sabor clássico: além do filósofo cordovês, são citados Lucano e Cícero, por diversas vezes, para sublinhar a ética, a justiça e a equidade. D. Henrique volta a citar Cícero na lin. 490, recuperando a ética e a honra dos antigos, em sintonia com o código de cavalaria: "a palavra deve ser mantida mesmo para com o inimigo" (fides etiam hosti seruanda est).

O autor recorre ao cursus uelox para fazer visualizar quer a angústia ou aflição das circunstâncias, quer o entusiasmo, ou quando acompanha actos de fala, sobretudo se se tratar, designadamente no caso do Infante D. Fernando, de instigar os seus companheiros ao cumprimento da doutrina e à perseverança na fé ou de os encorajar no âmago da peleja ${ }^{18}$. O cursus tardus sobressai nas circunstâncias que exigem prudência,

${ }^{18}$ E. g. lin. 423-424. 
ponderaçáo ${ }^{19}$, ou quando a situação se pauta pela seriedade, pela gravidade ${ }^{20}$.

Já o primeiro discurso de D. Fernando (lin. 416-446) é dos mais perfeitos, de acordo com as regras da retórica. No exordium, evidencia-se a captatio beneuolentiae, a par do tópico attentum parare. D. Fernando expóe a causa na narratio, não sem deixar de tecer largas graças e louvores à protecção divina que até então havia acompanhado o exército português. Prepara, assim, a afirmação posterior "Nec reor [...] Deum nos temptare licitum esse", que, em virtude da anterior exaltação do auxílio divino, já não pode ser interpretada como descrença na Divina Providência ou falta de fé por parte de D. Fernando. Depois, faz o levantamento objectivo da situação crítica em que os Portugueses se encontram. Segue-se a argumentatio, onde o autor desenvolve a defesa da sua posição (probatio). Faz a refutatio do discurso irrealista, resultante de uma fé excessiva na intervenção divina, não por falta de fé, mas antes por se reputar humildemente indigno dessa manifestação. Julgar o contrário seria, isso sim, pôr Deus à prova. Esta frase "Nec reor Deum nos temptare licitum esse" (lin. 438) é mais um caso em que o texto mais antigo provém de Dt 6.16, mas que os Cristãos conhecem melhor através do passo do NT, Mt 4.7, onde Cristo remete de forma directa para o texto do AT: "non temptabis Dominum Deum tuum". Este passo foi enquadrado no discurso de D. Fernando, quando ele faz a apologia da rendição

\footnotetext{
${ }^{19}$ E. g. lin. 475.

${ }^{20}$ E. g. lin. 348.
} 
perante as dificuldades e a inferioridade numérica dos Portugueses, já sem esperanças de salvação.

Finalmente, conclui o discurso com uma breve peroratio, preconizando a entrega de Ceuta em favor da salvação das almas dos seus companheiros de armas.

Alguns dos argumentos desenvolvidos nesta alocução do Infante Santo são retomados no discurso dos militares. Nas lin. 431-446 do primeiro discurso, o autor recorre a uma argumentação justificativa, típica da oratória judicial. Nestes passos, o autor expóe argumentos religiosos, com base nos quais desenvolve uma forte apologética que justificaria a rendição dos Lusitanos aos olhos de qualquer personalidade eclesiástica, incluindo o Papa.

No discurso seguinte (lin. 476-494), D. Henrique manifesta a sua discordância relativamente ao teor das argumentaçóes até aí desenvolvidas, renova a sua argumentação com motivos que ele julga irrecusáveis e incita as tropas à luta com entusiásticas palavras de encorajamento. É no âmbito desta divergência de opinióes entre o grosso das tropas lusas e o seu comandante, o Infante D. Henrique, que sobressaem as argumentaçôes e contra-argumentaçôes de uma e outra parte, acompanhadas de citaçóes de textos jurídicos. As posiçôes antagónicas são reforçadas por advérbios, conjunçôes, locuçóes, antonímia, combinaçóes vocabulares antitéticas, figuras de estilo... ${ }^{21}$

O estilo argumentativo é evidenciado através de conjunçốes que introduzem razões de direito, as

${ }^{21}$ E. g. non reuera..., immo uerius...; non..., sed...; aut..., aut...;... 
quais, por sua vez, impóem razóes de facto e levam a uma conclusão: quia, quoniam, ergo. $\mathrm{O}$ único registo de ergo ocorre na lin. 462, em plena argumentação de cunho vincadamente forense, onde se pesam os prós e os contras da decisão a tomar em função da ameaça das circunstâncias vigentes:

Os inflamados discursos do Martyrium et Gesta... apelam constantemente à qualidade de cavaleiros dos combatentes portugueses, cavaleiros com a responsabilidade acrescida da fé cristá que subjaz à sua condição de milites Christi. Mas o temporal e o espiritual colidem, quando se torna necessário decidir o futuro das hostes portuguesas.

D. Henrique apela à honra e dignidade de cavaleiro (lin. 446-452) - Amara siquidem nobis sistit fama, si ab istis diuincimur canibus ${ }^{22}$ - e, quando aduz argumentos baseados na fé cristâ, fá-lo para consolidar a defesa da honra de cavaleiro (lin. 476-494).

D. Fernando, que, por um lado, sempre demonstrara uma grande preocupação com o bem-estar físico e espiritual daqueles que thes haviam sido confiados e, por outro, punha tanto empenho na libertação dos cristáos cativos, jamais poderia aceitar a responsabilidade de criar uma situação de cativeiro para tanta gente, ele que tanto dinheiro gastara a remir cativos. A única solução possível e congruente com a sua perspectiva doutrinária, seria assumir ele próprio as consequências e carregar aos ombros o sofrimento dos seus correligionários.

22 "É, com efeito, amarga a fama que nos espera, se formos vencidos por estes cães". 
Já sabíamos que o amor paroxístico pelo Divino, pelo Transcendente, próprio de uma alma devota e piedosa, despertava no jovem Mestre de Avis um desejo intenso de seguir o Salvador até ao suplício supremo A imitação de Cristo por D. Fernando, tão típica do franciscanismo e da deuotio moderna, assume nas lin. 496-514 o seu expoente máximo com a entrega voluntária de D. Fernando como refém em prol da salvaçáo dos seus companheiros de armas e sobretudo de seu irmão, D. Henrique. O episódio começa com uma prelecção de $\mathrm{D}$. Fernando, que mais não é senão uma fundamentação explicativa do seu propósito.

Perante uma situação desesperada, de derrota iminente, qual a atitude mais correcta do cristáo: renderse às evidências e poupar a vida de seres humanos ou acreditar na vitória divina?

Como D. Fernando argumentou, um dos pecados capitais consistia em pôr à prova o próprio Deus. D. Fernando deseja evitar esse perigo, pois a vitória só poderia ser alcançada mediante uma intervenção divina directa: um milagre. Todavia, ao insistir na continuação do combate, a despeito de todas as contrariedades, D. Henrique nunca pensou em tentar a Deus. Pelo contrário, a sua atitude acusava uma fé inabalável no poder do Altíssimo, uma fé de fazer mover montanhas. A sua confiança é de tal modo absoluta que náo vacila perante as adversidades da realidade. D. Henrique encarna o ideal do miles Christi, o monge cavaleiro, onde o fervor religioso se objectiva num esto guerreiro ${ }^{23}$.

${ }^{23}$ Vd. Saraiva, José Hermano (1948), "Uma carta do Infante 
Isto não significa que D. Fernando tivesse menos fé que D. Henrique. Seria porventura mais realista, porque se julgaria indigno do socorro divino, sobretudo sob a forma de milagre. Além disso, D. Fernando pensava nos seus homens, nas respectivas famílias e principalmente no perigo de muita gente poder vir a abjurar a fé cristã no cativeiro. Preferia, como aconteceu, oferecer-se a si próprio em livramento de seus companheiros, a ser responsabilizado perante Deus pela perdição de tantas almas.

Embora os dois pontos de vista apontassem para decisóes completamente opostas, eram inteiramente coerentes com a vivência cristã e a dimensão espiritual de cada um dos príncipes de Avis. Nos dois irmãos, que dirigem a expedição, encontram-se, assim, conjugados os dois tipos de cavalaria: o cavaleiro e o monge, o temporal e o espiritual. Os dois Infantes complementam-se um ao outro, encarnando, assim, uma simbiose dos dois estados de espírito do cavaleiro de Cristo.

D. Henrique e o problema das causas da expansão portuguesa no norte de África”, Ethnos 3: 319-345, designadamente na p. 338, onde este erudito enquadra o carácter de D. Henrique na sua época: "Um dos mais curiosos aspectos em que se pode surpreender o estado de espírito do cavaleiro-cruzado são os frequentes milagres e prodígios com que, segundo eles crêem, Deus os distingue". Também no Martyrium et Gesta... D. Henrique acredita firmemente na iminência de um portento divino que permita superar a inferioridade numérica. 


\section{ProyeCción POLÍTICA Y PEDAGÓGICA DEL prólogo a la Rethórica de Cicerón \\ Dedicado por Alfonso de Cartagena al infante D. Duarte}

Tomás González Rolán 
Es bien sabido que después del triunfo de Portugal sobre Castilla en la batalla de Aljubarrota (15- VIII-1385) se respiró un clima de tensión, enfrentamiento y desencuentro entre los dos reinos, sólo en parte mitigado por las treguas generales de 1402 y por la frágil paz de 1411, primer fundamento, según L. Suárez Fernández ${ }^{1}$ de la amistad hispano-portuguesa.

Un paso decisivo en esta dirección fue dado por Juan II al enviar, en 1421, una embajada a Portugal para responder a las que el monarca luso João I había mandado a Castilla en 1418 y 1419. La embajada castellana la componían un prestigioso letrado y jurista, el deán de Santiago Alfonso de Cartagena, futuro obispo de Burgos, y como secretario un noble llamado Juan Alfonso de Zamora, y su misión fundamental era la de entablar la discusión que propiciase la renovación y ratificación de la paz de 1411.

Las negociaciones no fueron fáciles, debido, por un lado, a las exigencias del monarca luso; y por otro, a la firmeza de los representantes castellanos, por lo que duraron mucho tiempo y obligaron a éstos últimos a permanecer en el país vecino en esta primera legación durante un año (diciembre de 1421- diciembre de 1422), y retornados a Castilla para que la tregua fuese firmada por Juan II, regresaron de nuevo después de

\footnotetext{
${ }^{1}$ Fernández, L. Suárez 1960: 37.
} 
Semana Santa de 1423 con el fin de que el acuerdo de paz fuese ratificado por el monarca portugués; volvieron de nuevo en 1424 permaneciendo en Portugal hasta 1425, y finalmente estuvieron en la Corte portuguesa en una cuarta legación entre 1426 y 1427.

La misión política llevada a cabo por Alfonso de Cartagena supuso un rotundo éxito, y en este sentido puede considerarse como un hito en la historia de los encuentros y acercamientos entre Portugal y Castilla en el siglo XV, pues no sólo logró que se firmase la tregua de paz de 1423 sino que propició la paz definitiva, firmada el 30 de octubre de 1431.

A su labor y logros como embajador en la Corte portuguesa se refiere Fernando del Pulgar $^{2}$ en su obra Claros varones de Castilla en los siguientes términos: "fue enbaxador al rey de Portugal por mandado del rey don Juan e, con fuerça de sus razones, escusó la guerra e concluyó la paz que por entonces ovo entre estos dos reinos".

Ahora bien, la ocupación política en defensa de los intereses del reino de Castilla y al servicio de la paz, la completó al establecer una estrecha y fructífera relación cultural no sólo con los miembros de la casa real, sino también con algunos escogidos intelectuales portugueses.

De sus conversaciones con Don Duarte, entonces heredero al trono lusitano, sobre la educación moral del hombre y la formación política de los gobernantes surgieron dos obras realizadas por Alfonso de Cartagena y dedicadas a este príncipe, una de las figuras cimeras,

${ }^{2}$ Pérez Priego, M. Á. (ed.) 2007: 188. 
junto con su hermano el Infante Don Pedro, de la cultura y política portuguesa de la primera mitad del siglo XV, a saber: la obra original titulada Memoriale virtutum, escrita en latín y finalizada en Azoia en el verano de 1422, y la traducción del De inventione de Cicerón, comenzada a petición de D. Duarte en 1424 y terminada algunos años después, posiblemente en 1431- 32. Y si la primera de las obras citadas trata de la ética y formación moral, la Rethórica de M. Cicerón, pues así se llama la traducción del De inventione, viene a completar el marco político del príncipe.

Pero en esta primera legación, no se limitó Alfonso de Cartagena a escribir las obras anteriormente citadas sino que, a petición ahora de su compańero de embajada, Juan Alfonso de Zamora, llevó a cabo la traducción de las obras ciceronianas ${ }^{3}$ De senectute y De officiis y completó el tratado del De casibus virorum illustrium de Boccaccio, dejado aparentemente sin terminar por el Canciller Ayala.

Sobre la influencia, o, si se quiere, la huella dejada por Alfonso de Cartagena en el ambiente intelectual de la corte de Joáo I, hay diversidad de opiniones, pues una historiadora como Isabel Beceiro Pita $^{4}$ sostiene que

"apenas parecen haber tenido eco en Portugal las versiones de Aristóteles, Cicerón y Séneca realizadas por Alonso de Cartagena, que constituyen el máximo exponente del acceso

${ }^{3}$ Cf. Morrás, María (ed.) 1996: 13- 27.

${ }^{4}$ Beceiro Pita, I. 1999: 221- 235, maxime 232. 
de la nobleza castellana a la filosofía clásica y aparecen, de forma reiterada, en las bibliotecas seńoriales de la época",

mientras que otro estudioso, Abdón M. Salazar, en un conocido y muy citado estudio ${ }^{5}$ equipara, sin duda de forma exagerada, el papel de Cartagena en Portugal "difundiendo el entusiasmo por la cultura clásica en Lusitania”, con el que ejerció el bizantino Crisolaras en la Italia de comienzos del Cuatrocientos "diseminando el ideal de la paideia griega entre los latinos".

Ahora bien, ni I. Beceiro Pita ni Abdón M. Salazar han justificado por qué la sabiduría de Alfonso de Cartagena influyó o dejó de influir en la orientación y proyección hacia el Humanismo de la corte portuguesa, tarea que ya en 1925 reclamaba Joaquín de Carvalho ${ }^{6}$, quien refiriéndose a la traducción de la Rethórica dedicada a D. Duarte y antes de reproducir parte del Prólogo, afirmaba que "como fonte da cultura da corte de D. Duarte, merecem transcrever-se o prefácio e a introdução do bispo de Burgos, cujas relações com Portugal exigem um estudo especial”.

El estudio especial de las relaciones de Cartagena con la cultura portuguesa no ofrece, como pensaba Abdón M. Salazar, una sola dirección, a saber, la que lleva de Cartagena a los miembros de la casa real y a los intelectuales portugueses, sino también la recíproca, la que parte de estos últimos y alcanza al eminente letrado y jurista castellano.

${ }^{5}$ Abdón M. Salazar 1976: 215- 226, maxime 217.

${ }^{6}$ Carvalho, Joaquim de 1925: 114-140, maxime 128- 129. 
En efecto, se considera de una gran importancia en la propia orientación cultural de Cartagena el contacto mantenido con un selecto grupo de intelectuales portugueses, que habían estudiado en Bolonia ${ }^{7}$, pues por medio de ellos en el último viaje oficial a Portugal tuvo la oportunidad de conocer varias versiones latinas de textos griegos realizadas por Leonardo Bruni, a saber, los discursos a favor y en contra de Tesifón de Esquines y Demóstenes, respectivamente, y el tratado de San Basilio sobre la lectura de los libros de los gentiles, hecho que el propio Cartagena nos relata en el prólogo de su Liber en la famosa Controversia con el propio Bruni ${ }^{8}$.

$\mathrm{Si}$, como bien ha señalado Adeline Rucquoi ${ }^{9}$, la imagen que se desprende de obras como el Memoriale virtutum y la Rethórica "montre les castillans comme les maitres...de jeunes princes portugais dont les talents dans ces domaines ont frappé leurs interlocuteurs", no es menos cierto que "ces 'maîtres' castillans ont souvent a leur tour appris du Portugal et des Portugais", por lo

${ }^{7}$ Cf. Costa, A. D. de Sousa 1990: 559- 658; Rau, V. 1969: 185206; Idem 1973: 7-28; Bettini, C. 2008: 205- 226. La profesora Nair de Nazaré Castro Soares, en un importante estudio titulado (2002), "O Infante D. Pedro e a cultura portuguesa", Biblos 78: 107-128 [ maxime 112], afirma que fue de gran significado en la definición de los ideales culturales "a influência directa da Itália em Portugal, pelo menos a partir do início do século XIV. Conhecida é a presença de letrados portugueses em Itália entre 1350 e 1450 e o papel desempenhado pelo abade D. Gomes, geral da ordem camalduense e núncio e visitador apostólico dos mosteiros de Portugal, figura de grande prestígio em Florença”.

${ }^{8}$ Cf. T. González Rolán, T. - Moreno Hernández, A. - Saquero Suárez- Somonte, P., 2000: 194- 205.

${ }^{9}$ Rucquoi, A. 2003: 39- 51, maxime 43. 
que a su parecer, que compartimos, "il y a donc une sorte d'egalité dans l'échange".

Respecto a la opinión de I. Beceiro Pita de que apenas parecen haber tenido eco en Portugal las versiones de Aristóteles, Cicerón y Séneca realizadas por Alfonso de Cartagena, ya hemos adelantado que nos parece que no ha sido debidamente justificada, lo que ocurriría si hubiese hecho un detenido cotejo de dichas versiones con distintas obras, bien de los príncipes $\mathrm{D}$. Duarte y D. Pedro, bien de otros intelectuales o literatos portugueses.

Pero antes de abordar este cotejo, el estudio de las relaciones de Cartagena con la cultura portuguesa exige un conocimiento textual y filológicamente exacto de las obras dedicadas a Don Duarte o al menos de los interesantísimos prólogos tanto de la versión original latina, todavía inédita, del Memoriale virtutum, que se nos ha transmitido por medio de cinco testimonios manuscritos ${ }^{10}$, como de la Rethórica, editado con demasiados errores de transcripción por el gran filólogo español Marcelino Menéndez Pelayo ${ }^{11}$ o con significativos defectos por Rosalba Mascagna ${ }^{12}$, razón por la que como apéndice del presente trabajo incluimos una nueva edición de este interesantísimo texto reproduciendo con exactitud ${ }^{13}$ los folios $1^{\mathrm{r}}-5^{\mathrm{r}} \mathrm{del}$

${ }^{10}$ Cf. Campos Souto, M. 2004: 149- 156.

${ }^{11}$ Menéndez Pelayo, M. 1962: 307- 313.

12 Mascagna, Rosalba 1969.

13 Respetamos las particularidades ortográficas y lingüísticas del manuscrito escurialense, si bien hemos introducido algunas regularizaciones de acuerdo con los usos actuales del castellano en 
manuscrito de El Escorial T.II.12, único testimonio que se nos ha conservado de la versión castellana del De inventione ciceroniano realizada por Alfonso de Cartagena a petición del infante Don Duarte.

Una vez establecidos los textos de estas dos obras, el siguiente paso sería comprobar en qué medida han podido influir en la composición del Leal Conselheiro, obra original del propio dedicatorio, Don Duarte, ahora rey de Portugal.

Por lo que se refiere al tratado latino sobre las virtudes, el propio Don Duarte en el capítulo L de su mencionada obra ${ }^{14}$ cita una serie de libros que él ha leído, obran en su poder y han sido tenidos en cuenta a la hora de escribir sobre la prudencia, justicia, templanza y fortaleza, y entre ellos se encuentra el "Memorial das Virtudes que das Heticas d'Aristotilles me ordenau o adayam de Sanctiago", es decir, el Memoriale virtutum, primera de las obras escritas por Cartagena en dos libros, cuyos prólogos y epílogo están dedicados al Infante portugués.

El alcance de la presencia del Memoriale en el Leal Conselheiro no debió ser pequeño, si hacemos caso de lo que nos dice Abdón M. Salazar ${ }^{15}$

lo que se refiere al uso de mayúsculas y minúsculas, a la separación de palabras y al uso de acentos. Sólo en unos pocos casos hemos introducido conjeturas para remediar pequeños errores del copista o para completar términos desaparecidos o que se leen con dificultad a causa de pequeños deterioros producidos en el cuerpo del texto.

${ }^{14}$ Citamos por la edición clásica de Joseph M. Piel 1942: $207-$ 208; cf. también la edición más moderna de Castro, María Helena Lopes de 1999: 200.

${ }^{15}$ Salazar 1976: 223. 
"Compuesto, sin embargo, en diversas épocas de su vida el Leal Conselheiro, dedicado a la reina Leonor de Aragón, debe mucho, en todo caso, a Cartagena y a sus contertulios este amasijo interesante pero heterogéneo...Y dado el objeto específico intentado por el Infante, el estudio de los matices morales anejos al ejercicio de la lealtad, teniendo en cuenta las funciones de las facultades, y las de la voluntad en especial, está claro que el Memoriale virtutum iba a servirle como anillo al dedo para los 98 capítulos de la Parte I”.

No es el momento para afirmar o negar el aserto de Abdón M. Salazar, cuestión que abordaremos junto con la edición crítica y análisis de los dos prólogos y epílogo del Memoriale dedicados a D. Duarte. Lo que nos interesa ahora es detenernos en la obra de Rethórica ciceroniana, traducida por encargo de D. Duarte y cuyo prólogo le fue brindado.

Así como se cita el Memoriale virtutum, como hemos indicado anteriormente, no hay mención alguna en el Leal Conselheiro ni del De inventione ni de la traducción deAlfonso de Cartagena. Con todo, es posible descubrir puntos en común y evidentes coincidencias entre las ideas sobre la traducción apuntadas en el prólogo y los cinco "avysamentos" para traducir bien del latín al romance portugués ("lynguagem”) que aparecen descritos en el capítulo XCIX del Leal Conselheiro.

Respecto a Cartagena, si se analiza en profundidad su labor como traductor de Cicerón primero y más tarde de Séneca, como teórico de la traducción en su 
Liber o Tratado contra Leonardo Bruni ${ }^{16}$, así como sus reflexiones en algunos prólogos, entre los que destacamos el de la Rethórica ofrecido a D. Duarte, se nos presenta como uno de los más antiguos precursores hispanos de la moderna teoría de la traducción, al plantear el problema de ésta como actividad diferenciada según el tipo de textos de que se trate.

Pero Alfonso de Cartagena no se contenta con marcar la línea divisoria que separa la traducción técnica de la literaria, sino que va mucho más allá del análisis onomasiológico de las traducciones para adentrarse en un serio y profundo examen semasiológico de los términos pertenecientes a los lenguajes literario y científico-técnico.

En efecto, así como en la lengua de partida los términos utilizados en los textos literarios y científicos son semánticamente distintos, en el primer caso caracterizados por ser polísémicos y sinónimos de muchos otros de la lengua, en el segundo por todo lo contrario, es decir, por mantener una relación biunívoca y exclusiva con el concepto señalado, Cartagena, piensa, $y$ en este sentido se nos presenta como un estudioso de una extraordinaria penetración, que la traducción literaria puede servirse de términos polisémicos y sinonímicos de la lengua de llegada, lo que no es posible al traductor de textos científicos, pues habrá de usar verba restricta et propriissima, es decir, palabras caracterizadas por su exactitud, concisión y biunivocidad entre la forma y el contenido, y si la lengua de llegada carece de

${ }^{16}$ Cf. González Rolán et alli 2000: 117- 140. 
esas palabras, le estará permitido al traductor, opina con toda razón Cartagena, recurrir al préstamo lingüístico o proceder a la transcripción del vocablo del original.

En la traducción de las obras que no consideraba científico-técnicas no sólo se contentó con llevar a la práctica un método de traducir, el de la conversio ad sententiam, sino que también se ocupó, como podemos observar en la Rethórica de editar cuidadosamente la obra traducida, dividiendo cada uno de los dos libros en títulos, éstos en capítulos, y añadiendo explicaciones y llamadas marginales.

Por otra parte, Cartagena es consciente de que una de las exigencia de la traducción ad sentenciam ("siguiendo el sseso más que las palabras") es traer al autor al lenguaje del lector, otra el de ser fiel al sentido del original sin preocuparse en demasía por los cambios que se produzcan al nivel de los verba, otra, en fin, es conseguir que el texto traducido no sea oscuro, es decir, que "sin trabajo lo pueda entender quien leer lo quisiere" y que mantenga "grant parte del dulçor" del original.

Pues bien, como justamente ha puesto de relieve Aires A. Nascimento en varios y penetrantes trabajos ${ }^{17}$, en la formulación de las cinco reglas o principios planteados por D. Duarte hay

dados que facilmente se deixam aproximar senão mesmo identificar com as reflexóes e com a prática de Cartagena.

${ }^{17}$ Nascimento 1993: 265- 287; Idem 1997: 113- 138; Idem 1999: 41- 70. 
Num dos conselhos finais em que se sugere a colaboração entre dois agentes de tradução parece retratarse a actuação do bispo de Burgos com o seu secretário Juan Alonso de Zamora (com quem executava as traduçóes, ditando um e escrevendo o outro).

Entrevê-se também a própria linguagem do burgalês no procurar um resultado onde prevaleça a clareza, a formosura, a brevidade, através de operaçóes específicas. A insistência no rigor da linguagem e no decoro da mesma são também conteúdos que se registam em Alonso". 18

Así pues, los principios sobre el hecho de traducir en los que se apoya Don Duarte (fidelidad al original, purismo del lenguaje, pertinencia y propiedad de los términos, decoro moral y claridad de exposición) tuvieron su fuente de inspiración en los escritos y charlas de Cartagena, de manera que incluso una de las preocupaciones de éste último, a saber, la de editar y no solamente traducir los textos aparece también en el quinto 'avyamento' del Infante portugués: “E pera esto aproveita muyto parragrafar e apontar bem”.

Este capítulo 99 del Leal Conselheiro nos muestra, por una parte, que el antiguo 'discípulo' de Cartagena ha demostrado un deseo de perfección que le ha llevado a superarse a sí mismo e incluso al propio maestro, proponiendo nada más ni nada menos que unas reglas generales sobre cómo traducir los textos latinos al romance portugués; por otra, que para el príncipe Don Duarte toda teoría debe ir acompañada de la práctica,

${ }^{18}$ Idem 1997:136- 137. 
que queda reflejada en las dos traducciones, en verso y prosa, que propone de otros tantos textos latinos.

El gran pensador y filólogo George Steiner ${ }^{19}$ comentando el esfuerzo de los hombres por lograr en la traducción un compromiso entre 'letra' y 'espíritu', entre 'palabra' y 'significado', cita como pioneros modernos a los franceses Etienne Dolet (Manière de bien traduire d'une langue en autre, de 1540) y Pierre-Daniel Huet (De interpretatione, de 1680), pues, según él, "no por azar los franceses están a la cabeza en lo que concierne a la teoría de la traducción durante esta época" (= siglos XVI y XVII).

Respecto al primer autor, indica que: "los cinco mandamientos del traductor que enuncia Dolet bien podrían remontarse a los gramáticos y retóricos italianos de principios del siglo XVI y, concretamente, hasta Leonardo Bruni".

Si se comparan los cinco "avysamentos" de D. Duarte y los cinco mandamientos de E. Dolet, a pesar de mediar entre ellos una distancia de más de cien ańos, se observan tantos puntos en común que nos inclinarían a pensar que las ideas sobre la traducción de autores peninsulares como Alfonso de Cartagena, Alfonso de Madrigal (El Tostado) y por supuesto el príncipe heredero de Portugal anticipan ideas que luego enarbolarían como suyas los franceses.

No podemos detenernos más sobre esta cuestión, pues debemos apuntar otro interesante aspecto que se puede deducir de los prólogos dedicados por Cartagena

${ }^{19}$ Steiner 1981: 300- 301. 
a D. Duarte. En un breve pero muy enjundioso estudio ${ }^{20}$ Luis Adão da Fonseca ha puesto de manifiesto la necesidad que la dinastía de Avis, iniciada por João I, tuvo de reivindicar para todos sus miembros el carácter de dinastía mesiánica, caracterizada por la ejemplaridad moral de los valores que encarnaban (unión, sabiduría, virtud, deseo de perfección, etc.).

Respecto de Don Duarte, el citado autor ${ }^{21}$ afirma que parece "ter sido este monarca quem iniciou o proceso de construção ideológica do modelo de exemplaridade da família real portuguesa”.

Si esto es así, este proceso no comenzaría, como sostiene Adáo da Fonseca, tras la muerte de João I sino mucho antes, después de la llegada de Alfonso de Cartagena a Portugal, pues él contribuyó no sólo a formar a los hijos mayores del rey sino también a extender, por medio de sus prólogos, la fama, por otra parte bien merecida, de su virtud, sabiduría, inteligencia y deseo de perfección.

${ }^{20}$ Fonseca 2003: 53-61.

${ }^{21}$ Idem, ibidem: 59. 


\section{Anexo I \\ (MANusCrito DE El Escorial, Signatura: T. II. 12)}

/f.1\%/Libro de Marcho Tullio Çiçeron que se llama de la Retórica trasladado de latín en romançe por el muy reuerendo don Alfonso de Cartajena obispo de Burgos a ynstançia del muy esclaresçido prínçipe don Eduarte rey de Portogal

\section{Prólogo en la traslaçión}

Fablando con vos, prínçipe esclaresçido, en materias de sçiençia en que vos bien sabedes fablar, en algunos días de aquel tiempo en que en la vuestra corte por mandado del muy cathólico Rey, mi sseñor, estaua, vino-vos a voluntad de auer la arte de la Rethórica en claro lenguaje, por conosçer algo de las doctrinas que los antiguos dieron para fermoso fablar; e mandástesme, pues yo a esa sazón paresçía aver algunt espaçio para me ocupar en cosas estudiosas, que tomase vn pequeńo trabajo e pasase de latýn en nuestra lengua la Rethórica que Tullio conpuso.

E comoquier que en el estudio d'ella fuy yo tan poco ocupado e despendí tan poco tienpo que, non digo para la trasladar mas aun para entender algo d'ella, me reputaua e reputo ynsufiçiente, pero, acatando al vuestro studioso deseo, començé a poner en obra vuestro mandamiento.

E, començando ocupar en ello la péñola, 
ssobrevino mi partida e quedó a vos, segunt se suele fazer $/ \mathrm{f} .1^{\mathrm{v}} / \mathrm{r}$ en las compras, como por manera de sseñal, una muy pequeña parte del comienço e vino comigo el cargo de lo acá conplir.

E pasaron después tienpos asaz, en que otra obra mucho mayor e de más trabajo e estudio se podiera acabar; mas ésta non se acabó fasta aquí, çierta mente non por oluido nin por menos preçio -ca lo primero fuera torpeza muy grande, lo segundo inmensa presunçión- mas por sobrevenir tales tienpos que a los semejantes estudios otorgaron ferias noctorias; lo qual para mi escusaçión allegar non sé por quales otras mejores nin tan buenas palabras que por aquellas que escrivió sant Bernardo al papa Eugenio en el libro De la consideraçión, diziéndole así:

Membrándome del prometimiento en que so obligado a ty, o muy buen varón papa Eugenio, quiérome librar, siquiera tarde; e vergüença avría yo de la dilaçión si sopiese que en mí ouiera negligençia o menospreçio. Pero non es así, mas sobrevino, commo tu sabes, tienpo graue, tal que al huso de la vida paresçía enbargar quanta más a los estudios.

E parésceme que puedo a propósito dezir algo de lo semejante -non porque entiendo que vino a uos tanta graueza de tienpo commo a él por ventura vino, nin que la presente traslaçión sea de tanto estudio nin requiera tanto trabajo commo la compusiçión que él fazía; mas nin el yngenio e sçiençia de quien esto escriue es egual por çierto, nin ha proporçión nin respecto con la de aquel santo e famoso varón. E así non es de marauillar 
que pequeño /f. $2^{\mathrm{r}} /$ yngenio en la pequeña obra con menor inpedimento tanto se enbargue, commo el grande en la obra más alta por el ynpedimento mayor.

Por ende la tardança que en esto ouo, si la afeçción non me engaña, que suele defender las culpas proprias, non es mucho de culpar. $\mathrm{Ca}$, ocupado nuestro muy ýnclito prínçipe en su graçiosa juventud contra una parte de sus vezinos en defensión de su honor real e anparo de la su república, e contra otra en exaltaçión de la santa fee cathólica e opresión de los enemigos de la vera Cruz, que dentro de los nuestros términos tanto tienpo ha que moran, razonable cosa es que todos sus súbditos, dexadas las otras cosas en que en los otros tienpos se suelen ocupar, bueluan su coraçón enteramente e ocupen su voluntad poniendo su poderío, en quanto el estado e fuerça de cada vno basta, para le en ello seruir.

Pero, entre las otras ocupaçiones, tomé algunt poco espaçio para conplir vuestro mandado e pagar ya esta debda e, llamada la ayuda diuinal, fízelo así como vedes, non tal sin dubda commo fazer se deuía e pertenesçía enbiar a vos a quien se dirige, mas commo la inbeçilidat e flaqueza del yngenio del escriuiente en ta<nto $>$ bastó; confiando en vuestra virtuosa equanimidat que rescebiredes benignamente esta paga, aunque tarde, e tollerando los defectos que en la presente traslaçión fallaredes, donde tollerar se podieren e hemendándolos donde hemendar se deuieren.

E para más clara ver la intençión, ante que oyades a Tullio, oyd la introduçción siguiente /f. $2^{\mathrm{v}} /$ : 


\section{Introducción}

Muchos fueron los que de la rethórica en los tienpos antiguos fablaron, así griegos como latynos. Pero avnque de la eloquençia de asaz d'ellos oy dura la fama e de algunos sus famosas oraçiones, -así commo entre los griegos de Demosten<e >s e de Eschines e entre los latinos de Salustio- e de otros más libros conpuestos de la arte liberal mesma que llaman rethórica, yo non sé que de aquellos muy antiguos en este tienpo parescan, si non de dos actores: el uno griego, el otro latino.

El griego fue Aristotiles, que fabló en ello profundamente: ca non entendió aquel philósopho que del todo acabaua la obra moral, si después de las Éthicas e Políticas non diese doctrinas de lo que a la eloquençia pertenesçe, e conpuso vn libro que se llama de la Rethórica, en que escriuió muchas e nobles conclusiones pertenesçientes a esta arte, de las quales, así por theólogos commo por juristas, son muchas <e en di>versos logares allegadas, cada una a su propósito.

El otro fue latino e éste es Marcho Tullio Çiçerón el qual escriuió muchos libros e tractados de diversas materias, escriptos sso muy eloquente estilo. E entre ellos conpuso algunos pertenesçientes a la doctrina d'esta arte. Ca, aunque en todos guardó él bien las reglas de la eloquençia, pero non fabló en todos d'ella; ca una cosa es fablar segunt la arte e otra es fablar de la arte. E él en todos guardó la arte; pero non en todos mas en algunos fabló de la arte. Éstos si sson /f. $3^{\mathrm{r} / \text { muchos }}$ o quántos son, non lo sé, mas los que común mente 
parescen son los siguientes: el libro de la Rethórica vieja e otro de la Rethórica nueva e un libro que dizen del Orador e otro del Orador menor e un breve tractado que se llama De la muy buena manera de los oradores e otro que se yntitula la Tópica; los quales, avnque por diuersas maneras, todos tienden a dar doctrinas de la eloquençia. E d'estos, porque el de la Rethórica vieja es primero e avn porque fabla más largo, fue por vos escogido para que se posiese en nuestro lenguaje, e fízose así por vuestro mandado.

En la traslaçión del qual non dubdo que fallaredes algunas palabras mudadas de su propria significaçión e algunas añadidas, lo qual fize cuydando que conplía así; ca non es, éste, libro de Santa Escriptura en que es herror añader o menguar, mas es conposiçión magistral fecha para nuestra doctrina. Por ende, guardada quanto guardar se puede la yntençión, aunque la propriedat de las palabras se mude, non me paresce cosa ynco $<$ n>ueniente; ca, commo cada lengua tenga su manera de fablar, si el ynterpretador sigue del todo la letra, nescesario es que la escriptura sea obscura e pierda grant parte del dulçor. Por ende, en las doctrinas que non tienen el valor por la abtoridat de quien las dixo nin han sseso moral nin míxtico, mas solamente en ellas se cata lo que la sinple letra significa, non me paresçe dapńoso retornar la yntençión de la escriptura en el modo del fablar que a la lengua en que se pasa conviene. La qual manera de trasladar aprueua aquel singular trasladador, sant Geronimo, en una solepne epístola que se sobreescrive De la muy buena manera 
/f. $3^{v} /$ del declarar, que enbió a Pamachio, entre otras cosas diziéndole así:

Yo non solamente lo digo, mas aun con libre boz lo confieso, que en la ynterpretaçión de los libros griegos non curo de exprimir vna palabra por otra mas sigo el sseso e efecto, saluo en las Santas Escripturas, porque allí la horden de las palabras trae mixterio.

E esta manera seguí aquí porque más sin trabajo lo pueda entender quien leer lo quisiere; e aun por lo más aclarar, commoquier que en latin está todo junto e non tiene otra partiçión saluo la de los libros -es a saber entre el primero e segundo- pero yo partý cada libro en diversos títulos e los títulos en capítulos según me paresçió que la diversidat de la materia pidía. E donde el vocablo latino del todo se pudo en otro de romançe pasar, fize-lo; donde non se pudo buenamente por otro canbiar, porque a las vezes una palabra latina requiere muchas para se bien declarar e si en cada logar por ella todas aquéllas se ouiesen de poner farían confusa la obra, en el tal caso al primero paso en que la tal palabra ocurrió se fallará declarada. E, aunque después se aya de repitir, non se repite la declaraçión, mas quien en ella dubdare retorne al primero logar donde se nonbró, el qual está en los márgines señalado, e verá su significaçión.

Pero, aunque esto todo se faga, las conposiçiones que son de sçiençia o de arte liberal, para bien se entender, todavía piden estudio porque non consiste la dificultad de la sçiençia tan sólo en la obscuridat del lenguaje, ca si 
así fuese, los buenos gramáticos entenderían qualesquier materias que en latín fuesen escriptas: e /f. $4^{\mathrm{r}} /$ veemos el contrario, ca muchos bien fundados en la arte de la gramática entienden muy poco en los libros de theología e de derecho e de otras sçiençias e artes, aunque son escriptas en latýn, ssy non ouieron doctores d'ellas que los enseñasen. Por ende, aunque esta Rethórica sea traspuesta en llano lenguaje, quien entenderla quisiere cunple que con actençión la lea.

E demás d'esto, es de saber que algunos cuydan que la rethórica toda consiste en dar dotrinas espeçiales para escrivir o fablar o trasmudar o hordenar las palabras, mas non es así; ca, commoquier que d'ella sale la buena hordenança del fablar, pero non es éste su total yntento, ca grant parte d'ella se ocupa en enseñar cómmo deuen persuader e atraer a los juezes en los pleitos e otras contiendas e a las otras personas en otros fechos, quando acaescen.

E quien bien lo quisiere considerar, fallará que el ofiçio que entre nos tienen los juristas que llamamos abogados, ése era prinçipalmente el de los rethóricos antiguos; e lo que éstos oy quieren fazer allegando testos e determinaçiones, los otros fazían diziendo razones fermosas, cada vno en favor de su parte, e a las vezes inserir aquellas pocas leys que entonçe auía. Lo qual bien puede ver quien las famosas oraçiones de aquellos tienpos leyere; ca aquellas dos que en Athenas se fizieron, que ouieron tanta nonbradía que Tullio mesmo les conosce ventaja e sant Gerónimo faze d'ellas en el prinçipal prólogo de la Biblia mençión, la vna fizo 
Echines acusando a Thesifón, la otra Demosten $<\mathrm{e}>\mathrm{s}$ defendiendo al acusado e reacusando al acusador. E muchas de las que de Tullio leemos son fechas acusando a unos e $/ \mathrm{f} .4^{\mathrm{v}} /$ defendiendo a otros, como fazen los abogados solepnes. Por ende quien lo presente leyere non cuyde que fallará escripto cómmo escriua las causas nin cómmo trasporte las palabras: ca, aunque d'ello otros más modernos en tienpo e non de tan alta manera algo escriuieron, pero los prínçipes de la eloquençia e los preçipuos escriptores d'ella en los prinçipales libros non se ocuparon del todo en esto mas dieron sus generales doctrinas para arguyr e responder, para culpar e defender e para mouer los coraçones de los oyentes a sańa o a misericordia o a las otras pasiones que en la voluntad humana cahen; e dende cada uno saque por su yngenio aquello que entendiere que para en lo que quiere fablar cunple.

E d'esto Aristotiles en el libro que deximos fabló muy profunda e sçientíficamente; e Tullio en éste non con tanta sçiençia, mas por más clara e más particular hordenança, dixo algunas cosas notables que del otro tomó e aun añadiendo de suyo -entre las quales hay algunas que, si bien entendidas e a buen fin traýdas son, pueden mucho aprouechar; e si con maliçiosa intençión d'ellas se husa, podrían algo dapñar, mas nin por esto son de dexar; ca el fierro non es de dexar, aunque con él se cometen a las vezes ynjustos omeçidos e muertos a mala verdat, porque las armas fechas d'él aprovechan ha esforçar la justiçia e ha justa defensión de la república e opresión de los ynjustos e malos. 
Nin las doctrinas del especulador e de los otros juristas práticos son de menospreçiar porque con éllas los malos abogados fazen muchas cauilaçiones, pues los buenos ¿dónde toman mucho avisamiento para guiar la justicia /f. $5^{\mathrm{r}} / \mathrm{e}$ oviar a las maliçias que contra ella se tienen?

Por ende, a buen fin e con recta e sana yntençión oyamos ya qué dize Tullio. 


\section{Bibliografia}

Beceiro Pita, I. (1999), "La Recepción de la cultura aristocrática castellana en el Portugal de los Avis", Estudios - Letras 1: 221- 235.

Bettini, Clelia (2008), “Tre Valascos nell'Italia del Quattrocento: Meser Valasco di Vespasiano da Bisticci, Petrus Vallascis di Cataldo Sículo e Vasco Fernandes de Lucena”, Humanitas 60, 2008: 205-226.

Campos Souto, M.(2004), Memorial de virtudes: la traducción castellana del Memoriale virtutum de Alfonso de Cartagena, Burgos, Instituto Municipal de Cultura.

Carvalho, Joaquim de (1925), "A erudição de Gomes Eanes de Zurara (Notas em torno de alguns plágios deste Cronista)", Boletim bibliográfico da Biblioteca da Universidade de Coimbra 7: 114-140.

Castro, María Helena Lopes de ed. (1999), Dom Duarte, Leal Conselheiro. Edição crítica, introdução e notas (prefácio de Alfonso Botelho). Lisboa.

Costa, A. D. de Sousa, O.F.M. (1990), Portugueses no Colégio de S. Clemente e Universidade de Bolonha durante o século XV, vol. I, Bolonia, Publicaciones del Real Colegio de España.

Fonseca, Luis Adão da (2003), "Política e cultura nas relaçóes luso-castelhanas no século XV", 
Peninsula. Revista de Estudos Ibéricos, no 0: 53- 61.

González Rolán, Tomás. - Moreno Hernández, A. - Saquero Suárez- Somonte, Pilar (2000), Humanismo y Teoría de la Traducción en España e Italia en la primera mitad del siglo XV. Edición y estudio de la Controversia Alphonsiana (Alfonso de Cartagena vs. L. Bruni y P. Candido Decembrio), Madrid, Ediciones Clásicas.

Marcelino Menéndez Pelayo, Marcelino (1962), Historia de las Ideas Estéticas en España, Madrid: 489- 494.

Marcelino Menéndez Pelayo, Marcelino (1950), Bibliografía Hispano- latina Clásica, vol. II, Santander, 1950.

Morrás, María (ed.) (1996), Alonso de Cartagena. Libros de Tulio: De senectute, De los Ofiçios. Edición, prólogo y notas, Alcalá de Henares: Universidad.

Nascimento, Aires A. (1993), "As livrarías dos Príncipes de Avis", Biblos 69 (Actas do Congresso Comemorativo do $\sigma^{\circ}$ Centenário do Infante $D$. Pedro: 25 a 27 de Novembro de 1992): 265- 287.

Nascimento, Aires A. (1997), "Traduzir, verbo de fronteira nos contornos da Idade Média”, in $O$ género do texto medieval, Cristina Almeida Ribeiro - Margarida Madureira (coords.), Lisboa: 113-138.

Nascimento, Aires A. (1999), “Os textos clássicos em 
período medieval: tradução como alargamento de comunidade textual", in Raizes greco-latinas da cultura portuguesa. Actas do I Congresso da APEC, Coimbra: $41-70$.

Pérez Priego, Miguel Ángel (ed.) (2007), Fernando del Pulgar, Claros varones de Castilla, Madrid, Cátedra - Letras Hispánicas.

Piel, Joseph M. ed. (1942), Leal Conselheiro o qual fez Dom Eduarte rey de Portugal e do Algarve e Senhor de Cepta. Edição critica e anotada. Lisboa.

RAU, Virgínia (1969), "Italianismos na cultura jurídia portuguesa do século XV", Revista Portuguesa de História 12: 185- 206.

Rau, Virgínia (1973), "Studenti ed eruditi portoghesi in Italia nel secolo XV", Estudos Italianos em Portugal 36: 7-28.

Rosalba Mascagna (1969) Alfonso de Cartagena, La Rethórica de M. Tullio Ciceron. Liguori-Napoli.

RuCQuoI, Adeline (2003), "Rois et princes portugais chez les auteurs castillans du XVème siècle", Peninsula. Revista de Estudios Ibéricos (Entre Portugal e Espanha. Relaçôes Culturais (séculos XV-XVIII). In Honorem Jose Adriano de Freitas Carvalho), no 0: 39- 51.

Salazar, Abdón M. (1976), "El impacto humanístico de las misiones diplomáticas de Alonso de Cartagena en la Corte de Portugal entre Medievo 
y Renacimiento (1421- 1431)”, Medieval Hispanic Studies presented to Rita Hamilton, in A.D. Deyermond (ed.), Londres, 215- 226.

Soares, Nair N. Castro (2002), "O Infante D. Pedro e a cultura portuguesa”, Biblos 78: 107-128.

Steiner, George (1981) Después de Babel. Aspectos del lenguaje y la traducción, México -Madrid - Buenos Aires, Fondo de Cultura Económica.

SuÁrez Fernández, L. (1960), Relaciones entre Portugal y Castilla en la época del Infante Don Enrique, 1399-1460, Madrid, Consejo Superior de Investigaciones Científicas. 


\title{
RETÓRICA E RES PUBLICA NO RENASCIMENTO Da ELOQUÊnCIA NASCEU A CIDADE
}

\author{
Margarida Miranda
}


In principio erat sermo... (Jo.1.1 em trad. de Erasmo)

0. O uso vulgar dado hoje em dia ao termo 'retórica' traz ainda consigo uma conotação depreciativa de exercício escolar e formalista. Por detrás desta ideia popular, recorda Paul Oskar Kristeller (1982: 283), está a opinião, que remonta ao romantismo, de que não existem regras válidas para falar ou escrever bem.

Tal opinião não é mais do que reacção pouco racional à autoridade omnipresente dos clássicos e ao processo de codificação retórica que a Europa foi reelaborando durante o Renascimento e o Barroco. Retomo, pois, como Kristeller (1982: 284), os significados originais de retórica, em uso antes do século XIX, de si já dotados, desde a Antiguidade, de vários sentidos, conotaçóes e associações.

"Como teoria do discurso era um instrumento da política e da prática judicial. Como teoria do debate, relaciona-se com a lógica e com a dialéctica. Como uma teoria da composição em prosa, tinha nexos íntimos com a poética e a crítica literária. A retórica incluía a gramática bem como a teoria e a prática da historiografia. Como despertava as paixóes e recorria a sentenças morais, relacionava-se com a ética e muitas vezes afirma-se que era uma filosofia. Como programa de instrução avançada, foi durante séculos, rival, 
e muitas vezes rival vencedora, da filosofia e das ciências. E mesmo hoje, apesar do romantismo, os seus interesses não se extinguiram, de modo algum (...). Onde desapareceu o nome da retórica, a matéria sobrevive, com outras designaçóes (...)."

Embora náo possamos de modo algum aceitar a ideia de que o Humanismo renascentista corresponde a um modo de pensar único, pois trata-se, na verdade, de uma realidade muito ampla e complexa, que conta com demasiados contributos pessoais para que possamos defini-la por um conjunto de ideias comuns, creio, ainda assim, ser possível e desejável, não sem o risco de inevitáveis generalizaçóes, estabelecer algumas características distintivas da retórica tal como a recuperaram os homens do Renascimento, principalmente aquelas que deixam mais evidentes as relaçôes entre a retórica e a vida cívica e política.

Como náo podia deixar de ser, todas essas características se congregam em torno da tradição clássica, absorvida agora na sua integralidade (sobretudo após a descoberta de inúmeros manuscritos de obras clássicas) e levada ao maior esplendor.

De entre toda a tradição clássica, o autor cujo pensamento e biografia mais influenciou a retórica do Renascimento foi Cícero. Dele partirei, pois, sumariamente, antes de iniciar o trabalho descritivo que me propus, para concluir, enfim, quanto esta retórica 'reformada' foi tributária da obra e do exemplo do orador latino e, ao mesmo tempo, noção operacional de cultura e factor de desenvolvimento da sociedade contemporânea. 
Proponho, assim, um estudo propedêutico que consistirá numa síntese de uma época de ouro para a retórica clássica, como foi a época do Renascimento, na esperança de que ele seja útil, antes de mais, a quem procurar iniciar-se no estudo do humanismo renascentista.

1. No seu tratado De Inuentione, Cícero tece o elogio da eloquência e da sua utilidade humana. A eloquência é parte integrante da ciência política (I.6), pois tem por ofício dizer adequadamente para persuadir. Cícero não esquece, porém, que essa arte pode ser um bem ou um mal, por falta de sabedoria (I. 1 e 4). Neste tratado, Cícero manifesta, pois, uma nítida preocupação por que o poder da palavra seja correctamente usado. Ele sabia que a eloquência, assim como podia fundar cidades ou extinguir guerras e firmar alianças, podia de igual modo semear discórdias e provocar grandes calamidades entre os homens (I. 1). A sabedoria sem eloquência de pouco aproveita às cidades, mas a eloquência sem sabedoria prejudica-a; nunca lhe é útil:

sapientiam vero sine eloquentia nimium obesse plerumque, prodesse numquam... "Por isso, aquele que se arma de eloquência, de modo a (...) combater pelos interesses da pátria será um homem utilíssimo, tanto para as suas causas como para as causas públicas, e cidadáo amicíssimo (ibidem)."

Singular é a narrativa que Cícero faz da origem imaginária da eloquência como um bem (I.2). No livro 
I do De Inuentione, o jovem Cícero apresenta-nos uma interessante alegoria das origens da vida em sociedade, segundo a qual um homem sábio e eloquente se transformara no fundador do direito e no criador das cidades, capaz de elevar a humanidade dispersa e de converter em civilização a barbárie.

No princípio, o homem vivia entregue à natureza, vagueando pelos campos como os animais, sem conhecer a razão, nem o dever, nem o direito, nem a justiça, sujeito ao erro, à ambição e à ignorância ("cega e temerária dominadora do ânimo"), sem mais recursos que a força do seu própria corpo. Foi então que um certo varão, grande e sábio, se apercebeu de quanta capacidade havia nos homens para coisas maiores, se alguém ousasse ocupar-se deles para os tornar melhores. Logo reuniu num mesmo lugar aqueles que andavam dispersos pelos campos, ocultos nos bosques. E conduzindo a sua razão para cada uma das coisas boas e honestas (eos in unam quamque rem inducens utilem atque honestam), graças à razão e ao discurso (propter rationem et orationem) esse homem bom e sábio transformou em homens afáveis e brandos (mites, mansuetos) aqueles que antes só gritavam com insolência. Assim, o primeiro orador civilizou os seus semelhantes. Assim se estabeleceram as cidades, diz Cícero, assim nasceram a justiça e o direito. Graças à eloquência e à persuasão daqueles valores descobertos pela razão (ea quae ratione inuenisset), os homens aprenderam a cultivar a boa fé e a observar a justiça, habituaram-se a obedecer uns aos outros de 
livre vontade, e convenceram-se de que valia a pena trabalhar juntos e até dar a vida em favor do bem comum (I.3).

Naquela sociedade primitiva, os costumes fundados na natureza deram enfim lugar aos costumes da vida cívica, regida pela justiça e o direito. Ora, quem se deixaria resignar, sem resistências, ao direito, se da sua própria força lhe vinha muito mais poder? Quem aceitaria ser igualado junto daqueles de quem poderia entre todos distinguir-se? Quem abdicaria espontaneamente dos seus costumes, a não ser movido por um grave discurso, pergunta Cícero? Assim apareceu e se desenvolveu, a eloquência, para se ocupar das grandes causas da paz e da guerra, da justiça e do direito, e de outras causas importantes para o homem.

Mas Cícero não ignorava que a eloquência também podia tornar-se um mal (I.4). Quando alguma conveniência, imitadora perversa da virtude, alcançou sem razão o tesouro do officium dicendi, nasceu então a malícia que, apoiada no engenho, aprendeu também a corromper os indivíduos e a perverter as cidades.

Naquele tempo mítico, os homens ignorantes e sem fala náo costumavam ocupar-se de assuntos do estado, tal como homens grandes e eloquentes se náo ocupavam das causas privadas. As causas mais importantes eram entregues a homens ilustres e as pequenas controvérsias, a homens menos hábeis. Foi então que, homens eloquentes mas incultos começaram a mentir nos seus discursos e os seus superiores eram obrigados a resistir-lhes, para defenderem a verdade. 
Aos olhos da multidão, porém, os homens mentirosos pareciam, muitas vezes, superiores aos honestos. Sem estudos condignos, aqueles homens temerários e audazes tornaram-se, então, eloquentes sem sabedoria, mas a multidão considerou-os dignos de dirigirem a república, o que deu origem às maiores calamidades. Foi essa, segundo Cícero, a razão do abandono do estudo da eloquência (o divórcio entre eloquência e sabedoria), com o maior detrimento para a res publica.

Protecção da república é, pois, a sabedoria dos eloquentes, cuja autoridade se apoia na suma virtude (I.5). É, portanto, tão necessário estudar a eloquência, quanto é verdade que ela pode ser pervertida pela malícia dos homens (nibilo minus eloquentiae studendum est).

Cícero apresenta então não só o exemplo de homens que abandonaram o tumulto da vida pública para se dedicarem ao studium quietum, mas também o exemplo de outros que colocaram a sua virtude, autoridade e eloquência ao serviço da república. Da eloquência vêm inúmeras vantagens para a república, se ao seu lado estiver aquela que tudo governa (moderatrix omnium rerum), a sabedoria. É deste modo que Cícero declara o seu convite explícito ao estudo da eloquência. $\mathrm{Na}$ verdade, se os homens estáo acima das bestas por terem a capacidade de falar, eleva-se acima dos próprios homens aquele que excede o seu semelhante na capacidade da eloquência.

Para Cícero, é claro que sabedoria e eloquência são inalienáveis e que esta pertence de pleno direito à ciência política e civil, como arte por excelência que 
deve acompanhar o homem político romano, em cada momento do seu cursus honorum. Não pode ser, pois, reduzida a uma arte da forma, da palavra ou do significante. Homo eloquens, homo politicus, pois da eloquência nascera a cidade.

Formuladas de diversos modos, as relaçôes entre a cultura e a actividade cívica estiveram sempre no centro do pensamento de Cícero, desde o discurso que pronunciou em defesa de Árquias, em que o orador defendia não só a glória do poeta mas também a utilidade da sua própria conduta, ao serviço da res publica e dos seus concidadãos. (Narducci: 2009).

Doravante, a retórica teria que superar o divórcio entre o sapere e o dicere, conciliar a res e os uerba, depondo a presumível supremacia da dialéctica e da filosofia, mas também a tendência para a sobrevalorizaçáo da elocutio.

Todavia, essa noção de sapientia como noção plena e global exprimir-se-ia com maior esplendor ainda no De Oratore, em que Cícero expóe uma visão global da cultura cuja unificação e integração reside na retórica. É então que a retórica alcança o seu triunfo total, ascendendo ao estatuto de arte das artes.

Seria necessário ultrapassar o espírito dialéctico do séc. XIII e o tecnicismo das artes rhetorices medievais para voltarmos a encontrar a afirmação teórica e prática do primado da retórica, bem como a aliança entre retórica e sabedoria, como lugar da integração dos saberes. A cultura do Renascimento inaugura efectivamente uma 
era de valorização explícita da retórica, da sua finalidade ética e da sua utilidade social.

2. Conhecido, editado, traduzido e comentado como nenhum outro autor clássico, Cícero esteve no centro das atençóes e do estudo de milhares de intelectuais, ao longo de diversas geraçóes (Pereira, 2005: 464-541). Múltiplas razóes nos permitiriam, pois, afirmar que os textos de Cícero acima comentados poderiam ser um manifesto teórico do século XVI.

Efectivamente, um dos fenómenos que caracteriza a retórica no Renascimento, além da recuperação de inúmeros textos clássicos, é a reintegração da res e dos uerba, numa atitude de fervor crescente pela retórica, que a obra de Lawrence Green e James Murphy (2006) torna inegável, ao catalogar, entre os anos 1460-1700, cerca de 4000 títulos de retórica (3842), de 1717 autores diferentes, em 12325 ediçóes, em 310 lugares diferentes, por 3340 impressores, desde a Finlândia até ao México.

A Europa viveu entáo um período durante o qual muitos milhóes de europeus possuíram um conhecimento aprofundado da retórica e fizeram dela um saber operacional. Reis, príncipes, conselheiros políticos, homens de estado e seus secretários; papas, prelados e simples eclesiásticos (regulares e seculares, católicos, protestantes ou calvinistas); professores, juristas e historiadores; filósofos, teólogos e matemáticos; poetas e dramaturgos, mas também físicos, matemáticos e astrónomos percorriam um curriculum escolar que tinha na retórica o coroar dos estudos literários, de 
acordo com aquilo a que poderíamos chamar a reforma escolar realizada pelos humanistas, educadores e fundadores de escolas.

Naverdade, embora aquelas mudanças curriculares tivessem também alcançado as Universidades, foi sobretudo com a importância crescente dos colégios que a retórica alcançou um prestígio mais visível, resultado da nova atitude humanística para com a cultura do passado.

A retórica agora ensinada era uma retórica renovada e integral. Pertença dos humanistas, a retórica era o coroar dos studia humanitatis, que incluíam também a gramática, a poesia, a história e a filosofia moral. As actividades de retórica incluíam o estudo da literatura antiga que, muitas vezes, consistia em ler, traduzir, interpretar e comentar textos clássicos gregos e latinos. A filosofia, nomeadamente a filosofia moral, era pois legitimamente reclamada como parte da actividade dos humanistas, que se propunham mesmo restaurar o ideal de Cícero e combinar a eloquência com a sabedoria, isto é, a retórica com a filosofia.

Abundante é a produção literária deixada pelos humanistas, nomeadamente cartas e discursos, sem que, ao contrário da retórica da Antiguidade, estes sejam necessariamente políticos. Não sendo predominantes os discursos de carácter político, na vida social renascentista eram inúmeras as ocasióes para proferir discursos: discursos fúnebres e nupciais, oraçôes académicas (no início e no fim do ano académico, no início de um debate público ou no momento de alcançar um grau 
académico), discursos de embaixadores e diplomatas, discursos de obediência a papas, reis e príncipes, discursos de recepção a magistrados ou outras personalidades que visitavam a cidade, ou ainda discursos para pronunciar diante de uma assembleia de religiosos. Mas podíamos citar ainda uma abundante literatura poética e epistolar (pública e particular), que hoje constitui uma fonte importante de informação biográfica, histórica, cultural e intelectual, bem como outras obras, de historiografia e de filosofia moral, e ainda diálogos em prosa, sobre filosofia moral, ou sobre política, religião e educação. Estas obras, tão ecléticas como as de Cícero, seu mestre, eram lidas não apenas pelo seu conteúdo mas pela sua elegância formal e hoje em dia só podem ser inteiramente entendidas por referência às fontes clássicas, que os respectivos autores elegiam conscientemente.

Os manuais de retórica, por sua vez, procuram retomar e organizar toda a tradiçáo clássica, numa atitude cada vez mais globalizante, de quem encara a retórica não já como uma técnica especializada e formalista, mas como uma unidade. Sem prejuízo do primado de Cícero, a tratadística retórica renascentista é essencialmente eclética. Os textos renascentistas de retórica ensinam não só Cícero, mas também Aristóteles, Quintiliano, Hermógenes. Aliás, o estudo da retórica implicava agora, como acima disse, o estudo crítico da literatura, da história e do pensamento romano, o conhecimento dos autores pagáos, gregos e romanos, na sua língua original. Com graus diferentes de abertura aos textos clássicos pagãos, Erasmo e John Colet, J. 
Luís Vives e João Sturm são alguns nomes de grandes educadores e fundadores de escolas que, também fora da Itália, operaram uma verdadeira reforma escolar humanística, à qual deu continuidade, sobretudo na Europa católica, a Companhia de Jesus, com a sua vasta rede internacional de colégios.

Assim nasceram novas escolas que se foram tornando modelos de muitas outras e cuja finalidade principal era dotar os alunos da maior fluência verbal, no latim falado e escrito.

A retórica alcança então um prestígio jamais alcançado. Os humanistas de quinhentos restauram fielmente o primado que o De Oratore de Cícero reconhecia à arte da palavra, considerada na totalidade das suas diversas partes. ${ }^{1}$

Vale a pena recordar, no entanto, que este desejo de recuperar a dignidade de uma língua elegante e literária não era movido por superficiais razóes de estética, mas antes por razóes superiores de clareza, compreensão e eficácia. Essa é, sem dúvida, outra característica distintiva da descoberta da retórica no Renascimento: a descoberta simultânea da sua importância social, do seu papel fundamental na vida activa, do seu carácter prático. A retórica existe em função dos vínculos do

${ }^{1}$ Nem toda a tratadística renascentista, porém, é efectivamente adversa da dialéctica, e defensora do primado da retórica. Haja em vista a influência de autores como Rodolfo Agrícola (De Inuentione Dialectica) 1443-85, e Petrus Ramus (Aristotelicae Animaduersiones) 1515-72, junto de quem uma lógica 'reformada' como que conservava ainda os seus direitos, em prejuízo do Humanismo literário. 
indivíduo com a sociedade humana, tal como Cícero os descrevera no De Officiis (I.7.22).

A retórica do Renascimento afirma-se e desenvolve-se, pois, como um saber ao serviço do bem comum (da cidade, da pátria, da família, dos amigos). E essa ideia aplica-se tanto à oratória sacra como à oratória profana. Em tempos de Reforma e Contra-Reforma, quer o apóstolo (pregador), quer o homem político, aprendem a fazer da retórica o seu instrumento de combate, certos, como Cícero (Brut. 73.256-257; De Orat. I. 2. 7), da superioridade do orador sobre o general, no serviço pelo bem comum. É aliás um fenómeno característico do século XVI, mas cujas origens remontam ao século precedente. A partir da segunda metade do séc. XV, cresceu o número de religiosos com formação humanística, os quais naturalmente transpunham para a sua pregação os modelos da eloquência pagã e humanística. É nessa produção literária que encontramos, de modo mais evidente e duradoiro, os laços entre retórica e persuasão, que entre nós haveriam de ser solidamente exemplificados pela oratória do Padre António Vieira. Efectivamente, nos studia humanitatis da tradição escolar jesuítica, a oratória mereceu sempre um lugar de maior prestígio, em detrimento da poética, que a retórica não excluía mas como que mantinha em lugar secundário, ao serviço da maior eloquência (Ratio XVI.1).

Da utilitas da retórica e do seu carácter prático, resulta ainda outro aspecto distintivo da retórica no 
Renascimento: a sua finalidade ética. $\mathrm{Na}$ verdade, os teorizadores deste período, mais uma vez em reminiscência do pensamento de Cícero, tendem a justificar a retórica pela necessidade de tornar melhores os seus concidadáos. Para estes humanistas, que faziam da retórica o centro da sua própria obra, a eloquência era tão 'natural' como social. Defensores mais acesos da retórica chegavam a escrever sobre a futilidade do silêncio, como Enea Sílvio Piccolomini (Vickers, 1994:352) e a desaprovar formas de vida mais solitária, que achavam mais condicentes com um estilo de vida bárbara, inútil e estéril. Alguns humanistas denunciaram mesmo a vida monástica e contemplativa, não só por, a seus olhos, trair o ideal cristão de caritas, como ainda por negar radicalmente a natureza humana, a tal ponto consideravam a eloquência uma qualidade intrínseca da humanidade. Para esses, o homem solitário era pouco mais que besta. Stefano Guazzo, autor de La Civil Conversazione (Brescia, 1574), obra que conheceu um enorme êxito, e Alexandre Piccolomini (1508-1579), filósofo e retórico, apresentavam o homem como animal civil e comunicativo. Aquele que se excluísse das relaçóes humanas e se refugiasse nos montes e nos bosques, em breve acabaria por se tornar mais besta do que homem.

Em contrapartida, a todos era evidente o êxito da retórica na vida activa. $\mathrm{Na}$ cultura inaugurada pelo Renascimento, tal como o fundador mítico da cidade descrito no De Inuentione, assim o novo herói era justamente o orador capaz de elevar os seus concidadãos, o orador cujas palavras ou discursos podiam ser "mais 
preciosos (...) que mil cavaleiros do exército", escreveu Giangaleazzo Visconti (Vickers, 1994: 354). Aliás, o modelo de herói incontestado era agora Cícero. Por todos considerado herói do humanismo cívico, Cícero unia a eloquência e sabedoria à própria acção política (como demonstrava a sua obra e a sua biografia) e isso fazia dele modelo a imitar pelas geraçóes de humanistas. ${ }^{2}$

A finalidade ética da eloquência concebida no Renascimento é sugestivamente descrita por Poliziano, quando afirma que a eloquência é o único meio de penetrar na mente dos homens, sem violência, e de os levar a perseguir fins universalmente válidos (Garin, 1973: 121). Mas Vickers (1994: 350-355) cita ainda muitos outros humanistas que deram testemunho da sua convicção no poder da palavra e sublinharam a utilidade prática da retórica, não num sentido utilitarista ou pragmático, mas no sentido de serviço maior ao bem comum, e portanto à vida pública - uma posição que ecoa, mais uma vez, a narrativa mítica ciceroniana das origens da vida cívica e da eloquência.

3. Donde deriva, porém, a eficácia da retórica, podemos perguntar-nos. Responde Vickers que, para quem lê os clássicos, a eficácia da retórica resulta simplesmente do poder que exerce sobre as paixóes. As paixôes foram objecto de estudo particular da parte de variadíssimos textos de retórica clássica, de Aristóteles

${ }^{2}$ A expressão 'humanismo cívico' descreve essencialmente o cidadão instruído que, nos princípios do séc. XV, era o ideal de repúblicas como Florença. 
(Ret. II), Cícero (De Orat., II, 44, 188-191), Quintiliano (VI, 2, 20-36). Mas a retórica renascentista conferiu-lhe uma importância acrescida, reforçando a convicção de que o veículo da persuasão é o affectus, isto é, a fonte dos afectos, as paixóes. Transpunha-se assim para o campo da retórica o novo relevo que, na psicologia, alcançara a ideia de vontade humana como fonte da liberdade e da responsabilidade 3 . Uma e outra razão conferiram então ao mouere da retórica renascentista uma valorização crescente. $\mathrm{O}$ mouere seria em breve elevado a função primeira da retórica: dirigir a vontade dos homens para fins nobres. E o que era válido para a oratória era-o também para a poética. Lida e analisada a poesia segundo os processos retóricos da inuentio, da dispositio e da elocutio, disso resultava que a maior glória do poeta era justamente a capacidade de suscitar as paixóes.

Assim, ao procurarmos sintetizar os aspectos essenciais da retórica no renascimento, não podemos deixar de salientar as mudanças operadas entre a segunda metade do séc. XVI e a segunda metade do séc. XVII. Na verdade, o relevo crescente do papel das paixôes na persuasão levou ao estabelecimento de uma

3 Vickers (1994: 355 ss) cita diversos autores humanistas (Petrarca, Salutati, Alberti, Vives) que representam, para nós, a expressão da nova psicologia voluntarista, que então se afirmava, e que explicava, em parte, a crença na educação para modelar a personalidade humana e desenvolver a autodeterminação. Para Salutati, por exemplo, era fundamental o primado da vontade sobre a inteligência, pois é o acto livre da vontade que torna o homem livre. "Objecto da vontade é o bem; objecto da inteligência é a verdade. No entanto, é preferível desejar o bem a conhecer a verdade" escrevera também Petrarca. 
nova hierarquia de valores no seio da retórica. Entre os três fins primordiais (docere, mouere, delectare), o mouere ganhou a primazia. Por outro lado, entre as cinco partes da retórica (inuentio, dispositio, elocutio, memoria e actio) o interesse pela elocutio começou a ganhar a maior das atençôes. Assim se teria desvanecido o equilíbrio ideal entre as diversas partes constitutivas da retórica.

Uma e outra mudança, porém, estavam intimamente ligadas entre si, já que era em busca da maior persuasão que a elocutio desenvolvia novos e mais abundantes recursos expressivos, ascendendo, por fim, ao estatuto superior. Para muitos humanistas, como aliás para Quintiliano (VIII, 15-16), a elocutio era a parte mais difícil da retórica e no entanto a mais importante, sem a qual a oratória seria semelhante a uma "espada embainhada", isto é, uma espada sem eficácia combativa.

Além disso, a supremacia do mouere verificava-se tanto na oratória sacra como na profana. Seà luz dos dados históricos, o fenómeno da maior relevância da elocutio e do mouere é visto como uma 'perda', tal fenómeno deve antes ser entendido como o resultado da adaptação da disciplina às novas exigências e necessidades, ou seja, como resultado da anterior concepçáo da utilidade social da retórica, que distingue precisamente retórica renascentista da clássica e medieval.

A supremacia da elocutio fez com que, segundo Vickers (1994: 361), os elencos de figuras retóricas desta época pudessem ir de 200 a 5000. Era segundo essa forma mentis que os humanistas pensavam a retórica. 
Para quem aprendia ou ensinava, no entanto, a retórica não era simples ornamento fútil e superficial; era, pelo contrário, a expressão perfeita das próprias ideias - por parte de quem acreditava vivamente no poder eficaz da palavra, se usada de acordo com regras. Mais do que elaboração formal, a retórica era a comunicação perfeita - por parte de quem acreditava na natureza social do homem, na centralidade da linguagem para as relaçóes sociais e na capacidade do orador para influenciar as pessoas, graças à sua dedicação à verdade e à virtude. $\mathrm{O}$ primado da elocutio era assim o reflexo de uma visão da elocutio ao serviço dos mais nobres ideais humanos; e o primado das figuras, o melhor modo de realizar a elocutio. Mover os afectos e a vontade por meio da linguagem (persuadir) tornou-se propriedade fundamental de toda a literatura.

Naturalmente, a esse fenómeno não ficaram alheios os actores principais da Reforma. Na Europa protestante, os exercícios de retórica faziam parte dos principais deveres dos pregadores (no séc. XVI, na Alemanha, tais exercícios constituíam mesmo um dos requisitos fundamentais de preparação para o sacerdócio). Na Europa da Reforma Católica, por seu lado, o ensino da Companhia de Jesus, uma ordem de padres humanistas, fez também da retórica elemento fundamental da formação, não só do pregador como também do cidadáo comum - chamado a ser homem de bem, consciente dos seus deveres sociais. Também neste caso, o ideal ciceroniano do orador sábio e virtuoso se espelhava no ideal educativo da Companhia, 
concretizado agora no binómio inseparável de 'letras e virtude'. E durante cerca de dois séculos, dos numerosos colégios da Companhia de Jesus saíram geraçóes de homens (filósofos, pregadores, missionários, teólogos, magistrados, médicos, juristas, políticos, altas dignidades eclesiásticas e civis, e ainda artistas, músicos, historiógrafos, físicos, matemáticos, astrónomos e todo o género de cientistas) senhores exímios da palavra, conhecedores da melhor doutrina retórica e dos seus modelos clássicos, preparados para usar a linguagem segundo as regras da eficácia. Esse domínio da palavra verificou-se não apenas no campo da linguagem literária e filosófica, mas também no campo do discurso científico ${ }^{4}$, ao qual a influência da retórica também se havia estendido, comprovando mais uma vez a sua utilidade prática na vida social.

Não há dúvida de que o Humanismo influenciou profundamente os princípios adoptados pela tradição escolar jesuítica, desde o primeiro colégio fundado em Messina em 1548. A retórica, disciplina central cultivada pelo movimento, era, por definição a arte da persuasão. Envolvia não apenas o intelecto mas também a imaginação e as emoçôes. Por isso, a Companhia de Jesus não the podia ficar alheia, nem presa nas malhas seculares da dialéctica, peça central no sistema escolástico tradicional. Para isso, o orador/pregador formado

${ }^{4}$ Vickers (1994: 370 e 1983) recorda o exemplo de Galileu, que se serviu da retórica epidíctica para defender o seu sistema do mundo e refutar as doutrinas aristotélicas. $\mathrm{Na}$ Universidade de Tubingen, por exemplo, os manuais de retórica de Melanchton constituíam os livros de estudo do primeiro ano de astronomia. 
pelos jesuítas dispunha de dois tesouros simultâneos, o tesouro da eloquência sagrada e ao mesmo tempo o conhecimento erudito e crítico sobre o humanismo profano, dois instrumentos com os quais pretendia renovar a piedade e os costumes.

Os Jesuítas perceberam, tal como os primeiros humanistas, que o novo estilo, que a retórica ajudava a cultivar, persuadia! $\mathrm{O}$ bom estilo literário (vs estilo bárbaro) permitia ir mais além do assentimento intelectual da parte do público e transferir a verdade para um modo pessoal e assimilado de sentir, pensar e agir. Embora possamos pensar que uma mudança no estilo não seria mais do que uma mudança superficial, ela correspondia, na verdade, a uma mudança operada no modo de apreender e de conceptualizar a realidade e, portanto, a uma nova forma mentis.

Para os colégios, o cânone dos autores clássicos, tal como a Ratio Studiorum veio mais tarde a estabelecer, ao fim de cerca de meio século de experiência escolar, era justificado com o argumento tradicional de que os clássicos constituíam os 'despojos do Egipto' (Constituiçôes [359.1]; Fumaroli 1994: 286). Mas a principal razão para esta relação intrínseca entre os clássicos e o cristianismo no curriculum escolar jesuítico era, além do seu conteúdo ético, a convicção clara da necessidade de cultivar um estilo agradável e persuasivo para o exercício do ministério da Palavra, que a Companhia assumira de modo particular no ensino e na pregação, junto de uma Europa mergulhada na maior controvérsia religiosa de sempre. 


\section{Bibliografia}

Código Pedagógico dos Jesuitas. Ratio Studiorum da Companhia de Jesus - Regime escolar e Curriculum de estudos. Edição bilingue latim-português. Introdução e versão portuguesa de Margarida Miranda. Lisboa, Esfera do Caos, 2009 (= Ratio).

Constitutiones Societatis Iesu a Congregatione Generali XXXIV annotatae et Normae Complementariae ab eadem Congregatione approbatae. Roma, 1995. Edição Portuguesa: Constituiçôes da Companhia de Jesus. Braga: Livraria A. I., 1997 (= Const.)

Fumaroli, Marc (1994), L'Âge de l'éloquence. Rhétorique et "res literaria» de la Renaissance au seuil de l'époque classique. Paris : Albin Michel.

Garin, E. (1973), "Discussioni sulla retorica” in E. Garin, Medioevo e Rinascimento, Bari: Laterza.

Green, Lawrence D., Murphy, James (2006), Renaissance Rhetoric. A Short-Title Catalogue 1460-1700, Ashgate: New York.

Kristeller, Paul Oskar (1982), El pensamiento renacentista y sus fuentes. México: Fondo de Cultura Económica.

Narducci, Emanuele (2009), Cicerone. La parola e la politica. Bari: Laterza.

O'Malley, John W. (1993), The first Jesuits. Harvard University Press, Cambridge. 
Pereira, Belmiro Fernandes (2005), Retórica $e$ eloquência em Portugal na época do Renascimento. Coimbra: Faculdade de Letras.

Vickers, B. (1983), "Epideictic Rhetoric in Galileo's "Dialogo"”, Annali dell'istituto e Museo di Storia della Scienza di Firenze, 8: 69-102.

Vickers, Brian (1994), Storia della Retórica, Bologna: Il Mulino. 


\title{
A História OpVs Oratorivm e "EsPERTADOR DO ENTENDIMENTO"
}

\author{
Nair de Nazaré Castro Soares
}


A preocupação prioritária da história é estudar o homem, os seus desafios, contestaçóes, convergências, resolver a dialéctica vertical específica de cada época, apesar dos elementos epistemológicos que se interpenetram e se dimensionam em variadíssimas interpretaçôes ${ }^{1}$.

Reflectir sobre o papel e o significado da história no humanismo renascentista, período em que a dignitas hominis constitui um vector central do pensamento, é clarificar as raízes do próprio movimento humanista. Walter Ullmann atribui mesmo ao interesse pela história antiga, pela vida das grandes figuras, o desabrochar do humanismo ${ }^{2}$. Os feitos ilustres dos homens do passado, as suas instituiçóes, o seu direito, os seus valores, a sua língua, na riqueza e pureza originais, vão ser objecto de reflexão nova.

O despertar da curiosidade histórica, que envolve não só a valorização da biografia das grandes personalidades do passado, mas o diálogo que o presente com elas estabelece, exprime-se tanto nas consideraçóes tecidas nos prefácios a traduçôes de obras dos historiadores da Antiguidade, como em obras históricas originais. Manifesta-se nas reflexóes sobre a utilidade da história, que abundam na epistolografia humanista e nos tratados

${ }^{1}$ Mattoso 1988.

${ }^{2}$ Ullmann 1977: 219. 
de retórica da época; em obras que se debruçam, por inspiração de Aristóteles, sobre a natureza da história, na sua relação com a poesia, como é o caso do diálogo retórico, Actius, sobre a arte e o estilo em prosa e em verso, do humanista da corte aragonesa de Nápoles, Giovanni Pontano; em tratados que se pronunciam, à semelhança do opúsculo de Luciano de Samósata, De conscribenda historia, sobre a arte de escrever história.

Papel decisivo nesta abertura franca para um mundo novo - o mundo da história e da cultura clássica ${ }^{3}$ - têm as traduçóes elaboradas a partir dos originais gregos e latinos, no Quattrocento italiano. Muitas delas, que se empreenderam sob a égide do Papa Nicolau V, o fundador da Biblioteca Vaticana, estão na base de muitas outras que se fizeram em língua vulgar.

Todo um conhecimento de prosadores, em que têm papel de relevo historiadores como Heródoto, Tucídides, Xenofonte, Demóstenes, Políbio e autores de biografias e de tratados que sintetizam o pensamento filosofico da época helenística, como Diógenes Laércio e Plutarco, era comum entre os homens cultos do Renascimento, quer soubessem lê-los no original grego, ou apenas nas traduçóes latinas ${ }^{4}$.

A divulgação de obras de literatura latina, dos tratados morais e de retórica de Cícero, das tragédias e tratados de filosofia moral de Séneca, das histórias de

${ }^{3}$ Conhecida é a predilecção de Petrarca pela história, que o levou a procurar zelozamente manuscritos de Tito Lívio e Plínio, sobretudo, vide Nolhac 1965: vol. II, cap. VI "Pétrarque et les historiens romains".

${ }^{4}$ Vide Kristeller 1979: 21-22; Burke 1992: 171-193. 
César, Tito Lívio, Valério Máximo, Suetónio, Tácito, para falar apenas nos prosadores mais representativos, editados com frequência, no original e em vulgar, contribui também para que o latim se torne o veículo universal da cultura da época e esteja na base da grande familiaridade, mantida com as obras da Roma antiga.

Assim, uma das características fundamentais da literatura renascentista, que a diferencia da produçáo medieval, àparte a diferente riqueza formal da língua latina, é o aproveitamento que entáo se faz da literatura clássica, sobretudo da literatura grega.

Petrarca, no seu afã pela busca de originais das obras dos autores clássicos, encontra na catedral de Verona as Cartas de Cícero a seu amigo Ático. Estas revelam a verdadeira dimensão do Arpinate como homem público, empenhado na vida activa e seus valores, que vão ganhar peso e equacionar-se, a partir de então, com os da vida contemplativa, que dominaram a Idade Média. É assim que Petrarca, considerado o primeiro humanista, se torna a demonstração emblemática do encontro e convívio com os autores antigos, que se impôs no nascente humanismo italiano e europeu 5 .

As abordagens que Cícero faz à história, ao longo de vários dos seus tratados, que vão desde o seu valor $\mathrm{e}$

5 Petrarca endereçou cartas não só a Cícero como ainda a outros escritores da Antiguidade, como Homero, Tito Lívio, Horácio, Virgílio e Séneca. Vide Petrarca, Francesco (1964), Opera di Francesco Petrarca, a cura di E. Bigi. Milano: 880 e sqq. Sobre a discussão da figura histórica de Cícero, pensador e cidadão romano, que envolveu Petrarca e Coluccio Salutati, a quem se deve a descoberta das Epistulae familiares, e ainda Pier Paolo Vergerio, vide Baron 1966: 121-129. 
utilidade à arte de a escrever - a denunciar a predilecção do "pai do humanismo" por este ramo do saber -, não passaram despercebidas aos autores do Renascimento, que seguiram o Arpinate como modelo da arte da palavra, de estatura moral e empenhamento cívico.

A expressão do De oratore (2. 9), que se refere à história como 'testemunha dos tempos, luz da verdade, vida da memória, mestra da vida, mensageira da antiguidade', Historia uero testis temporum, lux ueritatis, uita memoriae, magistra uitae, nuntia uetustatis, torna-se como que uma divisa do pensamento humanista ${ }^{6}$. Mas em vários outros passos da sua obra, Cícero explicita o valor da história dentro destes parâmetros: o conhecimento da história é necessário ao orador e ao homem de estado (De legibus, 3. 41; De oratore, 1.18; $1.159 ; 1.201)$ e adequado ao aperfeiçoamento moral (Pro Archia, 14-15; Por Sestio, 48; De finibus, 5. 64).

Os autores do Renascimento, atentos ao pensamento e à expressão ciceronianos, atribuíram à história um papel análogo ao da filosofia moral. Cabe também a Petrarca, no seu tratado sobre os

${ }^{6} \mathrm{O}$ passo do De oratore (2. 9) de Cícero é transcrito, e. g., na o ração latina Em louvor de todas as artes e ciência de Pedro Fernandes, quando se pronuncia sobre a história. Em língua portuguesa, surge da pena de Fr. Heitor Pinto (1941), Imagem da Vida Cristã, M. Alves Correia ed., 4 vols., Lisboa (cap. XIX do Diálogo dos verdadeiros e falsos bens), vol. IV: 261: «A história, como diz Marco Túlio no segundo De oratore é testemunho dos tempos, luz da verdade, vida da memória, mestra da vida, messegeira da antiguidade. Todo o homem que quiser saber cousas notáveis, e açacadar o engenho, e limar o juízo, e refinar o entendimento, e saber grandes avisos e adquirir muita prudência, para se governar a si e aos outros, seja lido nas histórias». Vide Narducci 2009; López Eire 2008: 1-32. 
homens ilustres, De uiris illustribus, dar o tom à leitura paradigmática e pedagógica da história, que o humanismo consagra. Sem demora, esta lição do humanismo italiano iria ser seguida pelo mundo culto e perdurar por mais de um século.

De todos os géneros literários cultivados pelos antigos, a história é talvez o que mais seduz os tradutores renascentistas. A glória de Roma era incansavelmente entoada pelos humanistas italianos, preocupados em ajustar a beleza do seu discurso à grandiosidade dos feitos dos seus antepassados, como o testemunha Lorenzo Valla, no prefácio ao primeiro livro das suas Elegantiae Latinae, que inspiraram as consideraçóes de gramáticos humanistas, como o espanhol Antonio de Nebrija e o português Fernando de Oliveira, sobre a língua, companheira do império ${ }^{7}$. Esta glorificação do passado mítico-histórico de Roma desencadeia uma verdadeira emulação, não só entre os escritores italianos, herdeiros directos do grande império - não poderemos esquecer o espírito da Monarquia de Dante e mesmo de Il principe de Maquiavel - mas ainda entre os humanistas europeus, que se orgulham das suas origens e que cantam a bravura dos seus heróis nacionais e a grandeza das suas pátrias ${ }^{8}$.

${ }^{7}$ Vide, sobre este assunto, Asensio1974: 1-16.

${ }^{8} \mathrm{O}$ orgulho das origens da nação portuguesa manifesta-se entre nós, no séc. XVI, em obras como o De antiquitatibus Lusitaniae de André de Resende, que pretende provar, pelo recurso à ciência filológica, a dignitas da nação portuguesa, abundante em testemunhos da presença dos romanos, e ainda na própria literatura cavaleiresca, ou antes, na sua reactualização paradigmática, como é o caso da Crónica do Imperador Clarimundo de João de Barros. 
A renovação dos horizontes ideológicos, no que se refere ao reequacionamento da concepção do poder e do estado, nos finais do séc. XIV na Europa, vai favorecer a recepção dos modelos antigos e mesmo condicionar a orientação para a tratadística moral e histórica de incidência política. Os romances de cavalaria, os ciclos épicos tinham contribuído para o conhecimento e divulgação do passado mítico-histórico greco-romanos. É sobretudo em França, berço da tradição novelística, e na corte de Borgonha que este tipo de literatura conhece um rápido florescimento, por influência do humanismo italiano?.

Portugal não foi estranho a estas influências da Europa culta, dado o intercâmbio que com ela desde cedo estabeleceu. Quando o movimento humanista se iniciou em Itália ali se encontrava um escol português de eclesiásticos, ocupados na cúria, ou de estudantes que cursavam as universidades de Siena, Pádua, Pavia e Bolonha, famosas pelo estudo de direito.

Apesar de já as cortes de 1473 se terem manifestado contra a manutenção de escolares, a migração não parou desde o tempo de D. João $\mathrm{I}^{10}$. A sociedade portuguesa, estruturada até entáo segundo o modelo da hierarquia

${ }^{9}$ Um interesse generalizado pela Antiguidade é alimentado por toda uma corrente de obras histórico-romanescas, em prosa, como as diferentes versôes do Romance de Alexandre, do Romance de Eneias, do Romance de Tróia, do Romance de Tebas, da História do Tosão de Ouro, das Histórias de Hercules, ou em verso, como é o caso do poema Trois grands, que canta Alexandre, Pompeu e Carlos Magno. Vide Faral . 1967.

${ }^{10} \mathrm{O}$ jurista João das Regras, formado em Bolonha, é exemplo paradigmático. 
eclesiástica, inicia uma renouatio, nos vários domínios da cultura, que pretendia garantir a consolidação da consciência nacional, de acordo com as solicitaçóes do mundo civilizado de então. A partir da dinastia de Avis, vários factores propiciaram a abertura ao mundo moderno. Entre eles, as relaçôes com a corte de D. João II de Castela, em ligação, por afinidade familiar, com o reino de Nápoles de Afonso V, o Magnânimo paradigma do "principe umanizzato" do Renascimento.

A presença da cultura italiana, na corte de Borgonha da Duquesa Isabel, filha do nosso rei D. João I - casada com Filipe o Bom, duque da Borgonha e conde da Flandres - que mantinha estreitas relaçóes com a corte portuguesa e conservava ao seu serviço portugueses cultos, vindos no seu séquito ${ }^{11}$. Esta corte, a mais brilhante e faustosa da Europa, contava com uma das bibliotecas mais famosas do tempo e acolhia uma verdadeira escola de artistas de iluminuras, de que é testemunho o Livro de Horas do rei D. Duarte.

Ao labor do português Vasco de Lucena se deve a tradução francesa da Ciropedia -, a partir da versão latina de Poggio -, a Histoire d'Alexandre, traduzida de Quinto Cúrcio e completada, nas lacunas do original, sobretudo pela Vida de Alexandre de Plutarco, segundo a versão latina de Guarino de Verona. Muito provavelmente é ele também o autor da Vida e feitos de Júlio César, tradução

${ }^{11}$ Entre as figuras do séquito de D. Isabel de Portugal, está Afonso de Lucena, médico da princesa. O filho, Vasco de Lucena, pôde estudar nas universidades de Colónia e Paris e foi chamado a colaborar na educação do príncipe, o futuro Carlos o Temerário. 
portuguesa de Li fet des Romains, oferecida antes de 1466 pela duquesa Isabel a seu sobrinho, o Condestável D. Pedro, pretendente ao trono de Aragão ${ }^{12}$. Esta obra é uma exposição coerente da história de César, colhida em várias fontes, entre as quais se contam autores clássicos, tais como Suetónio, Salústio, Júlio César, Lucano $^{13}$. Não sem razão se legitima o conhecido gosto do príncipe herdeiro desta corte, Carlos o Temerário, pelas obras históricas.

Mas é sobretudo o contacto directo de D. Pedro, o Infante das Sete Partidas, com a cultura europeia, e designadamente com o humanismo italiano, que permitiu o desabrochar dos ideais humanistas, em Portugal. Nas suas viagens pela Europa (1424-1428) - Inglaterra, Flandres, Hungria, Itália (Veneza, Pádua, Florença e Roma) - o Infante D. Pedro relaciona-se com humanistas italianos, como Pier Paolo Vergerio (1370-1444), que conheceu na corte de Segismundo da Hungria, autor de uma obra 'Sobre os nobres costumes e os estudos liberais da juventude', o De ingenuis moribus et liberalibus studiis adolescentiae (1402), o primeiro tratado pedagógico, na verdadeira acepção da palavra, quer pelo teor prático da sua doutrina, quer pela real divulgação que conheceu em toda a Europa. A partir deste tratado de Vergerio, impunham-se como cartilha a obra de Cícero, que, no seu sincretismo, fazia a síntese

12 É esta a opiniāo de Mateus, M. Helena (1971), Vida e feitos de Júlio César, ed. crítica da tradução portuguesa quatrocentista de Le fet des Romains. Lisboa.

${ }^{13}$ Vide Monfrin 1972: 152-154. 
do pensamento retórico e filosófico da Antiguidade grega, a Institutio oratoria de Quintiliano e o De liberis educandis de Plutarco, obras que se tornaram verdadeiro Vademecum da pedagogia humanista, em moldes modernos.

Traduz a obra de Vergério, a pedido do Infante D. Pedro, Vasco Fernandes de Lucena, o infatigável humanista ao serviço dos ideais pedagógicos e cívicos dos príncipes de Avis, que verte "em lingoajem" os tratados de Cícero e o Panegírico de Trajano de Plínio-oMoço, que difundem o ideal do orador e de estadista ${ }^{14}$.

Ao rei D. Duarte dedica Alonso de Cartagena, futuro Bispo de Burgos, um Memoriale uirtutum, baseado na Ética de Aristóteles e a tradução do primeiro livro do De inuentione do Arpinate, indício seguro dos gostos e ideais retóricos da corte portuguesa ${ }^{15}$.

Indício seguro das preocupaçôes de um país de aspiração ultramarina, apostado em acertar o passo com os grandes centros culturais europeus, é o afã de tradutores de obras clássicas, especialmente Cícero ao Infante D. Pedro se deve a primeira tradução para

${ }^{14}$ A tradução de Vergerio de Vasco Fernandes de Lucena, hoje perdida, figurava ainda entre os livros da biblioteca de D. João $\mathrm{V}$ e conheceu a maior divulgaçáo nos séculos XV e XVI, a ajuizar pelas centenas de manuscritos e pelas mais de trinta ediçóes incunabulares.

${ }^{15}$ Entre 1421 e 1431, encontra-se em Portugal, em missão diplomática, Alonso de Cartagena, futuro Bispo de Burgos, tradutor de Cícero e Séneca. Sobre D. Alonso de Cartagena, considerado um dos primeiros representantes do primeiro humanismo castelhano, vide o estudo inserto, neste volume, de Tomás González Rolán, "Proyección política y pedagógica del Prólogo a la Rethórica de Cicerón dedicado por Alfonso de Cartagena al Infante D. Duarte”. 
português, o De offciciis, testamento moral do Arpinate - e também de Séneca, de tratados de arte militar, de panegíricos imperiais. Apesar de os príncipes de Avis protegerem a cultura literária e escreverem eles próprios obras de formação cavaleiresca ou de reflexão filosófica, de divulgarem os clássicos latinos, de promoverem a reestruturação das instituiçóes e de darem incremento à política da expansão oceânica, não se poder falar, nesta época, senão de proto-humanismo, mais ideológico do que filológico. $\mathrm{O}$ que não impede de se reconhecer o notável contributo que deram ao humanismo filológico, que alvorecia, e à Língua Portuguesa, o Infante D. Pedro, o Rei D. Duarte e o historiador ao serviço de ambos, Fernão Lopes.

A historiografia, a par das traduçôes da produção histórica da Antiguidade clássica, é um dos géneros que vai conhecer grande fortuna, nos alvores do Renascimento, ligada à exaltação das grandes casas e famílias principescas e seus actuais representantes. Exemplo expressivo é a corte de Afonso, o Magnânimo: ao reconhecer o importante papel da história, como disciplina de grande utilidade didáctica e sobretudo como verdadeiro manancial de exempla que fornece uma variedade de ensinamentos quer a nível pessoal quer político, acolhe humanistas famosos que escrevem a sua história e a divulgam na universal língua latina. Muitas são as obras históricas que glorificam a dinastia aragonesa de Nápoles: o De Dictis et factis Alphonsi regis e o Liber rerum gestarum Ferdinandi regis, ambos da autoria de Antonio Beccadelli, Panormita, o De rebus gestis ab Alphonso primo neapolitanorum rege de 
Bartolomeo Facio e o Compendio della storia del regno di Napoli de Pandolfo Collenucio ${ }^{16}$.

Afirma-se também entre nós, além do interesse pelos romances de cavalaria e pelos tratados de educação de príncipes, um vincado gosto pela produção historiográfica destinada a relatar as proezas cavaleirescas e os feitos heróicos dos grandes senhores, em que as acçóes de figuras individuais servem de paradigma e exemplo - e de obras históricas orientadas no sentido da apologia real ${ }^{17}$.

Fernão Lopes é mesmo o exemplo perfeito do historiador preocupado com a verdade dos factos, conciliada com o engrandecimento da dinastia de Avis e dos seus príncipes, ao serviço de quem póe o seu labor.

Náo é de estranhar que surja da sua pena, na Crónica del Rei dom João I da boa memória, a definição ciceroniana de história: «a estoria ha de seer luz da uerdade e testemunha dos antigos tempos», expressão que traduz a ciceroniana (De oratore 3. 9. 36), Historia testis temporum, lux ueritatis ${ }^{18}$.

${ }^{16}$ Vide Cochrane 1981: XVI e 3-159; Soares 2003: 9-32.

17 Lembro, de Fernão Lopes, as Crónicas de D. Pedro, D. Fernando e D. Joáo I; de Zurara, a Crónica da tomada de Ceuta e a Crónica dos feitos da Guiné, um verdadeiro panegírico da figura do Infante D. Henrique, caracterizado pelos seus dotes intelectuais e rodeado de sábios; de Rui de Pina, as Crónicas de D. Duarte, $D$. Afonso $V$ e $D$. João II. Destinadas a relatar as proezas cavaleirescas e os feitos heróicos dos grandes senhores são a Crónica do Condestabre, que o Mestre João Fernandes traduziu para latim, a Crónica do Infante D. Fernando, de Frei Joáo Álvares, e as Crónicas de D. Pedro de Meneses e de D. Duarte de Meneses, de Gomes Eanes de Zurara.

${ }^{18}$ Fernão Lopes (1968), Crónica del Rei dom João I. Lisboa: 83 (II parte, cap. 37). 
Sem pretender considerar Fernão Lopes um historiador humanista, enquadrado que está ainda na mundividência medieval, manifestam-se já na sua prosa narrativa, na sua arte de escrever, certas particularidades que anunciam uma fina sensibilidade para certos motivos e valores, que vão informar o discurso humanista. A técnica narrativa, em que o gosto do pormenor fornece uma pintura fiel da realidade da época e dos seus heróis, caracterizados em acção, tem as suas raízes últimas em Tucídides, muito embora Fernão Lopes a tenha colhido muito provavelmente na literatura novelística, que privilegiava a vivacidade e intensidade dramáticas e valorizava o discurso oral ${ }^{19}$. Este processo narrativo, que faculta a observação das atitudes e comportamentos das personagen $s^{20}$, permite transmitir umalição implícita nos próprios acontecimentos, uma das funçôes primordiais da história antiga no humanismo renascentista.

A preocupação formal, que caracteriza os autores do Renascimento, já se prenuncia em Fernão Lopes, a ajuizarmos pelo prólogo que abre a Crónica del Rei dom João $I$, onde previne os seus leitores que não busquem «fremosura e novidade de pallavras» pois «nos», afirmava, «leixados os compostos e afeitados rrazoamentos, que muito deleitom aquelles que ouvem, amtepoemos a simprez verdade, que a afremosemtada falssidade ${ }^{21}$.

${ }^{19}$ Atkinson 1962: 3-24.

${ }^{20}$ Quando o autor dá a palavra às personagens do mundo por ele narrativizado, adopta a forma "mais mimética" do discurso, no dizer de Genette 1979: 170.

${ }^{21}$ Fernão Lopes (1977), Crónica del Rei dom João I. Lisboa: 2 (I parte). 
Própria da mentalidade humanista, e dentro de postulados que pertencem à tradição clássica, é a definição de história em termos estéticos, a valorização da forma e do estilo na arte de narrar, indissociável da preocupação da verdade, que não deve, contudo, sobrepôr-se à exemplaridade dos feitos, seu principal objectivo.

De facto, uma nítida evolução se vai fazer sentir na arte de escrever história ${ }^{22}$, condicionada sobretudo pelas novas exigências impostas pela realidade portuguesa e pela progressiva assimilação dos modelos clássicos. Manifestam-se então, entre os humanistas, preocupaçôes literárias, no que respeita à obra histórica, definida por Cícero como opus oratorium (De legibus 1. $5)^{23}$.

João de Barros, no prólogo da sua Década III, pronuncia-se sobre a importância da forma e do estilo na arte de narrar, nestes termos: «tem tanto poder a força da eloquência, que mais doce, e acepta he na orelha, e no animo huma fabula composta com decoro, que lhe convem, que huma verdade sem ordem, e sem ornato, que he a forma natural della» ${ }^{24}$.

Mas é a Damião de Góis, no "Prólogo" da sua Chronica do Prinçipe Dom Joam, que se deve a definição humanista do estilo histórico:

${ }^{22}$ Vide Macedo 1982: 55-243.

${ }^{23}$ Sobre o estilo requerido para a história, vide as considerações feitas por Cícero em Orator, 42; 66; 124.

${ }^{24}$ Vide João de Barros (1973), Décadas da Ásia, edição anastática da de Lisboa (1777) Na Regia Officina Typografica: prólogo, sem numeração de páginas. 
«\& muito mais se tratta de feitos de Reis, \& grandes senhores, porque nestes se requere alto stylo descrever, grãde ornamento de lingoagem, sotil \& discreto artifiçio rhetorico» É que, prossegue: «ha história tem em si tâta magestade, que nella se nam pode sofrer palaura nenhua que no lugar em que se póe nam traga consigo grauidade, honestidade \& autoridade, às quaes leis $\&$ jugo a que ho stylo histórico está sugeito, $\&$ de que cố razam nam pode sair» ${ }^{25}$.

Além da definição de história em termos estéticos, uma outra componente se afirma. A concepção valorativa e paradigmática da história, sintetizada de forma eloquente no táo glosado passo do De oratore (2. 9) ciceroniano e abordada no prefácio de $A b$ urbe condita de Tito Lívio ${ }^{26}$, caminha de par com a preocupação da verdade, desde os primórdios da historiografia portuguesa.

A concepção da história como escola de virtudes, presente já na Crónica do Condestabre, em Fernão Lopes,

${ }^{25}$ Damiam de Goes (1905), Chronica do Prinçipe Dom Ioam por Damiam de Goes. Coimbra: 1. Tece também considerações desta natureza, em Damião de Góis (1944 e 1954), Crónica do Felicíssimo rei D. Manuel 2 vols. Coimbra: 105 (vol. II, Parte IV, cap. 38). Pronuncia-se ainda este humanista sobre a arte de escrever história e o "ofício" do historiador, na Vrbis Olisiponis descriptio Raúl Machado ed. (1937). Lisboa: 15-16: para que a história seja "imparcial e completa", quem se dedique a escrevê-la necessita de estar liberto de outras ocupaçóes, para ter paz de espírito, e necessita ainda do favor e auxílio dos Príncipes, que premeiem o seu trabalho e a sua arte.

${ }^{26}$ Neste prefácio, Tito Lívio apresenta a sua história, $A b$ urbe condita, como uma obra concebida com arte literária, com um alcance moral e nacional. 
em Azurara e Rui de Pina $^{27}$ tem o seu representante máximo, no humanismo renascentista, na historiografia de João de Barros ${ }^{28}$. É sobretudo no prólogo da Década III que o historiador moralista, para quem «a Historia he hum espertador do entendimento", revela os seus propósitos e métodos.

Serve-se dos autores clássicos e dos modernos, tais como Paulo Jóvio e António de Nebrija, para explicitar o seu conceito de história e a arte de a escrever. A preocupação da verdade náo deve sobrepôrse à exemplaridade dos feitos, seu principal objectivo. Náo quer isto dizer que a obra de João de Barros falseie a verdade, ou que nela não se formulem críticas, mas apenas que a sua atitude epistemológica na seriação e apresentação dos factos é tipicamente humanista, com

${ }^{27}$ Vide Chronica do Condestable de Portugal Dom Nuno de Álvares Pereira, Remédios ed. (1911): 1; Lopes, Fernão (1977 e 1968), Crónica del Rei dom Joáo I da boa memória, I parte (1977), cap. 164: 309 e II parte (1968), cap. 98: 211-212; Gomes Eanes de Zurara (1915), Crónica da Tomada de Ceuta, Esteves Pereira ed. Coimbra, cap. 38: 117; Fr. João Álvares (1960) Trautado da vida e feitos do muito venturoso S. or Infante D. Fernando, Adelino de Almeida Calado. ed. Coimbra.: 4; Rui de Pina (1977), Chronica do Senhor Rey D. Duarte, cap. XV, in Crónicas, M. Lopes de Almeida ed.: 522 .

${ }^{28}$ Estas sáo palavras de João de Barros, no Prólogo da Década III: «E como a Historia he hum agro, e campo, onde está semeada toda a doutrina Divina, Moral, Racional, e Instrumental, quem pastar o seu fruto, convertello-ha em forças de entendimento, e memoria para uso de justa, e perfeita vida». Náo é de estranhar, por isso, que, na obra de Barros, tenham colhido matéria Giovanni Botero, para a sua colectânea de Apoftegmas e Fernando Alvia de Castro para os seus Aphorismos y exemplos politicos e militares, tăo ao gosto da sensibilidade de finais do séc. XVI, inícios do XVII. 
raízes em Petrarca e Lorenzo Valla, que subordinam a cultura à moral ${ }^{29}$.

Esta ênfase, posta por Barros, no modelo paradigmático da história, cede lugar, em outros autores, ao papel que nela assume a expressão da verdade. Segundo Damiáo de Góis, «ho mais substançial que no screuer das Chronicas se requere», "hé com uerdade dar a cada hum ho louuor ou reprehensam que mereçe» ${ }^{30}$. Perfilham a ideia de Góis outros historiadores da gesta lusitana contemporânea, tais como, Fernão Lopes de Castanheda, Diogo de Couto, Gaspar Correia, que tiveram, como ele, as suas obras embargadas e alvo de censura. Apesar disso, o enaltecimento da figura do rei e seus cometimentos torna-se uma constante da historiografia portuguesa desta época, que era essencialmente nacional e dinástica e atribuía a maior importância aos triunfos militares e à coragem de um povo nas remotas paragens onde se estendia o império.

$\mathrm{Na}$ sua História do descobrimento e conquista da India pelos portugueses, Castanheda, por exemplo, dirige os prólogos antepostos aos livros I a IV aos soberanos e príncipes da casa real "pera quem parece que em especial se fez a história"31.

${ }^{29}$ Petrarca (1929), De sui ipsius et multorum ignorantia (1367), trad. de J. Bertrand. Paris: 60-65 e 85; L. Valla (1543), Dialecticae disputationes, I, 10, Basileae: 664.

${ }^{30}$ Prólogo da Crónica do Felicíssimo rei D. Manuel, 2 vols. Coimbra, vol. I : 2.

${ }^{31}$ Vide o Prólogo do Livro I, dirigido ao rei D. João III: Castanheda, Fernão Lopes de (1979) História do descobrimento e conquista da Índia pelos portugueses (livros I-IV). M. Lopes de Almeida ed. Porto: 3. 
Já Rui de Pina, no prólogo que antecede a sua crónica do rei D. Duarte se pronuncia em termos semelhantes ${ }^{32}$. Aliás, esta ideia surge a cada passo, quer nos prólogos, quer nas dedicatórias de traduçóes de obras históricas, de autores antigos ou contemporâneos. É o caso da Histoire de Portugal de Simon Goulard, que é, nos primeiros doze livros, a tradução do De rebus Emmanuelis gestis de D. Jerónimo Osório e, nos oito restantes, uma tradução da História de Castanheda. Nas palavras que a introduzem, Simon Goulard esforçase por demonstrar que a história de Portugal, agora apresentada a público, favorece o amor pela virtude, o ódio do vício, aprofunda o conhecimento do homem e dá liçóes de prudência política e militar. Se assim não fosse, de nada lhe valeria tê-la traduzido ${ }^{33}$.

Numa época em que o regalismo se começava a afirmar, por influência do direito romano, e abria caminho à teoria da soberania de estado, formulada por Jean Bodin, nos seus Six livres de la republique, o posicionamento doutrinário, adoptado pelo enunciador do discurso histórico, propiciava certas relaçóes conceptuais entre a obra histórica e os tratados de parénese e política.

${ }^{32}$ Rui de Pina (1977), Crónicas M. Lopes de Almeida ed. Porto: 487-488, afirma «a doutrina hystorial, polo grande provimento dos verdadeiros enxemplos passados que consigo teem, he assi doce e conforme a toda a humanidade [...] a invenção e cuidado deste Officio d'escrever de huma onestidade, e razam a quaaesquer boós, e vertuosos por seu galardam se possa atribuyr, ainda por huã outra spicialidade d'obrigatorios exemplos, e singulares merecimentos, aos Reys, e Principes mais propriamente se deve».

${ }^{33}$ Vide o texto transcrito por Villey 1912: 46-49. 
O elogio da figura do rei, suas virtudes e acçóes, de que o Panegírico de D. João III de João de Barros - elaborado por inspiraçáo do panegírico de Trajano de Plínio o Jovem - é um exemplo acabado, dá lugar, na historiografia portuguesa, ao olhar planetário que as grandes descobertas e o desenvolvimento científico vieram proporcionar. A exaltante atmosfera moral, aliada à consciência da hiperidentidade que caracteriza os homens de Quinhentos, transparece na prosa histórica em vulgar e em latim. Ganha forma a história monográfica - que empenhou humanistas como Diogo de Teive e Damião de Góis - onde se relatam episódios, em que o sensacionalismo tem um lugar de relevo.

No seu Commentario sobre os sucessos dos portugueses, no cerco de Diu, no ano de 1546, exalta Teive os feitos dos portugueses e apresenta, na imortal língua latina, às geraçôes vindouras, o valor militar dos homens da sua época.

Teive, à maneira clássica, regista as falas das personagens intervenientes, dá-lhes voz ${ }^{34}$, e, para tornar

${ }^{34}$ É este um processo que caracteriza a prosa histórica, desde os autores gregos do séc. V. Dioniso de Halicarnasso vai debruçarse, no seu Ad Pompeium Geminum 18 (776), sobre a mímesis, a imitação de caracteres e emoçóes, que considera uma das qualidades do estilo da prosa histórica. Em seu entender, Heródoto era superior na imitação dos caracteres e Tucídides na imitação das emoçôes. Também Longino, no seu tratado Do Sublime 22. 1 fala da mimese, como termo da teoria da história, com referência a Heródoto e a Tucídides. Segundo Longino, "a imitação dos efeitos da natureza" foi conseguida por estes historiadores clássicos, que imitaram o homem na sua acção real e adaptaram a sua linguagem aos caracteres e emoçóes individuais. Cf. o bem documentado artigo de Gray 1987: 467-486. 
imparcial a sua narrativa histórica, apresenta muitas vezes os factos em alternativa hipotética.

Damiáo de Góis, com igual intenção de exaltar a expansão ultramarina, escreve diversos opúsculos em latim. Através deles, o humanista de renome internacional, amigo de Erasmo e formado no convívio com os grandes centros do Humanismo europeu, procura divulgar o renome do seu país, evidenciar a real dimensão da universalidade e diversidade do homem e apelar para a necessidade da evangelização pacífica. São sobretudo estas obras, corroboradas pela sua correspondência, que tornam conhecidos, por vezes com um sensacionalismo quase jornalístico, os feitos dos portugueses e os seus interesses temporais e espirituais.

O motivo da exaltação épica das glórias nacionais, que torna a história próxima da epopeia, surge nos nossos autores por inspiração clássica. Neste particular, serve de modelo Tito Lívio - o título das Décadas de Barros o comprova - que se aproxima tanto da Eneida de Virgílio como a obra histórica quinhentista da epopeia Camoniana.

Do ponto de vista semântico-conceptual, o louvor das glórias lusas tem por referência os feitos de gregos e romanos. Esta evocação da alteridade pelo processo da inversão, muito frequente no estilo e expressão colorida de Heródoto ${ }^{35}$, funciona como princípio heurístico e concorre para a elaboração de uma representação do

${ }^{35}$ Vide Hartog 1980: 225-237 (cap. I "Une rhétorique de l'alterité"). 
mundo: os portugueses são superiores aos antigos pela sua missão evangelizadora, pela propagação da fé, que os anima.

Se a expressão do ideal heróico se vislumbra entre nós, desde tempos recuados, desde a crónica sobre a tomada de Ceuta, o De Septensi bello, de Mateus de Pisano, nas oraçóes de obediência proferidas perante a Santa Sé por um D. Garcia de Meneses em $1481^{36}$ ou por um Dr. Vasco Fernandes de Lucena em 1485 ou ainda por um Diogo Pacheco em $1515^{37}$, não é menos verdade que o paralelismo com os valores e os heróis paradigmáticos da Antiguidade se torna um verdadeiro topos no nosso humanismo, tanto nas obras em prosa, como na poesia.

É que a poesia, mais universal do que a história, segundo a definiçáo de Aristóteles ${ }^{38}$, exprime muitas vezes, entre nós, nesta época, a essência extraída dos ensinamentos da história.

Neste contexto, não admira que, de par com a componente ética, se definam, por inspiração de Cícero e Quintiliano, as dimensóes retórica e pedagógica da história. Quintiliano (Inst. Orat. 10. 1. 20-26) aconselha o jovem orador a ler, para sua formação, os oradores, os historiadores e os filósofos. É neste capítulo I do livro X $2-25$.

${ }^{36}$ Vide a oração latina e tradução portuguesa de Ramalho 1985:

${ }^{37}$ Rogers 1958: 105.

38 Aristóteles, Poética, 1451 a 36-1451 b 10. Quintiliano, dentro da tradição primitiva de uma histórica heróica, afirma na Institutio Oratoria (10.1.31) que a história está muito próxima da poesia e que aquela é uma forma de poema em prosa. 
que Quintiliano estabelece as ligaçôes culturais entre a história e a eloquência ${ }^{39}$.

No que se refere à história e à sua dimensão retórica, é de interesse lembrar que o italiano Lorenzo Gambara, no seu Tractatio de perfectae poeseos ratione, ou seja, no seu tratado 'sobre os motivos da perfeição em poesia', que data de 1576, ao aludir ao papel da história na inuentio humanista, isto é como manancial de argumentos, pôe em destaque a obra histórica de D. Jerónimo Osório - o seu De rebus Emmanuelis gestis e invoca o interesse e proveito da sua leitura, o seu valor moral ${ }^{40}$. Este juízo literário da prosa histórica do Cícero português, feito por um autor estrangeiro, manifesta não só o conhecimento universal da nossa história, quando escrita em latim, como ainda o apreço pela arte de a escrever.

Em Portugal, apesar de não haver nenhum tratado sistemático, que faça uma reflexão sobre o papel da história antiga, as concepçóes dos nossos autores inserem-se numa linha de feição tipicamente humanista ${ }^{41}$. Historiadores, autores de panegíricos,

${ }^{39}$ Vide, a este propósito, Cousin 1967: 576 e 582.

${ }^{40}$ Weinberg, Bernard ed. (1972): (vol. 3) 232: “Sed et postea consecuta sunt praeclarissima hominum gesta, quibus divina dextera usa est vel in Galiis, Germania, Anglia, Hispanis, Indiis [Osorius de rebus Indicis orientis et alii], ad fidem convertendis uel ad Hierosolimam recipiendam et ad belli sacri expeditionem, in quo praeclarissimi imperatores extiterunt. Quorum historiae et poemata si in scholis publiceque ac privatim legerentur, maximum ad christianam rempublicam commodum et pietatis robur accederet”.

${ }^{41}$ A este propósito, vide Macedo 1982: 98. 
de orações de sapiência, de tratados pedagógicos, de parénese e pedagogia política, todos repetem o valor moral do exemplo histórico ${ }^{42}$. Além disso, estes últimos incluem na ratio studiorum, ou seja no programa de estudos que propóem, a história como disciplina formativa do carácter e repositório de argumentos, indispensável à arte de bem falar, à eloquentia, que distingue o homo urbanus do Renascimento - de que se torna cartilha universal Il cortegiano de Baldassare Castiglione, dedicado - em homenagem à gentileza e urbanidade dos portugueses - ao nosso cardeal D. Miguel da Silva.

A ratio studiorum, proposta pelos pedagogos italianos do Quattrocento, em que o estudo da história é primordial, vai servir de referência à pedagogia humanista, que vigora por mais de um século.

O regulamento da Schola Aquitanica - isto é do Colégio universitário de Bordéus - elaborado pelo nosso André de Gouveia, que influiria no plano de estudos do Colégio das Artes, que este humanista viera fundar em Coimbra, em 1548, dá grande importância ao estudo dos historiadores clássicos. Os humanistas eram unânimes em considerar a história uma disciplina de grande utilidade pedagógica, verdadeiro manancial de exempla, que, além de enriquecerem a inventio retórica, forneciam uma enorme variedade de ensinamentos de moral privada e de comportamento civil e político.

${ }^{42}$ Entre os historiadores, é exemplo acabado João de Barros, não só nas Décadas, como nos Panegíricos de D. João III e da Infanta D. Maria ou ainda na Crónica do Imperador Clarimundo. 
É esta a posição assumida por Diogo de Teive e D. Jerónimo Osório, para falarmos apenas de dois pedagogos humanistas, representativos do pensamento histórico entre nós.

Nestes termos se pronuncia Teive, na Institutio Sebastiani primi, em tradução de Francisco de Andrade: "Natureza he da historia com grão gosto/ Animos recrear, e entendimentos/ E ensinar a fugir dos máos costumes/ Seguir os que são bons. A qual por isso/ Se chama com razão Mestra da vida" 43 .

Noutros passos, sublinha ainda o humanista bracarense o papel que deve desempenhar na instruçáo e educação integral do jovem príncipe ${ }^{44}$.

Jerónimo Osório, no seu extenso tratado, em diálogo, de Regis institutione et disciplina, pôe na boca de Lourenço Pires de Távora a defesa da educação cavaleiresca, das armas em detrimento das letras ${ }^{45}$. O ensino do príncipe devia fazer-se sobretudo pelo recurso ao exemplo e estímulo, colhidos nos feitos gloriosos, praticados pelos antepassados da história de Portugal $(\mathrm{I} .276 .33-42)^{46}$. A sua preparação literária deveria

${ }^{43}$ Teive, Diogo de (1786) Epodos que contèm sentenças úteis a todos os homens, A's quaes se acrescentão Regras para a Boa educação de hum principe. Trad. no vulgar em verso solto por Francisco de Andrade (conforme à ed. de Lisboa, 1565) Lisboa, na Of. Patr. de Francisco Luiz Ameno, MDCCLXXXVI: 158; (texto latino) 157:

${ }^{44}$ Ibidem: e.g. 123-125; 137-141.

${ }^{45}$ Vide o estudo sobre esta, em Soares 1994.

${ }^{46}$ Osório, D. Jerónimo (1592): Hieronymi Osorii Lusitani, Episcopi Algarbiensis, Opera omnia, Hieronymi Osorii nepotis Canonici Eborensis diligentia. In unum collecta, et in Quattuor uolumina distributa. Ad Philippum I Portugaliae regem inuictissimum. Romae, Ex Bibliotheca Georgij Ferrarij MDXCII. A indicação dos passos, 
resumir-se a aprender a ler e a escrever e, pormenor de interesse, a conhecer os poetas latinos e a história romana, para não ser considerado completamente ignorante nestas matérias, de todos conhecidas ${ }^{47}$.

Esta argumentação, a iniciar o tratado, dará lugar, logo de seguida, à proposta de uma educação integral: o rei deve ser instruído palaestra et litteris et religione, isto é, nas diversa componentes, física, intelectual, moral e religiosa.

O plano de estudos que propóe, que se estende de finais do livro IV a cerca de metade do livro V (I.382.58404.6), inclui as tradicionais disciplinares do triuium e do quadriuium e ainda a história, a poesia, a pintura, a escultura, o desenho, num programa verdadeiramente humanista, que o Panepistemon de Poliziano, preconiza ${ }^{48}$.

Além disso, Osório ao propor para o ensino da gramática os autores que pela sua mensagem moral e pela latinitas se impóem à consideração do educando, selecciona os historiadores César, Salústio, Tito Lívio ao lado de Cícero, Virgílio e Horácio (I.383.23-37).

Esta dependência dos autores do nosso humanismo ao modelo histórico da Antiguidade, que se

nos Opera Omnia, comporta o número do tomo, seguido do da coluna e das respectivas linhas.

${ }^{47}$ Ibidem, I. 276. 58-62: Quod uero ad litteras attinet, legere, et scribere sciat, et aliqua ex parte Latinos poetas, et Romanam historiam attingat; ne omnino rerum earum, quae sunt omnibus peruulgatae, rudis existimetur.

48 Sobre a importância que assume no humanismo renascentista um curriculum alargado à história, à poesia, à ética e às artes da pintura, escultura, arquitectura e desenho, incluídas também no Panepistemon de Angelo Poliziano, vide Burke 1987, 3a ed.: 51-62. 
define dentro de padrôes éticos, que estão de acordo com os valores essenciais do cristianismo, rejeita à partida a concepção pragmática da história, que se afirma com alguns historiadores de finais do séc. XV, princípios do XVI.

Se a produção histórica da antiguidade grecoromana, a partir do séc. XIV, desempenha um papel significativo na consolidação do conceito de estado e na definição dos direitos e deveres de governantes e governados, dentro de uma cosmovisão, onde a moral tem o seu império, é também com base na história antiga que Maquiavel vai construir o seu modelo de príncipe e fornecer-lhes as directrizes adequadas ao êxito, que estarão na base da concepção moderna da política ${ }^{49}$.

Os fundamentos da sua teoria de estado colhe-os Maquiavel em Políbio (Historiae, VI, 5, 6): diferentemente de Aristóteles, considera que a origem, a génese de um estado está na violência. Maquiavel baseia as suas consideraçóes teóricas sobre a forma de se constituir uma república e sobre a melhor forma de conservar o poder, na reflexão que faz sobre a teoria de anacyclôsis, desenvolvida por Políbio no livro VI, que ele comenta nas suas Histórias Florentinas ${ }^{50}$. Além de

${ }^{49}$ O Hieron de Xenofonte, que designa por De tyrannide título que Leonardo Bruni lhe dá na sua tradução latina - e o livro V da Política de Aristóteles estáo na base das considerações feitas no capítulo XXI de Il principe. É, no entanto, na terceira parte da sua obra (capítulos XV-XXIII), que diz respeito às relaçôes do príncipe com os seus súbditos e ainda com a sua "entourage", que Maquiavel quebra todos os laços com os postulados da política de inspiração clássica.

${ }^{50}$ Sobre a importância do livro VI de Políbio no pensamento do 
Políbio, inspira-se também em Tito Lívio ${ }^{51}$, os dois historiadores que traçaram as coordenadas que deram forma à grandeza de Roma. Serve-lhe ainda de modelo a obra de Tácito, representante do pragmatismo histórico na Antiguidade latina ${ }^{52}$.

Também Jean Bodin, na sua obra Les six livres de la république (cap. I do livro IV), alude ao tema das mutaçôes, às conuersiones rerumpublicarum - expressão que figura na edição latina da obra - e, ao tentar uma formulação sistemática e jurídico-política da teoria de estado, apoia-se no direito romano e na reflexão crítica dos modelos da antiguidade greco-latina, dos pensadores Platão, Aristóteles, Xenofonte, Plutarco, Cícero e dos historiadores Políbio, Tito Lívio, Tácito ${ }^{53}$.

Curioso é notar que a obra do Florentino, apesar de criticada e condenada, vai influir - a par da de Jean Bodin $^{54}$ - na definição da "verdadeira razão de estado",

séc. XVI, com referência particular ao pensamento de Maquiavel, vide Sasso 1980: 441 - 462.

${ }^{51}$ A Maquiavel se devem os Discursos sobre a Primeira Década de Tito Livio, cujo título mostra a sua preocupação pelo destino da sua cidade e a esperança de se igualar ao modelo clássico. Bem diversa de $I l$ principe é esta obra, que se insere na linha da tradição humanista. A própria teoria da melhor forma de governo que nela apresenta (cap. II), de acordo com Políbio e Cícero, é a constituição mista, que vigorou na Roma republicana.

${ }^{52}$ Vide Develin 1978: 64-95.

${ }^{53}$ Vide, a este propósito, Mesnard 1977: 476-477.

${ }^{54}$ Foi o já designado "racionalismo maquiavélico de Bodin" um dos motivos de repúdio da obra do jurista francês entre os teorizadores hispânicos da Contra-Reforma. Apesar de tudo, Bodin conseguiu infiltrar-se na Península Ibérica, que dele recebeu, nesta época, o conceito de soberania. Vide, a este propósito, Albuquerque 1978: 77 e sqq. e 121 e sqq. 
ad maiorem Dei gloriam dos doutrinadores jesuítas ${ }^{55}$ e na afirmação do tacitismo - corrente, que se apoia no modelo pragmático da história de Tácito e conhece grande fortuna nos finais do século XVI e ao longo do século XVII. Em Portugal, todavia, se alguns reflexos se podem apontar - Fernando Alvia de Castro, no séc. XVII, recolhe os melhores aforismos políticos de Tácito - estes correspondem latu modo, ao Tácito cristianizado.

Se exceptuarmos certos particularismos, na história do pensamento europeu, a leitura paradigmática da história, de inspiração cristá, perdura desde o séc. $\mathrm{XV}$ aos finais do séc. $\mathrm{XVI}^{56}$. Num tâo longo período do humanismo europeu, esta continuidade de sentido é interrompida, mas também enriquecida por certas interpretaçôes individuais, como é o caso de Montaigne, que no seu estoicismo céptico, marcadamente influenciado por Epicteto e Séneca, recusa, na interpretação da história, qualquer modelo filosófico, religioso e ético, em nome da escrita da verdade individual, de que os Éssais são documento ${ }^{57}$. Apesar

55 Foi grande a importância da obra de Giovannni Botero (1589), Della ragion di stato, que se torna um verdadeiro marco na definição da "verdadeira razáo de estado" dos jesuítas e no desencadear do tacitismo.

${ }^{56}$ É este o modelo que se impóe à consideração de teorizadores como Jean Bodin (Methodus ad facilem historiam cognitionem de 1566), ou ainda, entre os espanhóis, Luís Vives e António Viperano. Vide J. Bodin (1951), La méthode de l'histoire, P. Mesnard ed., Paris. Vários são os trabalhos que se ocupam da história e metodologia historiográfica em Jean Bodin. Vide Bodin 1985.

${ }^{57}$ Vide Stierle 1972: 176-198. 
disso, Montaigne confessa que em matéria de livros «L'Histoire, c'est plus mon gibier» (1. 26) , aludindo a D. Jerónimo Osório, «l'evesque Osorius le meilleur historien Latin de noz siecles» (1. 14).

Um aspecto importante que se prende com a grandeza da nossa factualidade histórica, no século de ouro europeu, que perdura hoje ainda na memória de outros povos, é a gesta dos Descobrimentos, que serviu de pórtico à Idade Moderna, e desempenhou um notável papel, no domínio da experiência e do conhecimento universais.

Exemplos expressivos são a Peregrinação de Fernão Mendes Pinto, os Colóquios dos simples e drogas de Garcia de Orta e as obras históricas, como as Décadas de Barros, «singularmente célebres pela geografia»" ${ }^{58}$, ou a História do descobrimento e conquista da Índia pelos Portugueses que, na tradução de Nicolas Grouchy, divulgou, na língua francesa, os termos exóticos do vocabulário oriental ${ }^{59}$. Também Os Lusíadas documentam, de forma eloquente, a utilização poética do conhecimento científico $^{60}$.

$\mathrm{Na}$ historiografia do século XVI, as narrativas marítimas de países desconhecidos, de fenómenos naturais, de paragens de outras latitudes e climas, manifestam, de par com a presença do maravilhoso, a

${ }^{58}$ É este o modelo que se impóe à consideração de teorizadores como Jean Bodin (Methodus ad facilem historiam cognitionem de 1566), ou ainda, entre os espanhóis, Luís Vives e António Viperano. Vide J. Bodin (1951), La méthode de l'histoire, P. Mesnard ed., Paris. Vários são os trabalhos que se ocupam da história e metodologia historiográfica em Jean Bodin. Vide Bodin 1985.

${ }^{59}$ Vide Carvalho 1964: 9-36; Le Gentil 1973: 31-46.

${ }^{60}$ Vide Ribeiro 1980: 153-199. 
importância que assume a experiência, a componente realista e empírica. Sáo frequentes as marcas da enunciação 'eu vi', 'eu ouvi', que servem no discurso do narrador para dar maior credibilidade aos factos, que apontam para uma história contemporânea, baseada nos pressupostos teóricos de Tucídides. Além disso, a verdade factual, nutrida por estas marcas de enunciação é a cada passo confrontada com os relatos míticos de um Heródoto, com a Cosmografia de um Ptolomeu, a Geografia de um Estrabão, ou a ciência de um Pompónio Mela ou de uma História Natural de Plínio. As crónicas de João de Barros, de Castanheda, de Diogo do Couto, ou de forma mais evidente o Roteiro de Lisboa a Goa e o Tratado de Esfera de D. João de Castro, as obras de Garcia de Orta, de Duarte Pacheco Pereira, de Pedro Nunes, dáo-nos a cada passo exemplos significativos ${ }^{61}$.

Poderemos concluir que, na época do Renascimento, a história, além de se afirmar como género literário, que se impóe pela arte da escrita, como opus oratorium, é disciplina formativa do carácter e repositório de paradigmas, é manancial de exempla que informam a tradição retórica, é ponto de referência da exaltação épica das glórias nacionais, é suporte de

${ }^{61}$ A título de exemplo, vide e.g. os passos das Décadas de Barros (D. II, l. I, cap. III; D. III, l. II, cap. I; D. III, l. IV, cap. I), onde as referências a Ptolomeu, Estrabáo e aos antigos servem para identificar e localizar ilhas e certas regiôes orientais, agora conhecidas. O mesmo acontece no Roteiro de Lisboa a Goa (1538), ed. de Fontoura da Costa, Lisboa, 1939, nos passos em que D. João de Castro faz a descrição das Ilhas Canárias (p. 14-16), ou das Ilhas de Cabo Verde (p. 23-25). 
novos modelos ideológicos e de formulação política em termos modernos, é fundamento de novos horizontes culturais e científicos é, em suma, "hum espertador do entendimento".

Conferência proferida na Faculdade de Letras/ UFRJ, no âmbito dos Cursos de Pós-graduaçấo em Letras Clássicas, em que nos foi grato homenagear a figura do Mestre, que também o foi desta Universidade, o Prof. Doutor Américo da Costa Ramalho. 


\section{BibLIOGRAFia}

Albuquerque, Martim de (1978), Jean Bodin na Península Ibérica (ensaio de história das ideias politicas e de direito público). Paris.

ASENSIO, Eugenio (1974), "La lengua compañera del Imperio" in Estudios portugueses. Paris: 1-16.

Atkinson, D. M. (1962), “O estilo narrativo de Fernão Lopes”, Ocidente 72: 255-230.

Baron, Hans (1966), Crisis of the early Italian Renaissance. Princeton-New Jersey.

Bodin, Jean (1985), Actes do Colloque interdisciplinaire d'Angers - Jean Bodin. Angers.

Burke, Peter (1987, 3a ed.), The italian Renaissance (Culture and Society in Italy). Cambridge.

—_ (1992), O mundo como teatro. Estudos de antropologia histórica (trad. Port.) Lisboa.

Carvalho, J. G. Herculano de (1964), "O vocabulário exótico na Histoire des Indes (1553)", in Estudos Linguísticos, I. Lisboa: 9-36.

Georges Le Gentil (1973), 'Nicolas de Grouchy, traducteur de Castanheda', Bulletin des Études Portugaises et de l'Institut Français au Portugal 4: 31-46.

Cochrane, Eric (1981), Historians and historiography in the Italian Renaissance. Chicago. 
Cousın, J. (1967), Études sur Quintilien, Amsterdam.

Develin, R. (1978), "Tacitus and techniques of insidious suggestion”, Antichthon 17: 64-95.

FARAL, E. (1967), Recherches sur les sources latines des contes romans courtois du Moyen-Âge. Paris.

Genette, G. (1979), Discurso da narrativa. Lisboa.

Gray, Vivienne (1987), "Mimesis in Greek historical theory”, American journal of philology 108: 467-486.

Hartog, François (1980), Le Miroir d'Hérodote. Essai sur la représentation de l'autre, Paris.

Kristeller, P. O. (1979), Renaissance thought and its sources. New York.

Le Gentil, Georges (1973), "Nicolas de Grouchy, traducteur de Castanheda", Bulletin des Études Portugaises et de l'Institut Français au Portugal 4: 31-46.

López Eire, Antonio (2008), "La influencia de la Retórica sobre la Historiografia desde el Helenismo a la Antigüedad Tardía”, Falia dixit 3: $1-32$.

Martins, Mário (1977), "Frases de orientação nos romances arturianos e em Fernão Lopes”. Itinerarium, ano XXIII, no 95: 3-24.

Mattoso, José (1988), A escrita da história. Teoria e métodos. Lisboa. 
Mesnard, P. (1977), L'essor de la philosophie politique au XVIe siècle. Paris.

Monfrin, J. (1972), “La connaissance de l'Antiquité et le problème de l'humanisme en langue vulgaire dans la France du XVe siècle" in The Late Middle Ages and the dawn of humanism outside Italy, Mediaevalia Lovaniensia, series I / studia I, Leuven-The Hague, 152-154.

Narducci, Emanuele (2009), Cicerone. La parola e la politica. Bari

Nolhac, Pierre (1965), Pétrarque et l'Humanisme. Paris: vol. II, cap. VI "Pétrarque et les historiens romains".

Ramalho, A. Costa (1985), Latim Renascentista em Portugal - Antologia. Coimbra.

Ribeiro, Orlando (1980), "Camóes e a geografia", Finisterra 15: 153-199.

Rogers, Francis M. (1958), The obedience of a king of Portugal, translated, with commentary. Minneapolis.

Sasso, G. (1980), Niccolò Machiavelli. Storia del suo pensiero politico. Bologna.

Soares, Nair N. Castro (1994), O Príncipe ideal no século XVI e a obra de D. Jerónimo Osório. Coimbra.

__ (2003), "História Antiga e Humanismo: a História he hum espertador do entendimento", Caliope 11: $9-32$ 
Stierle, K. (1972), "L'Histoire comme Exemple, l'Exemple comme Histoire. Contribution à la pragmatique et à la poétique des textes narratifs", Poétique 10: 176-198.

Ullmann, Walter (1977), Medieval fondations of Renaissance Humanism. London, 1977: tr. it. (1980), Radici del Rinascimento. Roma-Bari.

Villey, P. (1912), Les sources d'idées. Textes choisis et commentées. Paris.

Weinberg, Bernard ed. (1972), Trattati di poetica e retorica del Cinquecento, 3 vols. Bari. 
Na CORRESPONDÊNCIA de ERASMO: O HUMANISTA, AS LETRAS E A CIDADE

\author{
Jorge A. Osório
}


Numa longa carta escrita no primeiro dia de fevereiro de 1523 a João Marco Laurino, deão do Colégio de S. Donaciano, em Bruges, Desidério Erasmo de Roterdão, aludindo ao convite do senado de Zurique para que aceitasse o direito de cidade que lhe era oferecido, respondia que preferia ser cidadão do mundo inteiro a sê-lo de uma única cidade (V, ep. 1342) [As cartas citadas serão referenciadas pelos volumes e pela numeração da edição de P. S. Allen e H. W. Garrod do Opus Epistolarum Desiderii Erasmi Roterodami, 1906-1947]. Não era a primeira vez que expressava essa sua visão da condição universal ou católica do homem cristão, em quem revia a sua própria pessoa; dez anos antes exprimira esse mesmo ponto de vista e haveria de o retomar depois mais do que uma vez; por exemplo em maio de 1529, reportando-se a um dos Adágios, escrevia que a pátria é o lugar onde se está bem, do ponto de vista cristão, claro (VIII, ep. 2158), ideia reforçada em carta do mesmo ano (VIII, ep. 2196), glosada em 1531 na forma onde o meu pobre corpo for enterrado não tem grande importância (IX, ep. 2419, jan. 1531).

Ao terminar a carta que, em julho de 1529, envia a Johann Choler, escrevia o seguinte:

"Sempre me deixei encantar pelos grandes edifícios e as grandes cidades; e apesar de raras vezes pôr o pé fora do meu 
quarto, sinto prazer em viver nas cidades muito populosas. Trata-se de um sentimento instintivo, que não deixa de ter alguma razão. Nessas cidades há menos traços visíveis do campo e as coisas boas estão aí mais disponíveis e em maior abundância. Enfim, é mais fácil encontrar amigos honestos numa grande multidão de homens do que num pequeno número" (VIII, ep. 2195).

Podemos dizer que nestes dois parágrafos se encontram os elementos essenciais do tema que nos propomos focar nestas linhas. Elementos que sinalizam, até pela frequência com que são convocados, a psicologia e a vida do próprio humanista. Para os completar falta só dizer que, a articulá-los, há que considerar o gosto, se não mesmo a necessidade quase impulsiva, de viajar, ou melhor, de mudar de poiso. Não será certamente despropositado falar mesmo da presença de uma ansiedade, de uma inconstância e às vezes até de uma inquietação, que, no entanto, não aparece vivida na forma de um drama interior do género espiritual, conducente a uma experiência ascética que, por exemplo, implicasse a mortificação corporal.

Aquele factor que, desde muito cedo, condiciona e orienta assumidamente a vida de Erasmo pode sintetizar-se na dedicação, que se tornará obsessiva, ao estudo das letras, naquilo que o termo significava no seu tempo, nesse amplo campo semântico que ia desde o estudo concreto das línguas antigas, sobretudo, claro, o latim, e dos textos nelas escritos e conservados, até às tarefas de os fazer publicar através da imprensa e às consequências científicas, filológicas, doutrinárias, 
filosóficas, morais, políticas, religiosas que desse estudo e desse conhecimento decorriam. Por causa delas, Erasmo atravessa este vasto terreno, não só no sentido metafórico, mas também em sentido próprio: até à idade dos cinquenta anos foi um incansável viajante, que percorreu os principais centros da Europa culta, ou seja o que já se caracterizou como a Europa do Humanismo. A questão da cidade insere-se nesta perspectiva.

Mais do que em qualquer outra zona da sua extensíssima produção escrita, é na enorme correspondência epistolar que podemos colher os dados pertinentes para o assunto em causa. E podemos fazê-lo tendo presente o que escrevia Eça de Queirós na apresentação da Correspondência de Fradique Mendes, a propósito da utilidade de uma correspondência epistolar: a respeito do seu autor, ela permite revelar

"com mais saliência a sua "personalidade" - o conjunto de ideias, de gostos, modos, em que tangivelmente se sente e se palpa o homem."

Ora não será fácil separar este palpar o homem do tema presente: Erasmo e a cidade.

Como certamente evidenciaráo os testemunhos de seguida utilizados, a cidade é o local natural para a vida de Erasmo. No seu pensamento - e era um autor que não pensava de forma sistemática, mas por temas que foram sendo retomados e glosados ao longo dos anos (Margolin, 1973) -, a cidade não é perspectivada na antinomia com o campo, táo do gosto de muita literatura ficcional, 
lírica ou mesmo moralizante do tempo, mas quase como equivalente, no plano da utopia, à comunidade dos cristãos, à ecclesia. Para tal, há que convocar alguns momentos em que Erasmo se pronuncia sobre essa outra comunidade cristã que é o mosteiro.

$\mathrm{Na}$ já referida carta escrita de Lovaina a Martinho Dorp em 1518, que antecede, como dedicatória, a edição desse ano do Manual do cavaleiro cristáo, encontra-se um passo que merece alguma atenção. Já na parte final, evocando o contraste, nele tão corrente, entre a religiosidade dos seus contemporâneos e aquela que, bastante utopicamente, considerava ter sido a dos primitivos cristáos, que ele via sobretudo através dos textos da Patrística grega, observa o seguinte:

"Tais foram os primórdios do monaquismo, tais os patriarcas, enquanto agora chamamos monges àqueles que se intrometem mesmo no seio dos assuntos mundanos;"

e colocava a pergunta retórica: "porque é que reduzimos de maneira táo evidente [por culpa dos frades, claro] a profissão de Cristo, que Ele quis fosse a mais alargada possível?" É que, perguntava a Dorp, "se queremos ser sensíveis a expressóes de maior impacto, que outra coisa não é a cidade senão um grande mosteiro?" (Holborn, 1964). A cidade - entenda-se, a cidade numa perspectiva cristã - devia ser, em boa verdade, como que um mosteiro, ou seja uma igreja (ecclesia) ou comunidade de pessoas vivendo segundo os preceitos evangélicos. 
A similitude não era nova em Erasmo. Quatro anos antes, numa carta ao seu antigo companheiro de juventude na comunidade agostiniana de Steyn, Servais Rogério (I, ep. 206, jul. 1514), usa-a com o mesmo objectivo:

"Como é muito mais conforme ao pensamento de Cristo ver o conjunto do universo cristáo como uma única casa e quase como um só mosteiro onde todos seriam cónegos e freires de uma mesma ordem;"

para tal bastaria colocar a essência da religiáo no sacramento do baptismo e não se preocupar com o lugar onde se vive, mas antes com o facto de viver bem.

Erasmo começara a sua vida nessa comunidade da regra de Sto. Agostinho; algumas das primeiras cartas conservadas - que, no entanto, não tomou a iniciativa de publicar - oferecem-nos a imagem de um jovem entusiasmado com o estudo das letras, concentrado em treinar-se no latim por meio de ensaios em verso e em prosa e em conhecer o maior número possível de autores clássicos. Não repugna aceitar que essa correspondência, particularmente a trocada com Cornélio Gerardo e Servais Rogério, legitima a opiniáo de que Erasmo possuía "um temperamento delicado e ardente, faminto de ternura, muito pouco feito para a vida do claustro" (Halkin, 1969); na verdade o sentimento da amizade, no sentido de cimentador de uma solidariedade que, globalmente, sempre haveria de idealizar em termos de convivência cristá, constituiu para ele um elemento 
central, não só em termos psicológicos, mas também como fundamento da ideia de que o cristão deve ser animado pela disponibilidade de aceitar um qualquer lugar para a sua vida terrena, porque isso não constituía factor determinante da espiritualidade. Era um jovem de vinte anos quando numa carta, talvez de 1488 , se insurgia contra a calma e a indolência desse companheiro e amigo Servais Rogério, que optara por ficar no convento em vez de aspirar à busca do estudo promissor das letras; justificando-se, Erasmo evocava o exemplo dos

"homens mais ilustres de outrora que não hesitaram, para adquirir as letras, em trocar a sua doce pátria por um exílio triste, em visitar terras estrangeiras queimadas pelo sol, em suportar os inúmeros perigos do mar tempestuoso, enfim em suportar todo o género de sofrimentos e de despesas" (I, ep. 15).

Como é que poderia ele aceitar ficar confinado às paredes de um convento, quando a sua grande paixão eram o estudo, os livros, as bibliotecas? Isto no tempo em que a sua própria pátria, a Holanda, vivia à margem dessa modernidade do saber, faltando-lhe os livros e aquele ligeiro sopro de melhor literatura que Rudolfo Agrícola - que recorda ainda ter visto aos doze anos - trouxera de Itália, conforme escreveria em 1523, no Catálogo?

O mosteiro, a cidade e as letras: a trilogia que condiciona Erasmo ao longo da vida e que se reflecte na correspondência. $\mathrm{Na}$ perspectiva do universalismo 
cristáo, não se trata de uma oposiçáo entre o mosteiro e a cidade; a recusa da vida conventual não significa a opção pelo modo de vida citadino, no sentido de mundano; como veremos, algumas das páginas mais impressivas pelo concretismo descritivo dizem precisamente respeito a cidades. Aliás não fala do convento em termos tão concretos como fala da cidade.

Fala do frade, mas distingue, como é bem sabido, entre o ideal e a realidade observável ou, pelo menos, vulgarizada. É significativo o que escreveu em Friburgo, em fevereiro de 1533: "monge é sinónimo de cume das virtudes heróicas, aquelas que atraem a benevolência e o favor dos bons;" se não se gosta da palavra, diz, use-se então isolado, solitário, mas entenda-se que esse isolamento náo se deve interpretar do ponto de vista material (nem os Cartuxos vivem isolados), antes como uma "barreira posta diante das más tendências", ou seja no plano espiritual. Vista por este ângulo, essa solidão implica uma "fraternidade que gera uma solidão feliz", que, por sua vez, não pode ser afectada pela vida social: "na Corte dos Príncipes, nas funçóes públicas, no seio das relações humanas é possível ser-se monge" (X, ep. 2771, fev. 1533). Por isso enaltece alguns, poucos é certo, frades, alguns franciscanos, como João Vitrier de Tournai, abade do mosteiro franciscano de Saint-Omer - aí Erasmo terminará a redacção do Manual do cavaleiro cristão, a sair em Lovaina -, que conheceu em finais de 1501, o qual nos sermóes valorizava mais a espiritualidade do que as práticas e as cerimónias religiosas e que ele, Erasmo, em 1521 colocava logo a seguir a John Colet na escala 
de homens que mais apreciava (IV, ep. 1211, jun. 1521) - ou entáo aquele Thierry de Munique que em 1532 diz ter conhecido cerca de quarenta anos atrás e em quem admira a piedade, a capacidade de pregar e a dureza de vida (X, ep. 2700, ago. 1532).

Nesta linha de pensamento se devem ler as afirmaçôes sobre a condição monástica largamente difundidas, como aquela de que

"o estado monacal não é a piedade; não passa de um género de vida, bom ou mau conforme a constituição do corpo e do espírito de cada um” (I, ep. 164, finais de 1501),

asserção tornada célebre por ser incluída logo em 1503 na primeira edição do Manual do cavaleiro cristão, segundo a qual monge não é piedade, mas género de vida, útil ou inútil de acordo com o hábito do corpo e do espírito que interessa a cada um" (Holborn, 1964), e reforçada na dedicatória da edição de 1518 a Paulo Volz: “a perfeição de Cristo está nos afectos, não no género de vida; está nos ânimos, não nos pálios ou nos alimentos" (Holborn, 1964; cf. V, ep. 1459, jun. 1524). Trata-se de um aspecto nuclear da obra, do pensamento e da doutrina erasmiana ao longo da vida; por isso, com toda a pertinência um grande estudioso pôde escrever que "o ideal monástico colocou Erasmo no caminho da verdadeira teologia” (Chantraine, 1971).

No plano espiritual e utópico o mosteiro e a cidade convergem, em oposição à realidade sociológica e historicamente observável a que os dois termos se 
reportam. Trata-se, naturalmente, de uma simplificação esquemática, mas sustentada largamente pelos textos do autor; esquemática, mas substancial. Ao tentar justificar, na já citada, mas pouco amistosa, carta a Servais Rogério, a recusa de regressar ao convento, escrevia o seguinte:

"Como é muito mais conforme ao pensamento de Cristo olhar para o universo cristão inteiro como uma única casa e quase como um único mosteiro onde todos seriam cónegos e frades de uma mesma ordem; e pôr o essencial da religião no sacramento do baptismo, e não dar importância ao lugar onde se vive mas ao facto de se viver bem,"

ou seja cristámente! Roger pretendia que ele, Erasmo, tivesse uma residência fixa, onde pudesse passar a velhice; porém, o impulso para a itinerância era mais forte e, sublinha ele, perfeitamente cristão: então não se louvavam as viagens de Sólon, de Pitágoras, de Platão; então não tinham os apóstolos, sobretudo S. Paulo, viajado tanto? (I, ep. 296, jul. 1514).

$\mathrm{O}$ percurso que pretende seguir e a figura que anseia dar de si mesmo implicam esta dimensão universal, quase apátrida, que necessita, para ser levada a cabo, da viagem. Deste modo, letras, amizade, mosteiro, cidade, viagem são temas ou referências que se articulam entre si, não na forma de um sistema de pensamento organizado, mas convocáveis segundo a oportunidade do discurso. Concretamente é o que se passa com a cidade.

Já em cima se convocou o passo de uma carta de 1529, ano importante na sua vida, onde proclamava o prazer que sinto em viver nas cidades mais populosas, ou seja 
naquelas onde os sinais da vida campesina fossem menos perceptíveis, onde as coisas boas estivessem mais disponiveis em maior abundância e onde fosse mais fácil encontrar amigos honestos. Isto foi escrito em Friburgo, cidade para onde se transfere em abril de 1529, deixando Basileia, a cidade onde vivia desde fins de 1521. Mudou-se porque as tensôes religiosas foram restringindo cada vez mais o ambiente à sua volta, apesar dos esforços que amigos e até mesmo adversários desenvolveram para que abandonasse a decisão. Mas como escrevia a António Fugger mal começava a instalar-se, tinha a esperança de que Friburgo fizesse justiça ao seu nome: "cidade da liberdade» (VIII, ep. 2192, jul. 1529). Dez dias depois escreve a Amerbach que esta cidade "me agrada pelos bons costumes: não ouço ninguém dizer mal de alguém” (VIII, ep. 2151).

"De basileiense tornei-me friburgense. Custava-me muito deixar o ninho a que me tinha acostumado durante tantos anos; mas tudo se passou melhor do que esperava, sobretudo no que diz respeito à minha saúde”,

escrevia ao jovem alemão Daniel Estibário, em 14 de maio do ano da mudança (VIII, ep. 2161).

Primeira impressão; mas três semanas depois de aí estar instalado, em carta a Willibald Pirckheimer, evoca a resposta que dera em Basileia a Oecolampádio na altura da partida: Ficarei alguns meses em Friburgo, e partirei para ir para onde Deus me chamar (VIII, ep. 2158).

Temos aqui um dos traços mais marcantes da personalidade de Erasmo, que é uma espécie de ansiedade 
ou inquietude relativamente ao lugar onde viver. Parece que ponto algum o satisfaz e o deixa sossegado. Basileia foi certamente, depois de Roma na fase anterior da sua vida, a cidade que mais o prendeu; para aí fora ido de Lovaina, com o fito de estar perto da tipografia de João Froben para poder acompanhar os trabalhos de impressão do seu Jerónimo, em dez volumes. E bem era preciso, pelo cuidado filológico que o texto implicava, sobretudo porque a revisão e a correcção se faziam não sobre provas, mas durante o processo de impressáo, o que encarecia muito a produção do livro (III, ep. 602, jul. 1517). E basta lembrar a carta escrita de Londres em maio de 1515, quando regressava ao continente, na qual evoca, com não disfarçada alegria, a azáfama que então ia na oficina frobeniana com a impressão desses dez volumes (II, ep. 334).

Há nele - é como se nunca se tivesse libertado dela - uma constante insatisfação quanto à ideia de ficar preso a um lugar; como se vai ver de seguida, sobretudo a partir de meados da década de 1510, isso alia-se às questóes de saúde; ou dizendo melhor, a sua saúde - os sofrimentos físicos de que sofre - passa a prender cada vez mais a sua atenção e a constituir motivo e justificação para as observaçóes que faz sobre as cidades onde habita. Por exemplo, numa carta do último dia de 1520 diz estar a pensar passar o veráo em Basileia ou talvez ir de novo a Itália (projecto que acalentou durante muito tempo, tendo mesmo iniciado a viagem, embora a náo pudesse continuar) (IV, ep. 1176, dez. 1520); ainda mal se havia instalado em Friburgo no veráo de 1529 e já escrevia a 
um amigo que decidira passar ali o inverno e no tempo da andorinha ir para onde Deus me chamar (VIII, ep. 2222, out. 1529). No ano seguinte, descrevendo de forma realista - procedimento discursivo a que recorre sempre para o tema da sua saúde - a doença que tanto o incomoda (vómitos, insónias, cólicas, um inchaço do lado direito da barriga, "como uma serpente cuja cabeça se tivesse fixado no umbigo, o meio do corpo enrolado em anéis e a cauda em direcção ao púbis, tendo depois virado para a esquerda)", denuncia a mesma inquietaçáo, escrevendo "que desde há bastante tempo que morro por partir daqui e ir para outro lugar;" e, no entanto, estava na cidade apenas há um ano (VIII, ep. 2355, jul. 1530)...

No entanto, esta inquietação e ansiedade bem patentes nas cartas, sobretudo deste período, tinham, com certeza, para ele o sentido e o valor da manifestação da sua independência de espírito e de pensamento, ou antes do receio de perder essa sua liberdade que tanto prezava, a qual, se lhe faltasse, seria como perder a vida (II, ep. 333, mai. 1515). Não obstante em 1531 ter comprado essa casa em Friburgo, cómoda e espaçosa, que não fora muito cara (IX, ep. 2534, set. 1531) - dois anos depois, diz a Erasmo Schets, seu agente financeiro: "Já investi mais de 800 florins em ouro na casa onde estou, apesar de que penso pôr-me a voar daqui" (X, ep. 2761, fev. 1533) -, em 1534 alega que "muitas coisas me incitam a ir embora, se tal me fosse possível"(XI, ep. 2961, ago. 1534). São anos difíceis, de dura resistência aos incómodos fisiológicos e às pressóes de natureza 
moral e religiosa; numa carta de um ano antes da morte, a propósito da notícia de que o papa Leão III lhe iria oferecer o chapéu cardinalício, afirma que já não está em idade para tais cargos e acrescenta: "o boi que eu sou náo aceitará o jugo” (XI, ep. 3049, ago. 1535), imagem que usa mais do que uma vez (ex. VII, ep. 1804, mar. 1527, a Tomás More).

Até 1514 deslocara-se pela Europa: Paris, Londres, Lovaina, Bruxelas, Veneza, Pádua, Roma, Ferrara são cidades que fazem parte desse percurso. Depois de 1514 serão sobretudo as cidades da Alemanha e dos Países-Baixos, onde permanecerá em períodos de variada duração; em 1527 instala-se definitivamente em Lovaina. Aí fará a sua residência habitual até finais de 1521, quando se passa para Basileia, que deixará em meados de 1529 para procurar refúgio em Friburgo, onde ficará até ao fim, embora tenha falecido em Basileia, em casa de Jerónimo Froben.

Mas com esta experiência toda de cidades - ele mesmo diz que conheceu muitas cidades e universidades -, poderemos perguntar-nos, tendo em conta que era um observador perspicaz, que observaçôes ou anotaçóes deixou sobre elas. Ou de outro modo: dizendo-se, mais de uma vez, especial apreciador da vida em cidades populosas, o que, se excluía o retiro no campo ou no convento, excluía também a vida de corte $-a$ nossa Corte [i. é a Corte imperial] é um tonel furado; tem sempre sede, não dá nada, escrevia em abril de 1533 (X, ep. 2795) -, que aspectos da cidade fundamentam essa sua preferência? 
Ora, para além da expressão da preferência pelos meios de tónica mais cosmopolita, aquilo que podemos encontrar nas suas cartas de elogio concreto de uma qualquer cidade nada tem a ver com motivos de natureza urbana. Não é o movimento citadino, nem os aspectos urbanísticos (ruas, praças, edifícios, aquedutos) que merecem ser referidos nos textos. Vive em Basileia oito anos e em Lovaina cerca de dois anos e meio, mas nada informa do ponto de vista urbanístico ou arquitectónico; quanto a Lovaina, limita-se a expressar o seu apreço pelo edifício do Colégio Trilingue, dizendo que "é honesto e de uma arquitectura que não deixa de ter elegância" (V, ep. 1221, jul. 1521). Mas os aspectos físicos desta e das outras cidades não fixam a sua atenção, a não ser quando e na medida em que se sente fisicamente afectado pelo seu ambiente. Por exemplo, apesar do ambiente cultural e universitário que encontrou em Lovaina, não a elogia nos termos encomiásticos do poema que André de Resende escreveu em 1530 sobre ela, louvando-a como a cidade onde a mocidade podia aprender as boas letras essenciais na guerra contra a barbárie.

Por Itália andara entre 1506 e o verão de 1509, quando volta a Inglaterra atraído por promessas de recompensas sedutoras que não chegaram a concretizar-se; demorara-se em várias cidades, mas da paisagem ou daquilo que viu nada referirá, a não ser em relação a Roma. Numa corajosa, porque fazia a defesa de Reuchlin, carta de maio de 1515 ao cardeal Riário falava do tormento que eram as saudades que tinha da cidade de Roma, lembrando-se "daquela liberdade, 
daquela perspectiva, daquela luz, daquelas avenidas, daquelas bibliotecas, daquelas agradáveis conversas entre eruditos", de quantas pessoas interessadas nos mesmos assuntos que ele "havia abandonado deixando Roma” (II, ep. 333); e nesse mesmo mês, escrevendo também ao cardeal Grimaldi, insistia nesse mesmo desejo de Roma cada vez que se lembrava das vantagens de que gozara na cidade, evocando

"a luminosidade e a localização da cidade mais célebre de todas, a doce liberdade, tantas bibliotecas riquíssimas, o convívio, delicioso entre todos, com tantos homens superiormente eruditos, tantas conversas eruditas, tantos testemunhos da antiguidade" (II, ep. 334).

Por essa época alimenta o projecto de regressar à cidade e aí viver o resto dos anos, "rodeado de homens muito eruditos e de bibliotecas extremamente ricas" (IV, ep. 1236 set. 1521).

É por este prisma que Erasmo aprecia as cidades, pelo cosmopolitismo das letras e dos letrados. Em 1505 dizia de Londres:

"Na verdade, há em Londres cinco ou seis homens perfeitamente instruídos nas duas línguas, tais que mesmo em Itália não os há parecidos” (I, ep. 187).

Idêntico juízo quanto a Veneza, lembrado dos amigos que aí conhecera (II, ep. 512, jan. 1517), e a Ferrara, cidade onde lhe fora possível usufruir do conhecimento de homens de letras e de religiáo como 
Celio Calcagnini, que viu pela primeira vez em casa de Ricardo Pole, onde o ouviu encantado, a ponto de confessar que "me pareceu ter perdido completamente a língua" (VI, ep. 1578, mai. 1525). Era nesta base que assentava a sua noção - e prática - da amizade como factor essencial da solidariedade entre os homens de cultura que ele, por metonímia, gostava de fazer expoentes da comunidade universal dos cristáos; portanto, e em consequência, do mosteiro ideal.

Ora as anotaçóes em cima reportadas sobre Roma são, de facto, excepcionais na correspondência; ressoam, é certo, ao género do encómio de cidade (além de que eram movidas por intençóes aduladoras), mas é indubitável que transportam consigo uma sinceridade sem disfarce. Basta confrontar com o único panegírico que escreveu sobre uma cidade, o poema em trinta e oito versos elegíacos em louvor de Schlettstadt (The Poems, 1956); obedecendo a uma estratégia do discurso muito diferente da usada nas cartas familiares, confina-se aos tópicos habituais: realça a fertilidade da terra, os vinhedos nos montes, o Reno abundante, que corre suave aos ouvidos, os homens ilustres da cidade, como Beato Renano, insistindo portanto nos aspectos positivos próprios do género laudatório. Nada de negativo: a verdade é que nunca viveu nessa cidade do Reno...

Não são deste tipo as referências de teor realista que deixou sobre as cidades onde viveu. Trata-se de anotaçóes que nos mostram a acuidade da sua observação crítica. Mas, e isto é um ponto importante, 
elas não surgem motivadas por um qualquer interesse de viajante observador que busca transmitir aos leitores aspectos interessantes relativos a locais que eles dificilmente poderiam conhecer, mas antes geradas por um factor poderoso em Erasmo: a sua saúde, a sua pessoa. Na verdade, que haveria ele de referir de curioso aos seus correspondentes sobre cidades que eles mesmos também conheciam? Mais importante seria informar sobre o seu estado de saúde, sobre as condições materiais da sua vida, sobre as suas opiniôes, enfatizando essa figura de cristão que suporta estóica e piedosamente os sofrimentos físicos.

É sobre Basileia e Friburgo que as cartas nos fornecem dados mais realistas e mais copiosos sobre a maneira como Erasmo se relacionava com o meio urbano.

Uma carta de 1526, percorrida pela ironia em que Erasmo se mostrava por vezes um mestre, oferece-nos uma cena citadina única na correspondência. Não se trata, porém, de nada parecido com o Ibam forte via Sacra, sicut meus est mos, I nescio quid meditans da abertura do Sermo I.IX horaciano: nunca se mostra como frequentador das praças ou das ruas. A cena descrita reporta-se a um acontecimento ocorrido em Basileia em setembro desse ano, quando se deu a explosão do paiol da cidade. Junto havia um jardim que Froben havia comprado a conselho de Erasmo e onde este costumava passar algumas horas depois do almoço, lutando contra a sonolência que o assaltava ou aliviando o enfado dos seus longos trabalhos. Conta ele que, após 
ter caminhado um pouco, subiu para um pavilhão rústico que aí havia e pôs-se a traduzir alguns "passos do meu Crisóstomo, quando um clarão começou a ver-se pelos vidros das janelas;" quando viu o clarão, julgou tratar-se de uma ilusão visual - é de anotar este espírito analítico e crítico de Erasmo que o levava a desconfiar de milagres e prodígios -, acompanhado de um barulho ensurdecedor. Lembrou-se entáo de um bombardeamento a que assistira em Florença, na época em que o papa Júlio, "esse Júpiter terrestre troava e fulminava contra Bolonha" [1506]: certo dia, quando se "tinha retirado para aliviar os intestinos", deu-se um rebentamento enorme que provocou mortes e feridos, como agora, em Basileia. Erasmo evoca a azáfama dos homens a correrem para o local; nesses momentos tornava-se perigoso alguém atravessar-se na sua frente. Podemos facilmente imaginar Erasmo a regressar apressado a casa, tentando passar através de uma multidão espavorida em armas (VI, ep. 1756, set. 1526).

Mas é a propósito de Friburgo que podemos encontrar, nas cartas, anotaçóes de natureza mais realista sobre aspectos da vida urbana. Como se referiu mais em cima, de início manifesta algum agrado pela cidade que o acolhia quando se vê obrigado a sair de Basileia; mas cedo começa a dar sinais de insatisfação e a confessar que estava ansioso de ir para outro lugar. Tinha-se mudado no verão de 1529 e já no outubro seguinte escrevia que, uma vez passado o inverno, pensava ir "no tempo da andorinha para onde Deus me chamar" (VIII, ep. 
2222). E um ano depois escrevia que "desde há bastante tempo que morro por partir daqui e ir para outro lugar" (VIII, ep. 2355, jul. 1530). Afinal porquê?

Numa carta ao já referido Erasmo Schets, em março de 1532, quando a saúde não melhora e o obriga a resguardar-se cada vez mais contra os ambientes exteriores, escreve que não pode aceitar as insistências da rainha Maria, viúva de Luís da Hungria, para que regressasse ao Brabante (teria ela força para o defender da fúria dos frades?), porque o seu pobre corpo - aos cinquenta anos começa a ser tópico obsessivo nas cartas, com metáforas do tipo o "meu pobre envelope corporal", (V, ep. 1267, mar. 1522); "a minha miserável carcaça” (V, ep. 1408, jan. 1424) - não suportaria esse clima frio e ventoso; em Friburgo a custo procura preservar a sua vida escondendo-se no seu quarto (IX, ep. 2620). Mas a cidade vai-se revelando cada vez menos suportável, agora também por razóes de higiene. Em janeiro de 1534, escrevendo a Gaspar Schets, filho mais velho de Erasmo e como o pai também seu agente financeiro em Antuérpia, queixa-se da falta de limpeza das mulheres de Friburgo; isto por causa de uma criada que lhe teria arruinado a casa se náo tivesse acordado a tempo para os roubos da rapariga (nomeadamente, esvaziava-lhe os barris de vinho...); por isso, resolveu reconciliar-se com a antiga criada de há dez anos, que havia afastado, mas de quem só se livrará em 1535, quando voltar outra vez para Basileia (X, ep. 2897, jan. 1534).

Veja-se o panorama descrito no final da carta, que é um autêntico único: 
"Reina aqui [em Friburgo] uma enorme porcaria. Ao longo de todas as ruas desta cidade desce um riacho artificial, que recolhe a porcaria vinda dos açougues e do mercado, os lixos de todas as cozinhas, as imundícies e as urinas das casas particulares e até os excrementos dos que não têm latrinas em casa. É com esta água que se lava a roupa branca, com que se limpam os jarros / cântaros do vinho e até os utensílios de cozinha. Mas tudo isso se poderia suportar se houvesse alguma coisa para comer. Durante todo o ano como galinha; aqui não há comidas refinadas ou, se há, ficam para os abastados."

É este um passo excepcional na correspondência, não só por causa do realismo objectivo (predomina a função informativa, sem elaboração retórica), mas também porque ele evidencia de forma clara que o registo discursivo sobre a realidade urbana não decorre propriamente de uma estratégia de observação praticada em relação ao local, mas antes dos efeitos directos sobre a sua pessoa, a sua saúde, o seu bem estar... A verdade é que a realidade das ruas de Friburgo não lhe era desconhecida, porque era esse o ambiente da higiene em qualquer cidade europeia de então; e Erasmo conheceu várias. A acrimónia que se pressente nestas palavras tem a ver com a impossibilidade de usufruir dos mimos a que julgava ter direito e que o seu pobre corpo e a sua saúde exigiam. Juntando a isto o relativo isolamento de uma cidade algo afastada das vias de comunicação mais intensas, percebemos porque é que repete esse desejo de deixar a cidade. É o tempo em que evoca por vezes 
a Holanda, temendo, porém, regressar a ela: "Há dez dias que uma tortura abominável invadiu a parte direita da cabeça e do pescoço, o ombro e o braço", parecendo querer instalar-se de vez; "se fossem só quatro dias de viagem para chegar ao Brabante, trataria de me fazer transportar, ainda que fosse de liteira, de tal forma estou cheio desta terra” (X, ep. 2924, abr. 1534).

O lugar onde se sente melhor é cada vez mais a casa; as metáforas do ninho, do voo e da andorinha na primavera ocorrem envolvidas de certa sentimentalidade que denota a fragilidade crescente em que se encontra. Em reforço desta faceta anotadora da realidade comandada pelo critério da sua reacção física aos ambientes, vale a pena evocar as observaçóes que também fez sobre as casas inglesas.

De Inglaterra guardava lembranças agradáveis, mas à sua capacidade de observação crítica não escapavam aspectos menos recomendáveis dos hábitos das pessoas. Sobretudo, aquilo que mais o impressiona, porque o incomoda, é o clima; sempre o mesmo padrão de base para apreciar o lugar onde habita. O clima inglês é apreciado negativamente: "uma insalubridade persistente, principalmente uma humidade mortal", decorrente da maneira como as casas estavam construídas. Não se tratava, porém, de conclusão nascida exclusivamente da observação experimental das coisas, mas também de um saber letrado, porque se fundamenta em autoridades antigas. Como escrevia ao médico inglês John Francis, a solução seria rever a má orientação das portas e janelas das casas, a falta de 
exposição ao ar. Os compartimentos deviam ter dois ou três lados abertos à luz do dia, as janelas deviam abrir-se e fechar-se por completo, evitando-se as frinchas largas por onde passavam os ventos nocivos - era uma ideia corrente na época que o vento era portador de doenças -. Tudo preceitos de Plutarco e de Galeno. É por aí que anota a quantidade de pântanos e ribeiros salgados por efeito das salmouras e que acha que o país seria muito mais salubre se o chão não fosse

"coberto de argila ou de juncos, que não se renovavam durante muitos anos, cobrindo-se de escarros, de vómitos, de urinas de cães e de homens, de cerveja entornada, de restos de peixe e outras muitas porcarias; de tudo isso emanava uma exalação pouco salubre, penso eu, para o corpo humano."

Mas o mais importante seria fazer com que

"as pessoas fossem mais comedidas na alimentação e sobretudo se moderassem nas salmouras e se oficiais públicos fossem encarregados de limpar as ruas da porcaria e da urina (V, ep. 1532, c. dez 1524).”

Anotar-se-á o recurso ao detalhe descritivo, que ajuda a suportar a sua opinião, numa matéria que o tocava de forma particular como eram as questóes de saúde. No fim da carta pergunta: porquê estes detalhes?

"É que eu tenho simpatia por um país que durante tanto tempo me ofereceu hospitalidade e onde eu terminaria de boa vontade o tempo que me resta de vida, se pudesse." 
Ainda viveria mais doze anos... Simples nota de boa educação diante de este médico inglês? Pode ser; mas anotemos como náo saímos do ponto de vista fundamental: Erasmo regista as suas anotaçôes sobre aspectos concretos da vida social, sobretudo citadina, não na perspectiva de um informador objectivo daquilo que observa, mas a partir da sua própria pessoa.

A casa de Erasmo fica na cidade; e Erasmo em casa é também Erasmo na cidade; é aí que trabalha incansavelmente, qual abelha laboriosa (Margolin, 1993):

"há mais de vinte anos que tenho o hábito de escrever de pé e de nunca me sentar, por assim dizer, senáo para almoçar e jantar, ou para fazer a sesta depois do almoço, coisa que faço de vez em quando, sobretudo quando estou cansado. Mas já me tem acontecido que, por causa dos trabalhos de impressão [ou seja, de revisão dos textos em fase de impressão] e em especial pela enorme quantidade de cartas que tenho de escrever, de correr para o escritório mal acabo de almoçar" (VI, ep. 1759, out. 1526?).

A casa é o seu mundo; trata de proteger o melhor possível esse ninho dos incómodos citadinos (os maus cheiros, a porcaria, a vagabundagem) - a metáfora do ninho surge nas cartas do período de Friburgo, marcado pelas saudades de Basileia (VIII, ep. 2162, mai. 1529), como por exemplo "agora, em pleno inverno, não é prudente voar para fora do ninho", (IX, ep. 2397, out. 1530); "tenho de passar o inverno neste ninho" (IX, ep. 
2565, nov. 1531) -, como conta a Rinck em carta de setembro de 1531 (IX, ep. 2534):

"Viajo ainda ao estrangeiro na minha própria casa porque, ainda que espaçosa, não tem nenhum canto a que possa confiar o meu pobre corpo com segurança.”

É curioso que nunca coloca a hipótese de se refugiar no campo... Mas se o quarto é cada vez mais o seu mundo, não chega a imaginar uma viagem no seu interior, como Xavier de Maistre com a Voyage autour de ma chambre - ele que nem sequer teve a ousadia de ir até ao quintal porque, no dito de Almeida Garrett, não teve este clima, este ar que Deus nos deu para viajar na nossa terra -. Só por um exercício de imaginaçáo podemos vê-lo naquela posição que o autor francês do séc. XVIII entendia a melhor para reflectir (cap. XXXIII), ou seja sentado numa cadeira de braços, com as pernas estendidas por cima do fogão. Ora Erasmo, que abominava os fogóes colectivos, acesos durante a maior parte do ano na generalidade das casas e estalagens na Alemanha, mandara fazer um, grande, para si, em sua casa.

Tudo isto, porém, nada tem a ver com a sensibilidade diante da paisagem que se vế; a estética é coisa do séc. XVIII. Seria, por exemplo, impossível procurar alguma anotação sobre a Holanda - para ele é uma terra com um clima horrível - que fizesse lembrar a delicada luminosidade holandesa que Marcel Proust evocou na zona final da II parte de "A l'ombre des jeunes filles en 
fleurs", acerca dessas "femmes d'une extrême élégance" envoltas "dans une lumière humide, hollandaise" que vagueavam pela praia, a lembrar algumas das fotografias de Henri Lartigue no início do séc. XX... É óbvio que Erasmo tinha de ser completamente alheio a coisas como estas. A sua sensibilidade era mais afinada para o que dizia respeito à musicalidade, à eufonia e ritmo da frase, como se vê na maneira como aprecia a elegância retórica e abomina tudo o que fosse ruído ou desarmonia (Margolin, 1969). Isso revela-se, por exemplo, nas consideraçóes que tece sobre a complexidade da versificação nas tragédias de Eurípides a propósito da sua tradução da Hécuba e da Ifigénia, um poeta, diz, com uma linguagem mais doce que o mel (I, ep. 188, jan. 1506?), apontando as dificuldades em verter para latim a excessiva variedade e liberdade dos metros dos coros (I, ep. 208, nov. 1507?) (Lourenço, 2008).

As letras, as boas letras, eram, certamente, libertadoras do homem, portanto do cristáo; mas exigiam a cidade e, na cidade, a casa onde viver. 


\section{BibLIOGRAFia}

Opus Epistolarum Des. Erasmi Roterodami, ed. P. S. Allen e H. W. Garrod (1906-1947), 11 vols., Oxford, $(1967-1982)=$ La Correspondance d'Érasme, dir. Aloïs Gerlo e Paul Foriers, 11 vols., Bruxelas.

Desiderius Erasmus Roterodamus (1964), Ausgewählte Werke in Gemeinschaft mit Annemarie Holborn Herausgegeben von Hajo Holborn, Munique.

The Poems of Desiderius Erasmus, ed. C. Reedijk (1956), Leiden.

Bierlaire, Franz (1968), La familia d'Érasme. Contribution à l'histoire de l'humanisme, Paris.

Lourenço, Frederico (2008), Novos ensaios helénicos e alemães, Lisboa.

Chantraines, Georges (1971), «Mystère» et «Philosophie du Christ» selon Erasme, Namur-Gembloux.

Margolin, Jean-Claude (1973), Guerre et paix dans la pensée d'Érasme, Introduction, choix de textes, commentaires et notes, Paris.

_- Jean-Claude (1993), Érasme: une abeille laborieuse, un témoin engagé, Caen.

Halkin, Léon-E. (1969), Erasmo, México.

Mumford, Lewis (1961), The City in History. Its Origins, Its Transformations, and Its Prospects, Nova Iorque. 
Boyle, Marjorie O'Rourke (1977), Erasmus on Language and Method in Theology, Toronto e Buffalo. 


\section{André de REsende e a RELATINIZAÇÃo ortográficA DA LÍngua Portuguesa}

Sebastiāo Tavares de Pinho 
No conhecido movimento de relatinização do português, que teve a sua maior expressão no ambiente renascentista do século XVI, assume incontestável protagonismo o humanista André de Resende, cuja merecida fama não se deve apenas à vasta e variada produção literária escrita em elegante latim, ou por ter sido o inventor da palavra "Lusíadas" e de outro vocabulário épico, como o nome das "Tágides", mas também porque conquistou um justo lugar de relevo entre os principais escritores de língua portuguesa de Quinhentos. ${ }^{1}$

É nessa produção literária em vernáculo que o humanista eborense evidencia a sua declarada propensão para a ortografia latinizante do português, como pretendemos demonstrar com base nos textos de grafia autêntica chegados até nós, a saber:

1 - Carta a D. João de Castro, Lisboa, 16 de Março de 1547 (ANTT, Ms. São Lourenço, IV, fol. 52-53);

2 - Historia da antiguidade da cidade de Evora. Fecta per Meestre Andree de Resende (Évora, 1553 e 1576);

${ }^{1}$ Serafim da Silva Neto emitiu a seu respeito o seguinte juízo: "André de Resende foi exímio e brilhante estilista em língua portuguesa. A sua prosa é das mais vivas e graves do século em que viveu. [...] É serena e corrente, cheia de naturalidade e expressão" (vd. Silva Neto 1947: 84). 
3 - Fala que Meestre Andree de Reesende fez aa Princepsa Domna Ioanna [...] na entrada da ciidade de Evora (incluída na obra anterior deste elenco, fols. $\mathrm{f}$ vij-viij da edição de 1553, e fol. f vj-vij vo da de 1576);

4 - Sermam que pregou ho doctor meestre Andree de Resende [...] en o synodo [...] de Evora [...] ho primeiro domingo do mes de Feuereiro MD LXV (Lisboa, 1565);

5 - Fala que Meestre Andree de Reesende fez a el rey Dom Sebastiam a primeyra vez que entrou en Euora (incluída na obra do no 2 desta lista, Évora, 1576, fols. f viij - $\mathrm{g} \mathrm{v}^{\mathrm{o}}$ );

6 - Ha sancta vida e religiosa conuersaçam de Frey Pedro [...] Scripta per ho doctor Meestre Andree de Reesende (Évora, 1570);

7 - Testamento de André de Resende (Dezembro de 1573).

Todas estas obras foram publicadas pelo autor, com excepçáo evidentemente do seu testamento. Mas, deste, existe publicação póstuma a partir do original, que respeita a primitiva ortografia, conforme esclarece o seu editor (Leitão Ferreira 1916: 130-131) e como podemos comprovar pelo confronto com o sistema ortográfico das restantes obras supracitadas.

Por outro lado, conservou-se o autógrafo da Carta a D. João de Castro, cuja primeira página aqui reproduzo no Anexo I.

Existe também um manuscrito autógrafo do pequeno discurso (da "Fala" que ocupa o terceiro lugar da lista anterior, cuja página inicial vai igualmente 
aqui reproduzida no Anexo II) pronunciado por Resende em finais de Novembro de 1552 e publicado em apêndice à História da cidade de Évora saída a lume em 26 de Outubro de 1553 e em edição póstuma de 1 de Fevereiro de 1576, feita sobre um texto ainda emendado pelo autor, conforme se declara na sua portada: "E agora nesta segunda impressam emendada pelo mesmo autor".

Fica fora deste elenco de pesquisa a Vida do Infante Dom Duarte, escrita em 1567, mas publicada pela primeira vez apenas em 1789, por ordem da Academia das Ciências de Lisboa; em 1842, pela Revista Literária (Porto, vol. IX); e em 1963, nas Obras Portuguesas de Resende, organizadas por José Pereira Tavares. A ortografia, em todas estas ediçóes, foi modernizada e claramente não respeitou a escrita do texto autógrafo, entretanto desaparecido. Por isso não serve aos objectivos deste estudo.

Vejamos o testemunho dos próprios textos resendianos e comecemos por transcrever alguns extractos da primeira Fala, isto é, da pequena oração de entrada pronunciada em finais de Novembro de 1552 perante a princesa Joana de Áustria, filha de Carlos V, aquando da sua entrada em Portugal como noiva do príncipe D. João, filho de D. João III, e no momento em que ela passava pela cidade de Évora. O humanista André de Resende, um dos oradores mais conceituados da época, assume a missão de lhe dar as boas-vindas em nome da capital alentejana e do seu povo, num discurso breve que contém todos os ingredientes oratórios do protesto de 
modéstia pessoal e da exaltação da destinatária, numa grafia sobrecarregada de formas latinizantes ${ }^{2}$ :

Princepsa exclarescida, Princepsa de nos tãto desejada. Se ho immenso \& excessiuo plazer que hoje en nos triumpha, per palauras se podesse explicar, mui pouco seria, ho que hos poetas en has cousas arduas \& difficiles costumauan, desejar cent boccas, \& cent linguas, \& hũa voz aceira $\&$ incansauel. Qua non è tam leue nem tá mediocre ho alegre mouimento de tâtos coraçóes, que per tam poucos instrumentos assi facilmente se lexasse declarar. Mas ja que desta parte ha impossibilidade nos tẽe desengannado, \& de outra, nó padesce ha qualidade do tempo que com longa oraçã detenha V. A. \& impida esta commun alegria, \& acceso desejo de vos veer que nem pode tẽer silencio, nem soffre dilaçam: reduzindo me a ho que breuissima \& summariamente non consente ha razam que lexe de dizer. Princepsa serenissima, esta vossa cijdade [...] en sua origẽe \& fundaçam antiquissima, en ha fee catholica \& religiã christâa entre todas has de Hispania ou mais antigua, ou táto quanto ha que mais, en nobleza de estes regnos ha segunda, \& en lealdade, amor \& seruiço da real coróa delles sen duuida ha primeira, beisa vossas reaes mãos, \& per hũo publico \& gẽeral voto, com os animos chẽos de tanto contentamento, de quanto ho humano intellecto é capaz, pede a d's omnipotente que vossa vinda a estes regnos seja felicissima. Entrae senhora per hos muros dos vossos, $\&$ appousentae vos entre hos vossos, quomo lhes ja entrastes

2 Servimo-nos do texto impresso, que apresenta algumas pequenas variantes da responsabilidade do autor relativamente ao seu manuscrito autógrafo, ainda existente, que ele reviu e aperfeiçoou para efeitos de publicação. Acerca da prioridade de um sobre o outro, vd. Pinho, 2006: 232-238. 
per hos coraçóes, que logo ficaron entreghes [...] (Vd. Fala à Princesa, 1553: fol. vij-vij vo; e fol. viij).

Os vocábulos em itálico apresentam na sua maioria grafias que, por uma ou outra razão, indiciam uma clara preocupação etimológica latina. É o caso da palavra 'Princepsa', que, independentemente da proveniência da sua importação (francesa? ou castelhana?), póe à evidência a forma etimológica latina "princeps" assente no próprio nominativo mediante a simples adjunção do sufixo indicativo do feminino e sem permitir a assimilação da oclusiva -p- por parte da sibilante -s-. É um artifício, ao que parece, da responsabilidade de Resende, mas representa sem dúvida uma motivação etimológica. Isto acontece por quatro vezes nesta "Fala", e vamos encontrá-lo também na Vida de Frei Pedro (fol. a ij - ij vo).

A grafia do vocábulo 'exclarescida" mostra-nos a dupla curiosidade de apresentar, por um lado, o prefixo latino ex-, que deu origem à correspondente forma vernácula es- presente em grande número de vocábulos portugueses desde a Idade Média, e, por outro, o conjunto incoativo -sc-, igualmente herdado do latim, que entrou na formação de verbos de tema em $e$ (-scer), dos quais a maior parte perdeu, desde longa data, o -s-do referido conjunto (dos cerca de 280 verbos dessa formação, apenas perto de 50 conservam hoje a terminação -scer). Resende optou por esta grafia em mais de duas dezenas de formas verbais e mesmo de nomes delas derivados. Só na Vida de Frei Pedro encontramos 
mais de cinquenta passos com os seguintes exemplos: accontescer, admanhescer, cognoscer/cognoscidas, desaparescer, desfallescer / fallescer / fallescido / fallescimento, exvãescer, favorescer, merescer, offerescer, padescer, parescer (mais de vinte cinco vezes), pretenscer, resplandescer.

Outra opção da ortografia resendiana respeita ao uso persistente de consoantes geminadas, de tradição latina, como se vê pelos exemplos colhidos neste texto: o adjectivo 'immenso', que decalca o particípio latino immensus; 'bocca', que assenta directamente no latim bucca, mas que já havia reduzido a geminada na sua forma vernácula do séc. XI, e que o humanista agora adopta; 'desengannado', baseado no latim vulgar ingannare, a partir do latim clássico gannire, (latir, ganir; chilrear, grunhir; cochichar; caramunhar); 'commum', do latim communis; 'acceso', refeito a partir do latim accensus, particípio do verbo accendere, cuja forma portuguesa já havia reduzido a geminada pelo menos no séc. XIV, em que aparecem grafias como 'acesso' e 'acezo'; o advérbio 'summariamente', assente na raiz do substantivo latino summa, que já aparece pelo menos desde os finais do séc. XIV mas com o -m- radical reduzido e cuja geminação ressurge no século de Resende. Bem como as geminadas do vocábulo 'soffre', recebido do verbo latino sufferre $(<$ sub+ferre $)$ através da forma deduzida * sufferere; do substantivo 'intellecto' (do latim intellectus), assumido na língua portuguesa provavelmente antes do séc. XVI, mas que na época de André de Resende já se apresentava correntemente sem geminada, em grafias como 'inteleito' 
ou a moderma 'intelecto'; o imperativo 'appousentae', já detectável desde o séc. XIII sem geminação (apousentar, apoussentar e aposentar) e que Resende grafa com a geminada -pp- em consonância com a etimologia latina $a d+$ pausa, que deu origem a todo o léxico da mesma raiz; e, enfim, a própria formação aglutinada 'delles', que o humanista relaciona naturalmente com o pronome latino ille.

Um caso de latinismo não apenas gráfico mas também morfológico é o do adjectivo 'difficiles', plural modelado na morfologia do correspondente latino difficiles, que passou a ser usado em língua portuguesa no tempo de André de Resende por ele e por outros humanistas amantes da ortografia latinizante. Inclui-se neste caso 'viles', plural de 'vil', e 'horribiles', também usados na Vida de Frei Pedro (fol. a iij vo: "hos officios mais baixos, \& viles"; fol. b: "offerescendolhe visôes horribiles"). À mesma série morfológica pertence, ainda, 'immobile' (ib., fol. a viij). ${ }^{3}$

Em matéria de uso de nasais, como se vê no texto acima transcrito, o antiquário eborense mais uma vez se aproxima da etimologia latina em vocábulos como o advérbio 'non', usado sistematicamente em toda sua obra quer nesta grafia plena que transcreve o latim non, quer na escrita nasalizada 'nô' que se pode presumir corresponder à pronúncia de ambos. $\mathrm{O}$ mesmo se pode

${ }^{3}$ Serafim da Silva Neto cita, a este propósito, mais uma dezena de plurais deste tipo em outros tantos autores contemporâneos de André de Resende, em obras publicadas entre 1553 e 1594 (Silva Neto, 1947: 106). 
dizer do advérbio 'tam', habitualmente escrito à maneira latina; e, ainda, acerca da preposição 'en', em vez de 'em' por ser graficamente mais próxima da original latina in, o que acontece igualmente com a preposiçáo 'sen', que surge em toda a obra portuguesa de Resende e cuja grafia aponta, mais directamente do que a sua alternante 'sem', para a fonte latina sine. Também latinizante parece ser a grafia do vocábulo 'costumauan' na sua terminação em - $n$, que alterna frequentemente com -m e que, em termos gráficos, corresponde melhor do que esta à desinência latina $-n t$ da $3^{\text {a }}$ pessoa do plural das formas verbais.

Um caso de grafia latinizante que envolve elemento nasal e vogais geminadas está também documentado em vários exemplos do extracto acima transcrito. Assim, o substantivo 'corôa' retoma a forma arcaica em que a consoante - $\mathrm{n}$ - do original latino corona conserva os seus vestígios sob a forma de nasalização da vogal antecedente. $\mathrm{O}$ mesmo fenómeno se verifica em 'christáa', derivado do latim christiana; em 'chẽos', proveniente do adjectivo latino plenus; em 'gẽeral', 'origẽe', 'tẽer' e 'tẽe', evoluídos a partir das respectivas formas latinas general (em), origine $(\mathrm{m})$, tenere e tenet.

Fenómeno paralelo a este é o da presença de vogais geminadas que denunciam a consoante latina intervocálica que, por ter esse carácter, ou em associação com ele, teve tendência a sincopar-se na evolução do latim para o português. É o caso dos vocábulos 'veer', 'fee' e 'cijdade', que derivam das respectivas formas latinas uidere, fide $(m)$ e ciuitate $(m)$ e estão bem mais 
próximos da sua matriz histórica, do que nas formas ulteriores reduzidas 'ver', 'fé' e 'cidade', que já existiam no tempo de Resende, mas que ele preteriu em favor da grafia etimológica e latinizante.

No mesmo sentido merece reparo a grafia das formas verbais 'lexe' e 'lexasse', em vez de 'leixe' e 'leixasse' na sua forma vocalizada, já existente desde o séc. XI. Resende optou pela grafia anterior por ela registar um estádio de evolução mais próximo da etimologia do verbo latino laxare; e, como este, também o caso de 'beisa', do verbo 'beisar', em vez de 'beijar' já existente pelo menos desde o séc. XIII, cuja sibilante -s-, em vez de -j-, a coloca foneticamente mais próxima do étimo latino basiare.

Como claro latinismo, pelo menos gráfico, deverá ser considerada a grafia de 'regno' bem como outros daí derivados existentes na mesma "Fala" a que pertence o texto acima transcrito e nas restantes obras resendianas em vernáculo, como nos vocábulos 'regnare' e "regnado", baseados na raiz latina de regnum, em substituição da grafia com a consoante -g- vocalizada ('reyno' ou 'reino'), que já existiam desde o séc. XIII.

No âmbito das consoantes devemos ainda mencionar os dois casos das palavras 'nobleza' e 'plazer', preferidas pelo nosso humanista às formas 'nobreza' e 'prazer', embora antigas, por aquelas manterem a sua raiz mais próxima dos respectivos étimos latinos, a saber, o radical de nobilitas e de placere. E o mesmo se passa com o numeral 'cent', em que Resende retoma a raiz latina de centum, apesar de existirem as formas 
medievais 'çien', 'cem' e outras.

No que respeita ao uso da aspirada h, excluindo os casos da sua presença sistemática na grafia dos artigos definido e indefinido ho, ha, hos, has, e hũo, hũa, que são de tradição antiga e, como se sabe, nada têm que ver com questóes de etimologia, três casos há - 'triumpha', 'catholica' e 'christãa' - em que a sua manutenção aponta evidentemente para a origem latina no primeiro caso e greco-latina nos outros dois.

De notar, ainda, o conjuntivo 'impida', forma arcaica que o autor prefere por conservar mais intacto o radical latino do verbo impedire; bem como o uso da preposição 'per', na sua forma também arcaica e autónoma, isto é, sem se aglutinar nem sequer ao artigo definido ("per hos muros", "per hos coraçôes"), e igualmente preferida por transcrever a exacta forma da sua origem latina.

Quanto ao topónimo 'Hispania', sendo forma assumidamente portuguesa, não deixa de ser um latinismo que aqui designa toda a Península Ibérica. Recordemos que o mesmo André de Resende, em carta de 4 de Maio de 1567, de resposta ao toledano Bartolomeu de Quevedo, lhe lembrava que portugueses e espanhóis eram todos hispanos: "Hispani omnes sumus" (Pereira 1988: 130-131).

Finalmente, para terminar a análise da ortografia latinizante do extracto da "Fala à Princesa Dona Joana", resta-nos referir os vocábulos 'antigua', 'qua' e 'quomo', formas arcaicas de 'antiga', 'ca' e 'como' e cuja grafia mantém o apêndice bilabial -u- da sua etimologia 
latina, que os liga graficamente à sua forma original, respectivamente antiqua, quia e quomodo.

Esta mesma preocupação etimológica mantém-se e abrange muito outro vocabulário na Vida de Frei Pedro como vamos verificar em alguns extractos do seu texto. O primeiro é colhido do início do Proémio, em que frei André de Resende, aos sessenta e cinco anos de vida, recorda seus tempos de noviço do Mosteiro de Sáo Domingos de Évora, onde pôde conhecer de perto as virtudes do porteiro frei Pedro, e explica como assumiu a missão de escrever a sua biografia:

Per algũos padres da ordẽe, persõas religiosas \& doctas, fui per vezes requerido que screnesse ho que sei da virtude $\&$ sanctidade de Frey Pedro porteiro do móesteiro de Sanct Domingos de Euora. Porque, quomo eu en haqlla casa me criey, alcansey tẽer delle hũa particular familiaridade, \& com ipso muita experientia de suas cousas. Prometti de ho fazer, mas dilatey ho muito tempo. [...] Se de este mundo partijsse sen me desobligar de esta diuida, per ventura, \& sen per ventura, tãbẽe me nó desobligaria de dar côpta a d's, por escóder has mercees de q̃ a elle aprouue fazer me participante, \& quiça por ipso hacte ho presente me dar vida, para has publicar. Quero pois cố seu fauor \& adjuda, pagarlhe este deuido tributo [...] (Vd. Vida de Frei Pedro, fol. a iij).

Alguns dos vocábulos aqui destacados estão incluídos no texto anterior e foram objecto do respectivo comentário, por isso trataremos aqui apenas dos restantes.

O adjectivo indefinido 'algũos', com a vogal 
-o- distintiva do masculino, evoca mais de perto a sua formação latina [aliqu(is)+unu(s) > alicunu $>$ aliguno $>$ alguno], do que as formas mais "corruptas" como 'algun/alguns' já existentes no séc. XIII, e constitui, por isso, uma retoma latinizante.

Na palavra 'persóas', Resende prefere e sistematiza a grafia que mantém a líquida -r-do original latino persona, outrora assimilada pela sibilante sequente, e assinala a presença da nasal -n- na forma do til sobre a vogal que a antecede, para efeitos pelo menos da sua nasalização.

Sobre o vocábulo 'doctas', importa lembrar que, embora Duarte Nunes de Leão tenha admitido na Regra II da sua Ortografia, seis anos depois da publicação desta biografia resendiana de Frei Pedro, que a consoante -c- se pronunciava na palavra 'docto' e em outras suas cognatas como 'doctor' e 'doctrina', também presentes nas restantes obras de Resende, em alternância com a grafia da consoante vocalizada 'douto', etc. (LEÂO 1983: 134-135), a verdade é que elas não deixam de ser latinismos.

A mesma consoante da raiz latina é mantida em 'sanctidade' (tal como em 'sancto', 'sancta', 'sanctissima', que aparecem em outros textos resendianos) e na curiosa grafia de 'Sanct' Domingos, que o humanista repete, aproximando-a da forma latina Sanctus até ao limite, isto é, sempre que o nome do santo começa por consoante, por exemplo em 'Sanct' Joanninho, 'Sanct' Paulo, 'Sanct' Mancio e 'Sanct' Pedro, em substituição e paralelismo com a forma portuguesa 'Sam' ou 'São' 
usada em igual circunstância. Isto parece demonstrar que tal grafia não passava de puro grafismo etimológico que nada interferia com a pronúncia de 'Sam' ou 'São', como aliás acontecia muito provavelmente na maior parte dos demais latinismos.

O vocábulo 'screuesse', com ausência do eprotético que, já a partir do latim vulgar, se gerou em palavras começadas pela sibilante s- seguida de uma ou duas consoantes, é mais uma das preferências sistemáticas do programa de relatinização ortográfica de André de Resende, como se vê em muitos outros casos como: scripto e scriptura, scada e scala, scandalizar, scapulario, scasso, scrupulo, scudella, spaço, spelho, sperar, spirito, spiritual, squeecimento, squivo, staca, star (com abundantes exemplos da sua variada morfologia), stilo, stimular, strado, strella, strellado, studioso.

As palavras 'mõesteiro' e 'mercees' são mais dois exemplos de arcaísmos latinizantes, o primeiro porque mantém no til o que resta da nasal-n-de monasterium, e o segundo pela presença da vogal geminada denunciadora da consoante intervocálica original do latim mercedes, entretanto sincopada.

Também testemunha a sua origem latina a palavra 'desobligar' com a líquida originária -1- , como já vimos acima em 'nobleza' e 'plazer', e como acontece com outros casos da obra de Resende, designadamente em 'blando', 'noble' e 'regla'. E o mesmo se diga das formas 'prometti' com sua geminada latina; 'cópta' com o radical latino incorrupto herdado de computare; e muito claramente a grafia de 'experientia', que, à semelhança de outras 
terminadas em -entia, em vez de -ência, ('negligentia', 'patientia') transcrevem simplesmente o latim.

Caso curioso de latinismo gráfico é o pronome 'ipso', como também as formas masculina 'epse' e feminina 'epsa', que resultam do latim ipse, ipsa, ipsum, e percorrem sistematicamente os textos portugueses de Mestre André, constituindo o que se me afigura uma raridade ortográfica.

A forma 'hacte', grafia resendiana da preposição e advérbio 'até', tem dividido os etimologistas entre propostas diferentes, uma árabe (hattā), outra latina ( $a d$ tenus). Não será que André de Resende, ao escrevê-la com aspirada inicial, não teria no pensamento uma outra hipótese, ainda que eventualmente errada, nada menos que o advérbio latino hactenus, que tem valor semântico muito semelhante?

O demonstrativo 'haquella', bem como os cognatos 'haquelle', 'haquillo', muito recorrentes em todos os textos de Resende, mantêm a geminada da sua origem latina (eccu+illa, eccu+ille, eccu+illud); e quanto à aspirada inicial, também aqui o humanista poderia ter feito associação com os pronomes demonstrativos latinos hic, haec, hoc. Não é de estranhar tal hipótese, numa época em que os estudos filológicos não dispunham das conquistas e dos meios que a ciência moderna possui.

Passo a transcrever um último trecho da Vida de Frei Pedro para confirmar alguns casos já comentados e sobretudo para apreciar algumas situaçóes de particular interesse quanto ao método com que o humanista conseguia, por vezes com um mínimo toque de 
ortografia, revestir certos vocábulos de uma roupagem latina. No seguinte extracto, Resende refere as qualidades de Frei Pedro como antigo grumete da marinha, onde este aprendera alguns rudimentos de navegação e do necessário conhecimento da astronomia:

Eu vij star frey Pedro arrimado a hũa columna do claustro, com os oclhos para ho ceo, que staua muy sereno \& strellado, \& chegando me a elle quomo familiar, lhe perguntey que oclhana. Respondeo me. Haa muito tempo que de nocte, per este certo poncto attento para ho norte, per cima da cabeça de haquelle acypreste, \& tenho notado ser falso ho que algũos dizem, que ha strella do Norte é ho polo, \& que non se moue (vd. Vida de Frei Pedro, fol. a viij).

Deste trecho são de notar a grafia de 'vij' com a dupla vogal a evocar a mesma $1^{\text {a }}$ pessoa do singular do pretérito perfeito latino vidi, em que o -d-intervocálico veio a cair durante a evoluçáo para vernáculo; a de 'columna', homógrafa da própria forma latina; as de 'nocte' e 'poncto' com manutenção da consoante -clatina; e os vários casos de consoantes geminadas. Em 'strella' e 'strellado' verifica-se exemplo de contaminação ortográfica das raízes latinas de stella e astrum. Mas o mais curioso deste trecho é a grafia do substantivo 'oclho' e respectiva forma verbal 'oclhaua' (e outras, como 'oreclha'), em que, pela reinclusão da simples consoante -c- da raiz latina de oculus dentro do radical vernáculo 'olh-' dela derivado, e por uma espécie de hipergrafismo ou pleonasmo gráfico, o autor concedeu ao produto assim conseguido um visual mais latinizante. 
O sistema ortográfico de André de Resende foi assumido desde jovem e conservado durante a vida inteira, como se vê pelos primeiros trechos em português que dele nos restam, datados de 1535, a saber, dois registos de baptismo que ele ministrou em Évora nos quais já aparecem os mesmos critérios de escrita, incluindo formas latinizadas como 'baptizei', 'assignei' 'octubro' e expressóes como 'ho doctor' e 'assignei aos dias \& era sobredictos'. E assim persistiu até à beira da morte, ocorrida em Dezembro de 1573, segundo se pode ver no texto do seu Testamento, cuja primeira parte ele ainda redigiu por seu punho e de cujo original restam reproduçóes com fidelidade ortográfica garantida pelos editores. Vejamos um extracto do seu início, onde facilmente se detectam, vários dos latinismos já acima comentados e se comprova a constância caligráfica do Mestre André de Resende:

Em nome da Sanctissima Trindade Padre, e Filho, et Spirito Sancto, tres hypostases, ou pessoas, hũa essencia, hũo Deos, non tres Deoses, cuja fee eu indigno sacerdote sempre tive, tenho, e terei quomo catholico filho da Sancta, et universal Egreja Romana, et en nome da perpetua, et nunqua violada Virgen Sancta Maria [...].

In primis declaro que eu me criei no habito et ordẽe de Sanct Domingos, no móesteiro desta cijdade, et nelle fiz profissam, et trouxe ho habito passante trijnta annos, hacte que frei Hieronymo Padilla mo fez tirar, por eu ser exempto, et star en seruiço del Rei, et de seus hirmãos teendo elle para ipso hũo breve da Sancta Sede apostolica quomo constaraa per hũo instromento que sobre ipso tirei, fecto per Philippe Diaz notario [...] (Leitão Ferreira 1916: 130-131). 
A maior parte das formas aqui sublinhadas já foram objecto de comentário, mas não deixarei de notar as grafias greco-latinizantes de 'hypostases', 'Philippe' e 'Hieronymo', bem como a presença da nasal final -n em 'Virgen', que pode ser motivada pela mesma na radical da forma latina uirgin [de uirgo, uirgin(is)]. Por outro lado, 'exempto' e 'fecto' conservam as marcas latinas nas respectivas consoantes $-\mathrm{p}-\mathrm{e}-\mathrm{c}-$, como acontece com numerosas formas cognatas de um e outro, principalmente do segundo. A grafia de 'nunqua' reflecte a latina nunquam, e a geminada de 'trijnta' adverte para a queda da consoante intervocálica do mesmo numeral latino triginta. De resto, em matéria de numerais, Resende usa sistematicamente formas latinizadas como 'cinquo', 'sex' e 'sexcentos', 'septe', 'octo', 'dezocto', 'cent'.

Um texto de capital importância para o estudo da prática ortográfica de Resende é a Carta que ele escreveu em 16 de Março de 1547 a D. Joáo de Castro, dois anos após a passagem deste por Évora na Primavera de 1545 a despedir-se do rei e a preparar a sua partida para o Oriente na qualidade de governador da Índia, recentemente nomeado.

Resende, que "a epse tempo staua en Viana [do Alentejo]", soube depois que o Governador tinha perguntado por ele com intenção de o levar consigo, o que não pôde acontecer, e por isso lhe manifesta o seu reconhecimento por via epistolar. Dessa carta conservase, felizmente, o texto autógrafo, cuja primeira página se pode ver reproduzida no fim deste estudo, o que 
permite verificar o seu estilo ortográfico redigido por sua própria mão e comprovar tudo o que temos dito sobre esta matéria. Vejamos os seus dois primeiros parágrafos:

Mighel da Arruda, stando V. S. en Cepta, me deu os primeiros motiuos de deseiar seruir V. S. hos quaes eu assi en mi criei $\&$ accrescentei, com ho tempo que me descobrio en quem \& quam bẽe empregaua este deseio, que fiquei para eu poder stimular \& accarretar outrem a ipso, \& ia non poder com razam ser en epsa parte mais que outrem stimulado. Porque isto alcançam haquelles que en qualquer genero de virtudes $\&$ habilidade se fazem signalados, que ha meesma virtude $\&$ habilidade assim quomo hos faz ser cognescidos de todos, assi hos faz de todos hos bóos ser amados. [...] (Veja-se Carta a D. João de Castro, ANTT, Ms. da C. de São Lourenço, IV, fol. 52).

A grafia de 'Mighel' com a aspirada -h- exemplifica a função que na ortografia resendiana ela exercia para assinalar o carácter oclusivo da consoante g- quando seguida de -i- ou -e-, expediente que o humanista repete habitualmente em idênticas situaçóes, v.g. em 'entreghe', 'gherra', 'gherreiros', 'fogheado'. Note-se também a grafia alatinada de "signalados", que outras obras igualmente documentam, por exemplo, em 'signal' e 'signo' (o sino da torre); a ausência de nasalização no pronome 'mi', forma que o autor prefere por ser mais condizente com a origem latina mihi; e ainda, a palavra 'meesma', cujas vogais geminadas evocam a sua origem do latim metipsima, e do mesmo modo a nasal de 'bóos', que denuncia a forma latina bonos. 
Outro dos textos portugueses de André de Resende que tem especial interesse para a análise da sua ortografia é o Sermão que ele pregou no sínodo de Évora em 1 de Fevereiro de 1565 e publicou em Agosto de mesmo ano. Transcrevemos um pequeno excerto em que o pregador dominicano proclama a obrigação que sobre todos os homens impende, mas principalmente sobre os sacerdotes, de imitarem neste mundo as virtudes celestes. Vejamos por esta amostra o interesse e a novidade ortográfica que ele contém:

"Et se a todos, quanto mais aa hierarchia ecclesiastica, que na terra mais representa hakella beatissima ordẽe do ceo. Porque quomo esta ciidade de Deos é hũa s[cilicet] hũa Hierusalem, \& nos mediâte ha fee, scriptos por ciidadãos de'lla, [...] posto que inda ca stemos nos arraualdes d'ella, assi quomo tẽemos ha voz \& appellido por el Rei quomo hos de dentro, assi tẽemos obligaçam de nos côformar \& unir nos costumes \& linguagẽe com hakelles que nas plaças \& castello d'ella ja moram." (Vd. Sermão de 1565, [p. 1]).

De entre as formas latinizantes sublinhadas, e pondo de parte as que já foram comentadas em outros passos, destaco a grafia greco-latina dos nomes técnicos 'hierarchia ecclesiastica' e 'Hierusalem', o conjuntivo arcaico 'stemos', que transcreve a própria grafia latina, e a presença da líquida originária em 'plaças', correspondente à forma latina platea, bem como os vários casos de geminadas, quer vogais, quer sobretudo consoantes.

Mas o caso curioso, e que constitui uma novidade, é o uso do -k- em 'hakella' e 'hakelles'. Trata-se de um 
expediente puramente gráfico para substituir o dígrafo -qu-, talvez para evitar o risco de que o apêndice velar -u-do mesmo dígrafo se pronunciasse nos casos em que ele não tivesse valor fonético ${ }^{4}$. Mas isto nada tem que ver com questóes etimológicas. Resende utiliza-o em mais dezassete casos deste Sermão, não apenas neste tipo de adjectivos ou pronomes demonstrativos incluindo 'hakillo', mas também nos seguintes vocábulos: 'frakeza', 'eskeescidos', 'tokeis', 'kebra', 'haki', 'skerda', e nas expressões 'hacté hakelle' e 'hacté haki'. Mais cinco anos depois, veio a usá-lo por duas vezes na Vida de Frei Pedro, com as palavras 'keente' e 'kebra' (fol. a vij; e fol. a viij $\left.v^{o}\right)$.

Por último, transcrevemos alguns passos da História da antiguidade da cidade Évora, preferindo para o efeito o texto da primeira edição, de 1553, uma vez que a segunda, saída a lume postumamente a 1 de Fevereiro de 1576, apesar de ostentar na folha de rosto a notícia de que ainda tinha sido "emendada pelo mesmo autor", falecido havia mais de seis anos, apresenta uma ortografia irregular, incoerente e em muitos casos fora do critério sempre demonstrado por André de Resende. É verdade que a segunda edição apresenta vários acrescentos ao texto da primeira, os quais poderão constituir a tal operação de emenda do autor nela referida. Mas esse é outro aspecto da crítica textual, que não directamente

${ }^{4}$ Fernão de Oliveira, em 1536 , escrevia a tal respeito no cap. IX da sua Grammatica da lingoagem portuguesa: "Tiramos dantras nossas letras .k. porque sem duuida elle antre nos não faz nada: nem eu nunca vi em escritura de Portugal esta letra .k. escrita." Por isso talvez tenha sido esta uma novidade de André de Resende. 
da ortografia. O confronto das duas ediçóes mostra que o editor da segunda, ou o tipógrafo, ou ambos, nem sempre respeitaram a marca ortográfica de mestre André de Resende.

Posto isto, vamos então ao texto resendiano de 1553 acerca da antiguidade de Évora, cuja transcrição tem o objectivo de demonstrar que aquela marca vinha de longe e se manteve em toda a produção de Mestre André em língua portuguesa. Para isso escolhemos alguns extractos da dedicatória feita ao príncipe $\mathrm{D}$. João, filho de D. João III, que havia nascido naquela mesma cidade áulica:

A ho principe nosso senhor.

Muito alto, \& muito poderoso principe, \& senhor nosso.

Lembrame que beisando eu ha mão a .V. A. en Almeirin, oclhou vossa A. pera o arcebispo de Lisbóa, \& perguntoulhe quem eu era, \& tornando se a mi, me dixe que lhe perdóasse que me non cognescera. [...] Mas cô todo la fica inda ha diuida do seruiço que prometti, por ho qual, per minha meesma bocca stou empegnado. Hora medindo minhas forças, $\&$ considerando que hos homẽes dados aas leteras, com leteras seruẽ a hos Reis \& principes, \& que ho tal seruiço a hos meesmos foi acceptissimo, en isto me determinei. [...] paresceo me bẽe tornar ante vossa .A. com esta historia desta sua cijdade Euora. Que por .V. A. en ella nascer, tẽemos sabido que vossa A. lhe quer bẽe quomo a patria, \& ella a V. A. tẽe quomo patria, \& ella a .V.A. ama quomo a filho, \& en elle se reuee quomo en speclho. (Vd. História da antiguidade da ciidade Evora, 1553, fol. a vo e a ij-ij vo). 
A maioria dos latinismos ou formas latinizantes aqui sublinhadas, e sua motivação, já foram comentadas a propósito de outros textos, mas importa dizer uma palavra sobre outros casos que o não foram, designadamente a forma verbal 'dixe', que assenta no radical latino dix- dos tempos do pretérito do verbo dicere e que se mantém sistematicamente ao longo da obra resendiana, como em 'dixer', 'dixemos', 'dixesse'; o particípio 'empegnado', cujo -g- denuncia a raiz latina pignus (penhor, garantia); a forma 'speclho', que apresenta o mesmo fenómeno de grafia hiperetimológica de 'oclho' e 'oclhar' já comentados; a palavra 'letera' por 'letra', que reintroduz uma consoante do latim 'littera', e o advérbio 'hora', cognato e simplificação concorrente de 'hagora', derivado do sintagma latino hac hora.

Note-se, de passagem, o latinismo sintáctico da expressão 'cijdade Evora', em vez de 'cidade de Évora', que aparece no próprio título do rosto e se repete nesta e em outras obras de Resende e que representa o fenómeno da concordância apositiva, decalcado na sintaxe latina.

Os textos aqui apresentados pretendem apenas dar uma imagem reduzida (porque o espaço mais não permite) do sistema ortográfico da língua portuguesa seguido pelo polígrafo André de Resende na sua produção vernácula, cuja exemplificação exaustiva daria uma relação de largas páginas compactas.

Este vasto caudal de latinismos gráficos ou de arcaismos latinizantes não foi naturalmente criação exclusiva do nosso humanista. Com efeito, por um 
lado, muitas grafias representam recuperaçóes de modelos arcaicos mais ou menos recuados, entretanto ultrapassados pela progressiva evolução do português; e, por outro, as mesmas opçóes ortográficas eram seguidas por muitos autores contemporâneos de Resende. Mas foi ele, talvez como ninguém no seu tempo, que assumiu e praticou com mais largueza, decisão e persistência a ortografia de tendência etimológica.

Além disso, Resende não foi um teorizador, mas antes um etimologista prático que aplicou na sua obra aquilo que pensava ser a melhor ortografia para a língua portuguesa. De facto, das poucas vezes que escreveu sobre esta questão, fê-lo de forma indirecta, como quando, ao anotar para os estudiosos alguns passos mais obscuros do seu poema sobre o mártir São Vicente, padroeiro de Lisboa (Vincentius Levita et Martyr, Lisboa, 1545; Adnotationes, p. 47, nota 44), se refere à língua comum dos Lusitanos, recebida de seu lendário epónimo Luso, dizendo. "E realmente ainda perduram na nossa língua, que é quase latina, muitos vestígios de helenismo" (Et reuera, durant adhuc in nostra lingua, quae paene latina est, multa Graecitatis uestigia).

Acresce ainda que, no comentário acerca da conjugação dos verbos (De uerborum coniugatione commentarius, Lisboa, 1540, fol. $\mathrm{H} \mathrm{v}^{\mathrm{o}}-\mathrm{Hij}$ ), que é a sua única obra de carácter propriamente didáctico, o humanista fala sobre "certos homens, aliás sábios e amigos," com pretensão a cortesãos e muito preocupados com as elegâncias da corte, mas que "Atiram para a maior pobreza a lusitana língua, essa língua dos mais 
amplos recursos sem dúvida, essa pagem seguidora do falar latino e sua servente doméstica" (Lusitanam linguam amplisssimam illa quidem, Latinique sermonis pedisequam familiaremque uernaculam, in magnas angustias detrudunt). E a seguir, falando dos benefícios da importação linguística quando devidamente ponderada como os clássicos sempre fizeram, lamenta os hábitos portugueses e ironiza deste modo:

"Nós, é ao contrário. Fazemos, na verdade, tanto descaso do que é nosso, que até da riqueza da língua fugimos com horror. E ninguém julgue que eu digo estas coisas por estar extremamente apaixonado pela língua portuguesa, à qual eu deixarei de todo morrer, desde que ela se transforme na romana que outrora tivemos." (Nos contra. Adeo enim nos nostri piget, ut etiam ab linguae copia abhorreamus. Nec uero quisquam me haec arbitretur dicere, quod multum Lusitanam linguam deamem, cui per me sane perire licebit, modo in Romanam, quam olim habuimus, mutaretur.).

Portanto, e à parte as possíveis ironias, Resende parece que veria com muito prazer que a sua Lusitânia voltasse a falar a língua do Lácio como nos tempos áureos da romanização. Este sentimento explica-se por ele ser não apenas um dos maiores humanistas do renascimento português, mas também um dos competentes estudiosos da história da antiguidade portuguesa e mesmo ibérica, e um especialista em epigrafia latina. É nessa qualidade que, a propósito da ortografia da própria língua latina, numa carta que servia de dedicatória de uma obra intitulada Antiqua 
Epitaphia dirigida ao cardeal D. Afonso, irmão de D. João III, defendia que a melhor ortografia é a oferecida pela epigrafia, pura e simplesmente porque as pedras não mudam, ao passo que a erosão humana tudo transforma e adultera (Pinho 2006: 162-165).

Mestre André de Resende, profundo conhecedor das línguas antigas que estão na base do português, excelente polígrafo em todos os campos da literatura, exímio orador e devotado especialista da história antiga, estava pois especialmente vocacionado para defender e sobretudo praticar uma escrita portuguesa que preservasse a ortografia na sua mais directa matriz original, o padrão da língua latina. Foi isso que ele fez, assumindo na prática o protagonismo de um movimento etimologista de recondução às fontes.

Mas não foi um caminho fácil. Se muitos autores e teóricos seus contemporâneos alinharam na mesma empresa, outros nem por isso.

Entre as vozes autorizadas que elogiaram o critério ortográfico aplicado na sua produção literária vernácula com base na origem da lingua latina, contase o gramático Pêro de Magalhães de Gândavo, que em 1574 no Diálogo que acompanha as suas Regras, evoca e associa ao nome de Joáo de Barros, o do humanista André de Resende, e onde também ressoa a voz de Camóes: "Pois se quereis ver a lingua de que [a portuguesa] he mais vizinha, \& donde manou, lede a arte da grammatica la lingua Portuguesa que o mesmo Ioam de Barros fez, e o mesmo podeis ver no liuro da antiguidade de Euora de Mestre André de Resende, 
onde claramente se mostra, que cô pouca corrupção deixa de ser Latina.” (Gândavo 1574: fol. D viij).

Mas dois anos depois, o gramático Duarte Nunes de Leão, que na carta-dedicatória da sua Ortografia exprime os mesmos conceitos de Resende quanto à preservação da verdadeira ortografia através da epigrafia (Leão 1983: 44), já na Regra II da mesma obra defende claramente o critério fonético "Porque não consiste a polícia da língua portuguesa em as palavras serem mais conjuntas e parecidas com as latinas"; e logo depois lança a seguinte farpa que parece talhada para o humanista eborense: "Pelo que é nojenta escritura e fora de razão a dos que dizem Princepsa, por Princesa, e epse, por esse, e oclho, por olho, e comptar, por contar, por ser mais conforme ao latim,” etc. (LEÃo, 1983: 133).

Reflexos desta crítica e oposição às propostas radicais da ortografia etimológica e latinizante de André de Resende ainda se verificaram em tempos modernos pela voz da grande filóloga Carolina Michaëlis de Vasconcelos, que, a propósito das anomalias da escrita portuguesa do seu tempo, e da necessidade de uma reforma nacional, escrevia numa das suas liçóes de filologia portuguesa (Michaëlis de Vasconcelos s.d.: 104): "Caturrices como cognoscer por conhecer, quomo por como, oclhos por olhos, hacte por até, haghora por agora, ipso por isso - obras do benemérito antiquário André de Resende! - não vingaram felizmente."

Caturrices e exageros ou náo, a verdade é que a escrita latinizante praticada pelo humanista eborense e por outros escritores do seu tempo (incluindo, embora 
de forma hesitante e híbrida, alguns dos gramáticos que teoricamente a contestavam) perdurou, a partir deles e em grande medida, por cerca de quatrocentos anos até à reforma ortográfica simplificada de 1911, que mesmo assim não simplificou de todo algumas das propostas daquele sistema gráfico de tendência histórica e etimológica, ainda hoje vigentes no traje oficial da ortografia da língua portuguesa. 


\section{BibLIOGRAFia}

Barros, João de (1540), Grammatica da lingua Portuguesa [e] dialogo em louvor da nossa linguagem. Lisboa, Luís Rodrigues.

GÂndavo, Pêro de Magalhães de (1574), Regras que ensinam a maneira de escrever e orthographia da lingua portuguesa, com hum dialogo que adiante se segue em defensam da mesma lingua [...]. Lisboa, Officina de Antonio Gonsaluez.

LeÂo, Duarte Nunes de (1983, Ortografia e origem da lingua portuguesa. Introdução, notas e leitura de Maria Leonor Carvalhão Buescu. Lisboa, Imprensa Nacional - Casa da Moeda.

Leitão Ferreira, Francisco (1916), Notícias da vida de André de Resende. Publicadas, anotadas e aditadas por Anselmo Braamcamp Freire. Lisboa, Arquivo Histórico Português.

Michaëlis de Vasconcelos, Carolina (s.d.), Lições de filologia portuguesa, segundo as prelecçóes feitas aos cursos de 1911/12 e de 1912/13, seguidas das liçôes práticas de português arcaico. Lisboa, Dinalivro.

Silva Neto, Serafim da (1947), A santa vida e religiosa conversação de Frei Pedro, porteiro do Mosteiro de S. Domingos de Évora. Rio de Janeiro, Ediçôes Dois Mundos. 
Oliveira, Fernão de (1536), Grammatica da lingoagem portuguesa. Lisboa, Germáo Galharde.

Pereira, Virgínia Soares (1988), André de Resende, Carta a Bartolomeu de Quevedo. Introdução, texto latino, versão e notas. Coimbra, Centro de Estudos Clássicos e Humanísticos da Universidade de Coimbra.

Pinho, Sebastião Tavares de (2006), Humanismo em Portugal. Estudos I. Lisboa, Imprensa Nacional Casa da Moeda.

Resende, André de (1547). "Carta a D. João de Castro, Lisboa 16 de Março de 1547”, ANTT, Manuscritos da C. de S. Lourenço, IV, p. 52-53. 


\section{ANEXo II \\ Primeira página da Fala de André de Resende à PRINCESA D. JOANA}

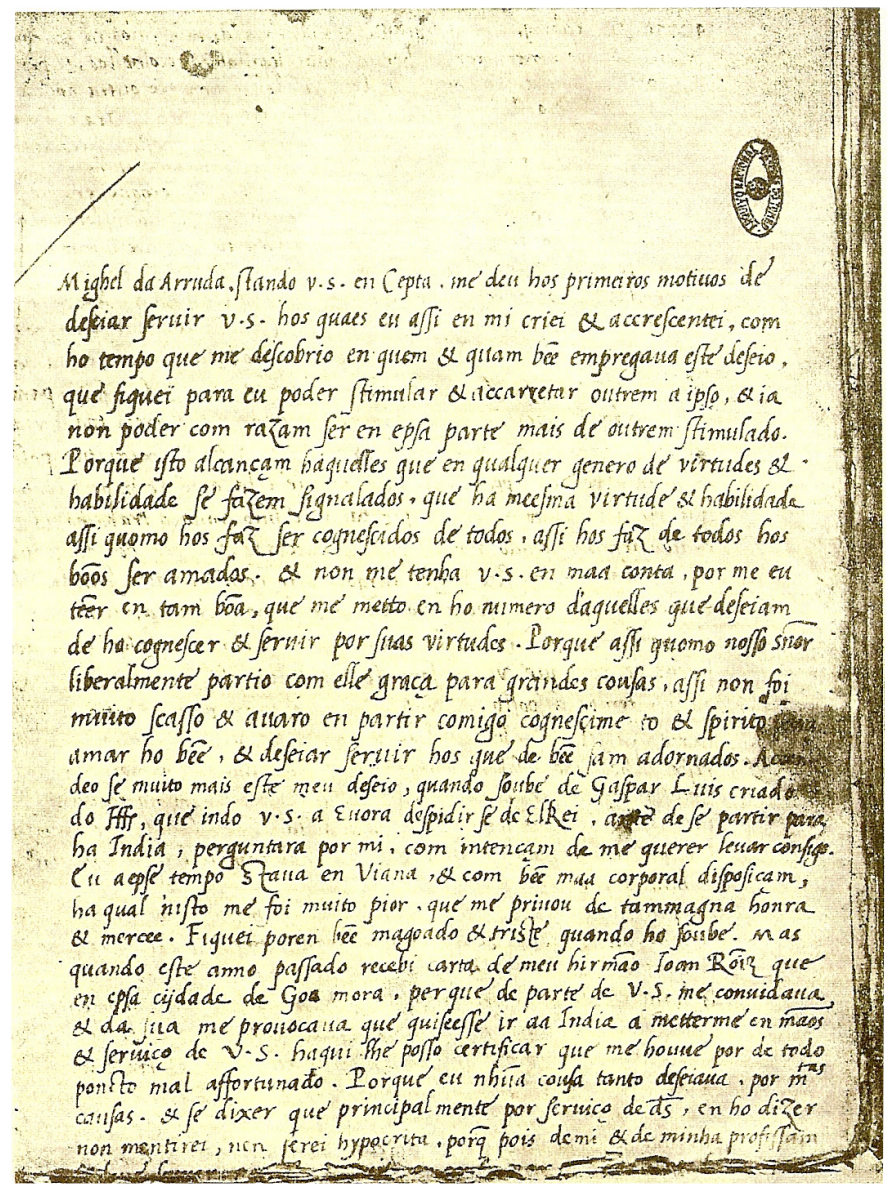




\section{$38 \delta^{2}$

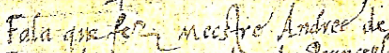

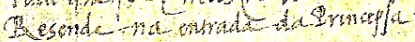

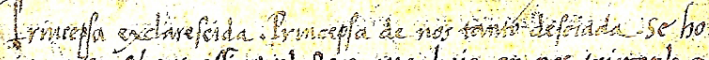

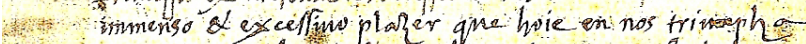
pér pal auras fe podeffe explicar, mus ponco ferna fo qua

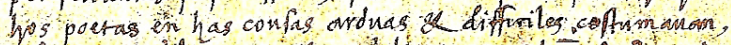

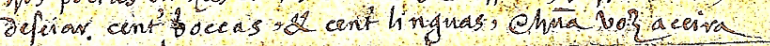

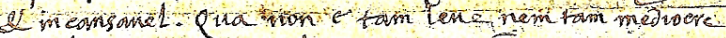

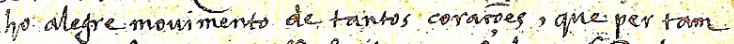
poncos informmentog affi faehmente fe lex alfebedaras.

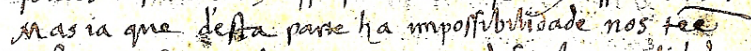
Defengamad, 2 de on no nodere ha gralidale 00 tempo ans com longa orarar detenta a V:A.

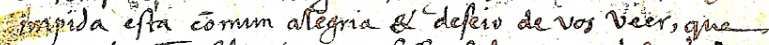

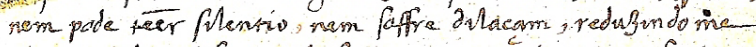

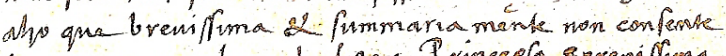
ha nam gre lege de dizer, Prinespla geremifima,

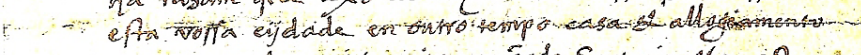

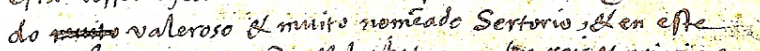

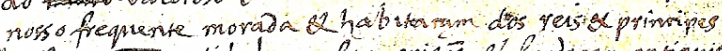

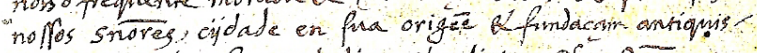
sima, of en tia fue eathalica of religiom Chroftar sware todas has de fifpania on mais antigna, on tanto quan.

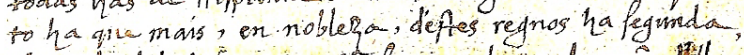

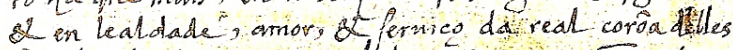
fen dumida ha primersa, beja vorpas reaes más, al pare qus publice al geral vorn com hos anmos cheos de.

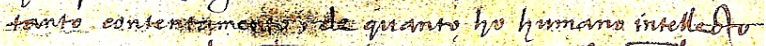

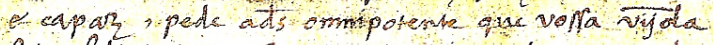
feia felieigrima. Entrou snora per los mines ofos

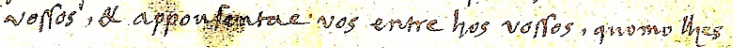


André de Resende e Jerónimo de Azambuja:

DA INTERPRETAÇÃO DOS TEXTOS MOSAICOS

Virgínia Soares Pereira 
"Por isso quis dar disso testemunho perante Vossa Alteza" André de Resende

\section{I}

O presente estudo centra-se no comentário, edição e tradução de uma carta de André de Resende dirigida, em 1557, ao Cardeal-Infante D. Henrique, em jeito de prefácio ao Levítico, comentado por Jerónimo de Azambuja. Sem ser uma peça eloquente, mas atendendo ao destinatário, a carta náo deixa de revelar a personalidade de um humanista de grande prestígio que em todas as circunstâncias percebeu a proximidade entre eloquência e política.

\section{Breve introduçáo}

Na carta em referência, André de Resende, teólogo dominicano, exalta perante o Cardeal o trabalho exegético de Azambuja, igualmente teólogo dominicano, e pôe o acento tónico na dificuldade de interpretação do texto hebraico, que dificilmente pode ser lido e compreendido sem o auxílio de comentários. A carta, em rigor, nem é nuncupatória nem é prefatória, parecendo antes um misto das duas modalidades. Qual a sua real intenção?

Jerónimo de Azambuja (?-1563), também conhecido como Oleastro (forma latinizada de 
Azambuja), ${ }^{1}$ teólogo e inquisidor, é considerado um dos exegetas portugueses mais insignes de todos os tempos. ${ }^{2}$ Detentor de um notável conhecimento da língua hebraica, filólogo e comentador escriturístico de alta craveira, Azambuja já no seu tempo viu reconhecido o seu valor, a avaliar pelos testemunhos que Barbosa Machado regista no respectivo verbete da Bibliotheca Lusitana. Fez a sua formação em Portugal (frequentou em Lisboa, em 1525, o Colégio Universitário de S. Tomás) e em Lovaina (em cuja universidade se encontra no ano de 1536). Regressado à sua terra natal, e depois de ensinar em Lisboa e em Évora, foi escolhido por D. João III, em 1545, para participar no Concílio de Trento. Será pouco tempo depois, ainda antes de o Concílio terminar, nomeado deputado da Inquisição, "com o especial encargo da censura dos livros". ${ }^{3}$ A partir de 2 de Setembro de 1552, é-lhe confiado o Tribunal do Santo Ofício, em Évora, e em Outubro de 1555 passa a

${ }^{1}$ Natural de Alenquer, segundo A. A. Martins Marques (196466: 193), que considera que Azambuja é apelido de família e não indica a sua terra natal. Por seu turno, M. Augusto Rodrigues (1973: 17-18) considera-o natural de Azambuja.

2 Palavras de Manuel Augusto Rodrigues (1977: 25). Veja-se, do mesmo autor (1974: 16-19), uma súmula da vida de Azambuja e bibliografia.

3 A. A. Martins Marques (1964-1966:196); vd. também pp. 201-203, nas quais fala da importância e originalidade de Oleastro na organizaçáo do Índice de livros de 1551, apesar de Azambuja se ter porventura inspirado no Índex elaborado pela Universidade de Lovaina em 1550, segundo Raul Rego (1982: 41-46). No exercício das suas funçóes de deputado da Inquisição de Lisboa, preocupou-se essencialmente com os livros estrangeiros que entravam em Portugal, consciente de que poderiam atentar contra a integridade e ortodoxia da doutrina católica. 
exercer o cargo em Lisboa, mantendo-se nele até 1560, na sequência da sua eleição como Prior Provincial dos Dominicanos. Do conjunto da sua produção exegética, destacam-se os Commentaria ad Mosi Pentateuchum e os In Isaiam prophetam Commentarii.

Por sua vez, André de Resende (1500-1573), um dos grandes vultos intelectuais da Évora quinhentista, notabilizou-se como prestigiado humanista, dividindo o seu tempo entre as actividades de teólogo, pregador dos cardeais D. Afonso e D. Henrique, professor de príncipes e nobres, arqueólogo, historiador, biógrafo, gramático, poeta... Formou-se em Teologia Sagrada, mas sempre tentou conciliar os estudos bíblicos com os estudos clássicos, na esteira dos ensinamentos de Erasmo, defendendo a ideia de que a verdade cristã não é incompatível com a elegância clássica.

Com tais curricula, importa perceber em que momento(s) é que os caminhos e saberes de um e de outro se cruzaram, a ponto de Resende ser chamado a prefaciar um Comentário de Azambuja a um texto hebraico.

Segundo revela o próprio Resende na referida carta ao Cardeal, os primeiros contactos de André de Resende e Jerónimo de Azambuja datavam do período da sua adolescência. Apesar do carácter vago das suas palavras, que não permitem precisar datas, supóe-se que terão sido companheiros de estudo no mosteiro dominicano, talvez em Évora, antes de, em 1513, Resende rumar à Universidade de Alcalá de Henares. Mais tarde, regressados um e outro a Portugal, depois 
de concluída a sua formação em terras estrangeiras, tiveram ocasião de conviver em Évora (terra natal de Resende e área de acção de Azambuja como inquisidor, de 1552 até 1555) e Lisboa (lembre-se que neste ano passou a exercer o cargo na diocese de Lisboa e Resende, que preferia Évora, apenas em serviço do Cardeal se deslocava à capital do reino), em suma, nas cidades onde, além de Coimbra, se desenrolava o essencial da actividade política, religiosa e intelectual do país. ${ }^{4}$

$\mathrm{Na}$ qualidade de teólogo e professor de Sagrada Teologia, Resende teve de se dedicar ao estudo da língua hebraica, talvez em Lovaina, no Colégio Trilingue. Foi aqui que, segundo C. Michaëlis de Vasconcelos, Resende estudou rudimentos de Hebraico e cultivou as línguas clássicas, travando conhecimento e convivendo em estreita amizade com os mestres mais prestigiados, como o Campense (que foi mestre de Hebraico no Colégio Trilingue de Lovaina, de 1520 a 1531), Rogério Réscio, Conrado Goclénio e Nicolau Clenardo, exercitandose com este na língua hebraica "um pouco de tempo" e trazendo-o mais tarde a ensinar em Portugal. ${ }^{5} \mathrm{Na}$ verdade, Clenardo ensinou Hebraico e Grego em Lovaina e, entre outras obras, é autor de uma Tabula in Grammaticam Hebraeam. ${ }^{6}$

${ }^{4}$ Sobre Évora e a sua importância política, social, intelectual e artística, pois era a segunda cidade do país, no séc. XVI, veja-se Luís de Matos (1976).

${ }^{5}$ Vd. M. Cerejeira (1974 -1975, II: 96). É o próprio Resende que, num dos seus frequentes e por vezes inesperados registos autobiográficos, como o que surge no cap. X da Vida do Infante D. Duarte, refere estes dados.

${ }^{6}$ M. Augusto Rodrigues (1984: 128). Este estudioso informa 
O conhecimento da língua hebraica por parte de Resende não se faz sentir na sua obra, a não ser escassamente. Assim, no final do Livro IV do Aegidius Scallabitanus, falando da etimologia de hursacrum (usagre) e apoiando-se no saber dos médicos de origem judaica, afirma que se trata de um composto híbrido formado de uma palavra hebraica (hur, que corresponderia ao grego pyr e equivaleria ao latim ignis, 'fogo') e do lexema latino sacrum ('sagrado'). ${ }^{7}$

No registo meramente linguístico, esta é uma das poucas abonaçóes da língua hebraica em Resende. Mas quando nos referimos ao conhecimento dos textos bíblicos, nesse caso a preparação de Resende é indiscutível e reflecte-se em várias obras. Lembre-se o primeiro sermáo que pregou no Sínodo de Évora, em 1534, no tempo do Cardeal-Infante D. Afonso. Nesta elegante peça de oratória sacra, em latim, o humanista estrutura e desenvolve o tema da necessidade de morigeração dos membros da Igreja com base na frase do profeta Joel $(2,15-16)$ que diz: Vocate caelum, congregate populum, sanctificate ecclesiam, coadunate

(p. 133) que Clenardo tinha a intenção, manifestada em carta a Fr. Brás de Braga, de estabelecer o ensino da língua sagrada nos Claustros de Santa Cruz de Coimbra, em 1537. Este mesmo autor (1973: 12), referindo-se ao ensino do hebraico no Colégio das Artes, em Coimbra, lembra que "não era permitido ensinar hebraico e outras disciplinas em escolas privadas ou públicas, salvo nas Escola Gerais e nos conventos da cidade.” Daqui em diante, o interesse pelo hebraico irá redobrar, dada a necessidade de os católicos responderem com rigor às posiçóes dos reformadores e heréticos.

${ }^{7} \mathrm{Vd}$. texto, tradução e notas em André de Resende (2000: 604605 e 695 , n. 28). 
senes. A fim de sustentar a sua argumentação, e bem assim as duras críticas que dirige ao estado da Igreja, apoia-se em vários passos bíblicos, nomeadamente do Velho Testamento, comentando em especial o passo de Ezequiel (16, 1-63), "a famosa e belíssima alegoria da infidelidade de Jerusalém, comparada com uma esposa ingrata e adúltera", no dizer de Sebastião Tavares de Pinho. ${ }^{8}$ Mais tarde, nas famosas adnotationes ao poema Vincentius, leuita et martyr, 1545, encontramse, em jeito de justificação de expressóes do seu poema, referidos e comentados vários episódios bíblicos. ${ }^{9}$

Um segundo sermão, proferido também em Évora no sínodo diocesano de 1565, trata o tema da santificação dos eclesiásticos partindo do Salmo 99, vers. 5: Congregati illi sanctos eius, qui ordinant testamentum eius, super sacrificia. Neste sermão, que constantemente apela a citaçóes veterotestamentárias, nomeadamente dos livros do Pentateuco, são duramente atacados Lutero e outros heréticos por pretenderem, sem autoridade, "non somente inquirir, mas condemnar ho que fixo e firme stava." ${ }^{10}$ Distando entre si duas décadas, estes sermões, elegantes e fortes, constituem o que de mais relevante Resende compôs na área da Sagrada Escritura.

${ }^{8}$ Para o conhecimento deste importante sermão, veja-se Isaías da Rosa Pereira (1971: 171-232) e Sebastião Tavares de Pinho (2006: 153-182), que considera o comentário de Resende à alegoria de Ezequiel uma das críticas mais acerbas que foi possível fazer aos desvios da Igreja e à degradação dos seus membros.

${ }^{9} \mathrm{Vd}$. André de Resende (1981: 72-81).

10 Para o estudo deste sermão, vd. Isaías da Rosa Pereira (1991-1992: 190-201). 
Mais saberíamos sobre o interesse de Resende pelos textos bíblicos, se fosse possível conhecer o recheio da sua biblioteca pessoal, que seria grande. Mas os dados de que dispomos são escassos. Um dos mais importantes colhe-se no seu testamento, começado a exarar por volta de 1570 , no qual declara, a dado passo: "Leixo a minha livraria ao moesteiro de Sam Domingos, convem a saber, a que pertence a Teologia, Sagrada Escritura, Filosofia, Historia ecclesiastica, Exposição de Autores, e outros livros, que elles julgarem, que lhe sam necessários (...).” E mais adiante, referindo em especial certos livros: "Particularmente leixo o meu livro grego Ioane Climacho, de Ascensu in Caelum, e huma Biblia hebraica Aldina da impressam de Aldo ao Collegio de Ihesu, e assim a Biblia grega toda." ${ }^{11}$ As duas obras referenciadas em especial destaque, a Bíblia Hebraica e a Bíblia Grega, são uma prova claríssima do interesse de Resende pelos estudos bíblicos e, em particular, pelo texto hebraico da Bíblia. Com a sua veia filológica, não terá deixado de fazer um estudo comparativo dos textos do Antigo Testamento e suas traduçóes, como fez Azambuja.

\section{A obra de Azambuja}

Da sua obra de exegeta chegaram até nós os Commentaria in Mosi Pentateuchum e os In Isaiam prophetam Commentarii. São duas obras de grande fôlego, densamente filológicas, por um lado, e de

${ }^{11}$ Transcrito de F. Leitão Ferreira (1914: 225-226). 
orientação moral, por outro. De facto, é uma constante do seu trabalho de exegese apresentar, para cada capítulo, o comentário ad litteram (isto é, o comentário que visa o sentido literal) seguido do comentário $a d$ mores (o comentário que procura apreender o sentido espiritual). Na edição de 1557, esta dupla modalidade de comentário vem assim titulada (exemplo do cap. 30): Capitis XXX. Iuxta literam annotationes e Capitis XXX. Ad morum compositionem annotata.

A quem não esteja familiarizado com a natureza e os pressupostos destes Comentários, importa referir que os princípios que nortearam Azambuja no seu imenso trabalho de exegese se encontram registados nos dezasseis cânones que ele mesmo elaborou e que figuram a encabeçar o texto desses Comentários. ${ }^{12}$ São várias as ideias directrizes expendidas. Assim, considerava que só o conhecimento das duas línguas do Velho Testamento, o Hebraico e o Grego, permitiria o acesso aos textos bíblicos. São poucos, contudo, os que sabem Hebraico. Nesse caso, aconselha-os a que se sirvam, como ele mesmo fez, da tradução para latim de Sanctes Pagnino. ${ }^{13}$ Mas está ciente da novidade (perigosa) deste

${ }^{12}$ Sáo conhecidos com o título de Hebraismi et Canones pro intellectu Sacrae Scripturae e, tanto quanto se sabe, nunca tiveram edição separada. Além das orientaçôes necessárias a quem queira penetrar nos arcanos do texto bíblico, Azambuja elaborou listas de palavras e expressóes que são próprias do idioma sagrado (os chamados hebraísmos).

13 Sanctes Pagnino (1470-1541?), O.P., foi um dos mais célebres hebraístas do seu tempo. Publicou em 1528, em Lyon, a obra Vtriusque instrumenti noua translatio, uma tradução da Bíblia a partir dos textos originais, que constituiu uma verdadeira 
conselho. Lembra, por isso, a quem possa estranhar que não tenha aconselhado a traduçáo latina conhecida por Vulgata, oficialmente sancionada pela Igreja de Roma, que esta traduçáo náo está isenta de erros, um facto que o próprio S. Jerónimo, autor da Vulgata, reconhecia. ${ }^{14}$ Sem temer o escândalo que adviria de emendar a Vulgata, o comentador propunha-se uma exegese secundum hebraicam ueritatem. Pelas mesmas razóes, não mostrava interesse em citar a opiniáo dos padres da Igreja, preferindo citar as próprias Escrituras Sagradas, exactamente por considerar que só o texto original da Escritura é inspirado. ${ }^{15}$ Em todo o caso, em muitos passos póe a sua interpretação à disposição do juízo crítico dos outros, afirmando que podem discordar dela e ater-se à versão tradicional.

revolução na sua época. A sua tradução do Antigo Testamento foi, desde S. Jerónimo, a primeira a ser feita directamente do texto hebraico. Levou vinte e dois anos a realizar o trabalho e a sua divisão em capítulos e versículos permanece inalterada até aos nossos tempos. Pela mesma altura publicou em Lyon o Thesaurus linguae sanctae, "um léxico hebraico bastante desenvolvido", segundo informação colhida em Manuel Augusto Rodrigues (1984: 128).

${ }^{14}$ É no Prefácio ao leitor, que antecede os Comentários, que Azambuja refere este dado, acrescentando que não pretende denegrir S. Jerónimo, mas que o considera um homem, não um profeta. São estas as palavras: Quae non in eum finem adducimus, ut uirum sanctum traducamus, sed ut sententiamus eum non Prophetam, sed hominem. Como lembra Manuel Augusto Rodrigues (1974: 17), Azambuja chegou mesmo a propor ao papa Paulo IV que ordenasse a correcção da Vulgata tendo em atenção os textos originais.

${ }^{15}$ Para um conhecimento inicial dos Commentaria de Azambuja e do seu método exegético, veja-se A. A. Martins Marques (1966: 123-150). 
Esta sua preocupação era própria de quem tivera uma sólida formação humanística e conhecia a verdadeira importância do estudo aprofundado dos textos sagrados para alcançar o seu cabal entendimento. Lorenzo Valla, Lutero e Melânchton advogavam a necessidade de tomar em mãos os textos bíblicos originais para aí se encontrar a palavra de Deus. Também Erasmo (na Ratio perueniendi ad ueram Theologiam) insistia neste ponto. Opunham-se todos à exegese tradicional e escolástica, bem como ao texto da Vulgata, que na Idade Média era, por assim dizer, a Bíblia oficial da Igreja latina. Voltará a sê-lo depois do Concílio de Trento, que em 1546 fixou a versão jeronimita como o texto oficial da Igreja. ${ }^{16}$

Defender, como Azambuja faz, ideias tão inovadoras e ousadas no seu tempo, aplicando aos textos sagrados o método de que se serviam os grandes humanistas, só terá sido possível pelo facto de ele mesmo ser inquisidor e ter a protecção do Cardeal, Inquisidor-Mor. Os seus Comentários revelam-se de uma grande riqueza filológica e hermenêutica e foram, logo no seu tempo, muito apreciados pelos especialistas. Mas a sua independência como exegeta bíblico, que nem todos compreenderam e alguns censuraram, terá contribuído para que, apesar de membro destacado da Inquisição, tenha visto a sua obra incluída no Index de 1624. Houve mesmo quem sugerisse que o facto de assinar com o termo latino Oleaster (Oleastro) ${ }^{17}$ poderá ter sido uma forma de "iludir" a autoria da obra.

${ }^{16} \mathrm{Vd}$. M. Augusto Rodrigues (1984: 112).

${ }^{17}$ Oleaster,-tri, '(a)zambujeiro'. 


\section{A carta de André de Resende ao Cardeal-Infante D. Henrique}

A carta elogiosa de André de Resende data de 15 de Julho de $1557 .{ }^{18} \mathrm{O}$ rei D. João III falecera a $11 \mathrm{de}$ Junho de 1557, em Lisboa. De acordo com informação do próprio, Resende fora chamado ao serviço do cardeal D. Henrique e encontrava-se em Lisboa no exercício de incumbências cuja natureza não é revelada. Neste entretanto, na tentativa de se distrair um pouco do ambiente opressivo que se vivia no país, na sequência da morte do rei - que partia sem deixar qualquer filho vivo, encontrando-se a sua sucessão entregue à regência da Rainha D. Catarina, avó do príncipe Sebastião, de três anos apenas ${ }^{19}$-, Resende visitava regularmente Fr. Jerónimo de Azambuja, então inquisidor em Lisboa,

${ }^{18}$ Esta carta, entre o prefácio e a dedicatória, saiu impressa em Lisboa, a anteceder os Commentaria in Leuiticum, editados em Lisboa em 1557, na Oficina de João Blávio. Neste mesmo mês de Julho e na mesma tipografia que imprimiu os Commentaria in Leuiticum prefaciados por Resende, este humanista imprimiu igualmente o poema à morte de D. João III, que se apresenta com o seguinte título: L. Andreae Resendii in obitum D. Joannis III. Lusitaniae Regis, Conquestio. Permissu et auctoritate Reuerendissimorum Inquisitorum. Olisipone, apud Joannem Blauium Typographum Regium, mense Julio. M. D. LVII. A respeito deste poema, veja-se a notícia de F. Leitáo Ferreira (1910: 357-358) e as respectivas notas de A. Braancamp Freire.

${ }^{19} \mathrm{O}$ facto de D. João III e D. Catarina terem visto morrer, ano após ano, todos os seus filhos enlutou profundamente a Casa Real e o país e marcou um período de grande tristeza nacional. A morte do rei veio adensar esse clima e lançar a incerteza quanto ao futuro do país, mergulhado numa crise sem precedentes. A carta de Resende alude a esse sentimento geral de perda e de luto. 
que aproveitou o ensejo para lhe dar a conhecer os Comentários ao Pentateuco, em que andava a trabalhar. Encantado com a qualidade da obra e com a sua extrema utilidade, em particular para aqueles que, sabendo um pouco de hebraico, sentiam dificuldades em entender o texto e o sentido das Sagradas Escrituras - era, de resto, o seu próprio caso, como confessa -, Resende decidiu apresentar a obra ao Cardeal D. Henrique. Para tal, escreveu a carta que apresentaremos no final, em texto latino e tradução. ${ }^{20}$

Três motivos moveram Resende a escrever a carta: 1. Fazer o elogio do amigo, encarecendo as suas qualidades naturais e a sua erudição. $O$ humanista eborense admira nele a extraordinária cultura bíblica e o domínio perfeito da língua hebraica. E tinha razão no elogio. Segundo M. Augusto Rodrigues, Azambuja foi um "exímio comentador escriturístico e filólogo consumado" e contribuiu com o seu denodado esforço exegético para uma maior inteligência do texto sagrado. ${ }^{21}$ Além deste motivo, outros dois: 2. Uma convivência de longa data, desde os tempos da adolescência, no convento dominicano de Évora. Finalmente (retoricamente last, but not least): 3. O facto de Azambuja desempenhar, a convite do Cardeal, as funçóes de inquisidor, um cargo "tão importante quanto perigoso". E assim, nestes três motivos, eram apregoadas três qualidades: as

${ }^{20}$ Não conheço qualquer tradução desta carta. M. Augusto Rodrigues (1977: 29-31) dá a conhecer excertos dela, mas não os traduz, fazendo deles um breve resumo e comentários.

${ }^{21}$ M. Augusto Rodrigues (1977: 26). 
do talento natural e erudição, as da velha amizade e a institucional...

A ilustrar a extraordinária competência de Azambuja na interpretação do texto bíblico, Resende chama particular atenção para o passo Gen. 30, que tem que ver com a história de Jacob e Labão - aquele episódio bíblico que seria imortalizado entre nós pelo famoso soneto camoniano que começa: Sete anos de pastor Jacob servia. Nessa história bíblica, Jacob é em várias ocasióes ludibriado por Labão. A fim de encarecer as competências exegéticas do amigo, Resende fala das dificuldades que enfrentou para dar sentido à astúcia de que Labão, patriarca, reiteradamente usou para com Jacob. Mas não é explícito quanto à natureza dessas dificuldades. E a leitura do comentário de Azambuja não auxilia muito à compreensão da afirmaçáo de Resende. Talvez se possa depreender das suas palavras que a dificuldade de interpretação residiria, não no sentido literal, alcançável mediante uma rigorosa análise filológica, mas sim na interpretação (e sentido moral) a dar ao conhecido episódio.

No comentário de Azambuja ao episódio, figuram inúmeras observaçôes filológicas e hermenêuticas, relativamente às quais admite que o leitor possa não estar de acordo com a sua leitura e preferir a leitura tradicional. Diz, dirigindo-se ao leitor em pleno comentário do referido capítulo 30:

Parce prudens lector si quod intelligo, expressi: quoniam non prohibeo communem interpretationem. Confer quae diximus, 
et si probaueris, tene, sin minus, reiice. Dominus ipse nouit quid laboris pertulerimus in eruendis ueris dictionum signifcationibus. $^{22}$

Isto é, o próprio comentador confessa que a sua interpretação não é a tradicional. Só Deus sabe, confessa, quanto esforço lhe exigiu tentar descobrir o verdadeiro sentido das palavras! O comentário de Resende parece glosar este passo.

Em muitos outros passos Azambuja não esconde haver no texto bíblico trechos de difícil interpretação, que nem as conjecturas ajudam a resolver. Para dar mais um ou dois exemplos, atente-se no comentário relativo ao passo bíblico que fala do sinal posto por Deus a Caim. Diz o Gen. 4: Et posuit Dominus ipsi Cain signum, ut non percuteret illum omnis inueniens eum. ${ }^{23}$

Comentando o sentido deste sinal, Azambuja escreve:

Non solum, ut non occiderent eum, sed etiam ne percuteretur. Quod signum hoc fuerit, textus non explicat, neque est aliqua coniectura ad hoc sciendum, neque libenter in sacris literis historias fingo. ${ }^{24}$

22 "Desculpa, avisado leitor, se exprimi o que penso, pois não impeço a interpretação comum. Analisa o que disse e, se estiveres de acordo, toma-a para ti; se não, deita-a fora. O próprio Senhor sabe quanto trabalho suportei na descoberta do verdadeiro sentido das palavras."

23 "E pôs o Senhor um sinal ao próprio Caim, para que todo aquele que o encontrasse o não ferisse."

24 "Não apenas para não o matarem, mas também para não o ferirem. Que sinal seria este, o texto não o explica, nem há 
Há que relevar, neste caso, a isenção de quem, atendo-se ao sentido literal, nada mais pode acrescentar. De natureza bem diferente é o comentário relativo às palavras (que constam do referido capítulo 30 do Génesis): Iratus est furor Iaacob in Rachel ("Jacob enfureceu-se contra Raquel”), que dão conta da reacção de Jacob às preces da mulher que queria ter descendência. Estas palavras foram comentadas da seguinte forma: "Debent uiri immoderata uxorum desideria arguere et temperare", isto é: "Os homens devem censurar e moderar os desejos sem medida das esposas". Azambuja tenta desculpabilizar a atitude pouco compreensiva de Jacob, responsabilizando moralmente a mulher. Mas o que aqui importa reter não é o conteúdo dos comentários, ditados pelo tempo em que foram redigidos, antes a sua dupla natureza, literal e moral.

Passemos agora ao último ponto da carta. Depois de elogiada a qualidade dos extensos comentários de Azambuja, Resende justifica o teor das suas palavras prefaciais. Elas destinam-se a testemunhar, perante o Cardeal, o valor do homenageado. Assiste-se então a um sub-reptício auto-elogio, quando o próprio Resende sublinha a magnanimidade de quem é capaz de reconhecer no outro o mérito que lhe é devido. Este tópico tornara-se numa espécie de leit-motiv das preocupaçóes de Resende, pois muitas vezes se sentira esbulhado do reconhecimento a que tinha direito. Por isso náo deixava de criticar aqueles que dificilmente

conjectura que possa levar ao seu conhecimento. Além do mais, não é de bom grado que forjo histórias nos textos sagrados." 
valorizavam o trabalho dos outros, como deixou dito na carta De aera Hispanorum, de 1551, ou, mais tarde, na Carta a Bartolomeu de Quevedo, de 1567. ${ }^{25}$

E aqui chegamos ao cerne desta carta. De facto, prefaciar uma obra sempre foi, para o prefaciador, uma das formas de se fazer lembrado, de afirmar a sua consonância com o pensamento ortodoxo e de revelar a sua personalidade. Enfim, de se mostrar, eloquentemente, perante o poder.

${ }^{25}$ Veja-se, a este título, Virgínia Soares Pereira (1987-1988), maxime pp. 211-216. 


\section{ANeXo III \\ Carta de André de Resende ao Cardeal D. HenriQue}

\section{Nota prévia}

O texto que serviu de base à presente edição da carta de Resende é o que consta do volume intitulado:

Reuerendi Patris Fratris Hieronymi Ab Oleastro Lusitani, Praedicatorii Ordinis, ac Sacrae Theologiae Professoris, atque haereticae prauitatis apud Inclytam Olyssiponem Inquisitoris Commentaria in Mosi Pentateuchum, iuxta M. Sanctis Pagnini Lucensis eiusdem ordinis interpretationem: quibus Hebraica ueritas exactissime explicatur: \& quae ad morum compositionem aptari possunt: ex ipsius literae penetralibus seorsum annectuntur. Opus sane, $\&$ doctis, $\&$ indoctis usui futurum. Olyssipone apud Iohannem Barrerium Regium Typographum. Anno a nato Seruatore nostro Iesu Christo M.D.L.VI. ${ }^{26}$

Note-se que o frontispício do volume, apesar de abarcar toda a obra (os cinco livros do Pentateuco), regista um impressor (João Barreira) e uma data (1556) que são válidos apenas para os Commentaria in Genesim, porquanto os restantes quatro livros tiveram ediçóes em separado. São eles: Commentaria in Exodum /.../.

${ }^{26}$ Apenas os três primeiros livros têm cartas prefatórias, a primeira de Jerónimo de Azambuja, a segunda de Jerónimo de Brito e a terceira de André de Resende. Jerónimo de Azambuja é ainda autor de uma carta nuncupatória ao Cardeal D. Henrique e, a iniciar os Comentários ao Exodo, surge uma carta elogiosa de Jerónimo Osório a Azambuja. 
Olyssiponi (sic), Ex officina Ioannis Blauij Coloniensis. M.D.LVII; Commentaria in Leuiticum /.../. Olisipone, Apud Ioannem Blauium, typographum regium. M.D.LVII; Commentaria in Librum Numerorum /.../. Olyssipone, Ex officina Ioannis Blauij Coloniensis. M.D.LVII; Commentaria in Librum Deuteronomii /.../. Olissipone, Exofficina (sic) Ioannis Blauij Coloniensis. 1558. M.D.LVIII. ${ }^{27}$

O exemplar desta obra que consultei encontra-se na Biblioteca Pública e Distrital de Braga (Cota Res. 676 V) e é proveniente do Convento de Viana. ${ }^{28} \mathrm{~A}$ título informativo, diga-se que nesta valiosa Biblioteca de Braga existem exemplares de várias edições quinhentistas da obra de Azambuja. ${ }^{29}$ Segundo M. Augusto Rodrigues, alguns dos exemplares dos Commentaria in Pentateuchum

27 Curiosamente, no verso do fólio 69, no final do Deuteronómio, vem escrito o seguinte: Expliciunt Comentaria (sic) magistri Hieronimi ab Oleastro Lusitani ordinis praedicatorum quos. 28. die mensis Maii anni. 1557 Vlisipone absoluit. Mais curioso é que o volume do Deuteronómio ostenta na folha de rosto a data de M. D. LVIII.

${ }^{28}$ Conforme se lê na folha de rosto desta edição quinhentista, em nota exarada em letra manuscrita, o exemplar é proveniente do Convento de Nossa Senhora do Carmo de Viana.

${ }^{29}$ Existem na Biblioteca Pública de Braga exemplares das seguintes ediçóes quinhentistas de Azambuja: Commentaria in Mosi Pentateuchum, Olyssipone apud Iohannem Barrerium Regium Typographum, 1556 (Cota: Res. 676 V); Opera. Antuerpiae, In aedibus Viduae \& Haeredum Ioannis Stelsij. M.D.LXVIII (Cota: 2995 V.); Commentaria in Pentateuchum Mosi, Lugduni, Apud Petrum Landry, 1588 (Cota: R. 2140 P.); Opera. Antuerpiae, João Stelsii, 1569 (Cota: R. 1686 P.). Já do séc. XVII existem os In Isaiam prophetam Commentarii. Paris, Sebastiâo Cramoisy, 1622 (Cota: R. 1924 P.). 
foram expurgados pela censura inquisitorial. Dos exemplares que compulsei nem todos foram vítima de rasuras. ${ }^{30}$

O texto que se segue tem como base o da primeira edição (Lisboa, 1557). Feita a sua colação com a edição de Antuérpia, de 1568, e a de Lião, de 1588, não se registaram divergências textuais, pelo que não há necessidade de apresentar o aparato crítico. Introduziram-se, no entanto, algumas alteraçóes, que respeitam as normas de modernização em vigor na edição de textos antigos. A saber:

O símbolo \& foi substituído por et; o grupo -ij foi transcrito $-i i$; as vogais encimadas por um til foram transcritas com $-m$ final, como: $-\tilde{a}>-a m$; os grupos -oe- e -ae-foram registados como -e-; desfizeram-se abreviaturas, como: iterumq:, que se transcreveu iterumque.

A fim de facilitar a leitura da carta, introduziram-se parágrafos inexistentes no texto de base.

${ }^{30}$ Foram vistas as primeiras três ediçôes referidas, verificandose que a carta prefatória de Azambuja ao leitor foi rasurada no exemplar com a cota $2140 \mathrm{P}$. As rasuras incidem em especial no passo em que Azambuja explica a sua preferência pela tradução de Sanctes Pagnino e náo pela Vulgata. Este exemplar procede "Da Communidade de N. Sa do Populo" (pertence ms.) e, em nota manuscrita da folha de rosto exara-se: Expurgatus. Por isso M. Augusto Rodrigues (1979: 191), salientando a importância do prefácio azambujano ao Pentateuco, afirma: "pensamos tecer-lhe alguns comentários à medida que transcrevemos as partes mais significativas, pois ele foi riscado de muitos exemplares pela censura inquisitorial." A carta de Resende não foi objecto de qualquer censura. 


\section{Diui Emmanuelis Lusitaniae Regis,}

Pii, Felicis, Inuicti filio, D. Henrico,

S. R. E. tituli Sanctorum quatuor coronatorum presbytero

Cardinali,

ac primo Eborensis ecclesiae Archiepiscopo,

Domino suo,

L. Andr. Resendius, indignus

sacrae theologiae professor

S. P. D.

Adcitus a te Olisiponem, Princeps sacratissime, et a meis studiis aliquantisper feriatus, dum domo absum, et ea quorum gratia me aduocaras perficio, soleo conuenire interdum religiosum ac bene doctum uirum $F$. Hieronymum Oleastrensem, sacrarum literarum ex illustri Diui Dominici instituto professorem, adlectum per te in hac Olisiponensi dioecesi ad inquirendum de haereticis, et in tenenda religione factiosis. Quod tametsi libenter facio, et propter uiri non uulgarem eruditionem, et quia olim a prima fere adolescentia in coenobiali conuersatione studia coniunxeramus, ob id tamen libentius, quod dignum eum ipse iudicasti, quuius fidei prouinciam non minus magnam quam periculosam, et summa morum ac religionis integritate indigentem, delegares.

Interea obruente nos Diui Ioannis III, fratris Germani tui, regis autem nostri ${ }^{31}$ et, ut uere dicam,

${ }^{31}$ Note-se que também no poema Conquestio à morte de $\mathrm{D}$. João III, editado no mesmo ano, Resende afirma como D. João era, mais do que rei, "pai da pátria": (...) qui patriae, potius quam rex, pater atque magister / iure bono dicendus erat (vv. 58-59). 
patriae parentis, interitu, ac dum iusta non persoluuntur insequuto iustitio, quum tum ex publica maestitia, tum uero ex tua, animo nescio dissolutione magis, an destituto, ad illum uenissem, legendos mibi dedit suos in Genesin et Exodum commentarios, non longos illos quidem, sed quantum ad rem attinet longe copiosissimos. Quos cum ego, partim ut languenti animo sacrarum literarum lectione subuenirem, quibus et professionis instituto, et mentis propensione, quasi obaeratum me sentiebam, partim ut adultae iam aestatis caloribus intra parietes facilius me absque taedio continerem, attente et cum delectu semel iterumque legissem, immane dictu quam placuerint, quam probauerim, quam amauerim, quam studiosis omnibus ex Hebraicae linguae salebris germanum literae et contextus

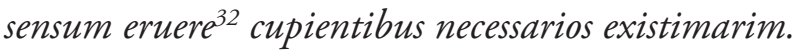

$V t$ de me ipse loquar, ex non paucis equidem obscurorum locorum difficultatibus, quasi oborta insperato luce tandem euasi, et ab aliquot qui me diu torserant nodis

${ }^{32}$ Confronte-se com o que Azambuja escreve na pág. 167 do seu Commentarius ao Génesis, 49-1: Elaboranimus ergo huius capitis germanum sensum: ex his quae praediximus et ex significatione propria uerborum, quoad fieri poterit, obstrusum sensum eruere, (...) - citado de A. A. Marques Martins, 1966, p. 142-143. Na pág. 179 de Quorundam Locorum, o exegeta refere-se à importância do conhecimento do contextus para um correcto entendimento da Sagrada Escritura: Dico enim ibidem litterae genuinum sensum ex contextu uenandum: cum uerba quae praecedunt, nullo pacto debeant uirgini accomodari, cum non sit filia naga, aut rebellis, qualis ibi dicitur sinagoga: non puto locum ad litteram de ea loqui. (cit. de A.A. Martins Marques (1966: 140). Comentando o passo Et ait Leah, Azambuja escreve: In exercitum, id est, tantam filiorum copiam habeo, quod possent exercitum constituere. Et re uera iste est germanus literae sensus (...). 
sum extricatus. ${ }^{33}$ Imputent hoc imbecillitati qui uelint, et ingenii mei quam et ipse fateor tenuitati, et quanto libeat supercilio ac fastu imputent, modo, ut de multis uel unum hoc adducam, ex trigesimi Geneseos capitis posteriore parte, in qua de Iacob cum Laban conuentione et patriarchae astu agitur, sine linguarum praesidio, si possunt, sese expediant. Summa haec est. Ego me hisce commentariis legendis profecisse confirmo, ac alios itidem profecturos certo polliceor, eos praecipue qui saltem mediocrem linguae sanctae peritiam habuerint. ${ }^{34}$ Id tuae Celsitudini, Princeps sacratissime, testatum propterea uolui, quod noster ipse Hieronymus eos tuos tibi iure dicauit. Simul, quia candoris maxime ingenui est, laboribus alienis, si per illos profeceris, gratiam habere, si non profeceris, neque etiam detrahere. Vale, Olisipone Idibus Iulij. M.D.LVII.

${ }^{33}$ Como se comprova com o texto transcrito na nota anterior, e como se deduz do seu prefácio, também Azambuja confessa a dificuldade que sentiu em interpretar muitos dos passos, mas acrescenta que obteve progressos, pois com esforço conseguiu descobrir certos sentidos que antes lhe eram inteiramente obscuros.

${ }^{34}$ Azambuja confia igualmente em que a sua obra será de grande utilidade para os outros. A afirmação, recorrente, vem exarada logo na folha de rosto, ao dizer: Opus sane et doctis, et indoctis usui futurum. 
A D. Henrique, filho de D. Manuel, rei de Portugal, Pio, Feliz, Invicto, Cardeal da Santa Igreja Romana, Presbítero do Título dos Quatro Santos Coroados, e primeiro Arcebispo da Igreja de Évora, seu Senhor,

L. André de Resende, humilde Professor de Teologia Sacra, envia muitas saudaçóes.

Chamado por ti a Lisboa, Sacratíssimo Príncipe, e estando um tanto liberto dos meus estudos, por me encontrar ausente de casa, a dar cumprimento às incumbências que motivaram a tua convocação, tenho o hábito, de vez em quando, de me encontrar com Fr. Jerónimo de Oleastro, varão de grande religiosidade e cultura, professor de Letras Sagradas do ilustre instituto de S. Domingos, por ti nomeado para o exercício das funçóes de inquisidor dos heréticos e dos que renegam da religião, nesta diocese de Lisboa. ${ }^{35}$ Faço-o, sem dúvida, de bom grado, não apenas atendendo à invulgar erudição desse homem, mas também porque em tempos, praticamente desde os inícios da adolescência, compartilhámos os estudos na conversação cenobial, mas faço-o ainda mais gratamente pelo facto de tu mesmo o teres julgado digno de nele delegares o encargo da fé, táo importante quanto perigoso e necessitado da maior integridade de costumes e religiosidade.

${ }^{35}$ Recorde-se que Jerónimo de Azambuja era inquisidor em Lisboa desde 1555. 
Entretanto, neste momento em que se abate sobre nós a morte de $\mathrm{D}$. João III, teu irmão verdadeiro, mas também rei nosso e, em boa verdade, pai da pátria, e enquanto não se realizam os seus funerais, passado o período do luto público, fui visitá-lo - de alma combalida, ou por motivo da tristeza pública, ou verdadeiramente da tua, não sei se mais afectado pela sua morte, se pelo desamparo - e ele deu-me a ler os seus Comentários ao Génesis e ao Êxodo, não extensos, de facto, mas, no que ao assunto diz respeito, de longe mais bem extensos. ${ }^{36}$ Ora, tendo-os eu lido, em parte para acorrer em auxílio ao meu ânimo languente mediante a leitura das Sagradas Escrituras - relativamente às quais me sentia como que penhorado, não apenas em conformidade com o meu ofício, mas também por inclinação de espírito -, em parte para mais facilmente me manter em casa e sem tédio, pois iam já avançados o verão e a canícula, - tendo-os eu lido uma e várias vezes com atenção e com deleite, é-me impossível exprimir quanto me agradaram, quanto os aprovei, quanto os apreciei, quanto os considerei - dadas as dificuldades da língua hebraica - necessários a todos os estudiosos interessados em descobrir o verdadeiro sentido da letra e do contexto.

Para falar de mim próprio, vi-me livre, finalmente, de não poucas dificuldades respeitantes a

${ }^{36}$ É estranho que Resende se refira deste modo aos Comentários de Azambuja, se se atender a que, quando prefaciou o Levítico, já tinham saído (e ele tinha visto) os Comentários ao Génesis (que se estendem por 316 páginas), ao Exodo (com 96 fólios) e ao próprio Levítico (com 67 fólios), para não falar dos Comentários aos Números (86 fólios) e ao Deuteronómio (67 fólios). 
passos obscuros, como se de repente me surgisse uma luz, e deslindaram-se-me alguns nós que durante muito tempo me tinham atormentado. Que quem o queira impute o facto à minha debilidade e à fraqueza - que eu próprio reconheço - do meu talento, e a seu bel-prazer, de sobrolho carregado e com orgulho o impute, se for capaz de por si só, sem o auxílio de intérpretes, resolver, para citar um só exemplo de entre muitos, o passo Génesis 30, segunda parte, na qual se fala do encontro de Jacob com Labão e da astúcia do Patriarca. Em suma. Pela minha parte, atesto que me foi muito proveitosa a leitura destes Comentários, e garanto, sem a mínima dúvida, que aproveitará de igual modo a outros, especialmente àqueles que tenham um domínio pelo menos mediano da língua sagrada. Por isso quis dar disto testemunho perante Vossa Alteza, Sacratíssimo Príncipe, atendendo ao facto de o nosso próprio Jerónimo tos ter dedicado de pleno direito. Decidi fazê-lo, também, porque é próprio de um carácter particularmente cândido ficar reconhecido aos trabalhos de outrem, se graças a ele se alcançar proveito, e também, se acaso se não alcançar, também não os denegrir.

Adeus. Nos Idos de Julho de 1557. 


\section{BibLIOGRAFia}

Cerejeira, M. Gonçalves (1974-1975), O Renascimento em Portugal: I - Clenardo e a sociedade portuguesa; II-Clenardo: o Humanismo e a Reforma, Coimbra, Coimbra Editora Limitada.

Ferreira, F. Leitão (1910), "Notícias da vida de André de Resende", publicadas, anotadas e aditadas por A. Braancamp Freire, Arquivo Histórico Português VIII, 338-366.

— - F. Leitão (1914), "Notícias da vida de André de Resende", publicadas, anotadas e aditadas por A. Braancamp Freire, Arquivo Histórico Português IX, 177-285.

Marques, A. A. Martins (1966), "A obra exegética de Fr. Jerónimo de Azambuja. Breve comparação dos comentários", Theologica, Braga, 1, 123-150.

—, A. A. Martins (1964-1966), "Frei Jerónimo de Azambuja e a sua actividade inquisitorial", Lusitania Sacra VII, 193-216.

Matos, Luís de (1976), "Ebora Humanistica”, A Cidade de Évora, 59, 5-21.

Pereira, Isaías da Rosa (1991-1992), “Os sermões de André de Resende nos sínodos de Évora de 1534 e de 1565 e as falas de Francisco de Melo no sínodo de 1534", Humanitas, 43-44, 185-201.

_ (1971), "Sínodo Diocesano de Évora de 1534”, 
Anais da Academia Portuguesa de História, 2a série, vol. 20, 171-232.

Pereira, Virgínia Soares (1987-1988), "Uma carta de André de Resende reconstituída", Humanitas 3940, 211-232.

Pinho, Sebastiāo Tavares de (2006), Humanismo em Portugal, Estudos I, Lisboa, Imprensa NacionalCasa da Moeda, 153-182.

Rego, Raul (1982), Os Índices expurgatórios e a cultura portuguesa, Lisboa, Biblioteca Breve.

Resende, André de (2000), "Aegidius Scallabitanus" - Um diálogo sobre Fr. Gil de Santarém. Estudo introdutório, edição crítica, tradução e notas de Virgínia Soares Pereira. Lisboa, Fundação Calouste Gulbenkian, Fundação para a Ciência e Tecnologia.

- (1981), Vincentius leuita et martyr. Reproduction en fac-similé de l'édition de Luís Rodrigues, Lisbonne, 1545. Introduction para José V. de Pina Martins, Braga, Barbosa \& Xavier.

Rodrigues, Manuel Augusto (1973), "O estudo do hebraico em Portugal no século XVI”, O Instituto, Coimbra, 136, 1-46.

_ (1974), "A cátedra de Sagrada Escritura na Universidade de Coimbra", Biblos, Coimbra, 50, $1-612$. 
(1977), "Alguns aspectos da obra exegética de Fr. Jerónimo de Azambuja (Oleastro), O.P.”, Revista Portuguesa de História, Coimbra, 17, 25-36.

_- (1979), “A obra exegética de Fr. Jerónimo de Azambuja”, Biblos, Coimbra, 55, 183-195.

_ (1984), "Les études hébraïques à l'Université de Coimbra (XVIe siècle)", L'Humanisme portugais et l'Europe - Actes du XXI Colloque International d'Études Humanistes, Tours, 3-13 Juillet 1978, Paris, Gulbenkian, 111-160. 
Poesia, Hagiografia E POLÍtica ANTES DA Restauração de 1640

\author{
Carlota Miranda Urbano
}




\section{A Universidade de Coimbra e o desejo de autonomia da coroa portuguesa}

No primeiro quartel do séc. XVII ganhavam peso cada vez mais forte as vozes de descontentamento com o rumo a que a uniáo ibérica conduzira os destinos do reino de Portugal, que se via cada vez mais debilitado na sua soberania e autodeterminação. A cidade de Coimbra, centro cultural e universitário de então, de modo algum se alheava dos destinos políticos do reino. Naquela que fora a primeira capital pulsavam, pelo contrário, destemidos sentimentos e vontades de recuperação da autonomia da Coroa portuguesa. A cátedra e o púlpito, espaços privilegiados para o exercício do poder da palavra, conheceram, de modo mais ou menos velado ou mesmo explícito, o discurso da autonomia como desejo cada vez mais exequível, quanto maior era o descontentamento que de um modo geral se fazia sentir em todo o reino. Se as revoltas populares e os pequenos motins contribuíram para a maturação do movimento que eclodiria na Restauraçáo de 1640, os discursos e oraçóes, a poesia e outras expressóes literárias que faziam parte da vida académica e social de Coimbra, não tiveram responsabilidade menor, não só na maturação desse movimento, como também, mais tarde, na consolidação da Restauração da autonomia tão desejada. 
$\mathrm{Na}$ Universidade de Coimbra do séc. XVII, o 'homo eloquens' era efectivamente 'homo politicus' e o uso da palavra não só contribuiu para a definição dos destinos desejados para o reino, como foi responsável na construção de mitos que se revelariam eficazes na preparação de um Kairos propício à revolução que restauraria a Independência de Portugal como reino soberano.

Os frequentes actos públicos em que brilhava a palavra na vida académica, que se estendia da Universidade aos numerosos colégios que preparavam os seus alunos, ofereciam a ocasião para mover as razóes e os ânimos, para suscitar o desejo e a vontade, para estimular a adesão a determinadas ideias e correntes, por parte do que era uma verdadeira elite intelectual.

A canonização da Rainha Santa Isabel no ano de 1625 foi, sem dúvida, uma destas ocasióes, particularmente privilegiada. $\mathrm{Na}$ verdade, a figura da Rainha Santa Isabel beneficiava há muito de especial devoção em Coimbra, especialmente na Universidade. Por ocasião das festas em sua honra eram pronunciadas oraçóes latinas em seu louvor e compunham-se poemas, que hoje encontramos manuscritos nos códices 993 e 994 da Biblioteca Geral da Universidade de Coimbra. Estes códices constituem um documento da devoção da Companhia de Jesus à Rainha Santa, bem como do seu empenho na canonização da rainha cuja memória era muito celebrada na cidade e na universidade. Deles destacamos, no códice 993, a De vita et moribus Divae Elisabethae Lusitaniae Reginae historia, de Pedro 
Perpinhão, que seria depois publicada em 1609 em Colónia, ainda antes da sua canonização, portanto.

Foi, então, com grande entusiasmo que Coimbra recebeu a notícia da canonização desta Rainha cujas relíquias se guardavam no Mosteiro das Clarissas. Toda a cidade rejubilou e assistiu a vários dias de festa, a expensas do bispo da cidade. A Universidade associou-se, como se descreve na "Relação das Grandiosas Festas que na Cidade de Coimbra hoje por novo titulo ditosa Cidade fez o Illustrissimo Senhor Dó Ioão Manoel Bispo Conde, à Canonização de Sancta Isabel Rainha de Portugal"

"Entrou logo a cidade em suas festas que durarão seis dias. Começarão por hua encamizada em a noite de terça para quarta, estando a cidade toda ardendo em luminarias. Ouue Alcanzias, Touros, Comedias, Manilha, \& Canas. Não se calou nesta occasião da Canonização da Sancta Rainha a Illustre, inclyta, \& Real Universidade, antes com grandes premios conuidou os ingenhos que nella florescem a sairem com poesias, \& a fazerem dizer as Musas, não limitando a lingoa, mas dando a todas o campo, quer Latina, quer italiana, quer Espanhola: não falo na lingoa Portugueza, que essa, como mais eloquente, \& a materna deste Reyno, em que a Sancta Rainha reinou, a primeira era que se conuidaua." ${ }^{1}$

A Universidade festejava o que sentia como verdadeiramente 'seu' e promoveu, de sua parte, como se

1 Manuscrito anónimo que A. G. da Rocha Madail, 10 Conservador da BGU transcreveu e publicou na Revista literária $O$ Instituto, 90 (1936) 4-36. Cfr. p 61. 
pode ler, um certame poético que veio a publicar no ano seguinte juntamente com discursos latinos e sermóes em louvor da Rainha Santa. O Poeticum Certamen ${ }^{2}$ recolhe uma série de poemas hagiográficos, encabeçados pelo Poema epicum, siue heroicum ${ }^{3}$ do então sacerdote da Companhia de Jesus, o P. Francisco de Macedo ${ }^{4}$. É nesta composição poética hagiográfica que nos detemos para observar como poesia e hagiografia exprimiram a intuição do kairós oportuno à exaltação de sentimentos patrióticos e autonomistas que prepararam a Restauração de 1640.

A devoçáo e o culto dirigido a uma figura que se identificava com o reino de Portugal, mais ainda, com a coroa portuguesa, confirmada e reforçada pela canonização, que emanava de uma autoridade internacional como era Roma à altura, só podia contribuir para a identificação nacional com uma coroa soberana e autónoma, livre de qualquer hegemonia castelhana.

\section{O Poeta (fr.) Francisco de (Santo Agostinho) de Macedo}

A figura de Fr. Francisco de Santo Agostinho de Macedo e a sua obra filosófica foram já objecto de

${ }^{2}$ Sanctissimae Reginae Elisabethae Poeticum Certamen dedicat et consecrat Academia Conimbricensis, iussu illustrissimi D. Francisci de Brito de Menezes a consiliis Catholicae Maiestatis et eiusdem Academiae Rectoris, Coimbra, 1626.

${ }^{3}$ Este poema foi mais tarde reeditado na colecção do P. António dos Reis e Manuel Monteiro (1748: tomo VII, 78-94).

${ }^{4} \mathrm{~A}$ autoria das composiçôes poéticas não vem indicada na obra, mas os três primeiros poemas a que nos referimos vêm editados no Corpus ... op. cit. como da autoria do P. Francisco de Macedo. 
estudo de Ilídio de Sousa Ribeiro numa monografia que a Universidade de Coimbra publicou em $1952^{5}$. Interessa-nos aqui, porém, o jesuíta mestre de retórica, faceta também já estudada por Aníbal Pinto de Castro ${ }^{6}$, mais que o professor de filosofia que viria a ser um franciscano de assinalável actividade docente em Roma, Veneza e Pádua.

Francisco Macedo nasceu em 1596 e entrou para o noviciado da Companhia de Jesus, em Coimbra, no ano de 1610. Fez os estudos de Retórica no Colégio das Artes, bem como os de Filosofia e de Teologia. Em 1620, o P. Francisco Macedo era mestre de Retórica no Colégio de St. Antão, em Lisboa. Ensinou depois em Santarém (1625) e foi a notícia do seu talento que o levou a Madrid em 1628 para ensinar Retórica no Colégio Imperial. Em 1630 fez a profissão solene dos quatro votos.

Apesar da admiração que por ele nutria D. Filipe IV e das relaçóes que estabelecera com a corte de Madrid, o P. Macedo náo se inibiu de manifestar o seu inconformismo com a união das Coroas pelo que, em 1637, por ocasião de tumultos anti-castelhanos em Évora, acusado pelas palavras dos seus sermóes, se viu 'encerrado' na Casa Professa de São Roque, em Lisboa onde esteve até 1640. A sua permanência nesta casa, porém, não se relaciona apenas com aquela acusaçáo, mas também com a sua saída da Companhia para o que pediu autorização em 1638. Com a Revolução de 1640

5 lídio de Sousa Ribeiro (1952).

${ }^{6}$ Aníbal Pinto de Castro 2008: 66-70). 
começaria para o P. Macedo uma nova fase ao serviço da legitimaçáo da Dinastia de Bragança ${ }^{7}$. Logo em Fevereiro de 1641 partiu oculto com a embaixada de D. João IV a França, como agente secreto, mas também para dali se dirigir a Roma, ao Geral da Companhia, com o fito de alcançar a dispensa dos quatro votos que lhe permitiria professar noutra Ordem Religiosa. Regressado a Portugal, professou em 1642 na Província reformada de St. António da Ordem Franciscana, província da qual se veio depois a transferir em 1646 para a Província Observante.

Fr. Francisco de St. Agostinho de Macedo acompanhou várias missóes diplomáticas, a pedido de D. João IV, às principais cortes da Europa e foi nomeado cronista do reino em 1650. Posteriormente, o seu prestígio chegou a Roma onde foi professor no Colégio da Propaganda Fide, ensinando Controvérsia, ou Teologia Polémica, a pedido do Papa Alexandre VII, em 1656. Em 1660 foi o primeiro Professor de História Eclesiástica na Universidade de Roma La Sapienza. Em Setembro de 1667 defendeu conclusóes em Veneza e ocupou a cátedra de Filosofia Moral da Universidade de Pádua onde viria a falecer em 1681 .

\section{O Pro Elisabetha Regina Lusitanorum ... poema épico e hagiográfico}

Embora intitulado como 'épico' pelo poeta, na realidade, este poema é uma oratio em verso heróico,

${ }^{7}$ Sobre este aspecto veja-se Marques (1989). 
sem as rituais proposição e invocação, 'impostas' pela prática da epopeia renascentista. A matéria de louvor do herói reveste-se predominantemente da forma descritiva. Só ocasionalmente o poeta canta os 'feitos' de Santa Isabel, a heroína louvada no poema. Em cerca de 500 hexâmetros dactílicos (496), o P. Francisco de Macedo faz o elogio da Rainha Santa, recorrendo à descrição e louvor de um cortejo imaginário composto pelos monarcas do reino desde o início da nacionalidade até D. Sebastiáo, terminando depois com a entrada de Sta Isabel na Glória dos Céus e encerrando a composição com a peroração à pátria enlutada, para que enxugue as suas lágrimas e de novo erga a cabeça, pela mão da nova Santa que tem em seus altares.

A composição começa como um hino de louvor a Sta Isabel, à sua chegada como membro da corte celestial, ela que finalmente trará o descanso à pátria aflita e transformará esta idade de ferro em idade de ouro:

Venisti tandem Lux alma et debita nostris

Ah nimium curis, totiesque vocata Parentum

Nunc prece, nunc lacrymis; requiem allatura, decusque

afflictae patriae: quae ferrea tempora in aurum

convertes; qua nos propius respexit ab alto

Omnipotens Genitor, uultuque afflauit amico. ${ }^{8}$

Vieste enfim, doce auxílio, a nossos muitos cuidados [destinado,

${ }^{8}$ Reis e Monteiro (1748: VII 78 vv 1-6). 
tantas vezes invocada pelas preces e pelas lágrimas dos [nossos avós para trazer o descanso e a glória, à pátria aflita; tu, que hás-de converter em ouro esta idade de ferro, pois, por tua graça, Deus Pai Omnipotente volveu para nós, lá do alto, o seu olhar favorável.

O poeta abre a composição com os dois tópoi que lhe dão razão de ser: a canonização da rainha que os portugueses há muito queriam venerar nos altares e a graça da libertação da pátria que ela trará aos portugueses. Parece-nos clara a dupla leitura a fazer destes versos. A alegria da canonização é motivo de esperança para aqueles que pretendem repor a integralidade da soberania portuguesa, pondo fim à uniáo das duas coroas, contra a qual, na década de vinte, se vinha agudizando um geral descontentamento. A perda de Ormuz para os ingleses em 1621, a tomada de Salvador pelos holandeses em 1624, a crise de fome que se fez sentir em Maio de 1622, bem como o agravamento dos ataques dos holandeses sofridos pela mesma altura na Foz do Tejo e nas barras do Porto e de Aveiro, e ainda as incursóes de turcos e mouros na costa Algarvia que traziam a população em alvoroço, favoreceram certamente um cima de tensão anti-castelhana.

Esta mesma chave de leitura podemos mantê-la até ao final do poema. Na verdade, aquilo que o poeta trabalha como matéria épica, o carácter heróico de Santa Isabel e os Magnanimi Heroes que em cortejo triunfal nos céus a acompanham, traduz-se num olhar sobre os heróis nacionais do passado para, pela sua exaltação, 
estimular o aborrecimento do presente e projectar a esperança no futuro.

Do céu aberto, o poeta vê descer os heróis nascidos em melhores dias, em cujo reinado outrora se estabeleceu o império lusitano, heróis que nos evocam os feitos da rainha trazendo na mão os sinais e figuraçóes das suas virtudes, e os indícios do presente triunfo de Santa Isabel.

Fallor? An incipiunt portis se effundere apertis

Magnanimi Heroes, nati melioribus annis,

Sub quibus Imperium quondam hoc stetit : altior illis

Maiestas, speciesque angustior: undique corpus

Splendor obit Solem exuperans; intexta coronis

Sidera scintillant, capitum ornamenta; refulget

Dignior, et qualis Superos decet, oris imago.

Reginae hi recolunt ingentia facta, manuque

Virtutum argumenta ferunt, vitaeque prioris

Indicia ostentant, partae nunc praemia palmae, ${ }^{9}$

Mas, é uma ilusão, ou vejo eu que começam a avançar por [estas portas abertas

Heróis magníficos, nascidos em melhores tempos, em cujo reinado um dia este império se ergueu?

É superior a sua grandeza, mais nobre a sua aparência;

o esplendor que os cerca supera o sol

e entretecidas em suas coroas brilham as estrelas, ornameto [da sua fronte; resplandece mais grave a visão do seu rosto, como aos [Santos convém.

${ }^{9}$ Reis e Monteiro (1748: VII 79 vv 39-48). 
Eles trazem-nos à memória as obras sublimes da Rainha, carregando nas mãos os sinais das suas virtudes e ostentam os anúncios dessa vida futura e os prémios da [palma agora alcançada.

Dispensamo-nos de enumerar aqui todos esses heróis e referimos apenas dois dos mais emblemáticos. $\mathrm{O}$ cortejo abre com D. Afonso Henriques que ostenta uma coroa de espinhos, identificando-se assim com o milagre de Ourique. Seguem-se os seus sucessores, todos eles identificados com algo que simbolicamente os associa às virtudes da Rainha, fazendo-os como que participar delas. Entre estes merece destaque D. Manuel que o poeta reconhece pelo globo que traz na mão, aquele que venceu o oceano e os monstros do mar, que aos mundos desconhecidos levou o nosso estandarte, que subjugou a barbárie e os povos infiéis e que, ostentando o globo invoca sobre si a vocação universalista de Portugal.

D. João III, o cultor de Atenas e o novo fundador da Universidade, merece sempre especial destaque em todos os discursos académicos em Coimbra, também aqui nesta oratio em verso.

Encerram este cortejo triunfal dois heróis. Tratase do Cardeal D. Henrique, glória derradeira do reino lusitano, e de D. Sebastião. D. Henrique identifica-se pela veste cardinalícia que, no dizer do poeta, em algo se assemelha à tiara de Pontífice ${ }^{10}$, e traz num quadro

${ }^{10}$ Com efeito, o Cardeal D. Henrique, em 1555 obteve quinze votos na eleição papal. 
a representação da elevação de Santa Isabel aos altares. D. Sebastiáo, esse, vem envolto numa nuvem, em que o poeta divisa o espectáculo desolado de um fim de combate. As insígnias de Portugal estão por terra, a coroa real tombada, um rosto pálido, sujo de poeira, com os cabelos desalinhados pela face, jaz por terra. Estes versos são de intenso tom elegíaco, e prosseguem num Hino ao desejado:

\section{(...) Nec jam te absconde Sebaste,}

Laetitia o Regni breuis, o spes uana tuorum, I

$O$ desiderium, cura importuna, dolorquel

Aeternus, quanqum iustus (...) $)^{11}$

Não mais vos escondais D.Sebastião,

ó breve alegria deste reino, ó vã esperança dos vossos,

ó saudade, cuidado que não tem repouso, dor eterna, posto

[que justa.

O poeta, porém, vê que o fulgor daquele rosto reaparece, e divisa no seu olhar um sorriso. É que Santa Isabel, apiedada do sofrimento lusitano, exorta-o a esperar por melhores dias...

estende a mão àquele que jaz caído,

(...) a custo arrasta os seus membros enfermos,

soergue-o, apoiando-o, e de novo o eleva às alturas do poder; devolve-lhe o ceptro e a coroa:

${ }^{11}$ Reis e Monteiro (1748: VII 91 vv 381-384).. 
Ergo manum labenti offert, (...)

(...) uix et genua aegra trahentem

Sustentatque, leuatque, iterum extollit in altum

Imperii culmen; sceptrum, et diadema reponit. ${ }^{12}$

É então que Santa Isabel encerra este cortejo, transportada no seu carro triunfal. Acompanham-na os anjos, cantando hinos sagrados, e o céu abre as portas de par em par. Santa Isabel senta-se no trono, resplandecendo numa coroa de estrelas. Os últimos versos do poema são um hino de louvor e uma prece. Se Santa Isabel recorda ainda algum amor da mãe que na terra foi, cuide agora de Portugal:

Atque age tutelam Lysiae, et sub numine serua laeta tuo, et quam olim belloque, opibusque superbam Rexisti, fractam refice, atque attolle jacentem. ${ }^{13}$

Zelai, pois, pela defesa de Portugal, guardai-o sob o vosso [braço protector, a nação que outrora, na guerra, governaste soberba em sua [grandeza, agora alquebrada, restaurai-a, erguei-a, que jaz prostrada.

O poeta imagina já os efeitos da nova intercessão. Santa Isabel devolve a honra e o vigor ao reino da pátria.

Quid loquor? aut ubi sum? non Elisabetha iacentem

Eriget; erexit iam, atque ornamenta prioris

${ }^{12}$ Reis e Monteiro (1748: VII 91 vv 393-396).

${ }^{13}$ Reis e Monteiro (1748: VII 92 vv 434-436). 
Restituit famae, primaque in sede locauit:

Virtutemque decusque amissum reddidit, et nos

Degeneres genus ad patrium, roburque reduxit.

Nec iam Massylum gentes, Maurusiaque arua,

Proh dolor! et nostro recalentes sanguine campi;

Nec pestes pelagi insidiae, Algericae triremes:

Nec Batavum, tormentaque dira timorem

Incutiunt: plorat uersis gens impia fatis;

Elisabeth strages, infaustumque omen in illos

Conuertit; deflent sua funera, foeda per illos

Tempestas ruit effuso cum sanguine: nomen

Iam Lusitanum miseri horrescuntque, tremuntque. ${ }^{14}$

Mas, que digo eu? onde estou? Santa Isabel não há-de erguer [essa que jaz, pois ergueu-a já, restituiu-lhe as insígnias da sua glória primeira, colocou-a no seu trono antigo, devolveu-lhe a honra e a [glória perdidas, e a nós, indignos, de novo trouxe a raça e o vigor pátrios. Não mais os povos da Massília, ai dores!, não mais os [campos e as terras dos Mouros hão-de aquecer com o nosso sangue! não mais as desgraças [e as ruínas no mar nem as triremes dos piratas da Argélia! não mais as armadas [dos Batavos lançarão contra nós as suas tremendas máquinas de guerra e o terror. Mudada a sorte, lamenta-se agora essa ímpia nação.

Santa Isabel lança sobre eles a destruição e um terrível presságio. Já choram a sua ruína, abate-se sobre eles a desgraça terrível e o sangue derramado, e, miseráveis, tremem de pavor ao ouvir o nome dos portugueses.

${ }^{14}$ Reis e Monteiro (1748: VII 92-93 vv 437-450). 
No ânimo dos Lusos recrudescem a ira e a honra. Arrebatados pelas armas e pelo ardor de Marte vingarão a pátria e hão-de resgatar o seu nome que jaz sepulto, para que se erga do pó, rediviva, a sua glória.

At Lusis surgunt animis maioribus irae, Ignescitque pudor: rapiunt nos arma, calorque Martius; ulcisci patriam, reparare sepultum Nomen, ut exurgat rediuino e puluere fama. ${ }^{15}$

Era isto, ó Altíssimo, continua o poeta, que guardáveis para Portugal, depois de tantos anos de luto e sofrimento:

"Ó feliz geração a nossa, ó felicidade destes tempos, e felizes [de nós, a quem foi dado viver para ver a nossa Rainha acrescida ao [número dos santos."

O felix aetas, felicia tempora, nosque

Felices! quibus est permissum uiuere, cum iam Reginam caelo adscriptam, Diuumque relatam In numerum nidisse datum est! ${ }^{16}$

A felicidade que provém da canonização de Santa Isabel redime a dor do tempo presente que o poeta já vê transformado pela esperança. Finalmente, os seus últimos versos dirigem-se à Pátria enlutada, para que deponha as vestes fúnebres e enxugue as lágrimas dos seus olhos:

${ }^{15}$ Reis e Monteiro (1748: VII 93 vv 451-454).

${ }^{16}$ Reis e Monteiro (1748: VII 93vv 461-465). 
Ergo maesta Parens longo iam soluere luctu

Lysia, funereos habitus depone, grauesque

fletu attolle oculos ${ }^{17}$...

e de novo se levante, pela mão de Sta Isabel, no esplendor da sua coroa, tal como outrora a Europa a via: vencendo pela espada a África, rasgando o mar alto, chamando ao seio da Fé e à Lei de Cristo os povos longínquos da Ásia, aniquilando cidades, debelando tiranos, trazendo de todo o mundo nobres vitórias:

Talem te ore refert, qualem te Europa uidebat

Vastantem ferro Libyam, et maria alta secantem,

Extremosque Asiae populos, gentesque nefandas

Ad Fidei gremium, Christique ad iura uocantem:

Excindentem urbes, debellantemque Tyrannos,

Et claros domito referentem ex orbe triumphos. ${ }^{18}$

\section{Uma leitura política deste poema hagiográfico}

É evidente a leitura política a fazer deste texto. A figura derrotada que Santa Isabel ergue, a quem devolve o aspecto real, a quem impóe de novo o ceptro e a coroa, começa por ser D. Sebastiáo, moribundo, no campo de batalha, e acaba por ser a própria terra Lusa a quem depois o poeta se dirige até ao final do poema.

${ }^{17}$ Reis e Monteiro (1748: VII 94 vv 475-477).

${ }^{18}$ Reis e Monteiro (1748: VII 94). 
As figuras que vemos desfilar são heróis do passado sobre quem o poeta projecta a excelência, como se pertencessem a uma idade de ouro. A convicção da superioridade e excelência dos monarcas portugueses não é exclusiva deste período da nossa história ${ }^{19}$, mas ganha nele um valor social e politicamente mais pertinente. Os heróis que vemos desfilar preparam um momento central, fora dos limites do tempo cronológico, o 'momento' em que Santa Isabel ergue da ruína o último monarca do desfile, D. Sebastião. Depois da leitura dos passos que citámos, compreende-se perfeitamente o silêncio com que o poeta omite os reis da dinastia filipina. ${ }^{20}$ Embora legitimamente aclamados, não os identificava a nação comum aos portugueses, cuja consciência colectiva se vinha apurando. Além disso, a crise geral que se fazia sentir reforçava o entendimento dos soberanos da dinastia filipina como 'reis estrangeiros'. Este entendimento faz-se acompanhar naturalmente de uma atitude hostil, como curiosamente antevira D. Jerónimo Osório no De Regis institutione. ${ }^{21}$

O jovem rei D. Sebastião e o Cardeal D. Henrique

19 Testemunha-o, por exemplo, o exórdio do De Regis Institutione et disciplina de D. Jerónimo Osório, tratado que dedica a D. Sebastião. Cfr. Soares (1994 : 298).

${ }^{20}$ Três anos depois da publicação desta colectânea, em 1629, na Oração de Sapiência que proferiu na Universidade, o P. Francisco Machado SJ, no habitual tópico de elogio do Rei, escolhe, para louvar, D. João III, omitindo D. Filipe. Veja-se Urbano (2001: 68-71).

${ }^{21}$ Cfr. Soares (1994: 400): "Se a semelhança de vida e de costumes atrai a fidelidade e o amor do povo, a ausência dessas afinidades, que o rei estrangeiro encarna, afasta o consenso unânime e a afeição dos súbditos, indispensáveis ao bem-estar e à estabilidade." 
são inicialmente referidos a par e, logo depois, este último dilui-se no destaque dado ao primeiro. Todo o poema é um crescendo orientado para o momento em que o motivo principal da composição, a canonização e o triunfo da Rainha, escatologicamente se transforma no motivo da redenção da pátria que recupera a integralidade da soberania e se liberta das agressóes externas de mouros e holandeses. ${ }^{22}$

Todo o poema se desenvolve no ambiente fantástico e maravilhoso da visão onírica do poeta, bastante ao gosto da estética barroca. Em última instância, o poema resulta de uma revelação mística. Os heróis são-nos apresentados pelas virtudes próprias ou da Rainha, herói principal do poema. Não assistimos ao decurso da sua acção no tempo, pois eles ultrapassaram já os limites do tempo cronológico. O maravilhoso actuante é, naturalmente, o maravilhoso cristão, omnipresente no poema, e a mitologia é a nacional. Podemos dizer que se trata aqui de um poema épico-místico em que náo conseguimos distinguir a crença nacional da religiosa, porque as duas são inseparáveis. Patriotismo e religiáo são aqui intrinsecamente dependentes.

A esta altura era já corrente em certos meios a ideia, que se veio a generalizar e propagandear depois da Restauração, de que Portugal era detentor de um destino sagrado que consistia em última instância em evangelizar o mundo. Lembremos que Portugal nasceu

${ }^{22}$ Note-se que data do ano da canonização da Rainha, um ano antes da publicaçáo do poema, a reconquista da Baía, até então dominada pelos holandeses. 
em ambiente de reconquista, de cruzada, e que depois se deixou surpreender com as suas próprias capacidades de expandir a cultura latina e cristã num movimento que foi de abertura de novas vias nas relaçóes internacionais, de expansão económica, de proselitismo religioso, movimento interrompido por uma crise geral da nação que se conjugou com a uniáo das coroas de Portugal e Espanha e seus efeitos agravantes naquela crise. $\mathrm{O}$ período do chamado 'domínio filipino' é fecundo na criação ou recuperação de mitos nacionais que contribuem decisivamente para o fortalecimento da consciência colectiva de independência e de soberania. Entre as profecias e as revelaçóes mais variadas, destacam-se o Milagre de Ourique e o Sebastianismo, nas suas diversas tonalidades. No poema do P. Francisco Macedo é o mito do messianismo sebastianista que sustenta a mensagem final e revela o seu significado último, embora o milagre de Ourique esteja também muito presente, não só na função identificadora de $\mathrm{D}$. Afonso Henriques, que abre o cortejo, mas também no pressuposto, presente no poema e mais explícito no final, da vocação universalista de Portugal, um novo 'povo eleito', chamado desde a sua fundação a convocar as naçóes ao seio da Fé Cristã.

$\mathrm{Na}$ verdade, se o milagre de Ourique, oportunamente recuperado neste período, revelava uma fundação divina da pátria detentora de uma missão universal e profetizava a perda da independência e posterior recuperação, entendia-se assim que a opressão que recentemente se agudizava era transitória, 
alimentando-se desse modo a esperança. A evocação deste mito, como afirma João Francisco Marques, constituiu mais tarde, nas lutas de resistência depois da revolução de 1640, 'um expoente dinâmico para a crença no triunfo' ${ }^{23}$.

O mito sebastianista, que nesta altura (47 anos depois de Alcácer-Quibir) não seria já a crença no regresso real do Desejado, surge aqui intimamente associado ao Milagre de Ourique, na medida em que este aponta para o carácter transitório deste período de crise. A recuperação de $\mathrm{D}$. Sebastiâo (o próprio ou a sua revivência num herdeiro da Casa de Bragança) constitui o momento de superação dessa crise. Restituídos o ceptro e a coroa a seu rei, e depois do triunfo da Rainha Santa, o poeta pode cantar, por antecipação, a vitória da nação Lusa a quem Santa Isabel também estendeu a mão. D. Sebastião identifica-se plenamente com o reino. A ruína de um foi a ruína do outro. Por isso era compreensível que a redenção nacional passasse pelo resgate simbólico do seu último rei legítimo (do ponto de vista do poeta). Esta redenção é possível graças à protecção divina por intercessão da Santa, que significativamente é também Rainha, cujas virtudes de piedade e caridade vimos desfilar ao longo do poema.

A longa existência do mito sebastianista, se nele subsumirmos a notável expectativa que a nação colocou no nascimento de $\mathrm{D}$. Sebastiáo a ponto de lhe dar o cognome de $O$ Desejado, ${ }^{24}$ teve neste período grande

${ }^{23}$ Marques (1989:245).

${ }^{24}$ Filho póstumo do último dos nove filhos que D. João III 
repercussão, sobretudo a partir de 1625, quando aumenta no reino o culto profético e a este se associa um cada vez mais geral eco de oposição à união das coroas ibéricas. ${ }^{25}$

Textos como este não só deixavam transparecer o pensamento dos seus autores, como a oscilação dos movimentos políticos, e permitem-nos hoje ajuizar das correntes dominantes no meio em que foram escritos e publicados.

Embora formalmente, como acima dissemos, o poema não use as rituais propositio e invocatio, nem faça uma narratio, compreendemos, no contexto da concepção literária do seu tempo, a designação que o autor lhe dá de poema épico, não só pelo uso do hexâmetro dactílico melhor adaptado à nobreza do tema, mas também pela linguagem e pela matéria. $\mathrm{O}$ louvor da Rainha, agora Santa, transforma-se no louvor dos heróis fundadores de um país e do seu império, heróis que por sua vez são subsídios para o louvor daquela. Num primeiro plano a epopeia faz-se da gesta do herói, neste caso as virtudes da piedade, pobreza e caridade da Rainha, bem como dos seus esforços por conseguir a paz dentro do reino e, num segundo plano, que se vai tornando cada vez mais claro até se explicitar no final, desenrola-se a epopeia de um país que de tão largo império vê perdida a sua soberania,

viu morrer, D. Sebastião não podia deixar de ser tão esperado, e toda a sua existência foi naturalmente marcada pela necessidade de garantir sucessão.

${ }^{25}$ A propósito destas esperanças de autonomia veja-se Serrão, (1979 : IV 104-106). 
esperando, embora, na sua recuperação. A união dos dois planos faz-se claramente na parte final do poema, quando a canonização de D.Isabel não é apenas motivo de alegria per se (e náo esqueçamos o significado político da canonizaçáo da Rainha, como elemento de prestígio diante da Europa católica), mas também (e porque não sobretudo) por, no plano textual, estar eminente a restituição daquela soberania ao país. $\mathrm{O}$ poema, usando embora a descrição da imagem desolada do reino, é sobretudo uma afirmação de optimismo, de confiança no momento (no kairós) na graça e na intercessão do herói principal, Santa Isabel.

Encarnando um desígnio hagiográfico tipicamente medieval que aliava as virtudes da mulher, mãe, soberana, promotora da paz e monja, a figura de Santa Isabel de Aragão, no séc. XVII, proporcionou ao P. Macedo o motivo necessário para a exaltação de sentimentos identitários patrióticos, numa composição poética eloquente e capaz de mouere o 'auditório' a sentir com o poeta. $\mathrm{O}$ mestre de Retórica, e poeta novilatino, é simultaneamente o homo eloquens e o homo politicus.

A identificação com Santa Isabel não corresponde apenas a uma identidade religiosa e espiritual; ela é também social, cultural e política. Ela é expressão inspiradora de uma consciência colectiva, neste caso nacional 'avant la lettre'. Sem retirar uma vírgula ao valor universal da figura modelar da Rainha, reconhecido na canonização oficial, assistimos a um fenómeno de 'nacionalização' da santa. O que náo deixa de ser curioso, 
tanto mais que, como é sabido, D. Filipe III instou junto do Papa no sentido de concluir a canonizaçáo da Rainha, há muito venerada pelos portugueses, e à qual ele se sentia ligado por laços de sangue. ${ }^{26}$ Não obstante, esta mesma canonização é lida como sinal de protecção dos portugueses, com a necessária ruptura em relação à coroa castelhana.

Nesta oratio a que a mestria retórica de Francisco Macedo confere uma voz eloquente e eficaz, Santa Isabel é assumida, usando a expressão de Reginald Gregòire, como 'corresponsável do presente e do futuro da sua comunidade', no caso, o reino de Portugal. ${ }^{27}$

O trabalho de investigaçáo que deu origem a este estudo constitui a principal matéria de um artigo publicado na Humanitas 53 (2001) 343-364.

${ }^{26}$ Brásio (1957: 10-11).

27 Expressão que o especialista em Hagiografia utiliza para caracterizar a relação entre o santo e a 'sua' cidade. Cfr. Gregòire, (1996: 396). 


\section{BibLIOGRAFia}

Brásio, António (1957), Novos documentos para a História da Rainha Santa Isabel, Coimbra.

Castro, Aníbal Pinto (2008), Retórica e Teorização literária em Portugal, 2a ed. Lisboa, Imprensa Nacional Casa da Moeda.

Gregòre (1996), Reginald, Manuale di Agiologia, Fabriano.

Madail, A. G. da Rocha (1936), "Relação das Grandiosas Festas que na Cidade de Coimbra hoje por novo titulo ditosa Cidade fez o Illustrissimo Senhor Dó Ioão Manoel Bispo Conde, à Canonização de Sancta Isabel Rainha de Portugal" O Instituto, 90 4-36.

Marques, João Francisco Marques (1989), A Parenética Portuguesa e a Restauração,(1640-1668), Porto, 2 vol.

ReIs, António e Monteiro, Manuel (1748), Corpus Illustrium Poetarum Lusitanorum qui latine scripserunt, Lisboa, , tomo VII.

Ribeiro, Ilídio de Sousa (1952), Fr. Francisco de Santo Agostinho de Macedo, um filósofo escotista português e um paladino da Restauração, Coimbra.

Serrão, Joaquim V. Serrão (1979), História de Portugal, (1580-1640), Verbo, Póvoa do Varzim. 
SoAres, Nair Castro (1994), O Principe Ideal no séc. XVI e a obra de D. Jerónimo Osório, INIC, Coimbra.

Urbano, Carlota Miranda (2001), A oração de Sapiência do P. Francisco Machado, Estudo. Tradução. Comentário. Lisboa, Colibri. 


\section{DO HUMANISMO COMO FASCÍNIO AO FASCÍNIO DO HUMANISTA: A EXEMPLAR PERSISTÊNCIA DE COSTA RAMALHO*}

Carlos Ascenso André

* Versão ligeiramente corrigida de comunicação apresentada à Academia das Ciências de Lisboa, em 25 de Março de 2010. 
Vai o homem escalando, ao compasso dos anos, as íngremes vertentes dessa montanha incontornável que dá pelo nome de vida. Busca aquele lugar cimeiro onde reside a excelência, palavra de escasso porte, valha a verdade, para traduzir aquilo a que a sabedoria dos Gregos chamava Aretê. Afadigado na subida e preso do desejo de atingir o cume, não cura de olhar em volta e sentir o sossego de algumas sombras reconfortantes, não perde tempo a distinguir as veredas escarpadas dos trilhos mais suaves, não se detém a contemplar, de quando em vez, o caminho percorrido, não intenta alongar o olhar pela paisagem que foi deixando para trás e onde residem, indeléveis, as marcas dos pequenos triunfos de que se fez a subida. Porque o seu objectivo, a sua porfia, o seu prazer residem na própria busca, na procura, ela mesma, e não nas etapas que vai vencendo e nos obstáculos que vai contornando.

Terá tempo - quem sabe? - para tudo vislumbrar de uma vez só, quando alcançar o topo que é, afinal, a meta última do seu peregrinar.

Quando, a meados da década de sessenta do século passado, Américo da Costa Ramalho deu à estampa a sua primeira colectânea de estudos sobre o Humanismo e o Renascimento em Portugal, estaria, talvez, longe de imaginar que inaugurava um percurso de sentido único. 
$\mathrm{Na}$ rota acabada de escolher, de facto, por opção pouco a pouco assumida, náo mais haveria lugar para recuo.

Para trás, ficavam anos de preparação multifacetada, nos domínios múltiplos e pluridisciplinares da Filologia Clássica, a área que, desde a juventude, decidira abraçar.

Foi no Grego que deu os primeiros passos, com uma tese de doutoramento sobre as palavras compostas na comédia aristofânica, com o título de $\Delta \mathrm{l} \pi \lambda \tilde{\alpha}$ ỏvó $\mu \alpha \tau \alpha$ no estilo de Aristófanes, obra de referência, citada pelos melhores editores do comediógrafo, como Stanford, na sua edição da Macmillan; ali chegara, depois de dois anos em Oxford, onde foi aluno de mestres eminentes, como Fraenkel, Dodds ou Denniston. E foi, também, no Grego que a muitos orientou a aprendizagem inicial, com o manual de Grego para o ensino secundário, de que foi co-autor, Tà $\tau \tilde{\omega} \nu$ 'E $\lambda \lambda \eta ́ n v \omega v$.

Já então se evidenciava aquela que viria a ser a sua marca distintiva, ao longo destas mais de seis décadas de investigação e magistério: o amor à palavra. Herdeiro da velha escola da Filologia, é na palavra que assenta o seu labor. A palavra como utensílio, mas também como semente de reflexão. A palavra como raiz de conceitos, mas também como sua expressão. A palavra, esse ser concreto e real de que se forjaram as grandes obras do pensamento humano e da literatura universal. A palavra foi, desde o verdadeiro começo, o seu campo fecundo de trabalho, a vasta seara onde sempre procurou fazer sua ceifa, mas também o instrumental com que a um e outra se entregava. 
Leu os Clássicos. Leu os Humanistas do Renascimento. Neles, porém, sempre se recusou a ler mais do que aquilo que as suas palavras consentiam. Porque cedo aprendeu que só com elas podia desenhar a senda do seu peregrinar por esse mundo de outrora e trazê-lo, sem o desfigurar, até ao presente em que vivia.

Rigoroso, metódico, persistente, meticuloso, sério, incansável, buscou na palavra, sem desfalecimentos, sondar os desígnios do cinzel que os autores que ia estudando manejaram, ao fio dos dias, a esculpirem as obras que nos legaram... esculpidas de palavras, afinal. Com a palavra, estudou a palavra. Não é esse o mister do filólogo?

Foi o que fez com a Literatura Latina, cuja cátedra alcançou em 1954. Laboriosamente a pesquisou, estudou e ensinou, durante décadas - e tantas são as geraçóes que com ele a aprenderam e aprenderam a apreciá-la. Demonstrava conhecer Cícero, como poucos. E Virgílio. E Horácio. E os meandros da sociedade em que floresceram e que desvendava, com minúcia, até dela falar como se nela houvera vivido.

Cedo, porém, uma nova literatura latina, quinze séculos desfasada daquela outra, o atraiu. Não terá sido o primeiro a estudar o Humanismo português; outros, antes dele, dedicaram, de forma esparsa e avulsa, alguma atenção a essa época e aos seus autores; eram, no entanto, por via de regra, ensaios esporádicos, ocasionais. E foi ele o primeiro a dar a esse estudo uma orientação sistematizada, como quem define uma estratégia, aponta um rumo, estabelece etapas e metas. 
O Renascimento, nos seus mistérios e suas insídias, nos seus projectos e suas contradiçóes, no seu esplendor e seus obscuros meandros, nos seus enigmas e suas dúvidas, nos seus trilhos pelo mundo e suas sendas de penumbra, o Renascimento, esse tempo que foi pai e máe da modernidade que somos, era campo fértil para quem quisesse indagá-lo com e na palavra.

A sua atenção foi atraída por vultos tão variados como Gil Vicente ou André Falcão de Resende, Joana Vaz ou Diogo de Sousa. Questionou a cultura clássica do "fazedor de autos», o nosso primeiro dramaturgo, e não se coibiu de pôr em causa alguns dogmas, ainda que tivessem a assinatura de alguém com o porte intelectual e a estatura académica de Carolina Micaelis de Vasconcelos. Ponderou o seu latim tosco, analisou-o no seu contexto e provou o inteiro sentido e pertinência do seu aparente sem-sentido. A quem pensasse que o latim vicentino era feito de lugares-comuns destinados ao riso, por desajustados no tempo e no lugar, demonstrou que assim não era: o tosco daquele latim era, assim provou, aparente; olhado com atenção, revelava conhecimento e destreza no manejar da cultura antiga e deixava perceber que quem assim o utilizava era frequentador dos clássicos ou, no mínimo, dos florilégios que deles se iam fazendo.

Nunca o assustaram, em bom rigor, as verdades feitas, fosse quem fosse a autoridade que pretensamente as avalizava. Costa Ramalho sempre assim foi: íntegro, frontal, desabrido, mesmo, direito na afirmação de suas certezas e suas convicçóes, enraizadas no profundo conhecimento dos textos de que falava. 
Logo nesse tempo lhe saiu ao caminho, por um estranho acaso da Fortuna, aquele cuja companhia não mais haveria de largá-lo. Até hoje. Era ele Cataldo Parísio Sículo. O italiano bem cedo o fascinou, quando o descobriu na corte de D. João II, que para Portugal o trouxera, a mestre o destinando de D. Jorge, seu filho bastardo e projectado sucessor, posto que a mesma Fortuna (e a Rainha despeitada) lhe tivesse trocado as voltas, fazendo-o quedar-se pelo Ducado de Aveiro.

Desvendou ao humanista italiano o nome, tão obscuro quanto intrigante; retirou-lhe, mesmo, o fantasioso Áquila, com que o quiseram baptizar os que, distraídos, lhe aditaram como sobrenome o começo de um seu poema. Definiu as datas do seu magistério e da sua produção literária, assim antecipando em muitas décadas, com arrojo e contra vozes supostamente autorizadas, o nascimento do Humanismo português. Estudou-lhe e traduziu-lhe os poemas. Estudou-lhe e traduziu-lhe as cartas, fonte quase inesgotável de informaçôes preciosas para o conhecimento da política cultural do seu tempo, da sociedade em que viveu, na viragem do século, da corte em que deambulava, dos grandes que serviu, das intrigas que urdiam.

E ensinou-o. A geraçóes e geraçóes de discípulos, em quem estimulou o apreço pelos grandes vultos da cultura portuguesa renascentista e o seu estudo. Deles fez tema central de sucessivos seminários de licenciatura, depois de mestrado, quando a Universidade e seus graus iniciaram uma mutação ainda hoje inconclusa. 
Assim nasceu, da recolha dos seus trabalhos, o volume que intitulou Estudos sobre a época do Renascimento, aquele que foi o alicerce primeiro do que viria a ser o projecto de sua vida, posto que, por certo, como tal o não concebesse, ainda, nesses já longínquos anos de sessenta, com todos os contornos já bem definidos: a criação de uma escola de estudos sobre o Humanismo português do Renascimento.

Não mais conheceu parança esse percurso, nem mesmo nos dias em que escolhos, que mão alheia pelo caminho lhe interpôs, puderam (felizmente sem êxito) arrefecer-lhe o ânimo ou desviar-lhe o rumo.

A Cataldo e a André Falcáo de Resende, muitos outros nomes se foram juntando, à medida que ia desvendando os corredores escusos de Quatrocentos e de Quinhentos: João Rodrigues de Sá de Meneses, Estêvão Cavaleiro, Salvador Fernandes, Luísa Sigeia, André de Resende, Pedro Sanches, Amato Lusitano, Diogo de Teive, Aquiles Estaço, João de Barros. Estes são alguns dos objectos de trabalhos que, em 1980, viria a reunir sob o título de Estudos sobre o século XVI.

A sua precisão rigorosa ia-se apurando, esmerando, sempre no amor à palavra. É uma década, essa que medeia entre os dois livros, em que contribui para desvendar os segredos da génese da palavra Lusíadas, em que dilucida o "mal enxertado" nome (como ele mesmo lhe chama) que João de Barros deu ao seu Ropicapnefma, em que desfez o mito da idade de Joáo Rodrigues de Sá de Meneses e esse outro, o da sua precoce aura de menino génio, em que explicou o nome de Lúcio André 
de Resende. Nas linhas e entrelinhas de seus textos, filológicos, como sempre, fiéis à velha escola, era o Portugal do século de ouro que se ia desvendando, em pormenores, ora interessantes, ora pitorescos, por vezes sórdidos, sempre motivo de invulgar fascínio e não poucas surpresas.

Como qualquer universitário que se preze, prosseguia, com afinco, o seu afã de investigador, enlaçando-o no seu múnus de professor, no seu magistério. Em Coimbra, sua cidade de adopção, na sua Universidade, na sua Faculdade de Letras, os seminários que regia eram procurados com inegável avidez e subido interesse. Sob sua orientação iam saindo teses de licenciatura, teses de mestrado, teses de doutoramento, não raro convertidas, logo depois, em publicaçóes do Instituto de Estudos Clássicos ou do Centro de Estudos Clássicos e Humanísticos, documentos ainda hoje incontornáveis para quem pretenda estudar o Renascimento português e essa sua manifestação fecunda que foi o Humanismo. Pouco a pouco, um corpus de textos, repletos de novidades e semeados de novas interrogaçóes, ia dando forma a um edifício coerente, do ponto de vista científico, e promissor, do ponto de vista universitário.

A curiosidade não tinha limites. E nomes, uns mais sonantes e ilustres, outros praticamente desconhecidos, iam-lhe saindo ao caminho, para o ajudar a preencher a galeria dos Humanistas portugueses e, assim, para lhe lançarem novos reptos e desafios, que nunca enjeitava. Folheemos os quatro volumes de Para a história do 
Humanismo em Portugal, que sucederam aos dois títulos já citados, e respiguemos ao acaso: António de Cabedo, Diogo Pires, esse judeu-errante e pinga-amor, como lhe chamou Aquilino Ribeiro, não sem propriedade, mas com acentuado desconhecimento, poeta de rara valia estética entre os que em Latim compuseram nesse tempo, exilado sem regresso nem remissão, mas apegado à pátria distante; no seu encalço rumou a Dubrovnik, a velha Ragusa onde o poeta viveu as derradeiras décadas do seu degredo, esquadrinhou arquivos e documentos, comprovou as suas relaçôes locais, determinou a data provável da sua morte, ao cabo de uma vida longa, é verdade, mas bem menos longa do que a tradição lhe atribuía. Foi por suas mãos, pode dizer-se, que o poeta eborense regressou à terra natal, quase cinco séculos volvidos sobre o seu desterro forçado. A Infanta D. Maria, mecenas e exemplo de uma cultura no feminino, José de Anchieta, o missionário jesuíta, nascido espanhol (se é que assim pode dizer-se), mas feito poeta e homem de cultura em Coimbra, autor de alguns dos mais significativos testemunhos literários do primeiro Brasil, cujas gentes celebrou com cores cruentas e, porventura excessivas, quando se abalançou a cantar os feitos de Mem de Sá. E ainda Luís Pires, Diogo de Gouveia, Henrique Caiado, um dos melhores poetas bucólicos latinos do Renascimento europeu, celebrado em Itália, mas também um pouco por toda a Europa. E Inácio de Morais e Francisco de Holanda e António Luís e Pedro Sanches e Duarte de Sande, cujo Diálogo sobre a missão dos embaixadores japoneses à Cúria romana foi, 
há poucos meses, reeditado, no âmbito dos Portugalliae monumenta neolatina. Um projecto que, valha a verdade, poderá não ser seu; mas um projecto que, sem sombra de dúvida, jamais seria uma realidade se Costa Ramalho não tivesse inaugurado a escola onde, mais tarde, veio a desabrochar, como consequência e corolário natural da actividade dos que, sob sua orientação, elegeram o Humanismo como campo de estudo. E, como não podia deixar de ser, Damião de Góis, acaso o príncipe de todos eles.

Especial cuidado the mereceu Luís de Camóes, desde o dia em que questionou a palavra Lusiadas. A obra do nosso épico, fosse ela a epopeia, fosse a poesia lírica, sempre exerceu sobre o Mestre especial fascínio. De tal fascínio dão testemunho os seus Estudos Camonianos, saídos a lume em 1975 e reeditados em 1980, com profusa actualização, e o seu Camóes no seu tempo e no nosso, de 1992, que documentam a visão de um estudioso da literatura de Quinhentos, como sempre foi, mas nunca desatento aos reflexos ou réplicas, como hoje se diria, que no seu próprio tempo a iam ecoando, já em manifestaçôes de inequívoca intertextualidade, já na atenção que lhe dedicavam estudiosos e críticos, dos universos mais díspares e das mais variadas tendências. Em um e outro volume encontramos contributos preciosos e decisivos em que muito se apoiou a posterior hermenêutica do texto camoniano: a tentativa de explicação do Adamastor; a primeira interpretação consistente do mito de Actéon e da sua intrigante recorrência no poeta; a ligação da Ilha dos Amores ao 
livro VI da Eneida, de Virgílio, ao seu Inferno e aos seus Campos Elísios, que dele são a parte maior; a resposta simples para a contenda sobre as leituras platónicas de Camóes, que opusera o entáo aluno Vergílio Ferreira ao consagrado mestre Costa Pimpão, quando fez notar que bastava a leitura das Tusculanas, de Cícero, para nelas encontrar um repositório de boa parte dos conceitos platónicos do poeta. Costa Ramalho jamais adoptou como fio condutor dos seus trabalhos a hermenêutica das ideias e a especulação filosófica, filho, como sempre se assumiu, da velha escola da Filologia; mas manda a mais elementar justiça reconhecer que muito aquém teriam ficado dos resultados que alcançaram os que se aventuraram na indagação do pensamento camoniano, se não tivessem podido dispor desse manancial imenso de informaçóes que resultou dessa outra hermenêutica que foi o labor filológico deste nosso Mestre e de muitos outros como ele.

A produção bibliográfica, entretanto, ia sendo acrescentada, como se não houvera, nunca, limite para a sua capacidade empreendedora: a traduçáo do grego de Plutos ou a Riqueza, de Aristófanes (1989), de As rãs, do mesmo comediógrafo (1996) e do Diálogo dos mortos, de Luciano; a antologia de Latim renascentista em Portugal (1985); a Segunda parte das cartas e de alguns discursos de Cataldo (2005); os já referidos quatro volumes de Para a história do Humanismo em Portugal (1988 a 2000); e, já neste ano de 2010, imune à fadiga e à adversidade, a I Parte das Epistolas de Cataldo, com a colaboração de uma de suas discípulas. 
São mais de duas dezenas de livros, a par de muitas centenas de artigos, publicados em revistas universitárias de grande prestígio, em Portugal e um pouco por todo o mundo, muitos deles nos mais reputados centros de investigação internacionais na área das Humanidades.

Um mundo, no fim de contas, que calcorreou, sempre em nome da cultura portuguesa. Ensinou em Coimbra quase todas as cadeiras do velho curso de Filologia Clássica, depois chamado Línguas e Literaturas Clássicas, fossem elas de Latim ou Grego, de Literatura Grega ou de Literatura Latina, de Latim do Renascimento ou de Literatura Latina dessa mesma época. Pelo meio, passou por Lisboa, fugazmente, para logo depois retornar à sua Coimbra, em definitivo. Mas foi, igualmente, professor visitante, de 1959 a 1962, em Nova lorque, e, de 1975 a 1977, no Rio de Janeiro. Também nesses dois países foi determinante o seu contributo para o desenvolvimento dos estudos sobre o Humanismo português. Em uma e outra cidade, em um e outro país, deixou marcas, cimentou amizades, fez discípulos.

Valem, por todos, as palavras de James Hester, Presidente da New York University, no momento da partida:

"I am sure that yours is a name that will be on our lips and on our minds whenever we think of Portuguese studies and of Humanism in general in the years to come". ${ }^{1}$

${ }^{1}$ Palavras de uma carta endereçada a Américo da Costa Ramalho e por ele gentilmente cedida. 
$\mathrm{Ou}$ as do poeta Carlos Drummond de Andrade que dele diz, ao agradecer-lhe os seus Estudos camonianos, que "à segurança da documentação alia rigoroso senso de análise". ${ }^{2}$

Fiel aos princípios clássicos, ele, que era, ele próprio, um humanista, viveu a cidade. As Humanidades são inseparáveis da sua vida, são, de algum modo, parte do ar que respira: na docência universitária, na investigação, na gestão da coisa pública, na participação cívica. Tudo isso define um Humanista; e de tudo isso se fez, até hoje, a vida do Professor Costa Ramalho.

Foi deputado; percurso efémero, em boa verdade, pois que o que o animava, como bastas vezes nos disse em suas aulas, era intervir no Parlamento de então em defesa do Latim e das línguas clássicas. E assim fez. Os seus discursos em favor do ensino do Latim, pronunciados na então Assembleia Nacional, constituíram uma pedrada no charco da indiferença, já nessa altura evidente, de uma sociedade distraída em relação às nossas raízes culturais (bem menos distraída, é triste reconhecê-lo, do que a de hoje, que tende a sepultar um e outras num túmulo de perpétuo esquecimento e afadigada ignorância). Esse era o seu fito. Porque, conforme, tempos depois, confessava, de política, conhecia bem melhor a de Roma e a do Renascimento que aquela onde se digladiavam os seus contemporâneos. Porque o Latim e as línguas clássicas eram a verdadeira trincheira de todos os seus combates. Como o são, ainda, hoje, por

${ }^{2}$ Palavras de uma carta endereçada a Américo da Costa Ramalho e por ele gentilmente cedida. 
alquebradas que lhe estejam as forças. E quando, nestes dias cinzentos de ignorância, olha em volta e contempla o ambiente cultural que o rodeia e os descaminhos que, por estranha indiferença ou obsessivo desmazelo, vai levando a Educação, é a constatação desse menosprezo pelas raízes de todos nós que parece toldar-Ihe o olhar de tristeza e a voz de desalento.

$\mathrm{Na}$ Universidade, assumiu sempre, com igual denodo, as funçóes de direcção que ela lhe confiou: foi Director do Arquivo da Universidade de Coimbra, ele que sempre foi um viciado na busca minuciosa dos segredos que se escondem nas gavetas e volumes cozidos pelo tempo que esse e outros arquivos vão protegendo. Foi Director da Faculdade de Letras da mesma Universidade de Coimbra (e seja permitida uma nota de pessoal emoção, para confessar, aqui, o orgulho que tenho, seu assumido discípulo, como sou, em exercer, por mandato confiado pela minha Faculdade, as funçóes que, em outras circunstâncias, lhe foram confiadas). Foi Director do Instituto de Estudos Clássicos da Faculdade de Letras. Foi Presidente do Centro de Estudos Clássicos e Humanísticos. Foi Presidente da Associação Portuguesa de Estudos Clássicos.

Os anos quentes de 1975 e 1976 levaram-no a uma ausência voluntária no Brasil. Ingrata para com os seus mestres, a escola desse tempo parecia empenhada em subverter os valores e postergar um dos princípios que inconsistentemente apregoava: a liberdade de pensamento. Nenhuma mágoa lhe deixou esse trilho agreste, antes encontrou nele as sementes de um fecundo 
enriquecimento. E, no regresso, prosseguiu na sua dupla senda: a investigação e o magistério.

É, afinal, professor. Quando se é professor, fica-se professor para sempre. Porque jamais se deixa de ensinar. Porque os discípulos, que para sempre o serão, mesmo depois de nas carteiras velhas da velha Universidade se não sentarem já, fazem jus a esse título, um dos mais nobres que pode ambicionarse. Ora, Américo da Costa Ramalho fez escola e tem discípulos. Porque um universitário, se de primeiro quilate for, só se completa se for capaz de fazer escola. E ele fê-Ia. Com orgulho o afirmamos todos quantos dessa marca nos orgulhamos, pois sentimos por privilégio pessoal ser seus discípulos, condição que assumimos sem ambiguidades, antes como quem ostenta um pergaminho. Primeiro em dissertaçóes de licenciatura, enquanto as houve, depois em teses de mestrado, a seguir em dissertaçóes de doutoramento, foi deixando seguidores, que são, hoje, os continuadores da sua obra. Se lícito é usar aqui um paralelo com as genealogias, assim lhe foram nascendo os filhos (os discípulos directos) e, depois, os netos (discípulos de seus discípulos), pois são já vários os estudiosos do Humanismo que fizeram teses de doutoramento (para não falar das de Mestrado, que tantas são), sob orientação daqueles que em tais estudos iniciou. A sua escola tem, hoje, ramificaçóes um pouco por todo o mundo universitário português: nas Universidades de Coimbra, de Lisboa, do Porto, de Évora, de Vila Real, do Minho, de Aveiro, da Madeira, dos Açores, em mais 
do que uma universidade estrangeira - e se pecado há nesta enumeração é por omissão que não por excesso.

Continua, hoje, infatigavelmente, avesso a cansaços e a esmorecimentos, o seu projecto de vida. Mesmo depois de a vista o ter traído, nem por isso deixa de persistir em levar por diante os seus desígnios, que encara com um sentimento misto de missão e de realização pessoal. Se o famoso músico logrou compor algumas das suas mais belas sinfonias depois de atingido pela surdez, análogo é o exemplo deste Mestre de todos nós, que, praticamente privado de visão, não admite deixar a sua obra inconclusa. E sabe, de um saber profundo, que tem tanto, ainda, para descobrir, que tem tanto, ainda, para nos contar, que tem tanto, ainda, para ensinar...

Acresce que guarda consigo, incólumes, os instrumentos mais preciosos do seu fazer de artesão da ciência e da cultura: uma memória notável, que nos leva, a todos, sem excepção, a interrogá-lo, como se fora um livro aberto, sobre informaçóes, esclarecimentos, notas, datas, nomes, factos, pormenores dos mais variados, relativos aos tempos e aos autores que estudou e continua a estudar; um rigor metodológico que não cede à facilidade, irmã gémea destes tempos que são os nossos; uma integridade de carácter, que lhe exige, em cada minuto, o apego total à verdade científica.

Vem de longe já Américo da Costa Ramalho. Vem de Almeida, ali na raia, nos contrafortes da serrania, de onde as pedras espreitam a aridez e a distância; fez-se em 
Coimbra, como estudante de liceu e como estudante da Universidade; teve Mestres distintos, que sempre venerou, e outros, seus colegas no magistério, a quem sempre dedicou igual estima e que nunca lhe regatearam elogios. As palavras de Tom Earle, professor em Oxford, podem ser apresentadas como paradigmático exemplo: "de longe, a pessoa mais qualificada no mundo na área dos estudos humanísticos portugueses». ${ }^{3}$

Costa Ramalho foi, é Mestre. Teve, tem discípulos. Em Portugal e no estrangeiro. São eles o garante de que a sua obra valeu e vale a pena; são eles o garante de que a sua obra tem, náo pode deixar de ter, continuação. Sob pena de cometermos, por nossas próprias mãos, o mais tremendo de todos os assassinatos: a liquidação de nossas próprias raízes.

Fez-se Mestre, como acima se diz, em Coimbra. E foi-o aí, décadas a fio. E em Lisboa, por pouco tempo. E em quantas cidades desse mundo!

Honrou-o a comunidade científica internacional com múltiplas distinçóes: é académico de número da Academia das Ciências de Lisboa e membro efectivo da Academia Portuguesa de História, da Hispanic Society of America, da Real Academia de la Historia, em Madrid; possui a comenda da "Ordine al Merito", de Itália, obteve o Prémio Laranjo Coelho e, também, o Prémio Calouste Gulbenkian de História e Presença de Portugal no Mundo, ambos da Academia Portuguesa de História.

${ }^{3}$ Palavras de uma carta endereçada a Américo da Costa Ramalho e por ele gentilmente cedida. 
Em 1991, ditou-lhe a conjugação inexorável das leis e dos anos a retirada. Mas apenas do magistério lectivo, redundância que faz, aqui, todo o sentido. Jamais a retirada da procura. Jamais da busca incessante. Jamais do labor sem limite. Jamais, até, do próprio magistério. Um professor a sério é-o para sempre.

A Academia das Ciências de Lisboa acolheu-o, há 55 anos, em 1955, como membro correspondente, e, em 1987, como académico de número. Dessa condição sempre falou aos seus alunos com justificado orgulho. Serviu essa Academia em múltiplas missóes que ela quis confiar-lhe, assim a prestigiando e prestigiando o país e a sua comunidade científica. Refira-se, como simples exemplo, a participação no grupo que negociou, em representação de Portugal e junto dos demais países lusófonos, as bases de um novo acordo ortográfico da língua portuguesa. Muitas outras missões poderiam e deveriam ser mencionadas, se o gume inexorável do tempo não pendesse, premente, sobre estas palavras.

A mesma Academia que em 1955 o acolheu, homenageou-o, já em 2010, decorridas cerca de seis décadas e meia sobre o começo da sua vida universitária e científica. Assim lhe era reconhecido, nessa nobre reserva da cultura e da ciência, o quanto o país que somos lhe deve. Assim lhe era rendido o justo preito por quanto nos tem dado. Assim lhe era prestado tributo à sua grandeza de homem de letras e de cidadão e à sua simplicidade. Assim se lhe augurava, neste afã de que nunca desistirá, as maiores venturas. Assim se lhe agradecia, numa palavra, o quanto nos deu e o quanto nos dará. 
Vem de há muito a escalada deste homem, de seu nome Américo da Costa Ramalho. Ora dura, ora aprazível, ora por veredas escarpadas e inclementes, ora por sendas mais ligeiras e reconfortantes. Terá atingido já, presume-se, o cume ambicionado, a meta do seu peregrinar persistente, teimoso, desassossegado. Mas não o sente ele assim. Orgulha-se do caminho percorrido, talvez. Mas habita-o, nos cantos mais recônditos da sua alma de andarilho da sabedoria, a profunda convicção de que falta, ainda, um passo mais. A crença de que o cume ficará sempre um pouco mais além. É esse o fascínio que o enleia. É essa a força, estranha e mágica, de que se tece a sua persistência. É essa a grandeza da sua lição de vida, merecedora da maior gratidão. 


\section{ÍNDICE DE NOMES}

ACTÉON: 283.

AdAMASTOR: 283.

Afonso de Lucena: 125.

Afonso Henriques, D.: 258, 266.

Afonso V, D. (O Magnânimo, de Nápoles): 125, 128.

Afonso V, D.: 48, 129.

Afonso, D. (Cardeal, irmão de D. João III): 209, 221, 223.

Agostinho, Santo: 20, 32, 159.

Agrícola, Rodolfo: 35, 105, 160.

Alberti, L. B. : 109.

AlCÁCER-Quibir: 267.

Alcalá de Henares: 90, 221.

Alenquer: 220.

Alexandre VII (Papa): 254.

Alexandre, o Grande: 124, 125.

Alfonso de Cartagena: 5, 65, 67-75, 78-80, 89-91, 127.

Alfonso de Madrigal: 78.

Aljubarrota: 52, 67.

Allen, P. S. : 155, 180.

Almeida: 289.

Álvares, Fr. João: 45, 47, 129, 133.

Amato Lusitano: 280.

Anchieta, José de: 282.

Andrade, Carlos Drummond de: 286.

ANTUÉRPIA: 173, 236, 237.

Aristófanes: 276, 284.

Aristóteles: 22, 23, 32, 35, 38, 69, 72, 83, 87, 104, 108, 120, 127 , $138,143,144$.

Artes: 11, 16, 37, 86, 101, 122, 294.

Asensio: 123, 149.

Astronomia: 112, 199.

Ático: 121.

Aveiro: 39, 256, 279, 288.

Avis: 32, 59, 63, 64, 79, 89, 90, 125, 127-129.

BAÍA: 265.

BALDWIN, Charles: 29.

BARreira, João: 235, 236.

BARroco: 29, 95. 
BARros, João de: 123, 131, 133, 134, 136, 137, 140, 146, 147, 209,

212, 280.

BARTHES, Roland: 27, 41.

Basileia: 164, 165, 167, 168, 171-173, 177.

BAsílio, São: 71.

BAYET, Jean: 46-48.

BeCCADELli, António: 128.

Bernardo, São: 51, 52, 81.

BetTini, C. : 71, 89.

BLÁvio, João: 49.

Bodin, Jean: 135, 144-146, 149.

BolonHA: 24, 71, 89, 124, 172.

BORGONHA: 124, 125.

Botero, Giovani: 133, 145.

Braga: 114, 236, 244, 245.

Bragança (Dinastia e Casa): 254, 267.

Brás de Braga, Frei: 223.

BRÁsIO: 270, 271.

BRUges: 155.

Burgos: 67, 70, 77, 80, 89, 127.

Cabedo, António: 282.

Caiado, Henrique: 282.

Calado, Adelino de Almeida: 133.

Calboli: 21, 39.

Calcagnini, Celio: 170.

Camóes, Luís de: 11, 12, 13, 151, 209, 283, 284.

CAmpense, João: 222.

Caplan, H: 29.

Carlos (o Temerário): 125, 126.

Carlos Magno: 124.

Carlos V: 187.

Carvalho, Joaquim: 70, 89.

Castanheda, Fernão Lopes de: 134, 135, 147, 149.

Castela: 67, 68, 91, 92.

Castelo-Branco, Camilo: 13, 19, 39.

Castiglione, Baldassare: 140 .

Castro, Aníbal Pinto de: 253, 271.

CAstro, D. João (Governador da Índia): 147, 185, 186, 201, 202, 213.

Castro, Fernando Alvia...133, 145.

Castro, Maria Helena Lopes de: 73, 89.

Cataldo: 12, 33, 89, 279, 280, 284. 
Catarina, D. (Rainha): 229.

Cavaleiro, Estêvão: 280.

Cerejeira, Manuel Gonçalves: 222, 244.

CÉSAR: 121, 125, 126, 142.

Ceuta: 49, 53, 54, 56, 58, 61, 91, 129, 133, 202.

CHoler, Johann: 155.

Cí́cero: 5, 11, 19, 32, 36-38, 58, 59, 65, 69, 72, 74, 80, 82, 83, 86-88, 91, 96-107, 109, 114, 120-122, 126, 127, 131, 138, 139, $142,144,151,277,284$.

Ciceronianismo: 36, 37, 38.

Cintra, Luis F. Lindley: 52.

Clark, D.L: 29.

Clenardo, Nicolau: 222, 223, 244.

Cochrane, Eric: 129, 149.

Coimbra: 9, 10, 89, 140, 222, 223, 245, 246, 249-253, 258, 271, 281, 282, 285, 287, 288, 290.

Colégio das Artes: 35, 140.

COLÉGIO DE BORDÉUS: 140.

Colégio de Messina: 112.

Colégio de Sáo Clemente: 89.

Colégio de São Donaciano: 155.

ColÉGIO de SÃo Tomás: 220.

Colégio Trilingue: 168.

Colégio(s): 103, 105, 112, 113.

Colet, John: 104, 162.

Collenucio, Pandolfo: 129.

Companhia de Jesus / Jesuítas: 24, 35, 36, 38, 105, 111-114, 145 , 250, 252, 253.

CONTRA-REFORMA: 106, 144.

Correia, Gaspar: 134.

Correia, M. Alves: 122.

Correia, Tomé: 24, 38.

Costa, A.D. de Sousa: 71, 89.

Couto, Diogo do: 134, 147.

Curtius, E.: 29.

DANTE: 123.

Demétrio de Faléron: 36.

Demóstenes: 71, 83, 87, 120.

Descartes: 21.

DEVOTIO MODERNA: 63.

Dialéctica: 16, 34, 95, 101, 105, 112, 119, 134. 
Diaz, Philippe: 200.

Dionísio de Halicarnasso: 36.

Direito: 23, 28, 98, 99, 119, 124, 135, 144, 149.

DOCKHORN: 29.

Dolet, Etienne: 78.

Dorp, Martinho: 158.

DuArTe, D. (Infante, filho natural de D. João III): 187.

Duarte, D.: 47, 49, 52, 68-70, 72-80, 89, 91, 125, 127-129, 133, 135

DUMARSAIS: 26.

DupréEl, Eugene: 22.

Earle, Tom: 290.

EDUCAÇÃO: 104, 109, 125, 129, 141, 142, 177, 287.

ELOQUÊNCIA: 15, 33-38, 83, 84, 87, 93, 97-108, 113-115, 131, 139, $140,219$.

ЕрістеTO: 145.

EPISTOLOGRAFia: 119.

Erasmo de Roterdấo: 35, 95, 104, 137, 153, 155-164, 169, 171 174, 177-180, 221, 228.

EstaÇo, Aquiles: 11, 280.

EstibÁrIo, Daniel: 164.

EstrabÃo: 147.

Ética: 73, 95, 127, 142.

EugÉNIO (Papa): 81.

EURÍPIDES: 179.

Europa: 12, 16, 19, 21, 29, 35, 95, 102, 105, 111, 113, 124-126, 157, 167, 254, 263, 269, 282.

Évora: 185-187, 195, 200-206, 212, 220-224, 230, 241, 244, 253, 288.

FaCIO, Bartolomeo: 129.

FERnANDES, João: 129.

FERNANDES, Salvador: 280.

Fernández, L. Suárez: 67, 92.

Fernando, D.: 129.

Fernando, D. (Infante Santo): 45, 46, 49, 55-60, 62-64, 129, 133.

Fernấo de Oliveira: 123.

Ferrara: 167, 169.

Ferreira, Francisco Leitão: 186, 200, 212, 225, 229, 244.

Ferreira, Vergílio: 284.

Filipe III, D. (de Espanha): 264, 270.

Filipe IV, D. (de Espanha): 253.

Filipe, (o Bom, duque de Borgonha): 125. 
Filosofia: 21-28, 70, 95, 96, 101, 103, 104, 120, 122, 225, 253, 254.

FlandRES: 125, 126.

FLORENÇA: 71, 108, 126, 172.

Fonseca, Luis Adão: 79, 89.

FONTANIER: 26.

FranCIS, John: 175.

Freire, Anselmo Braamcamp: 52, 212, 219, 244.

Friedlander, Paul: 25.

Froben, João: 165, 167, 171.

Fugger, António: 164.

Fumaroli, M.,: 19, 20, 25, 26, 31, 39, 40, 41, 113, 114.

Gadamer, Hans-Georg: 25, 40.

GaLeno: 176.

Gambara, Lorenzo: 139.

GÂNDAvo, Pêro de Magalhães de: 209, 210, 212.

GARIN, E. : 29, 108, 114.

Garret, Almeida: 178.

Garrod, H.W: 155, 180.

Genette, Gerard: 26, 27, 40, 130.

Gerardo, Cornélio: 159.

Goclénio, Conrado: 222.

Góıs, Damião de: 11, 131, 132, 134, 136, 137, 283.

Goulard, Simon de: 135.

Gouveia, André de: 140.

Gouveia, Diogo de: 282.

Gramática: 33, 86, 95, 103, 142.

Gray, H: 33, 136, 150.

Gregorre, Réginald: 270, 271.

Gregório Magno, São: 32

Grimaldi (Cardeal): 169.

Guarino de Verona: 125.

Guazzo, Stefano: 107.

GuTtenberg: 21.

Hagiografia: 45, 247, 252, 270.

Halkin: 159, 180.

Henrique, D. (Cardeal Infante): 219, 221, 229, 230, 235, 241, 258, 264.

Henrique, D. (Infante): 45, 46, 49, 50, 52-59, 61-64, 129.

Hermógenes: 104.

Heródoto: 120, 136, 137, 147.

Holanda, Francisco de: 282. 
HorácIO: 38, 121, 142, 277.

Huet, Pierre Daniel: 78.

IJSSELING: 22, 39.

ÍNDIA: 134, 136, 201.

IsABel (Rainha Santa): 250, 251, 255-264, 267-271.

IsABEL, D. (filha de D. João I): 125.

Isidoro, Santo: 32.

ItÁlia: $11,21,32,36,38,70,71,90,91,105,124,126,160,165$, $168,169,282,290$.

ЈАСОВ: 231, 233, 243.

Jerónimo de Azambuja: 219-222, 225-246.

JERÓNIMO, São: 227.

JoAna, D. (Princesa): 187, 194, 214.

JoÃo (Príncipe, filho de D. João III): 187, 205.

JoÁo I, D. : 49, 52, 53, 54, 67, 69, 79, 124, 125, 129, 130, 133.

JoÁo II, D. : 32, 48, 129, 279.

JoÁo III, D. : 34, 134, 136, 140, 187, 205, 209, 220, 229, 238, 242, 253, 264, 267.

JoĀo IV, D. : 254.

JoÁo Manuel, D. (Bispo de Coimbra): 251, 271.

JoÃo V, D. : 127.

Jóvio, Paulo: 133.

Juan II, D. (de Castela): 67, 68, 125.

Júlio (Papa): 172.

KANT: 21.

Kennedy, G.: 29, 30, 41.

Kristeller, P.O.: 29, 30, 41, 95, 114, 120, 150.

La Fontaine: 19.

LABÃO: 231, 240, 243.

LAÉRCIO, Diógenes: 120.

LANCIANI, Giulia: 48.

Lanson, Gustave: 25, 26, 40.

Latim Renascentista: 9, 10, 12, 29, 151, 284.

LAURINO, João Marco: 155.

Lawrence, Green: 31, 102, 114.

LEÃo III (Papa): 167.

LEÃo, Duarte Nunes de: 196, 210, 212.

LEEMAN, A.: 21.

LEMPEREUR: 22, 39.

Leonardo Bruni: 71, 75, 78, 143.

LeONor de Aragão: 74. 
LIÂO: 237, 226, 227.

LisвoA: 147, 205, 207, 220-222, 229, 241, 253, 256, 285, 288, 290.

LONDRES: $165,167,169$.

LONGÈRE, J: 29.

LoNGINO: 36, 136.

Lopes, Fernão: 47, 52, 54, 128-130, 132, 133, 150.

Losa, Manuel: 48.

LovaINA: 38, 158, 161, 165, 167, 168, 220, 222.

LUCANO: 58, 59, 126.

Lucena, Vasco de: 89, 125, 127, 138.

LuCiano de Samósata: 120, 284.

LuÍS DA HUNGRIA: 173.

Luis, António: 282.

LUTERO: 224, 228.

MaCabeUs: 50, 52.

Macedo, Francisco de (Santo Agostinho): 252, 255, 266, 269, 270, 271.

Machado, Barbosa: 220.

Machado, Francisco: 264, 272.

MACK, Peter: 31, 41.

MADRID: 253, 290.

Manassero: 23, 39.

Manuel, D.: 132, 134, 135, 139, 238, 241, 258.

Maquiavel: 123, 143, 144.

Margolin: 157, 177, 179, 180.

MARIA, D. (Infanta): 140, 282.

Marques, João Francisco: 254, 267, 271.

Marrou, Henri-Irenée: 19-20.

MarselHa: 261.

Martin, J: 29.

Martins Marques, A. A.: 220, 227, 239, 244.

Mascagna, Rosalba:72, 91.

Matatias: 50.

Mateus, M. Helena: 126.

Matos, Luís de: 222, 244.

Mattoso, José: 119, 150.

McLuHAN: 21.

Melanchton: 112, 228.

Menéndez Pelayo, M.: 72, 90.

Meneses, D. Duarte de: 129.

Meneses, D. Pedro de : 129. 
Meneses, Garcia de: 138.

Meneses, João Rodrigues de Sá de: 280.

Menezes, Francisco de Brito de: 252.

Messina: 112.

Meyer, Michel: 22, 30.

Mighel da Arruda: 202.

Montaigne: 19, 145, 146.

Monteiro, Manuel: 252, 255, 257, 259-263, 271.

MoraIs, Inácio de: 282.

More, Tomás: 167.

Moreno Hérnandez: 71, 90.

Morrás, Maria: 69, 90.

Muret, Marc-Antoine: 24.

Murphy, James: 29, 31, 41, 102, 114.

NÁpoles: 120, 125, 128.

Nascimento, Aires: 76, 90.

Nebrija, António de: 35, 123, 133.

Neto, Serafim da Silva : 185, 191, 212.

Nicolau V (Papa): 120.

Nolhac: $120,151$.

Norden, E: 29.

Nunes, Pedro: 147.

Oecolampádio: 164.

Olbrechts-Tyteca: 22.

Oliveira, Fernando: 123, 204, 213.

Ordem de Cristo: 52, 53, 54.

Ordem dos Templários: 51, 52.

OrMUZ: 256.

Orta, Garcia de: 146, 147.

Osório, Jerónimo, D. : 11, 135, 139, 141, 146, 151, 235, 264, 272.

OuRIQUe: 258, 266, 267.

Pacheco, Diogo: 138.

Padilla, Frei Jerónimo: 200.

PÁdua: 124, 126, 167, 253, 254.

PAMACHIO: 85.

Paratore, Ettore: 48.

PARIS: 34, 38, 125, 167.

Paulo, São: 163.

PAVIa : 124.

Pedro, D. (Infante): 69, 71, 72, 90, 92, 126-129.

Pereira, D. Nun'Álvares: 133. 
Pereira, Duarte Pacheco: 147.

Pereira, Isaías da Rosa: 224, 244.

Pereira, Virgínia Soares: 194, 213, 217, 234, 245.

Perelman, Chaim: 22, 23, 24, 39, 40.

Pérez Priego, M.: 68, 91.

Petrarca: 109, 120-122, 134.

Piccolomini, Alexandre: 107.

Piccolomini, Enea Silvio: 107.

Pimpão, Costa: 284.

Pina, Rui de: 45, 47, 48, 129, 133, 135.

PÍNDARO: 25.

Pinheiro, António: 35.

Pinho, Sebastião Tavares de: 183, 188, 209, 213, 224, 245.

Pinto, Fernão Mendes: 146.

Pires, Diogo: 11, 282.

Pires, Luis: 282.

Pisano, Mateus de: 49, 53, 138.

Pita, Isabel Beceiro: 69.

Pitágoras: 163.

Platão: 21, 144, 163.

Plutarco: 120, 125, 127, 144, 176, 293, 294.

Poesia: 26, 103, 109, 120, 138, 139, 142, 247, 249, 251, 252, 283, 293.

Pole, Ricardo : 170.

Políbio: 120, 143, 144.

Política: 12, 15, 23, 28, 29, 34, 57, 65, 67, 68, 69, 83, 89, 95, 96, $97,100,104,108,114,124,127,128,135,140,143,144,148$, 149, 151, 157, 219, 222, 247, 263, 269, 279, 286.

Poliziano: 38, 138, 142.

PoMpeu: 124.

Pompónio Mela: 147.

Pontano, Giovanni: 120.

Porto: 256, 288.

Portugal: $11-13,16,31-32,35,37-38,52,54,67-73,78-79,89$, 91-92, 115, 124-127 133, 135, 139, 141, 145, 149-151, 187, 204, 213, 220-222, 242, 244-245, 249-52, 254, 258-260, 262, 265-266, 270-271, 275, 279, 281-285, 290-291.

Probatio: 58, 60.

Proust, Marcel: 178.

Pulgar, Fernando del: 68, 91.

QueIrós, Eça de: 157.

Quevedo, Bartolomeu de: 194, 213, 234. 
Quintiliano: 20, 32, 33, 35, 37, 104, 109, 110, 127, 138-139.

Ragusa (Dubrovnik): 282.

Ramalho, Américo da Costa: 7, 9, 10, 12, 33, 138, 148, 151, 273,

275, 278, 283-286, 288, 289, 290, 292.

RAMÉE: 24, 105.

RAMISMO: 24, 26.

RAU, V.: 71, 91.

ReForma: 96, 106, 111, 144, 223, 244.

Rego, Raul: 220, 245.

Regras, João das: 124.

ReIs, António dos: 252, 255, 257, 259-263, 271.

Religiấo: 23, 104, 159, 163, 169, 241, 265.

Renano, Beato: 170.

Renascimento: 11-12, 15, 17, 24, 29, 30-31, 37-38, 93, 95- 97, 101 103, 105-109, 111, 113, 115, 120, 122, 125, 128, 130, 140, 147, 208, 244, 275, 277, 278, 280-282, 285, 286, 294.

RÉsCIO, Rogério: 222.

Resende, André de: 5, 11, 35, 123, 168, 183, 185-187, 189-201, 203-

210, 213-214, 217, 219, 221-225, 229-233, 235, 237-239, 241,

242, 244, 245, 280, 281.

Resende, André Falcão de: 278, 280.

Restauração: 247, 249, 251-253, 255, 257, 265, 271.

Retórica: 15, 16, 17, 19-41, 58, 60, 80, 93, 95-97, 99, 101-115, $120,138-139,140,147,150,152,158,174,179,230,253,269$, 270-271, 294.

ReUCHLIN: 168.

RiáRIO (Cardeal) : 168.

Ribeiro, Aquilino: 282.

Ribeiro, Ilídio de Sousa : 253, 271.

RINCK: 178.

RINGELBERG, Joachim: 35.

Rocha Madail: 251, 271.

RODRIGUES, Luís: 212, 245.

Rodrigues, Manuel Augusto: 220, 222, 227, 228, 230, 236, 237, 245.

Rolán, T. González: 65, 71, 75, 90, 127.

Roma: 24, 38, 121, 123, 126, 141, 144.

RucQuoI, Adeline: 71, 91.

SÁ, Mem de: 282.

Sagrada Escritura: 224, 225, 239, 245.

Salazar, Abdón: 70, 73, 74, 91.

SAlústio: 48, 83, 126, 142. 
Salutati, Coluccio: 109, 121.

SAlVAdor (Brasil): 256.

SANChes, Pedro: 280, 282.

Sanctes Pagnino O.P. : 226, 235, 237.

SANDE, Duarte de: 12, 282.

SANTARÉm: 253.

Saquero Suárez, A: 71, 90.

Saraiva, J. Hermano: 63.

Schets, Erasmo (consultor financeiro de Erasmo de Roterdáo): 166, 173.

ScheTs, Gaspar: 173.

Sebastiấ, D.: 186, 236, 255, 258, 259, 264, 267, 268.

SeIgel, J: 30.

SÉneCA: 58, 59, 69.

Servais, Rogério: 159, 160, 163.

SiENA: 124.

Sigeia, Luisa: 280.

Silva, D. Miguel da: 11, 140.

SoAres, Nair de Nazaré: 71, 92.

SólOn: 163.

Somonte, P.: 71, 90.

STEIner, George: 78, 92.

Struever, N: 30.

STURM, João: 105.

SuEtónio: 121, 126.

TÁciтo: 48, 121, 144, 145.

TAINE: 25, 26.

TÂnger: 45, 46, 58.

Tavani, Giuseppe: 48.

Terve, Diogo de: 136, 141, 280.

Teologia: 28, 162, 221, 222, 225, 241, 253, 254.

TÉSIFO: $71,87$.

Tito Lívio: 46, 120, 121, 132, 137, 142, 144.

Tolentino, Nicolau: 19.

TournaI, João Vitrier de: 161.

TREBIZONDA: 35 .

Trento: 220, 228.

Tubingen: 112.

Tucídides: 120, 130, 136, 147.

TYTeCA: 22, 23.

UlLmanN, Walter: 119, 152. 
UNIVERSIDADE: 9, 28, 30, 103, 112, 124, 125, 126.

VAlÉrio Máximo: 121.

VALLA, Lorenzo: 33, 89, 123, 134, 228.

VASEU, João: 35.

VAsOLI, C.: 24, 29, 40.

Veneza: 126, 167, 169, 253, 254.

VERDELHO: 21, 39.

Vergerio, Pier Paolo: 14, 121, 126, 127.

VERONA: 121.

Viana do Alentejo: 201.

Viana do Castelo: 236.

VICENTE, Gil: 12, 278.

VICENTE, São: 207.

VICKERS: 107-110, 112, 115.

Victor Hugo: 25, 26.

VIEIRA, António: 106.

Virgílio: 58, 59, 121, 137, 142, 277, 284.

Visconti, Giangaleazzo: 108.

Vives, J. L: 105, 109, 145, 146.

Volkmann, R: 29.

Weinberg, B: 29, 139, 152.

Xavier de Maistre: 178.

Xenofonte: $120,143,144$.

Zamora, Juan Alfonso de: 67, 69, 77.

Zurara: 47, 49, 54, 89, 129, 133.

ZURIQUE: 155. 


\section{COLECÇÃo AUtores \\ GREgos E LATINos - SÉrIe ENSAIOS}

1. Carmen Soares, José Ribeiro Ferreira e Maria do Céu Fialho: Ética e Paideia em Plutarco (Coimbra, $\mathrm{CECH}, 2008)$.

2. Joaquim Pinheiro, José Ribeiro Ferreira, Nair Castro Soares, Rita Marnoto: Caminhos de Plutarco na Europa (Coimbra, CECH, 2011). 2a edição, revista e com um novo estudo.

3. Cláudia Teixeira, Delfim F. Leão and Paulo Sérgio Ferreira: The Satyricon of Petronius: Genre, Wandering and Style (Coimbra, CECH, 2008).

4. Teresa Carvalho, Carlos A. Martins de Jesus: Fragmentos de um Fascinio. Sete ensaios sobre a poesia de José Jorge Letria (Coimbra, CECH, 2009).

5. Delfim Ferreira Leão, José Ribeiro Ferreira e Maria do Céu Fialho: Cidadania e Paideia na Grécia Antiga (Coimbra, CECH, 2010).

6. Maria de Fátima Silva and Susana Hora Marques: Tragic Heroines on Ancient and Modern Stage (Coimbra, $\mathrm{CECH}, 2010)$.

7. Ália Rosa Rodrigues, Carlos A. Martins de Jesus, Rodolfo Lopes: Intervenientes, Discussão e Entretenimento, No Banquete de Plutarco (Coimbra, CECH, 2010). 
8. Luísa de Nazaré Ferreira, Paulo Simóes Rodrigues e Nuno Simóes Rodrigues: Plutarco e as Artes. Pintura, Cinema e Artes Decorativas (Coimbra, CECH, 2010).

9. Nair Castro Soares, Margarida Miranda, Carlota Miranda Urbano (Coord.): Homo eloquens homo politicus. A retórica e a construçáo da cidade na Idade Média e no Renascimento (Coimbra, CECH, 2011). 
IMPRESSÃO:

Simốes \& Linhares, Lda.

Av. Fernando Namora, n. ${ }^{\circ} 83$ - Loja 4

3000 CoImbra 
Com o advento do Humanismo, uma nova cultura é inaugurada, em que o homo sapiens se torna indissociável do homo eloquens e do homo politicus. À Cidade e à constituição dos laços sociais estão directamente associados os studia humanitatis, em que ganham especial relevo os estudos de Retórica, não a Retórica reduzida ao puro exercício técnico e formal, mas uma Retórica que, sendo tão inseparável da dialéctica quanto da realidade, é entendida como instrumento prático e útil, nos domínios político, jurídico, religioso, moral e pedagógico.

O conjunto dos estudos que apresentamos neste volume reflecte esses nexos entre homo sapiens, homo eloquens e homo politicus e as suas múltiplas expressóes, em Portugal e na Europa.

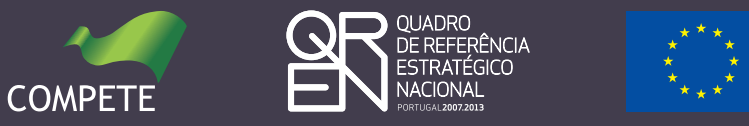

